CASTRO, R. C. G. Negatividade e participação: a influência do Pseudo Dionísio Areopagita em Tomás de Aquino - teologia, filosofia e educação. Tese apresentada à Faculdade de Educação da Universidade de São Paulo (USP) para obtenção do título de Doutor em Educação.

Aprovado em:

Banca Examinadora

Prof. Dr. Luiz Jean Lauand (orientador)

Faculdade de Educação da USP

Prof $^{a}$ Dr $^{a}$ Aida Ramezá Hanania

Faculdade de Filosofia, Letras e Ciências Humanas da USP

Prof. Dr. Marcos Ferreira dos Santos

Faculdade de Educação da USP

Prof. Dr. Mario Bruno Sproviero

Faculdade de Filosofia, Letras e Ciências Humanas da USP

Prof. Dr. Sylvio Roque de Guimarães Horta

Faculdade de Filosofia, Letras e Ciências Humanas da USP 
ROBERTO CARLOS GOMES DE CASTRO

Negatividade e participação: a influência do Pseudo Dionísio Areopagita em Tomás de Aquino - teologia, filosofia e educação

Tese apresentada à Faculdade de Educação da Universidade de São Paulo (USP) para obtenção do título de Doutor em Educação

Área de Concentração:

Filosofia da Educação

Orientador:

Prof. Dr. Luiz Jean Lauand

SÃO PAULO 
Autorizo a reprodução e divulgação total ou parcial deste trabalho, por qualquer meio convencional ou eletrônico, para fins de estudo e pesquisa, desde que citada a fonte.

Catalogação na Publicação

Serviço de Biblioteca e Documentação

Faculdade de Educação da Universidade de São Paulo

37.01 Castro, Roberto Carlos Gomes de

C355n Negatividade e participação: a influência do Pseudo Dionísio Areopagita em Tomás de Aquino - teologia, filosofia e educação/Roberto Carlos Gomes de Castro; orientação: Luiz Jean Lauand. São Paulo: s.n., 2009.

$192 \mathrm{p}$.

Tese (Doutorado - Programa de Pós-Graduação em Educação. Área de Concentração: Filosofia da Educação) - Faculdade de Educação da Universidade de São Paulo.

1. Areopagita, Pseudo Dionísio 2. Tomás de Aquino, 1225?-1274 3. Filosofia da educação 4. Teologia 5. Filosofia medieval I. Lauand, Luiz Jean, orient. 
Para a Natália e o Jonathas, minhas grandes alegrias.

Para o José Orlando (in memoriam), orgulho de todos nós. 


\section{SUMÁRIO}

APRESENTAÇÃ

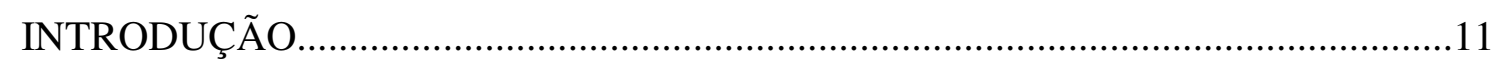

PARTE I: O PSEUDO DIONÍSIO AREOPAGITA

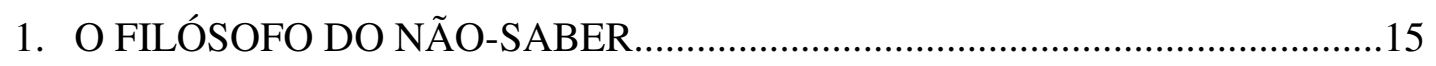

2. DO CRISTIANISMO MEDIEVAL À TEOLOGIA CONTEMPORÂNEA.......39

3. NEGATIVIDADE E PARTICIPAÇÃO NO CORPUS DIONYSIACUM............47 PARTE II: TOMÁS DE AQUINO

4. TOMÁS LEITOR DE DIONÍSIO..................................................................61

5. O PENSAMENTO NEGATIVO DE TOMÁS DE AQUINO..............................71

6. O CONCEITO TOMASIANO DE PARTICIPAÇÃO........................................99

7. DA METÁFORA COMO FONTE DO CONHECIMENTO............................129

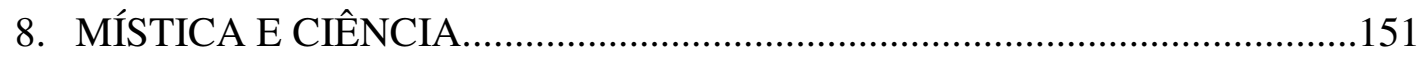

CONCLUSÃO

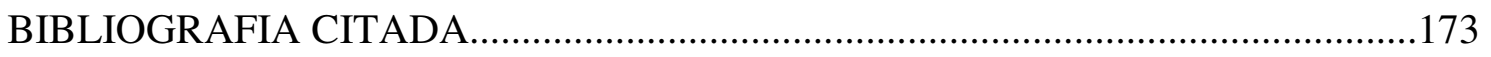

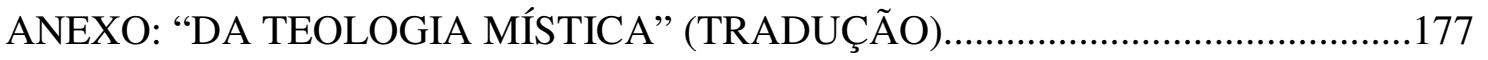

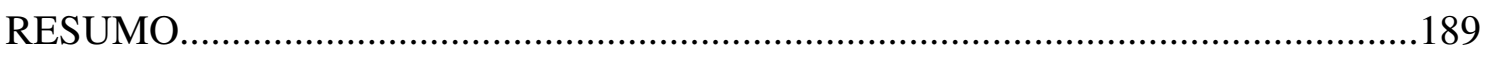

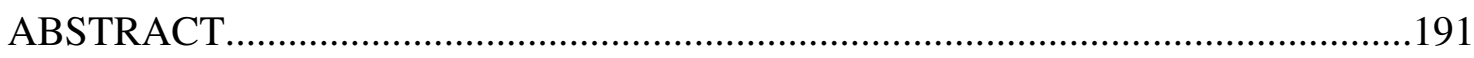




\section{APRESENTAÇÃ̃O}

O teólogo conhecido como Pseudo Dionísio Areopagita tinha três olhos e morava numa terra de cegos, na feliz e bem-humorada expressão do professor Jean Lauand $^{1}$. De fato, o grande pensador do final do século $\mathrm{V}$ e início do século VI, que viveu provavelmente na região onde hoje se localiza a Síria, dificilmente encontraria, naquela época, um interlocutor da sua estatura intelectual. No Oriente já havia passado o esplendor da primeira Patrística, e o Ocidente estava instalado nas trevas dos reinos bárbaros.

$\mathrm{O}$ ano de 529 assistiu a dois acontecimentos cruciais, que definiriam o desenvolvimento do Ocidente nos séculos seguintes: o fechamento da Academia de Platão, em Atenas, pelo imperador bizantino Justiniano, e a fundação do Mosteiro de Montecassino, por São Bento. De um lado, o império cristão cerra definitivamente a fonte do paganismo platônico. De outro, tem início um movimento que será responsável pela educação de toda a cristandade medieval e, curiosamente, preservará - através do trabalho dos copistas nos mosteiros - não só as escrituras cristãs, mas também obras dos grandes pensadores e escritores da Antiguidade.

É também em torno da década de 520 que surgem os livros do Pseudo Dionísio Areopagita. Um pensador cristão fascinado pelo pensamento neoplatônico, graças a ele conceitos herdados de Platão - como a doutrina das ideias -, adaptados de acordo com a doutrina cristã, serão preservados ao longo da Idade Média. Mais do que isso, Dionísio dá uma contribuição inestimável à teologia e à filosofia ao desenvolver temas de aguda profundidade, entre eles a radical transcendência de Deus, o mundo como manifestação do divino, a hierarquia dos anjos, o mistério oculto na liturgia cristã, a insuficiência da linguagem humana, os limites e possibilidades da razão e a forma de acesso possível às realidades espirituais, entre vários outros. Com isso, o pensamento de Dionísio marcará profundamente os pensadores medievais - incluindo o maior deles, Tomás de Aquino.

Este trabalho tem justamente o objetivo de investigar o pensamento e a influência do Pseudo Dionísio Areopagita, tão pouco conhecidos no Brasil. Ele está dividido em duas partes. Na primeira, discute a identidade de Dionísio - até hoje motivo

\footnotetext{
${ }^{1}$ A expressão foi usada em 2005, ao sugerir-me esse tema de tese de doutorado. É, portanto, o marco inicial deste trabalho.
} 
de dúvidas e controvérsias -, mostra as influências neoplatônicas e cristãs que estão na base de sua obra e analisa os quatro tratados - Da hierarquia celeste, Da hierarquia eclesiástica, Dos nomes divinos e Da teologia mística - e as dez cartas de sua autoria. Aponta ainda a importância de Dionísio para os autores medievais e termina com um estudo sobre dois conceitos especialmente importantes para a teologia e a filosofia de Dionísio: negatividade e participação.

Na segunda parte, é dado destaque para a influência de Dionísio sobre Tomás de Aquino. Precisamente os conceitos de negatividade e participação serão decisivos na teologia e na filosofia do Aquinate, dotando-as de um caráter negativo - ou seja, ciente da incognoscibilidade das coisas mais profundas - que, se não for reconhecido, deturpase inevitavelmente o pensamento de Tomás. Ainda nessa segunda parte deste trabalho, o estudo intitulado "Tomás leitor de Dionísio" aborda principalmente a forma como o Aquinate assimilou a obra dionisiana, "corrigindo-a" em alguns aspectos importantes entre eles, a Criação como vontade divina, a questão do mal e o ser de Deus. Com isso, supomos que Tomás tenha "livrado" Dionísio do "excesso" de neoplatonismo que sua teologia pudesse conter - e que tantas críticas gerou ao longo dos séculos, como a do reformador Martin Lutero, para quem o autor de Dos nomes divinos "mais platoniza do que cristianiza".

Este trabalho que não seria possível sem a orientação do professor Jean Lauand, a quem agradeço profundamente pela dedicação, excelência e generosidade com que exerce seu magistério.

É muito fácil justificar por que dedico este trabalho à Natália, ao Jonathas e ao José Orlando. Natália e Jonathas, minha esposa e filho, são, como está na epígrafe, minhas grandes alegrias. É um prazer imenso estar sempre ao lado deles. José Orlando é meu irmão, que nos deixou precocemente. Engenheiro brilhante, formado pela Escola de Engenharia de São Carlos da USP, teve uma vida maravilhosa, que nos enche de orgulho e de alegria só de pensar. Ser seu irmão é uma grande inspiração.

Finalmente, agradeço a meus pais, Orlando de Castro e Marlene Gomes da Costa Castro. Os dois são fantásticos, maravilhosos, imprescindíveis.

São Paulo, 11 de outubro de 2009 Roberto Carlos Gomes de Castro 


\section{INTRODUÇÃO}

O teólogo e filósofo medieval Tomás de Aquino (1225-1274) é um dos tantos pensadores que tiveram seu pensamento deturpado ao longo dos séculos. Já a partir de seus primeiros intérpretes, a obra do Aquinate por vezes tem sido transformada sobretudo quando se trata de apresentá-la escolarmente num ensino oficial, "ad mentem divi Thomae" - numa coleção de máximas racionalistas, de ordenanças, de mandamentos e de certezas absolutas. Na visão que se criou, o mestre de Aquino se assemelha a um pensador radical, convicto da veracidade de suas reflexões e detentor de respostas para todos os problemas do homem e da sociedade.

Em geral, basta abrir um manual tomista tradicional para se deparar com esse perfil do mais original e profundo pensador da Idade Média. Tome-se, por exemplo, Tomismo hoje, de Fernando Arruda Campos². Ali encontra-se a afirmação de que a síntese entre aristotelismo e agostinianismo feita por Tomás se deu a partir de um princípio fundamental: "a inteligibilidade radical do ser, à luz do qual tudo se torna inteligível e no qual tudo encontra sua verdadeira e radical explicação"3.

Tomás jamais teve a pretensão de "explicar tudo". Exatamente ao contrário, ele conhecia os limites da razão humana e a insuperável distância existente entre ela e a ciência mais profunda das coisas, envoltas inapelavelmente no mistério. Citemos algumas afirmações do Aquinate, o suficiente para mostrar que ele não se identifica com o tomismo tradicional:
As essências das coisas nos são desconhecidas. ${ }^{4}$
Os princípios essenciais das coisas nos são ignorados. ${ }^{5}$

Este é o máximo grau de conhecimento humano de Deus: saber que não o conhecemos. $^{6}$

Nenhum filósofo pode conhecer perfeitamente a natureza de uma mosca sequer. ${ }^{7}$

\footnotetext{
${ }^{2}$ Fernando Arruda Campos, Tomismo hoje. São Paulo: Loyola, 1989.

${ }^{3}$ Fernando Arruda Campos, obra citada, p. 18-19.

${ }_{5}^{4}$ Questão disputada sobre a verdade $10,1$.

${ }^{5}$ In de anima $1,1,15$.

${ }^{6}$ Questão disputada sobre a potência de Deus 7, 5, ad 14.

${ }^{7}$ Comentário ao Credo dos Apóstolos, prólogo.
} 
Esse reconhecimento da incognoscibilidade das coisas - que elimina qualquer traço de clareza absoluta no pensamento tomasiano - remete à obra do teólogo cristão conhecido como Pseudo Dionísio Areopagita. Dionísio enfatiza a radical transcendência de Deus, que, como criador de todas as coisas, conserva em si a essência de tudo o que existe - daí a impossibilidade do intelecto humano de abarcar o conhecimento mais profundo da existência.

A influência de Dionísio sobre Tomás muitas vezes passou despercebida para muitos intérpretes do pensamento do Aquinate, que sempre apontaram nele as marcas de Aristóteles e de Santo Agostinho, mas ignoraram a importância da obra dionisiana. Porém, é justamente a contribuição do autor de Dos nomes divinos que confere à teologia do mestre de Aquino o elemento negativo, a consciência da incognoscibilidade das coisas e a humilde convicção dos limites da razão humana. Pode-se supor, assim, que foi graças a Dionísio que Tomás não caiu na tendência racionalista da teologia medieval - na medida em que cabe falar de "racionalismo" em pensadores medievais -, que seduziu grandes pensadores, como Boécio e Anselmo de Canterbury.

Essa influência de Dionísio sobre Tomás, principalmente no que se refere a dois aspectos fundamentais do pensamento do Aquinate - a negatividade e a participação - é analisada nas páginas a seguir. 
PARTE I: O PSEUDO DIONÍSIO AREOPAGITA 


\section{O FILÓSOFO DO NÃO-SABER}

Por volta do ano 50, o apóstolo Paulo - o incansável missionário que introduziu o cristianismo entre os gentios - chegou a Atenas, na Grécia, na segunda de suas famosas viagens missionárias. Ali, foi convidado a discursar no Areópago, uma das instituições mais tradicionais da cidade ${ }^{8}$, conforme registra Atos dos apóstolos ${ }^{9}$, um dos livros do Novo Testamento.

Em seu discurso, Paulo adotou uma atitude de conciliação com a filosofia, bem diferente da postura que assumiria poucos anos mais tarde, ao escrever sua primeira carta à igreja de Corinto, na qual chama a sabedoria humana de "loucura"10. Longe de criticar o pensamento e a cultura, Paulo chega até mesmo a usar textos da literatura grega ao falar aos membros do Areópago, os areopagitas. "Pois nele vivemos, nos movemos e existimos, como também alguns dos vossos poetas disseram: 'Pois dele também somos progênie" ${ }^{, 11}$, disse, citando um verso que lembra obras de Arato $^{12}$ e de Cleanto $^{13}$.

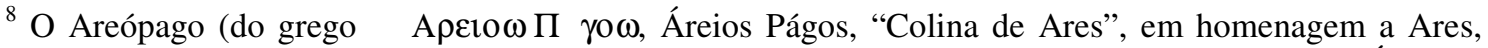
deus da guerra) foi instituído em tempos imemoriais, segundo a mitologia, pela deusa Athena (Ésquilo, Eumênides, 681). Era o principal órgão de governo de Atenas nos regimes aristocrático e oligárquico, funcionando como corte de justiça e conselho político. Com as reformas democráticas de Efialtes, em 462

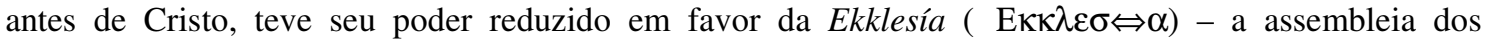
cidadãos - e dos tribunais populares e passou a exercer somente funções judiciárias. No século I depois de Cristo, com a Grécia dominada pelo Império Romano, tinha apenas caráter figurativo (A. Jardé, $A$ Grécia antiga e a vida grega, São Paulo, EPU/Edusp, 1977, p. 191, e Peter V. Jones, O mundo de Atenas, São Paulo, Martins Fontes, 1997, p. 213-215).

${ }^{9}$ Atos dos apóstolos 17:16-34.

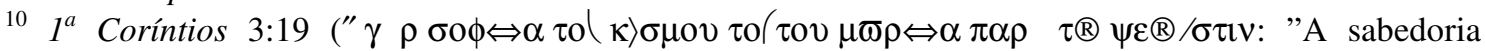
deste mundo é loucura para Deus"). Os textos do Novo Testamento citados neste trabalho foram traduzidos do original grego publicado em The greek New Testament, editado por Kurt Aland e outros, $3^{\mathrm{a}}$ edição, Münster, United Bible Societies, 1975. A tradução é nossa.

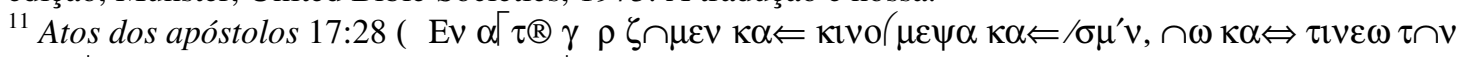

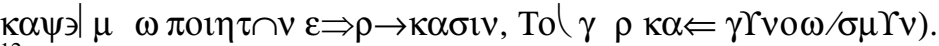

${ }^{12}$ Em Fenômenos 1-5, Arato (315-240 antes de Cristo) afirma: "'Por Zeus comecemos/ Nunca nós, homens, amemos o que não é dito./ Todos os caminhos estão cheios de Zeus,/ Todas as praças dos homens,/ O mar está cheio e os portos;/ Todos nos servimos de Zeus em tudo./ Pois dele também somos

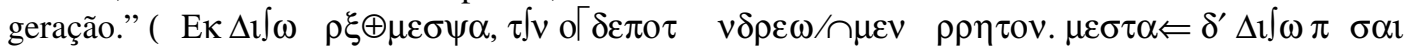

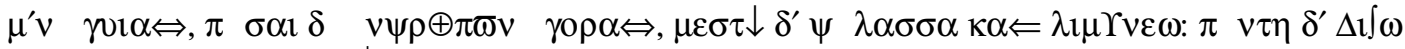
$\kappa \varepsilon \xi \rho \rightarrow \mu \varepsilon \psi \alpha \pi \quad v \tau \varepsilon \omega . \tau o(\gamma \rho \kappa \alpha \Leftarrow \gamma \Upsilon \gamma \nu \circ \omega \varepsilon \Rightarrow \mu \curlyvee v$.).

${ }^{13}$ Em Hino a Zeus, Cleanto (331-232 antes de Cristo) canta: "Adorado com mil sagrados nomes/ Suprema divindade onipotente/ Autor da natureza, a cujo aceno/ E poder sem limites tudo cede/ Zeus majestoso, salve, salve/ A ti só te é devido o humilde rogo/ E o canto dos mortais que tu criaste/ De ti viemos nós, de ti tiramos/ Nossa fraca existência, ó, Deus eterno./ O que vive e se move é obra tua,/
} 
Desse verso, que com sensibilidade celebra a profunda ligação do ser humano e de todas as coisas criadas com seu ponto de origem - o Criador -, Paulo extrai uma conclusão lógica, bem ao gosto dos seus ouvintes, versados na filosofia grega: "Portanto, sendo geração de Deus, não devemos pensar ser o divino semelhante ao ouro ou à prata ou à pedra, símbolos da arte e da reflexão do homem"14.

Para Paulo, a divindade não se parece com nada do que o homem vê ou conhece, mas transcende toda capacidade de compreensão. Referindo-se ao Altar do Deus Desconhecido, que os atenienses haviam erigido numa de suas praças, o apóstolo disse que o objeto de suas pregações era exatamente esse ser inescrutável e inatingível, inefável e inesgotável, tão elevado a ponto de não poder ser concebido pela mente do homem. "O que temeis não conhecendo, esse eu vos anuncio.",15

O discurso gerou reações distintas. Entre os ouvintes, uns se desinteressaram pelo assunto, enquanto outros chegaram a escarnecer do apóstolo. Mas nem todos desprezaram a mensagem de Paulo. O livro de Atos dos apóstolos registra textualmente: "Mas alguns homens, unindo-se a ele, creram, entre os quais também Dionísio, o Areopagita, uma mulher com nome Damaris e outros com eles"16.

Essa referência a "Dionísio, o Areopagita", que poderia ter passado quase despercebida, teria vastas consequências na história. Sob esse nome, surgiu no início do século VI um conjunto de obras - quatro tratados e dez cartas - que, ao longo dos mil anos seguintes, exerceria profunda influência na teologia e na filosofia. Os quatro tratados são intitulados Da hierarquia celeste, Da hierarquia eclesiástica, Dos nomes divinos e Da teologia mística ${ }^{17}$.

Encorpadas porções da alma divina/ Meu rouco canto pois a ti consagro/ Teu poder espantoso celebrando."

$\mathrm{K} / \delta 1 \omega \quad \psi \alpha \nu \quad \tau \varpi v, \pi 0 \lambda v \oplus v v \mu \varepsilon, \pi \alpha \gamma \alpha \rho \alpha \tau^{\prime} \omega \alpha \Rightarrow \varepsilon \models / Z \varepsilon l, \phi\left(\sigma \varepsilon \varpi \omega \quad \rho \xi \eta \gamma^{\prime}, v\right\rangle \mu \varepsilon \mu \Upsilon \tau \alpha \pi \quad v \tau \alpha$

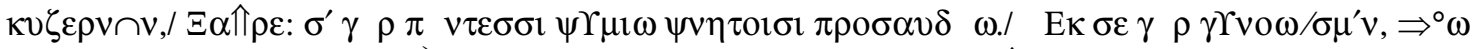

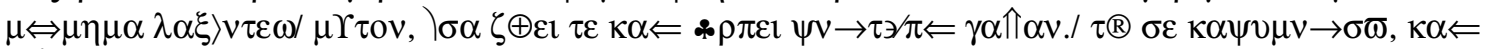
$\sigma \int_{V}$

$\left.\kappa \rho \quad \tau O \omega \quad \imath^{\prime} \mathrm{v} \quad \varepsilon \Leftrightarrow \sigma \sigma\right)$.

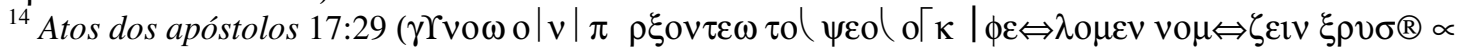

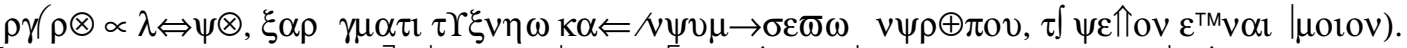

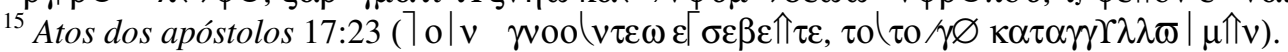

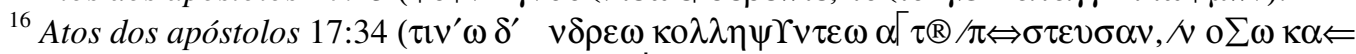

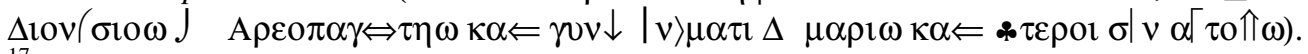

${ }^{17}$ Ao longo de sua obra, o Pseudo Dionísio Areopagita cita outros sete livros como sendo de sua autoria. São eles: $O$ inteligível e o sensível, Das propriedades e ordens dos anjos, Da alma, Do justo juízo de Deus, Das representações teológicas, Hinos divinos e Teologia simbólica. Como nunca foram citados por outros autores e não se conhece nenhum fragmento desses textos, supõe-se que, provavelmente, eles são fictícios, não passando de mais uma criativa simulação do autor do Corpus Dionysiacum. 
Dúvidas quanto à autenticidade desses escritos surgiram já quando eles se tornaram conhecidos, em 533, durante uma conferência teológica realizada em Constantinopla. Convocado pelo imperador bizantino Justiniano, esse evento tinha como objetivo resolver uma velha disputa a respeito da pessoa de Jesus Cristo, que dividia o cristianismo em dois grupos de teólogos: os ortodoxos, que defendiam ser Cristo dotado de duas naturezas - uma divina e uma humana -, e os "monofisitas"18, que viam o fundador da religião cristã com uma única natureza, a divina.

Em meio aos debates, os monofisitas apresentaram os textos de Dionísio, o Areopagita, para sustentar suas teses. Mas foram contestados por Hipácio de Éfeso, que questionou o valor das obras, lembrando que elas nunca haviam sido citadas pelos Pais da Igreja ao longo dos séculos anteriores.

Apesar da dúvida instalada por Hipácio, os quatro tratados e as dez cartas se difundiram pela cristandade com a autoridade quase canônica de ter como autor o membro do Areópago convertido ao Evangelho através do discurso de Paulo. Com essa fama, o Corpus dionysiacum moldou boa parte do cristianismo medieval, no que se refere tanto às práticas litúrgicas da Igreja $^{19}$ como ao pensamento teológico ${ }^{20}$. No século IX, a equivocada atribuição do Corpus a Dionísio (210-258), bispo mártir de Paris - feita por Hilduíno, dirigente da abadia de Saint Denys, em Paris, na sua obra Passio sanctissimi Dionysii -, só fez aumentar a confusão sobre o verdadeiro autor dos tratados.

Foi somente durante o chamado Renascimento que a autoria das obras até então atribuídas a Dionísio, o Areopagita, começou a sofrer crítica mais apurada. Esta foi feita inicialmente pelo humanista italiano Lourenço Valla (1407-1457), ao mesmo tempo em que o cardeal alemão Nicolau de Cusa (1401-1464), em seus escritos, levantava as mesmas suspeitas. Numa conferência intitulada Encomium sancti Thomae Aquinatis, realizada em Roma em 1457, Valla classificou Dionísio como um dos "príncipes da teologia", mas ressalvou que ele não fora citado por nenhum autor grego ou latino antes de Gregório Magno (cerca de 540-604) ${ }^{21}$. Influenciado por Valla, o humanista inglês

\footnotetext{
${ }^{18}$ Do grego $\mu>$ vow (mónos, único) e $\phi(\sigma \iota \varphi$ (fýsis, natureza).

19 Por exemplo, a doutrina católica dos anjos, o uso de imagens e a mística dos rituais são claras influências da teologia do Pseudo Dionísio Areopagita na liturgia da Igreja, embora muitas vezes isso sequer seja percebido.

20 A influência do Pseudo Dionísio Areopagita sobre a teologia medieval é o tema do capítulo 2 da primeira parte deste trabalho.

${ }^{21}$ Citado por Teodoro H. Martin em Obras completas del Pseudo Dionisio Areopagita, Biblioteca de Autores Cristianos, Madrid, 1990, página 51.
} 
William Grocyn (1446-1519) declarou, em palestras sobre Da hierarquia eclesiástica, proferidas em 1501, que não mais admitia a autoridade de Dionísio, o Areopagita.

Mas as observações de Valla permaneceram inéditas até que, em 1505, o teólogo holandês Erasmo de Roterdã (1466-1536) publicou as Adnotationes do humanista italiano ao Novo Testamento, que incluíam suas dúvidas sobre a autoria do Corpus dionysiacum. "Em consequência, foi Erasmo quem 'atirou a primeira pedra", afirma T. H. Martin, citando frase do alemão J. Stiglmayr ${ }^{22}$.

Desde então, os críticos acumularam cada vez mais evidências de que os quatro tratados e as dez cartas, de tão larga influência na história da Igreja, não poderiam ser obra do cristão convertido pelo apóstolo Paulo. Nos séculos XVI e XVII, esse trabalho coube principalmente a teólogos protestantes, como o francês Jean Daillé (1594-1670). No final do século XIX, graças a pesquisas feitas por J. G. Engelhardt, F. Creuzen, H. Koch e J. Stiglmayr, já se sabia que o Corpus dionysiacum não era obra de Dionísio, o Areopagita, embora não fosse possível conhecer a identidade do verdadeiro autor.

Os argumentos contrários à autoria de Dionísio são convincentes e conclusivos. Por exemplo, o Corpus dionysiacum recebeu nítida influência da filosofia neoplatônica ${ }^{23}$, que floresceu nos primeiros séculos da era cristã. Trechos inteiros de Proclo, filósofo do século V depois de Cristo, se encontram em Da hierarquia celeste e em Dos nomes divinos. O desconhecimento das obras de Dionísio pelos Pais da Igreja dos primeiros cinco séculos - que nunca citaram esses textos - é impensável, em se tratando de livros que teriam sido produzidos ainda na época apostólica. Finalmente, o conteúdo do Corpus leva à conclusão de que ele é posterior ao Concílio de Calcedônia, de 451, e ao decreto conhecido como Henótico, de 482, que o imperador Zenão estabeleceu para eliminar controvérsias entre cristãos ortodoxos e monofisitas. "Conforme o decreto imperial, Dionísio evita mencionar expressamente as fórmulas de duas naturezas e duas vontades em Cristo, tal como havia definido o concílio; evita também as fórmulas atenuadas dos monofisitas, à maneira de Severo de Antioquia", nota T. H. Martin ${ }^{24}$. Mais: em Da hierarquia eclesiástica, Dionísio menciona o símbolo da fé católica, o Credo, que, como se sabe, foi elaborado nos séculos IV e V e

\footnotetext{
${ }^{22}$ Teodoro H. Martin, obra citada, página 52.

${ }^{23}$ A expressão "filosofia neoplatônica" - ou neoplatonismo - foi usada pela primeira vez por Thomas Taylor (1758-1835) para designar a filosofia mística e religiosa que surgiu em Alexandria, no Egito, no século III depois de Cristo. Embora inspirada em Platão, é bastante distinta do pensamento original do fundador da Academia. Amônio Saccas é considerado um dos fundadores do neoplatonismo. Outros filósofos neoplatônicos são Plotino, Porfírio, Jâmblico Hipácia, Proclo e Damáscio.

${ }^{24}$ Teodoro H. Martin, obra citada, página 56.
} 
introduzido na missa em 476. "Portanto, o livro não pode ter sido escrito antes dessa data."25

Delimitada a data de composição dos livros - entre o final do século V e o início do século $\mathrm{VI}^{26}$-, convencionou-se chamar seu ainda desconhecido autor por Pseudo Dionísio Areopagita, numa referência à agora frustrada tentativa de se fazer passar pelo cristão ateniense do século I.

Hipóteses sobre a verdadeira identidade do autor de Dos nomes divinos não faltam, desde as menos prováveis até algumas plausíveis. Atenágoras, em 1932, atribuiu o Corpus dionysiacum a Dionísio Magno (247-265), bispo de Alexandria; C. Pera calculou que o verdadeiro autor seria Basílio de Cesareia (329-379), um dos Pais da Igreja, e E. Elorduy apontou ninguém menos que Amônio Saccas (século II), o líder cristão da escola neoplatônica de Alexandria, mestre de Plotino e de Orígenes, de quem pouco se sabe e que não deixou nada escrito. Já no século XX, J. Stiglmayr opinou que o desconhecido teólogo seria, na realidade, Severo de Antioquia (465-538) ${ }^{27}$. Hans Urs von Balthasar e I. Hausherr sugeriram que se trata de Sergio de Reshaina (morto em 536), autor de uma tradução do Corpus para o sírio.

Apesar de todo esse esforço dos estudiosos, pouco se avançou na questão da identificação do autor do Corpus Dionysiacum. Pode-se pensar apenas, com certa segurança, que ele foi um monge - devido ao vasto conhecimento bíblico que demonstra - originário da Síria, a região de onde se difundiu sua obra, e que viveu no final do século V e início do século VI. T. H. Martin oferece uma boa síntese dos estudos atuais na área:

Em conclusão, as obras do Pseudo Dionísio Areopagita não podem ser de data anterior aos últimos decênios do século $\mathrm{V}$, pela inegável influência de Proclo, o silêncio da Igreja até esse tempo, o canto do Credo na missa, a cristologia conforme o concílio de Calcedônia e o Edito da União. Por outro lado, não tem sido possível identificar o autor do Corpus dionysiacum. Depois de tudo, destacam-se duas coisas, diríamos com Urs von Balthasar:

\footnotetext{
${ }^{25}$ Idem, idem, idem.

${ }^{26} \mathrm{O}$ léxico, a morfosintaxe e os intertextos presentes no Corpus dionysiacum permitem datar a obra por volta do ano 520, afirma Pablo A. Caballero em "Las ideas-clave de Los nombres Divinos de Pseudo Dionisio según el uso léxico" (Temas Medievales, v. 12, no. 1, 2004), citando Regina Suchla em Pseudo Dionysius Areopagita, De divinis nominibus, Berlim-Nova York, Walter de Gruyter, 1990).

27 Essa tese de Stiglmayr - exposta no artigo "Der sog. Dionysius und Severus von Antiochien", publicada em Scholastik III (1928), p. 1-27 e 161-189 - foi logo contestada por Robert Devresse em "Denys l'Areopagite et Sévère d'Antioche", publicado em Archives d'Histoire Doctrinale et Littéraire du Moyen Age, Paris, 1929, p. 159-167. Devresse critica Stiglmayr por se basear somente em biografias de Severo de Antioquia elaboradas por discípulos e amigos, como Zacarias de Gaza e Jean de Beith Aphtonia, que pintam um quadro bastante favorável do bispo de Antioquia. Outros dados biográficos de Severo, ignorados por Stiglmayr - aponta Devresse - dão conta que ele era iniciado nos mistérios pagãos, ordenou sacrifícios humanos e jamais renegou supertições pagãs. Em Beirute, foi supreendido na prática de feitiçarias e, para se livrar da condenação, simulou o batismo, que logo abjurou.
} 
primeira, que o desconhecido autor, 'sem ser pessoalmente monofisita, deve ser situado em um ambiente monofisita em razão de sua linguagem cristológica'; segunda, que é perder tempo seguir investigando por saber quem foi o autor do Corpus dionysiacum. ${ }^{28}$

O que se sabe com certeza são os pensadores que influenciaram o Pseudo Dionísio Areopagita. Um deles foi Plotino (205-270). Nascido em Licópolis, no Egito, estudou durante 11 anos na escola de Amônio Saccas, em Alexandria, onde teve contato com o neoplatonismo e o cristianismo. Participou de uma expedição à Pérsia - liderada pelo imperador Gordiano -, que lhe deu a oportunidade de conhecer a filosofia persa e indiana. Aos 40 anos, fixou-se em Roma e passou a se dedicar ao ensino. Suas ideias estão expostas nas Enéadas, conjunto de seis livros com nove capítulos cada, organizados por Porfírio, discípulo de Plotino.

Nas Enéadas se encontra nitidamente a fonte de uma parte substancial da teologia do Pseudo Dionísio Areopagita. Como explica T. H. Martin, a filosofia de Plotino é um método para a alma se elevar - através da catarse ou purificação - até a união com o um ${ }^{29}$, que é a plenitude de ser, a supraessência, o Ser sobre todo ser. O um é princípio do ser. Nada existe se não por meio do um. "O um em si é o manancial de toda unidade participada, de todo ser, de toda multiplicidade. Mas o um transcende tudo. Cada coisa não passa de ser determinada unidade, não é o um."30

Como é infinitamente transcendente a todas as coisas, o um não pode ser definido nem explicado. Ele não é nada do que existe, como diz Plotino:

\begin{abstract}
A unidade, pois, não é princípio-intelectual, mas alguma coisa mais elevada ainda: princípio-intelectual é ainda um ser, mas esse primeiro não é nenhum ser, mas precede todo ser. Ele não pode ser um ser, pois um ser tem o que nós podemos chamar a forma de sua realidade, mas a unidade é sem forma, mesmo forma intelectual. Geradora de tudo, a unidade não é nada do que existe. Nenhuma coisa nem quantidade nem qualidade nem intelecto nem alma. Não está em movimento nem em repouso, nem no espaço nem no tempo. Ele é o auto-definido, único em forma, ou melhor, sem forma, existindo antes da forma. ${ }^{31}$
\end{abstract}

Causa de todas as coisas, o um produz a multiplicidade do mundo através do Entendimento ( $\operatorname{co}(\omega)$, essa manifestação do um que pensa as essências e, assim, lhes dá o ser. "Ser e pensar fora do um se identificam. O Bem-Entendimento, mediador entre o

\footnotetext{
${ }^{28}$ Teodoro H. Martin, obra citada, páginas 58-59.

${ }^{29} \mathrm{O}$ um é a forma característica como os filósofos neoplatônicos se referem ao princípio de todas as coisas. Adotamos grafar esse termo em letra minúscula para livrar a palavra de um caráter pessoal, que contrariaria a ideia neoplatônica de um primeiro princípio impessoal, inominável e insondável.

${ }^{30}$ Idem, idem, páginas 8-9.

${ }^{31}$ Enéadas VI, 9, 3.
} 
um e o ser ou seres, é anterior ao ser. O mundo, pois, aparece como uma hierarquia, gradação de formas, mais ou menos perfeitas, à medida de seu distanciamento da unidade, da qual dependem todas as formas. $" 32$

As essências se unem à matéria através da Alma. "Assim como o um produz a Inteligência, a Inteligência produz a Alma, intermediária entre o mundo inteligível e o sensível, ordenadora dos elementos constitutivos do cosmos, causa de sua beleza. É a Alma do mundo", explica T. H. Martin ${ }^{33}$. As almas individuais são derivações da Alma do mundo:

\footnotetext{
"Cada alma vem a ser intermediária entre o mundo inteligível que ela contempla e o mundo sensível em que se projeta, com o que está encadeada. O homem, por seu corpo, está comprometido com o mundo sensível, enquanto por sua alma está empenhado no processo de retorno, de volta ou conversão à Alma do mundo, à contemplação do inteligível." ${ }^{34}$
}

O caminho de retorno das essências ao um possui três etapas, segundo Plotino: purificação, iluminação e união. Purificação consiste na catarse ou liberação das paixões, no domínio da alma e na moderação. Iluminação é a contemplação das ideias, formas ou essências a imitar, que impulsiona o homem para o seu fim último, a visão do um. Finalmente, a união é a identificação, no máximo grau possível, com o um.

Comentando a influência de Plotino sobre a teologia do Pseudo Dionísio Areopagita, T. H. Martin afirma:

O Corpus dionysiacum está igualmente orientado pela tríade plotiniana do um $(\mu \mathrm{ov} \rightarrow)$, princípio e fim ou término do círculo criador; o BemInteligência, caminho $(\pi \rho \circ\rangle \delta o \omega)$ criador por onde todo ser vem a existir fora do um. Cadeia ao mesmo tempo descendente e ascendente, que são as hierarquias: celeste ou mundo angélico e eclesiástica, pela qual todo o terreno se diviniza e volta ao um, ponto de partida e término da viagem (...). As três etapas ou vias de ascensão - purificação, iluminação, união -, que ocorrem com frequência nos escritos do Areopagita, este os toma de Plotino e transmite a toda a cristandade. ${ }^{35}$

Como Plotino, Jâmblico (250-325) foi um filósofo neoplatônico que imprimiu profundas marcas no pensamento do Pseudo Dionísio Areopagita. Natural de Cálcis, na Síria, tornou-se discípulo de Porfírio em Roma. Depois, separando-se do mestre, fundou a escola neoplatônica da Síria. Escreveu tratados sobre Pitágoras e comentários sobre os livros de Aristóteles e de Platão, de que só restam fragmentos. Em contraste com Plotino, que buscava a união mística com o divino através do entendimento, Jâmblico

\footnotetext{
${ }^{32}$ Teodoro H. Martin, obra citada, página 9.

${ }^{33}$ Idem, idem, página 9.

${ }^{34}$ Idem, idem, pagina 10.

${ }^{35}$ Idem, idem, página 11.
} 
deu ênfase à teurgia ${ }^{36}$ - a prática de rituais para invocar e se relacionar com os deuses -, da qual faz uma incisiva defesa no seu livro Dos mistérios.

Além de Plotino e Jâmblico, outro filósofo neoplatônico que exerceu forte influência sobre o Pseudo Dionísio Areopagita foi Proclo (412-485). Nascido em Bizâncio, estudou direito, retórica, matemática e filosofia em Alexandria. Em 430, ingressou na Academia de Atenas para estudar filosofia. Tornou-se o dirigente da escola, ficando nessa função por cerca de 40 anos, até sua morte. Foi um adversário dos cristãos. Favoreceu práticas religiosas pagãs para combater o crescimento do cristianismo entre a população. Com esse objetivo escreveu os Comentários aos oráculos caldeus e vários hinos.

Uma das obras de Proclo é o Hino a Hécate e a Ianus, que diz:

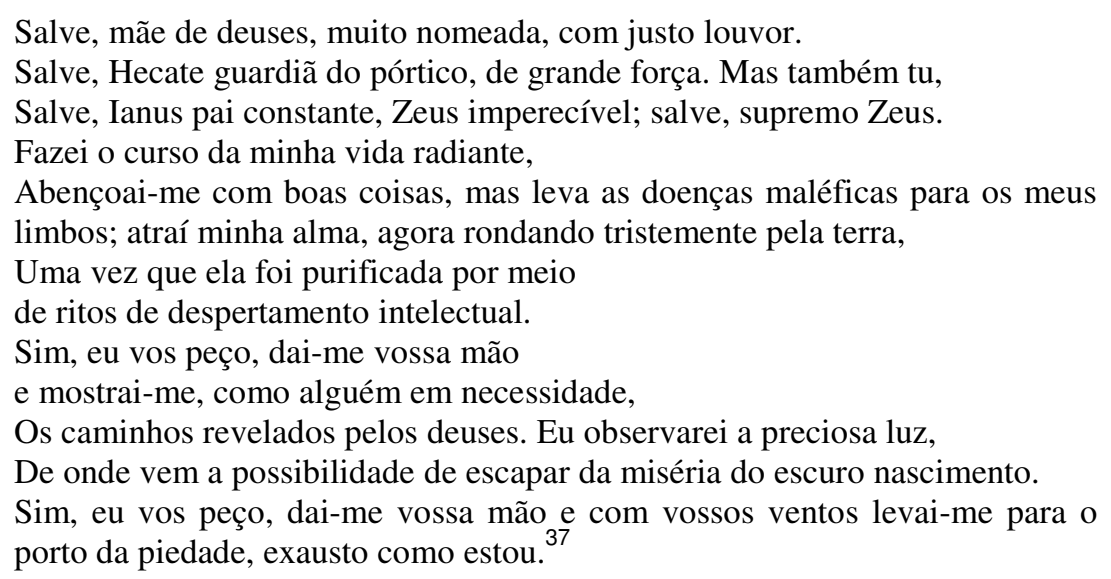

Proclo compôs ainda a Teologia platônica, os Elementos de teologia e obras sobre os principais livros de Platão, como os Comentários à República, ao Timeu e ao Parmênides. O Liber de causis ("Livro das causas"), texto que foi muito lido na Idade Média e era considerado obra de Aristóteles, na realidade se trata de um resumo dos Elementos de teologia de Proclo, provavelmente feito por um intérprete árabe.

A transcendência inatingível do um, a pluralidade que participa do princípio primeiro, os graus de perfeição das coisas - esses conceitos tão presentes na obra do

\footnotetext{
${ }^{36}$ Do grego $\left.\psi \varepsilon\right\rangle \varphi($ deus ) e $f \rho \gamma o v$ (trabalho).

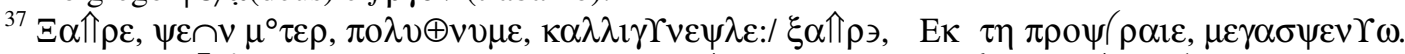

$\lambda \lambda \quad \kappa \alpha \Leftarrow \alpha\left[\tau \int \omega / \xi \alpha \Uparrow \rho \ni, \quad\right.$ I $\alpha v \varepsilon \pi \rho \circ \pi \quad \tau o \rho, Z \varepsilon(\phi \psi \tau \tau \varepsilon: \xi \alpha \Uparrow \rho \ni,|\pi \alpha \tau \varepsilon Z \varepsilon| . / \tau \varepsilon(\xi \varepsilon \tau \varepsilon$

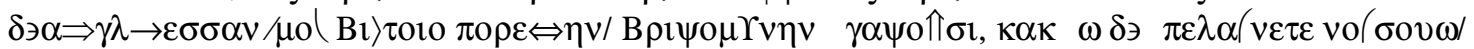

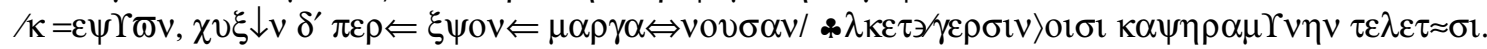
l

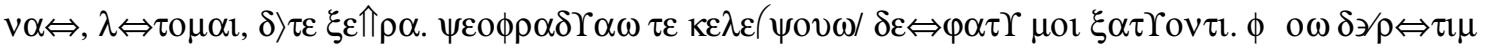
ov

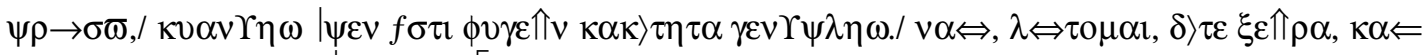

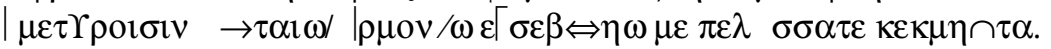


Pseudo Dionísio Areopagita se encontram em Proclo. Entre os 211 aforismos que formam os Elementos de teologia, por exemplo, estão estes:

Toda pluralidade participa do um de algum modo. ${ }^{38}$

Toda pluralidade é subordinada ao um. ${ }^{39}$

Todo ser que produz um outro é de ordem superior a seu produto. ${ }^{40}$

De todos os seres o princípio e a causa primeira é o bem. ${ }^{41}$

De todos os seres que se multiplicam procedendo deles, os primeiros são mais perfeitos que os segundos, os segundos mais perfeitos que os graus posteriores, e assim por diante. ${ }^{42}$

Toda causa propriamente dita é transcendente ao seu efeito. ${ }^{43}$

Toda alma particular tem o poder de descer na geração e de remontar indefinidamente da geração ao ser. ${ }^{44}$

Embora menos conhecidos e citados, Porfírio (232-304) e Damáscio (462-538) também deram importantes contribuições para a teologia do autor do Corpus. Segundo Salvatore Lilla ${ }^{45}$, o estudo dessas contribuições é fundamental para a compreensão de aspectos importantes do pensamento teológico e da doutrina mística do Pseudo Dionísio Areopagita.

Um desses aspectos é a interpretação do diálogo platônico Parmênides. Como mostrou E. Corsini ${ }^{46}$, diz Lilla, a interpretação de Dionísio segue aquela de Proclo, segundo a qual as conclusões negativas da primeira hipótese do diálogo se referem à mônada $(\mu \mathrm{ov} \rightarrow)$ do primeiro princípio, enquanto as conclusões positivas da segunda hipótese têm por objeto sua processão $(\pi \rho \circ\rangle \delta \omega \omega)$. Porém, em algumas passagens de Dos nomes divinos e de Da teologia mística, Dionísio aplica simultaneamente a Deus tanto os conceitos negativos da primeira hipótese como os conceitos positivos da segunda. Isso não se encontra em Proclo nem é uma contribuição original de Dionísio, defende Lilla, mas se acha num fragmento anônimo de um comentário ao Parmênides que a crítica atribui a Porfírio. "Seu autor (do fragmento), atribuindo simultaneamente

\footnotetext{
${ }^{38}$ Proclo, Elementos de teologia, 1.

${ }^{39}$ Idem, idem, 5.

${ }^{40}$ Idem, idem, 7.

${ }^{41}$ Idem, idem, 12.

${ }^{42}$ Idem, idem, 36.

${ }^{43}$ Idem, idem, 75.

${ }^{44}$ Idem, idem, 206.

${ }^{45}$ Em "Pseudo-Denys l'Aréopagite, Porphyre et Damascius" (Andia, Ysabel de. Denys l'Aréopagite e sa posterité en Orient et en Occident, Paris, Institut d'Études Augustiniennes, 1997, p. 117-152).

${ }^{46}$ Em Il trattato De divinis nominibus dello pseudo-Dionigi e i commenti neoplatonici al Parmenide (Torino, 1962).
} 
os conceitos positivos e negativos das duas primeiras hipóteses do Parmênides ao mesmo 'um', considerado em sua moné e em sua proódos, adota uma interpretação desse diálogo que é exatamente a que se encontra nas passagens dionisianas", acrescenta Lilla.

A concepção de Deus em Dionísio e em Porfírio também é semelhante, sugere o autor. Enquanto para Plotino e Proclo o primeiro princípio é o um negativo absolutamente simples, que exclui toda ideia de pluralidade e distinção, para Porfírio o um é simples considerado "nele mesmo", ou seja, segundo sua forma primeira, mas, ao mesmo tempo, ele não é nem um nem simples, se for considerado segundo seus três modos de ser: existência, vida e intelecto. "A correspondência entre Dionísio e Porfírio não poderia ser, portanto, mais estreita: a doutrina dionisiana de Deus, ao mesmo tempo henádico e triádico, não-um enquanto acima do um e não-ser enquanto acima do ser, já está praticamente formada no comentário porfiriano sobre o Parmênides (e nos oráculos caldeus)", afirma Lilla. "Apesar das fortes analogias com o um procliano, sobretudo no que concerne a suas conotações negativas e suas relações com os seres, o um dionisiano, considerado na sua estrutura interna e em certas propriedades negativas, lembra mais aquele do autor do comentário." Porfírio foi discípulo de Plotino. Compôs uma biografia do seu mestre e comentários aos livros de Platão e de Aristóteles, com destaque para o Isagoge, um comentário às Categorias, de Aristóteles, que teve muita influência na lógica medieval.

Quanto a Damáscio, Lilla vê paralelos entre a obra desse filósofo - autor de Problemas e soluções sobre o primeiro princípio, entre outros livros - e o pensamento do Pseudo Dionísio Areopagita no que se refere, por exemplo, à concepção do um que contém o todo: "É justamente a ideia da presença de todos os seres na moné do um que permite estabelecer um paralelo muito estreito com Damáscio, embora ela não esteja de todo ausente em Plotino, Jâmblico e Proclo. O um contém tudo na absoluta simplicidade de sua moné, onde tudo se reduz à sua unidade", escreve Lilla. Essa ideia está presente no neoplatonismo anterior, mas é em Damáscio que ela é particularmente desenvolvida, até se tornar uma das características principais da doutrina neoplatônica do um, acrescenta o autor, citando vários trechos semelhantes de Dos nomes divinos e do Primeiro princípio damasciano. Nascido na Síria, Damáscio (462-538) foi sucessor de Proclo como diretor da Academia de Atenas, cargo que ocupava quando esta foi fechada, em 529, a mando do imperador Justiniano, sob a acusação de paganismo. 
Porém, não são apenas esses filósofos pagãos - Plotino, Jâmblico, Proclo, Porfírio e Damáscio - que estão na base do pensamento do Pseudo Dionísio Areopagita. Este tem elementos também do teólogo cristão Gregório de Nissa (335-394), um dos Pais da Igreja. Com seu irmão Basílio de Cesareia (329-379) e Gregório Nazianzeno (329-390), Gregório forma o trio conhecido como Padres Capadócios, famosos no século IV por defender a ortodoxia da fé contra as heresias - principalmente no que se refere à doutrina da Trindade.

Pensador neoplatônico, Gregório de Nissa cristianiza os conceitos empregados por Plotino. No livro Vida de Moisés, ele divide o caminho de ascensão a Deus em três etapas: a sarça ardente, a nuvem e as trevas. A primeira se refere à purificação, em que ocorre o domínio das paixões e a paz consigo mesmo. A segunda consiste em levantar o pensamento a Deus, abandonando a tendência dos sentidos de se voltar para baixo. A terceira é a experiência mística, o sentimento da imagem de Deus na alma, uma visão muito superior à contemplação intelectual das etapas anteriores.

É dessa forma que Gregório de Nissa interpreta a subida de Moisés ao Monte Sinai, conforme descrito no Exodo, um dos livros do Velho Testamento. Segundo ele, quando a mente humana avança diligentemente em direção a Deus e atinge a contemplação, deixando para trás tudo o que é observado - não apenas o que os sentidos compreendem, mas o que a inteligência pensa ver -, ela ganha acesso ao invisível e incompreensível, e ali vê Deus. "Esse é o verdadeiro conhecimento do que é pensado. Isso é o ver que consiste em não ver, porque o que é pensado transcende todo conhecimento, estando separado de todos os lados pela incompreensibilidade, como por um tipo de trevas", afirma Gregório. "Quando, portanto, Moisés cresceu em conhecimento, ele declarou que havia visto Deus nas trevas, ou seja, que ele veio a saber que o divino está além de todo conhecimento e compreensão." 47

Como afirma T. H. Martin:

Dionísio encontrou em São Gregório, antes de tudo, um mestre na aplicação da linguagem plotiniana à realidade sobrenatural da graça em plenitude santificante (...). Ao que parece, dentro da Igreja ninguém melhor do que são Gregório de Nissa preparou o caminho para a chegada do Areopagita, assim como foram Proclo e Plotino no campo não-cristão. ${ }^{48}$

Essa variada influência, somada às Escrituras cristãs - o Velho e o Novo Testamento -, que permeiam o pensamento do Pseudo Dionísio Areopagita, produziu

\footnotetext{
${ }^{47}$ Gregory of Nissa, The life of Moses, translation by Abraham J. Malherbe and Everett Ferguson, Paulist Press, New York, 1978, p. 95.

${ }^{48}$ T. H. Martim, obra citada, página 15.
} 
um resultado notável. O Corpus dionysiacum é, enfim, uma tentativa de explicar, da forma mais universal possível e do ponto de vista do cristianismo, a existência e o mundo ${ }^{49}$. Em sua obra, o autor relaciona o homem, os seres vivos e a matéria inanimada com o Criador, apontando a origem de todas as coisas, seus mais profundos anseios, sua condição e sua finalidade última.

Isso se revela já no tratado que abre o Corpus, chamado Da hierarquia celeste. Nele, o autor especula como Deus, que é inacessível e absolutamente transcendente, faz chegar sua luz aos homens, graças à qual estes podem conhecer aquele que está além de todo conhecimento possível. Essa transmissão se dá através das hierarquias celestes, formadas pelos seres que se cercam de Deus - o um, a Tearquia, Deidade ou Causa Universal, como também o Pseudo Dionísio Areopagita se refere ao divino. Hierarquia, diz o autor, é uma ordem, um conhecimento e um poder sagrados ${ }^{50}$, que conduzem à purificação, iluminação e perfeição dos seres que estão submetidos a ela.

Existem três hierarquias divinas. Elas têm a missão de, recebendo a iluminação dos seres que lhes são superiores, transmitir a mesma luz aos inferiores. Em outras palavras, elas são responsáveis pela purificação, iluminação e perfeição dos que lhes são subordinados. Nesse processo, há gradações. A primeira hierarquia está mais próxima de Deus ${ }^{51}$, recebe diretamente dele a iluminação, que por isso é mais intensa. Essa luz diminui de intensidade à medida que é transmitida às hierarquias inferiores, até chegar à hierarquia dos homens. Nesse último estágio, os raios divinos já estão adaptados às condições dos seres humanos, para que estes possam contemplá-los.

\footnotetext{
${ }^{49}$ Há intérpretes que consideram o Pseudo Dionísio Areopagita um teólogo monofisita, portanto, um herege, segundo a posição oficial da Igreja Católica desde o Concílio de Calcedônia, em 451. De fato, o Corpus dionysiacum foi muito lido e comentado desde o século VI por teólogos monofisitas e nestorianos - estes também considerados hereges pelo Concílio de Éfeso, em 431, por defender que em Jesus Cristo há duas naturezas separadas, a humana e a divina. Entre esses teólogos estão os nestorianos José Hazzaya (século VII), Babai Magno (morto em 628) e Timóteo I, patriarca de Constantinopla (século IX), e os monofisitas Teodósio I, patriarca de Alexandria (século VI), Jacob de Edessa (640-708) e Stephan Bar Soudaili. Sendo assim, o pensamento do Pseudo Dionísio Areopagita poderia talvez não ser considerado uma explicação filosófica legitimamente cristã do mundo. Porém, outros intérpretes, inclusive o autor deste trabalho, consideram o Corpus uma obra ortodoxa, que defende - usando termos neoplatônicos e pagãos, o que pode justamente ter gerado desconfianças quanto à sua ortodoxia - os principais dogmas do cristianismo, como as inseparáveis naturezas divina e humana de Cristo, a Trindade, o nascimento virginal e, contra o emanatismo e o panteísmo, a Criação ex nihilo. Essa interpretação encontra adeptos desde os séculos VI e VII, com teólogos como João de Citópolis e Máximo o Confessor. Dessa forma, de acordo com esse ponto de vista, a teologia e a filosofia do Pseudo Dionísio Areopagita são uma autêntica expressão do pensamento cristão.

${ }^{50} \tau \quad \varphi \imath \omega \Rightarrow \varepsilon \rho \quad \kappa \alpha \Leftarrow / \pi \imath \sigma \rightarrow \mu \eta \eta \kappa \alpha \Leftarrow N \Upsilon \rho \gamma \varepsilon \imath \alpha($ Da hierarquia celeste III, 1$)$.

51 Não se trata de proximidade física, como afirma o Pseudo Dionísio Areopagita: "Entendo por proximidade a capacidade maior possível de receber Deus" (Carta VIII, 2).
} 
Cada uma das três hierarquias celestes possui três ordens diferentes. A primeira das hierarquias é formada pelos serafins, os querubins e os tronos, nomes que correspondem $^{52}$ a funções ou realidades distintas ${ }^{53}$. Os serafins são assim chamados, diz o Pseudo Dionísio Areopagita, porque a palavra significa "incandescente", o que representa o movimento incessante em torno das realidades divinas e seu poder de gravar nos subordinados chama semelhante. Representa também o poder de purificar por meio do fogo e de afugentar as trevas. O nome querubim quer dizer plenitude de conhecimento, transbordante de sabedoria. Significa o poder de conhecer e de ver Deus, de receber os dons de sua luz e de compartilhá-los com os inferiores. Trono se refere à capacidade de estar muito acima das deficiências terrenas, de se ver livre de qualquer paixão e cuidados materiais e de viver para sempre na presença do Altíssimo.

Por estar mais próximos de Deus, os serafins, querubins e tronos são as criaturas mais perfeitas, mais santas e mais semelhantes ao Criador entre todas as que existem:

\begin{abstract}
"A primeira hierarquia das inteligências celestes está hierarquicamente dirigida pela fonte de toda perfeição, porque pode se elevar diretamente até ela. Recebe, segundo sua capacidade, plena purificação, luz infinita, perfeição completa. Purifica-se, ilumina-se, torna-se perfeita até ficar imune de qualquer debilidade, saturada de plena luz. E alcança a perfeição como participante do conhecimento e sabedoria primordial. ${ }^{, 54}$
\end{abstract}

Cabe a essa primeira hierarquia transmitir a luz divina aos seres chamados dominações, virtudes e potestades, que formam a segunda hierarquia celeste. As dominações dizem respeito a um elevar-se livre de tendências terrenas, acima de qualquer servidão, num esforço constante para alcançar a Deus. Virtude alude à força inquebrantável, à firmeza que exclui toda fraqueza e faz levantar-se até o divino, verdadeira imagem da Potência divina, fonte de toda fortaleza, da qual toma forma. As potestades indicam a disposição de receber os dons divinos e revelam a natureza ordenada do poder celestial e intelectual. "Desse modo, a hierarquia das inteligências celestes mostra sua configuração com Deus. Como ficou dito, assim obtém a

\footnotetext{
${ }^{52}$ Como se sabe, o Oriente dá extrema importância para a relação entre o nome e função das coisas, o que não ocorre no Ocidente.

53 "Cada denominação dos seres tão superiores a nós apresenta maneiras distintas de imitar a Deus e de configurar-se com Ele" (Da hierarquia celeste VIII, 1): $\quad \kappa \alpha \Leftarrow \gamma \rho / \kappa \sigma \tau \eta \tau \cap v \mid \pi^{\prime} \rho " \mu \quad \omega \circ\lceil\sigma \mathrm{l} \cap \nu$

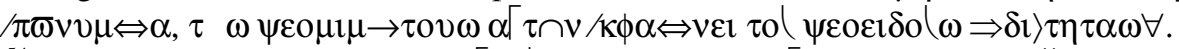

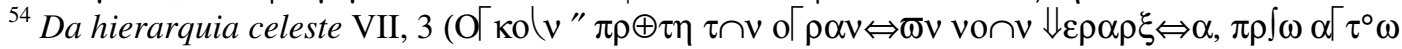

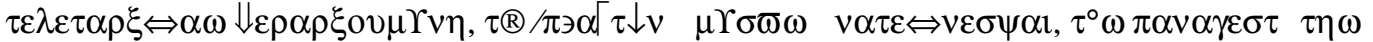

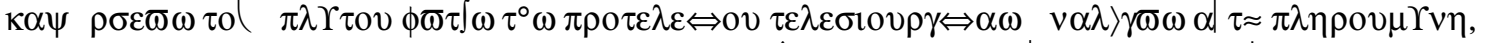

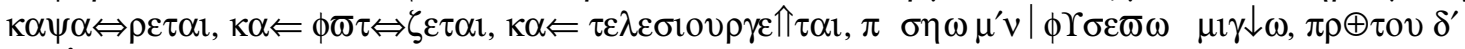

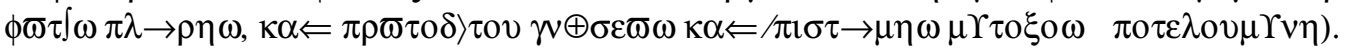


purificação, a iluminação e a perfeição, recebendo de Deus as iluminações que chegam através da primeira ordem hierárquica." 55

Finalmente, a terceira hierarquia é composta pelos principados, arcanjos e anjos. O nome principados faz referência ao mando principesco exercido por esses seres, que têm a capacidade de se voltar para o princípio de todas as coisas e guiar outros até ele. Os arcanjos, intermediários entre os principados e os anjos, se comunicam com aqueles seres superiores, orientando-se para o princípio fundamental e recebendo sua marca, e transmitem aos seres inferiores, os anjos, essa mesma marca. A ordem dos anjos é a mais próxima da terra. São eles que transmitem aos homens o conhecimento de Deus. "É ela que faz as revelações e, segundo seus distintos graus, preside as hierarquias humanas, a fim de que a elevação e retorno a Deus, comunhão e união com ele suceda como é devido." $" 56$

Da hierarquia celeste explica que as hierarquias foram estabelecidas por Deus para que o homem pudesse ter acesso, pelo menos parcialmente, ao conhecimento das inacessíveis regiões celestiais, que de outra forma ficariam totalmente separadas da humanidade. $\mathrm{O}$ raio divino, de tão intenso, não poderia iluminar os seres humanos se não fosse transmitido através de figuras sagradas, mais adaptadas ao seu modo natural de conhecer. "As hierarquias imateriais se revestiram de múltiplas figuras e formas materiais, a fim de que, conforme nossa maneira de ser, nos elevemos analogicamente desde esses signos sagrados à compreensão das realidades espirituais, simples, inefáveis." "57

Assim como as hierarquias celestes purificam, iluminam e aperfeiçoam os seres que lhe estão sujeitos, também as hierarquias humanas atuam com o objetivo de elevar os homens a Deus. É o que afirma o segundo livro do Corpus dionysiacum, denominado Da hierarquia eclesiástica. Nessa obra, o Pseudo Dionísio Areopagita se refere à Igreja cristã. Através de seus líderes e suas cerimônias, a instituição transmite a luz divina purifica, ilumina e aperfeiçoa - àqueles que fazem parte dela. "Nossa hierarquia é

\footnotetext{
$\begin{array}{llll}55 & \text { Da } & \text { heleste } & \text { VIII, }\end{array}$

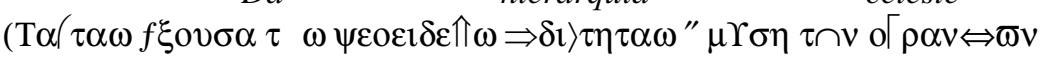

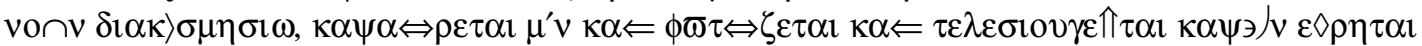

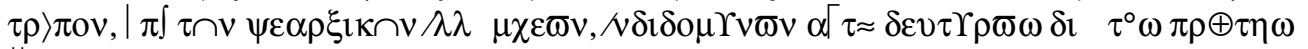

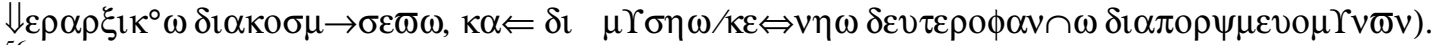

${ }^{56}$ Da hierarquia celeste IX, 2.

${ }^{57}$ Da hierarquia celeste I, 3.
} 
símbolo e adaptação à nossa maneira de ser. Necessita servir-se de signos sensíveis para nos elevar espiritualmente às realidades do mundo inteligível. ${ }^{, 58}$

Um desses signos sensíveis é o rito da iluminação, o momento do nascimento de Deus no cristão, como o Pseudo Dionísio Areopagita se refere ao batismo. A cerimônia, cheia de simbolismos, tem início com um hino entoado por todos os presentes - o bispo, os sacerdotes, os presbíteros, os diáconos, o candidato ao batismo e seu padrinho, aquele que o apresentou ao bispo. Após as primeiras orações, o bispo ordena aos diáconos tirar as roupas do batizando. Este, de pé, volta-se para o Ocidente, estende as mãos em atitude de abjuração e por três vezes renega o diabo. Em seguida, volta-se para o Oriente e, com os olhos e as mãos para o céu, promete seguir Cristo e a doutrina revelada por Deus. O batizando é ungido com óleo pelos sacerdotes e entregue novamente ao bispo, que o submerge na água por três vezes. A cada imersão, os sacerdotes repetem o nome do iniciado e o bispo invoca as três Pessoas da Trindade. Finalmente, o batizando recebe roupas brancas e é mais uma vez ungido com óleo pelo bispo, que lhe faz o sinal da cruz.

Esses ritos encerram simbolicamente profundos significados e revelam realidades espirituais que, sem eles, permaneceriam desconhecidos ao homem, segundo o Pseudo Dionísio Areopagita. Voltar-se para o Ocidente e abjurar sugere que é impossível àquele que participa do um viver ao mesmo tempo nas trevas do mal. É preciso expulsar o que é dessemelhante a Deus e renunciar completamente a tudo que se oponha à configuração com Ele. Mas não basta deixar o mal. É preciso, com todas as forças, buscar a verdade, elevar-se à mais alta perfeição da Deidade. Eis o significado das mãos e olhos voltados para o alto, com o batizando voltado para o Oriente.

A imersão simboliza a morte, que é o desaparecimento do corpo e a permanência da alma. Ao submergir três vezes, o batizando imita Cristo, que passou três dias e três noites no sepulcro. As roupas brancas lembram a luz que agora brilha na nova vida. $\mathrm{O}$ suave odor do óleo representa a união com o Espírito Santo. "Os símbolos sagrados são realmente expressão sensível de realidades inteligíveis. Mostram o caminho que leva aos inteligíveis, que são o princípio e a ciência de quanto a hierarquia representa sensivelmente" ${ }^{, 59}$, repete o Pseudo Dionísio Areopagita.

Outro símbolo revelador do invisível é o sacramento da eucaristia, que também começa com um canto sagrado e leituras bíblicas. Os catecúmenos se retiram e ficam

\footnotetext{
${ }^{58}$ Da hierarquia eclesiástica I, 5.

${ }^{59}$ Da hierarquia eclesiástica II, 2.
} 
somente os dignos de comungar, os já iniciados. Diáconos e sacerdotes colocam sobre o altar o pão e o cálice com vinho. O bispo e os sacerdotes lavam as mãos. O bispo faz uma prédica louvando as obras de Deus. Ele comunga primeiro e convida os demais a também fazê-lo. Ao final, conclui a cerimônia com uma ação de graças.

Tudo isso são simbolismos que remetem a profundas realidades espirituais, segundo o Pseudo Dionísio Areopagita. O lavar as mãos, diz o autor, representa a pureza diante de Deus. Significa também que Cristo conhece todos os pensamentos dos homens, inclusive os mais secretos, e que Ele mesmo estabeleceu esse ritual de purificação. A distribuição do pão e do vinho revela como, por amor ao homem, Cristo deixou o mistério de sua divindade e tomou forma humana, encarnando e vivendo na terra, sem pecado. Mostra ainda que Ele desceu dos céus sem deixar de ser o que era, o Deus Todo-Poderoso. E manifesta que toda a humanidade está convidada à comunhão com Ele.

Para o Pseudo Dionísio Areopagita, a celebração da eucaristia é "o sacramento dos sacramentos" $" 60$ :

\footnotetext{
"A perfeição de outros símbolos hierárquicos se consegue somente por meio dos divinos e perfeccionantes dons da comunhão. Pois é quase impossível celebrar algum dos sacramentos hierárquicos sem que a sagrada eucaristia, ponto culminante de todo rito, consiga, por sua divina operação, a união com o um em quem receba o sacramento."
}

Da hierarquia eclesiástica mostra ainda outros símbolos usados pela Igreja para ensinar as realidades espirituais aos homens. Fala da unção com óleo, das cerimônias de ordenação dos sacerdotes, dos ritos de consagração dos monges e dos funerais. Todas elas são capazes de elevar os homens à contemplação do um. Como ocorre nos céus, também na terra a luz divina é transmitida na medida da capacidade do ser que a recebe. Assim, cabe ao bispo aperfeiçoar os sacerdotes, que iluminam os diáconos, que purificam os iniciados ${ }^{62}$.

Depois da teologia simbólica predominante em Da hierarquia eclesiástica, chega-se à teologia conceitual de Dos nomes divinos, o terceiro livro do Corpus dionysiacum. Com ele, o Pseudo Dionísio Areopagita tem o objetivo de revelar Deus através dos nomes com que é chamado no Velho e no Novo Testamento. Entre os vários nomes analisados pelo autor, destacam-se quatro: Bem, Ser, Vida e Sabedoria.

\footnotetext{
${ }^{60}$ Da hierarquia eclesiástica III, 1.

${ }^{61}$ Da hierarquia eclesiástica III, 1.

${ }^{62}$ Da hierarquia eclesiástica $\mathrm{V}, 8$.
} 
Deus é chamado Bem porque, em sua bondade, ilumina todas as coisas, cria, dá a vida, mantém, renova e aperfeiçoa todos os seres, assim como ocorre com o sol, que com sua luz beneficia aqueles que ilumina. Deus possui em si a essência de todas as coisas, antes que elas venham a ser. É causa de tudo e princípio de unidade. Como tal, atrai todas as coisas para si. A Criação inteira, instintivamente, aspira a Ele, pois é a Causa perfeita e o fim último de tudo: os seres espirituais e racionais o desejam pelo conhecimento, os dotados de sensibilidade, pela sensação e os que vegetam, pelo seu apetite vital inato. Até os objetos inanimados tendem à união com o Bem ${ }^{63}$.

Deus é Bem também porque Ele é o Belo ${ }^{64}$, a Formosura, ensina o Pseudo Dionísio Areopagita. Como a luz se irradia sobre todas as coisas, assim a Formosura reveste os seres com a formosura. Esta, antes que existisse, já se encontrava em Deus, sua fonte. "Nada há formoso que não tenha brotado daquela simplíssima Formosura. Dessa Formosura procedem todas as coisas, belas cada qual à sua maneira."65 Esse Bem, essa Formosura é causa da multiplicidade de bens e formosuras presentes no mundo sensível. "Por isso, todos os seres, cada qual à sua maneira, estão abertos uns aos outros, se comunicam entre si e se compenetram sem perder sua identidade."66

Mas não é só. Deus é denominado Bem porque Ele é o Amor. Toda a Criação é consequência do amor de Deus, explosão, transbordamento da bondade de Deus, que não ficou encerrada em si mesma, mas induziu o Criador a usar a abundância de seu poder para criar o mundo e conceder a vida ${ }^{67}$. Citando palavras de Hieroteo ${ }^{68}$, seu suposto mestre, o Pseudo Dionísio Areopagita destaca que Deus é a causa do amor e de todo desejo amoroso. "É o fim último por que todas as coisas em todo lugar se esforçam em alcançar." 69

Ao falar do Bem, o Pseudo Dionísio Areopagita se vê levado a discorrer sobre seu oposto, o mal ${ }^{70}$. Para ele, o mal não tem essência nem existência própria. Acontece

\footnotetext{
${ }^{63}$ Dos nomes divinos IV, 4.

${ }^{64} \mathrm{Em}$ grego, bem, belo e bom se confundem na mesma palavra $\left.\kappa \alpha \lambda \lambda\right\rangle \omega$ (kallós).

${ }^{65}$ Dos nomes divinos IV, 7.

${ }^{66}$ Dos nomes divinos IV, 7.

${ }^{67}$ Dos nomes divinos IV, 10.

${ }^{68}$ Hieroteo é provavelmente um personagem fictício ou pseudônimo de alguém que teria sido mestre do Pseudo Dionísio Areopagita, que o cita nas suas obras como um dos seus mentores, ao lado do apóstolo Paulo.

${ }^{69}$ Dos nomes divinos IV, 16.

${ }^{70}$ A concepção do mal no Pseudo Dionísio Areopagita está fundada no neoplatonismo de Proclo. Vários trechos do capítulo IV de Dos nomes divinos que abordam o tema são transcrições literárias do tratado conhecido como De malorum subsistentia ("Da existência do mal"), de Proclo. Isso foi notado pela primeira vez por J. Stiglmayr, em "Der Neuplatoniker Proclus als Vorlage des Sogen - Dionysius Areopagita in der Lehre vom Uebel” (Historisches Jahrbuch XVI, 1895, p. 253-273; 721-748). Carlos
} 
que todas as coisas do mundo sensível, sendo criaturas feitas pelo Bem, não podem ser más, pois o Bem só gera o bem e não o mal. É impossível que a Fonte do bem produza o mal. Em outras palavras, se algo existe, é bom, porque provém da Causa de todas as coisas, que é sumamente boa. Mas a bondade de Deus pode estar mais ou menos presente nas coisas. Ela se estende sobre tudo, porém está totalmente presente em alguns seres, em outros, menos e em outros ainda, minimamente. "Todas as coisas, pelo mero fato de ser, são boas e procedem do Bem. São deficientes em ser e bondade segundo estejam mais ou menos distantes do Bem."71

Se algo está completamente distante do Bem, esse algo não existe, pois sem o Bem não há essência nem vida nem movimento. Até mesmo os demônios, diz o Pseudo Dionísio Areopagita, têm algo de bem, uma vez que existem. Se não tivessem pelo

Steel voltou ao assunto em "Proclus et Denys: de l'existence du mal" (Andia, Ysabel de. Denys l'Aréopagite e sa posterité en Orient et en Occident, Paris, Institut d'Études Augustiniennes, 1997, p. 86116). Steel afirma: "Dionísio discute as mesmas questões que Proclo e na mesma ordem, segue sua exposição passo a passo, retoma seus argumentos, objeções e soluções, explora seus exemplos e utiliza seu vocabulário técnico. E, sobretudo, defende sem nenhuma reserva a mesma doutrina do mal que Proclo. Frequentemente Dionísio se limita a copiar textualmente passagens do seu modelo; outras vezes, faz uma paráfrase. Há trechos em que se pode corrigir o texto corrompido de Proclo pela passagem paralela em Dionísio, e vice-versa. Pode-se constatar igualmente como Dionísio tenta camuflar sua dependência vis-à-vis do seu modelo: ele muda um pouco a ordem das palavras, troca uma palavra por um sinônimo ou introduz passagens que encontra em outra obra de Proclo ou em outra fonte. Evidentemente, eliminou cuidadosamente todo traço de paganismo ou de politeísmo, e, para reforçar o caráter cristão da doutrina, introduziu algumas citações bíblicas. Em relação a seu modelo, Dionísio mostra muito pouca originalidade. E, o que é mais grave, parafraseando Proclo, ele arruinou a coerência e a clareza da argumentação do filósofo. De uma exposição clara e didática, ele fez um resumo confuso e obscuro, em que a articulação dos argumentos se perde. O que se tem, frequentemente, é um arranjo de teses sem nenhum encadeamento lógico necessário". Steel considera ainda que, no tratado sobre o mal, a contribuição do Pseudo Dionísio Areopagita é mínima, não passando de passagens tautológicas e frases banais e sem interesse filosófico, escritas num grego ruim e sem graça. "Se alguém se baseasse nesse texto para julgar Dionísio, precisaria dizer que ele não é um pensador original e que atesta, antes, um espírito confuso, incapaz de se exprimir." O artigo de Steel mostra a forma como o Pseudo Dionísio Areopagita utilizou o De malorum subsistentia, de que existe somente a tradução latina de Guilherme de Moerbeke, já que o original grego se perdeu. Nele, Proclo elenca os argumentos de filósofos favoráveis e contrários à ideia da existência real do mal no mundo. Em favor de sua doutrina, Dionísio aproveita apenas as teses contrárias, citando algumas das favoráveis como objeções à sua argumentação, que são logo respondidas. É curioso o empréstimo que ele faz de um recurso de Proclo. Este introduz as razões da existência do mal pedindo que os argumentos especulativos sejam primeiro confrontados com a realidade, o que confirmaria aquelas razões. O autor do Corpus toma expressão parecida - deve-se "ver a verdade das coisas" ( $\tau \cap \nu \pi \rho \alpha \gamma \mu \quad \tau \varpi v \quad \lambda \rightarrow \tau \varepsilon \iota \alpha \nu \quad \pi \mathrm{o} \beta \lambda \curlyvee \pi \varepsilon \imath v)$ - e a põe no início de suas considerações, para provar o contrário. Steel nota que, embora a posição de Dionísio tenha passado à história como uma visão de mundo típica do neoplatonismo, há nuances entre o pensamento do teólogo cristão e o do filósofo pagão, que tende a aceitar a ideia da existência do mal - embora considere que este depende do bem para se instalar. As críticas de Steel quanto aos trechos de Dos nomes divinos sobre o mal parecem desconsiderar que, neles, transparece menos o filósofo preocupado em expor argumentos racionais sobre a questão e mais o teólogo dedicado a apresentar uma realidade decorrente da ideia de que tudo foi criado pelo Bem e que, portanto, o mal não pode existir - para o que trechos de De malorum subsistentia viriam a calhar perfeitamente. A má vontade de Steel para com Dionísio talvez explique a contradição existente em seu artigo, que aponta nuances entre Dionísio e Proclo ao mesmo tempo em que afirma que o autor do Corpus "defende sem nenhuma reserva a mesma doutrina do mal de Proclo".

${ }^{71}$ Dos nomes divinos IV, 20. 
menos uma centelha da bondade divina, não teriam ser e, portanto, não existiriam. Segue-se daí que tudo quando existe é mais ou menos ser na medida em que participa do Bem. Isso vale para a matéria e o espírito, para o corpo e a alma. "A natureza não é má. O mal consiste na incapacidade que têm as coisas para alcançar o mais alto grau de perfeição a que estão chamadas."72

Sem essência nem existência, o mal tem como fundamento o bem, pois mesmo quando se pratica o mal é o bem a que se visa - como quando o salteador pratica um delito tendo em vista o prazer que o dinheiro roubado lhe proporcionará. "O mal, portanto, é privação, deficiência, debilidade, desordem, erro, irreflexão, ausência de formosura, de vida, de inteligência, de razão, de finalidade, de estabilidade, de perfeição, de fundamento, de causa., ${ }^{, 73} \mathrm{O}$ mal é ausência do Bem. E os homens que erram conscientemente, os que são débeis na fé, os que se recusam a praticar o bem esses confirmam que o mal é uma privação, uma falta de conhecimento, uma ignorância, uma incapacidade de atingir a perfeição.

Com Ser - outro nome como Deus é chamado em Dos nomes divinos -, o Pseudo Dionísio Areopagita quer dizer que o um é o puro ser e causa de todos os seres. Ele contém em si, de forma simples e indefinível, toda a Criação. "É o Ser dos seres"74, fundamento, princípio, conservação e finalidade de tudo. A essência das coisas se encontra nele: “Os arquétipos existem previamente em Deus como supraunidade. Ele é autor de todas as essências. O que chamamos arquétipos ou exemplares são em Deus as razões essenciais das coisas, que preexistem em Deus simplesmente.",75

Deus se diz Vida e Sabedoria, afirma ainda o Pseudo Dionísio Areopagita em Dos nomes divinos. É Vida porque concede a existência a todos os seres e é princípio de vida. E se chama Sabedoria porque é o autor e dispensador da razão, da inteligência e da sabedoria. Também porque, como Causa de tudo, conhece todas as coisas internamente, desde seu princípio e antes que começassem a existir. Deus não conhece as coisas a partir delas, mas a partir de si mesmo, como destaca o autor:

Assim também a Sabedoria divina conhece todas as coisas conhecendo a si
mesma. Conhece imaterialmente as coisas materiais, indivisivelmente as
coisas divisíveis, unitariamente os múltiplos. Porque tudo conhece e produz
com um só ato. Porque é certo que Deus, como Causa única e universal,
confere a existência a todos os seres, pela mesma razão conhecerá todo ser,
pois procede dele e preexiste nele. Não terá, portanto, que partir dos seres

\footnotetext{
${ }^{72}$ Dos nomes divinos IV, 26.

${ }^{73}$ Dos nomes divinos IV, 32.

${ }^{74}$ Dos nomes divinos V, 4.

${ }^{75}$ Dos nomes divinos V, 8.
} 
para chegar a conhecê-los, pois é Ele precisamente quem dá a cada um deles o poder de conhecer-se e de conhecer os demais. ${ }^{76}$

Tanto a simbologia de Da hierarquia eclesiástica como o discurso racional de Dos nomes divinos não são suficientes, porém, para atingir o pleno conhecimento de Deus, ser inefável, sustenta o Pseudo Dionísio Areopagita. Para isso, é preciso abandonar todo discurso, toda reflexão, todo sentido, deixar-se penetrar na "divina treva" e contemplar o um. Essa é a síntese de Da teologia mística, o quarto livro do Corpus dionysiacum.

A Timóteo ${ }^{77}$, a quem o livro é dedicado, o Pseudo Dionísio Areopagita exorta a "renunciar aos sentidos, às operações intelectuais, a todo sensível e ao inteligível", pois é através do livre, absoluto e puro despojamento de si mesmo e de todas as coisas que o homem se eleva espiritualmente até a divina Supraessência. "Despoja-te de todas as coisas que são e das que não são. Deixa de lado teu entender e esforça-te por subir o mais que puderes, até te unires com aquele que está mais além de todo o ser e de todo o saber."78

A subida de Moisés ao monte Sinai, registrada no Exxodo, é um exemplo de ascensão a Deus através da contemplação, como mostra Da teologia mística. O líder do povo hebreu, antes de entrar na presença do Todo-Poderoso, teve primeiro de se purificar e se afastar da multidão. Então, renunciando à razão e à sensação, penetrou nas misteriosas "trevas do não-saber" e se uniu ao incognoscível ${ }^{79}$.

Renunciar às visões e ao conhecimento é "a verdadeira visão e conhecimento". É o que torna possível ver e conhecer o invisível e incognoscível. Assim como os escultores retiram a envoltura que impede ver claramente a forma encoberta pela pedra, também os homens devem renunciar a todas as coisas para atingir o que está oculto aos sentidos.

Quanto mais próximo da divindade, menos palavras são necessárias, pois o inteligível se apresenta simples. Daí por que Da teologia mística é um livro tão curto, com apenas cinco pequenos capítulos. “À medida em que nos adentramos naquela obscuridade que o entendimento não pode compreender, ficamos não apenas sem

\footnotetext{
${ }^{76}$ Dos nomes divinos VII, 2.

77 Timóteo foi discípulo do apóstolo Paulo, para quem este escreveu duas cartas, que hoje compõem o Novo Testamento. Trata-se de mais um pseudônimo criado pelo autor.

${ }^{78}$ Da teologia mística I, 1.

${ }^{79}$ Da teologia mística I, 3.
} 
palavras, mas também em perfeito silêncio e sem pensar em nada." ${ }^{80}$ Ao tratar da teologia conceitual, em Dos nomes divinos, o discurso humano procede do mais alto ao mais baixo, onde as palavras se multiplicam, diz o autor. Já na teologia mística o movimento é o contrário: do mais baixo para o mais elevado. "Ao chegar lá em cima, reina um completo silêncio. Estamos unidos por completo ao Inefável.",81

A causa transcendente de todas as coisas - lembra o autor - não é sensível. Portanto, está inacessível à teologia simbólica, que busca conhecer Deus através das coisas visíveis. Também não é conceitual, o que a torna igualmente inatingível para o discurso racional dos teólogos. Nenhuma afirmação ou negação é capaz de explicar o que é simples e despojado de toda limitação. "Nada pode alcançá-lo.",82

Já quanto às dez cartas que compõem o Corpus dionysiacum, elas destacam principalmente temas tratados ao longo dos quatro livros. A Carta I, endereçada "ao monge Gaio",83, por exemplo, alerta que o saber humano é insuficiente para conhecer a ciência secreta de Deus. Na Carta IV, o perfil que se faz de Jesus Cristo pode ser usado a favor da ortodoxia do autor e contra as acusações de monofisismo que lhe são desferidas: ali Cristo é descrito como perfeitamente Deus e perfeitamente homem. "Sendo Ele supraessencial, é em si tudo o que é o homem." 84

A Carta VII é interessante por revelar explicitamente a postura do Pseudo Dionísio Areopagita diante da cultura grega, que, como se revela no Corpus, é assimilada pelo autor e se torna um instrumento útil para o conhecimento do Deus revelado pelas Escrituras cristãs. Endereçada a Policarpo, bispo de Esmirna ${ }^{85}$, ela cita que um certo sofista de nome Apolofanes chamara o autor da carta de "parricida", por usar a sabedoria grega contra os gregos e a favor dos cristãos. $\mathrm{O}$ autor responde que é mais correto dizer que são os gregos que se utilizam do que é divino para se voltar contra o Deus verdadeiro, pois deixam de reverenciá-lo valendo-se da sabedoria que o Criador lhes concede.

"Esse conhecimento do ser, que retamente chamam de filosofia e que são Paulo denomina 'sabedoria de Deus', devia ter levado os verdadeiros filósofos a se elevar até aquele que é causa não só dos seres, mas também do conhecimento que se pode ter dos

\footnotetext{
${ }^{80}$ Da teologia mística III, 1.

${ }^{81}$ Da teologia mística III, 1.

${ }^{82}$ Da teologia mística $\mathrm{V}, 1$.

${ }^{83}$ Gaio é o destinatário da terceira Carta de João, um dos textos do Novo Testamento.

${ }^{84}$ Carta IV.

85 Policarpo foi discípulo do apóstolo João e morreu como mártir, por volta do ano 160, vítima da perseguição romana aos cristãos.
} 
seres." ${ }^{86}$ Porém, fiel ao espírito grego de tolerância, o Pseudo Dionísio Areopagita sustenta que nunca travou polêmica "nem com gregos nem com ninguém",87. Para ele, a melhor aspiração que os homens podem ter é proclamar a verdade tal como ela é. No momento em que se demonstra claramente a verdade, o que é falso se desfaz, ainda que tenha aparência de verdade.

Deve-se registrar, porém, a desconfiança que, desde o surgimento de suas obras, o Pseudo Dionísio Areopagita despertou entre os cristãos ortodoxos. A acusação mais comum dirigida a ele se refere ao fato de ter introduzido no cristianismo a filosofia neoplatônica, com todos os seus equívocos e heresias. Entre estas se encontram uma angeologia muito distinta da que se depreende dos dois primeiros capítulos da Carta aos Hebreus e uma clara visão panteísta do Universo. Um moderno crítico de Dionísio afirma, por exemplo, que o autor de Dos nomes divinos é mais dependente das fontes neoplatônicas do que da fontes cristãs, embora preserve cuidadosamente a veste exterior da doutrina cristã ${ }^{88}$.

Outro autor, porém, têm uma visão diferente. Zéphirin Gonzalez, em sua Histoire de La Philosophie, reconhece que os textos de Dionísio dão margem à acusação de panteísmo, mas isso ocorre, segundo ele, quando certas passagens são lidas fora do seu contexto. "O sentido panteísta a que esses textos poderiam dar lugar tomados isoladamente, encontra-se excluído pelo contexto e pelo sentido geral do livro", afirma Gonzalez, referindo-se a Dos nomes divinos.

Outra acusação contra Dionísio diz respeito à dissimulação com que ele compôs sua obra, fazendo-se passar pelo areopagita do século I, convertido pelo apóstolo Paulo. Para os críticos, essa "fraude" seria mais uma indicação da pouca seriedade e nenhuma ortodoxia do autor do Corpus dionysiacum. Mas também nesse caso pode-se ter uma outra interpretação. Antes de tudo, deve-se lembra que o conteúdo dos livros - afinal, o que mais importa - é de uma profundidade irrecusável. Pode-se admitir também que o recurso ao pseudônimo famoso foi a forma encontrada pelo verdadeiro autor para tornar seus escritos mais conhecidos e lidos. Finalmente, deve-se dar ao Pseudo Dionísio Areopagita o crédito do bom humor, sempre tão necessário. No mais, lembre-se do que afirmou o filósofo alemão Josef Pieper, ao comentar justamente o fato de Dionísio ter "enganado" a cristandade durante um milênio. Para Pieper, "é preciso que se diga:

\footnotetext{
${ }^{86}$ Carta VII, 2.

${ }^{87}$ Carta VII, 1.

${ }^{88}$ Guido de Ruggiero, La filosofia del cristianesimo. Roma: Laterza, 1967, p. 365.
} 
deixou-se enganar". Ou seja, é possível que os autores medievais desconfiassem da "brincadeira", mas, diante da qualidade das obras, consideraram irrelevante saber quem era o verdadeiro autor dos textos dionisianos.

Seja como for, a postura de entusiasmada assimilação e aceitação da filosofia grega indica que, ao adotar como pseudônimo o nome do ateniense convertido por Paulo no Areópago, o autor do Corpus dionysiacum não fez uma escolha aleatória. Estão lá, no discurso do apóstolo registrado em Atos dos apóstolos, os principais elementos do pensamento do teólogo cristão do século $\mathrm{V}$ ou VI, de tão grande influência na teologia e na filosofia medieval.

O "Deus desconhecido" citado por Paulo, por exemplo, sugere a transcendência inatingível do Criador, uma ideia que permeia todo o Corpus. Diante da tendência humana de achar que pode conhecer e entender Deus, a obra do Pseudo Dionísio Areopagita está a lembrar que a separação entre o divino e o humano é absoluta e radical. Que a relação entre Deus e o homem é a mesma que se dá entre o Absoluto e o temporal, relativo e passageiro, entre o Todo e o nada. E não apenas o conhecimento de Deus é inatingível à compreensão humana, mas também a ciência mais profunda das coisas criadas, uma vez que suas essências se encontram naquele ser inacessível. É nesse sentido que se pode chamar o Pseudo Dionísio Areopagita de "o filósofo do nãosaber".

Porém, apesar desse profundo abismo existencial, o discurso de Paulo aponta para um relacionamento possível entre o homem e Deus, de quem os seres humanos são "geração", como disse o apóstolo, citando poetas gregos. Sendo gerados por Deus, os homens e todas as coisas estão ligados a Ele, têm participação nele e a Ele aspiram. Podem se aproximar dele por meio das coisas sensíveis (as imagens, cerimônias e cânticos) e dos conceitos abstratos (as doutrinas e o discurso teológico) e, através da contemplação mística, chegar à perfeita união com o divino.

Até mesmo a atitude de Paulo de conciliar a filosofia grega e o cristianismo é imitada pelo Pseudo Dionísio Areopagita, do que dá testemunho todo o Corpus. Em suas obras, o autor, ao invés de considerar o pensamento pagão uma visão de mundo oposta às Escrituras, aproveita esse saber para ir além dele e revelar coisas ainda desconhecidas pelos homens. Não destrói nada, mas constrói a partir do que os filósofos já conceberam. Foi essa a mesma postura de Paulo, para quem o Altar do Deus Desconhecido se tornou não um oratório pagão a ser combatido, mas uma oportunidade para anunciar o verdadeiro Deus. 
Acrescente-se o espírito de tolerância e liberdade de pensamento, típico da tradição clássica grega, tão presente no Corpus e cultivado pelos ouvintes de Paulo, os areopagitas. Conceitos das principais correntes filosóficas e religiosas da época - do neoplatonismo e do aristotelismo ao judaísmo e ao cristianismo, dos oráculos caldeus ao gnosticismo - se encontram harmonizados na obra do Pseudo Dionísio Areopagita, que com maestria os une e reveste de um sentido cristão. Dá continuidade, assim, à ideia de que a verdade sobre o Criador não está apenas nas Sagradas Escrituras, mas pode ser encontrada também na obra dos filósofos pagãos ${ }^{89}$, que, segundo o favor de Deus, alcançaram pela razão centelhas da luz divina ${ }^{90}$ - revelações que podem igualmente ajudar os homens a conhecer e a reverenciar a Causa e o Fim de todas as coisas.

\footnotetext{
${ }^{89}$ Essa ideia teve como pioneiro o filósofo cristão Justino (100-165), para quem "tudo o que de verdade se disse pertence a nós, os cristãos" (Segunda apologia XIII).

${ }^{90}$ Como afirma o poeta francês Lamartine (1790-1869), no poema "Dieu": "Eis aí, eis aí o Deus que todo espírito adora,/ Que Abraão serviu, de quem Pitágoras cogitou/ Que Sócrates anunciou, que Platão presentiu;/ Esse Deus que o universo revela à razão,/ Que a justiça aguarda,/ que o infortúnio espera,/ E que o Cristo enfim vem mostrar à terra!/ Esse não é esse Deus fabricado pelo homem,/ Esse Deus explicado pelo embuste ao erro,/ Esse Deus desfigurado pela mão dos falsos sacerdotes,/ Que adoraram, tremendo, nossos crédulos ancestrais/ Ele é único, ele é um, ele é justo, ele é bom;/ A terra vê sua obra e o céu conhece o seu nome!": (Voilà, voilà le Dieu que tout esprit adore,/ Qu'Abraham a servi, que rêvait Pythagore,/ Que Socrate annonçait, qu'entrevoyait Platon;/ Ce Dieu que l'univers revele à la raison,/ Que la justice attend, que l'infortune espere,/ Et que lê Christ enfim vint montrer à la terre!/ Ce n'est plus là ce Dieu par l'homme fabriqué,/ Ce Dieu par l'imposture à l'erreur expliqué,/ Ce Dieu défiguré par la main des faux prêtres,/ Qu'adoraient en tremblant nos crédules ancêtres/ Il est seul, il est um, il est juste, il est bom;/ La terre voit son oeuvre, et le ciel sait son nom!" (Lamartine, Méditations poétiques, Paris, Garnier, 1950, p. 76).
} 


\section{DO CRISTIANISMO MEDIEVAL À TEOLOGIA CONTEMPORÂNEA}

Ao longo de cerca de mil anos, desde o seu surgimento, no início do século VI, até o século XVI, a obra do Pseudo Dionísio Areopagita exerceu profunda influência na sociedade europeia. A teologia, a filosofia, a religião e as artes, naquele período, foram moldadas em boa medida pelo pensamento do autor que se fazia passar pelo cristão convertido pelo apóstolo Paulo.

Logo o Corpus dionysiacum atraiu a atenção dos primeiros comentadores, inicialmente no Oriente ${ }^{91}$. Na Síria, ainda no século VI, surgiram uma tradução dos quatro tratados e das dez cartas para o sírio, feita por Sérgio de Reishaina, e os scholia de João de Citópolis. Um século depois, Máximo, o Confessor (580-662), nascido em Constantinopla, escreveu três obras - intituladas Scholia, Ambígua e Mystagogia - que expunham uma visão ortodoxa das obras do Pseudo Dionísio Areopagita, livrando-o das acusações de monofisita e apolinarista.

Esse sucesso inicial no Oriente não pode sequer ser comparado com a fortuna das obras do Pseudo-Dionisio Areopagita no Ocidente, onde elas tiveram uma aceitação ainda maior. Na Europa, o Corpus dionysiacum foi citado pela primeira vez por Gregório Magno (540-604), papa desde 590, que havia passado seis anos em Constantinopla. Em suas homilias, Gregório cita Da hierarquia celeste, Dos nomes divinos e Da teologia mística e classifica seu autor de "antigo e venerável mestre". Escreveu um tratado sobre os anjos claramente sob influência dionisiana. Por tudo isso, suspeita-se que Gregório tenha levado um manuscrito do Corpus para Roma, após a passagem por Constantinopla. É certo, pelo menos, que em 649 havia um códice com esses escritos na biblioteca pontifícia, conforme as atas do concílio Lateranense, convocado pelo papa Martinho I e realizado naquele ano.

Outros papas citaram o Corpus dionysiacum nos dois séculos seguintes: Agatão, em 680, em carta enviada ao IV Concílio de Constantinopla, e Adriano I, em 787, em mensagem ao II Concílio de Niceia. Em pelo menos três ocasiões, os livros foram

\footnotetext{
${ }^{91}$ Boa parte das informações contidas neste capítulo foi extraída da introdução de Teodoro H. Martin em Obras completas del Pseudo Dionísio Areopagita, Madrid, Biblioteca de Autores Cristianos, 1990.
} 
usados para combater os iconoclastas: em 731, sob o papa Gregório III, em 769, sob Estevão III, e em 825, sob Eugênio II. Em 758, o papa Paulo I presenteou Pepino, o Breve, rei dos francos, com um exemplar do Corpus.

Mas o marco decisivo que determina a entrada definitiva do Corpus dionysiacum no Ocidente ocorreu no século IX. Esse acontecimento tem data e local conhecidos. Ele se deu em 8 de outubro de 827, quando a abadia de Saint-Dennys, em Paris, recebeu solenemente os manuscritos do Pseudo Dionísio Areopagita, oferecidos pelo imperador bizantino Miguel II, o Gago, a Ludovico, o Pio, filho e sucessor de Carlos Magno ${ }^{92}$. Na época, o autor dos livros foi confundido com Dionísio, o primeiro bispo de Paris, que viveu no século III e dá nome à abadia de Saint-Dennys.

Coube a Hilduíno, abade de Saint-Dennys, a tarefa de realizar a primeira tradução do Corpus dionysiacum para o latim. Concluída em 835, ela ficou muito ruim, provavelmente devido ao método de tradução empregado na obra. Como revelou G. Théry ${ }^{93}$, o abade parece ter se servido de um auxiliar que ditava o grego e outro que escrevia em latim o texto traduzido e reproduzido em voz alta por Hilduíno. Isso gerou muitos erros e tornou a tradução quase ilegível.

Carlos II, o Calvo, sucessor de Ludovico, solicitou uma nova tradução do Corpus ao filósofo irlandês João Escoto Erígena (810-877), que a apresentou em 862. Erígena foi mais do que tradutor. Entusiasmado com o pensamento exposto no Corpus, o filósofo irlandês se transformou no primeiro grande divulgador do Pseudo Dionísio Areopagita no Ocidente. A influência dionisiana é nítida nas suas obras, especialmente na mais importante delas, Da divisão da natureza, um tratado sobre a origem e desenvolvimento do mundo.

Embora tenha sido vista como herética, a obra de Erígena tornou o pensamento dionisiano conhecido da Escolástica. A Escola de Chartres, em Paris, cultiva o pensador desde o seu início, em torno do ano $1000^{94}$. No século XII, o Pseudo Dionísio Areopagita é citado pelos principais filósofos e teólogos da época, entre eles, Pedro Lombardo. Em 1165, João Sarraceno, monge de Saint-Dennys, fez nova tradução do Corpus, elogiada por sua ortodoxia, que será muito utilizada no século seguinte pelos principais autores escolásticos.

\footnotetext{
${ }^{92}$ Esse exemplar do Corpus dionysiacum está guardado atualmente na Biblioteca Nacional de Paris, sob o número 437.

${ }_{93}$ Études dionysiennes, volume I, 1932.

${ }^{94}$ T. H. Martin cita uma carta escrita em 1003 pelo fundador da Escola de Chartres, Fulbert, em que ele cita uma expressão tipicamente dionisiana, "superessentia Deitatis" (obra citada, p. 21).
} 
Hugo de São Vitor (1096-1141), da escola de São Vitor, em Paris, também se dedicou a estudar o Corpus. Assim descreve T. H. Martin:

\begin{abstract}
O comentário de Hugo a Da hierarquia celeste é a melhor prova da ascensão que Dionísio ia adquirindo no início da Escolástica. Hugo preferiu essa obra às demais por duas razões: a forte ideia que contém de participação divina e o método de teologia simbólica que expressa a gradação angélica. Ele o aplica ao crescimento da alma na vida interior. Serve-se do neoplatonismo da obra para se aprofundar a dimensão psicológica de Santo Agostinho frente à ontologia 'perigosa' de João Scoto. ${ }^{95}$
\end{abstract}

Thomas Gallus e Gilberto de Poitiers, ambos da Escola de Chartres, também leram as obras dionisianas. Estas, é certo, estavam presentes no famoso monastério cisterciense de Claraval, fundado em 1115 por Bernardo de Claraval, e foram estudadas ainda pelo cisterciense inglês Isaac de Stella. Boaventura (1221-1274) chegou a dizer do Pseudo Dionísio Areopagita, a quem considerava "o príncipe dos místicos": "O que Santo Agostinho é para o dogma e São Gregório é para a moral, São Dionísio é para a mística: o mestre inquestionável"96.

No século XIII, na Inglaterra, o inglês Robert Grosseteste (1168-1253), bispo de Lincoln, publicou uma nova tradução do Corpus, considerada clara e fiel ao original, além de escrever comentários sobre a obra dionisiana. Roger Bacon, Thomas de York e John Wycliff foram leitores do trabalho de Grosseteste. O interesse pelo Pseudo Dionísio Areopagita na Inglaterra foi tanto que produziu um livro hoje anônimo, The cloud of unknowing - obra máxima da mística inglesa do século XIV -, muito semelhante ao Corpus no estilo e no conteúdo.

Já em Paris, o Corpus dionysiacum foi acolhido por um pensador que faria com que a obra dionisiana atingisse a mais alta consideração entre os escolásticos: Alberto Magno (1206-1280), que escreveu comentários sobre os quatro livros dionisianos. Com eles, Alberto quis fazer um contraponto ao intelectualismo aristotélico vigente na época, além de reforçar o psicologismo agostiniano, segundo T. H. Martin ${ }^{97}$.

Certamente o esforço de Alberto Magno despertou a atenção de seu mais ilustre discípulo, Tomás de Aquino (1224-1274), para o pensamento do Pseudo Dionísio Areopagita. Tomás cita o Corpus 1.702 vezes ao longo de sua obra. Utilizando a tradução de João Sarraceno, comentou Dos nomes divinos e, de resto, tem seu pensamento marcado por Dionísio. Tomás constrói sobre estruturas aristotélicas, mas

\footnotetext{
${ }^{95}$ T. H. Martin, obra citada, p. 21.

${ }^{96}$ Citado por T. H. Martin, obra citada, p. 21.

${ }^{97}$ Obra citada, p. 24-25.
} 
correm por sua obra veias de neoplatonismo dionisiano, acrescenta T. H. Martin, que continua:

\begin{abstract}
O plano geral e estrutura da Suma teológica está feito sobre as linhas mestras do Pseudo-Dionísio: saída e retorno (exitus-reditus), mundo destacado em círculo que começa e termina na unidade de Deus (...).

Não cabe a menor dúvida de que em Santo Tomás há uma influência 'causal' do Areopagita, ou seja, de verdadeira forma e conteúdo, não só ocasional ou de léxico e fórmulas. Ele chega a trocar expressões de Dionísio, dando novas palavras às mesmas ideias. ${ }^{98}$
\end{abstract}

Como já apontara Boaventura, o Pseudo Dionísio Areopagita é o "príncipe dos místicos" cristãos. Afastando-se da tendência racionalista que, desde Santo Agostinho (354-430) e Boécio (480-524), acompanha o cristianismo, ele inaugurou uma forma de se relacionar com Deus que marcará a vida e a obra dos grandes místicos medievais e modernos. A começar de Mestre Eckhart (1260-1327), que aprofunda ainda mais as teses dionisianas e lhe acrescenta novas ideias, e de Jan van Ruusbroec (1293-1381), que, por causa de sua "sabedoria excelentíssima", foi chamado de "outro Dionísio"99.

Juan de la Cruz (1542-1591), o grande místico espanhol do século XVI, também foi marcado pela teologia dionisiana. Isso pode ser notado, por exemplo, no método negativo que utiliza para se referir a Deus e para conhecer as coisas divinas. Nunca o mar infinito de Deus poderá encerrar-se nos aquedutos da linguagem humana, afirma Juan de la Cruz. O cristão precisa se despojar dos modos como o entendimento humano pretende conhecer Deus e seu infinito amor. Toda representação intelectual é reflexo da luz divina, que evidencia que Deus é muito maior do que tudo e não é nada do que existe. Tais concepções são claramente dionisianas, assim como este parágrafo de uma das obras do místico espanhol:

\begin{abstract}
Dirás que não entendes nada distintamente e assim não poderás ir adiante. Antes te digo que, se entendesses distintamente, não irias adiante. A razão é que Deus, a quem se dirige o entendimento, excede o entendimento. Assim, é incompreensível e inacessível ao entendimento e, portanto, quando o entendimento entende, não chega a Deus, e sim se afasta. E, assim, é necessário afastar o entendimento de si mesmo e de sua inteligência para chegar a Deus, caminhando em fé, crendo e não entendendo. Dessa maneira o entendimento chega à perfeição, porque por fé e não por outro meio se une a Deus, e a Deus mais se chega a alma não entendendo do que entendendo. ${ }^{100}$
\end{abstract}

Os humanistas do Renascimento acolheram o Pseudo Dionísio Areopagita até com entusiasmo. Nicolau de Cusa (1401-1464) traduz a teologia negativa dionisiana em

\footnotetext{
${ }^{98}$ T. H. Martin, obra citada, p. 26-27.

${ }^{99}$ A expressão é de Dionísio, o Cartuxo. Citado por T. H. Martin, obra citada, p. 27.

${ }^{100}$ Juan de la Cruz, Llama 3, 48. Citado por T. H. Martin, obra citada, p. 41.
} 
"douta ignorância", título de seu mais influente livro. Entregando-se a Deus, circunferência em que giram todas as criaturas e centro de convergência universal, a mente se torna o ponto de simplicidade de onde emergem a espiritualidade angélica e a corporeidade de todas as coisas, diz o cardeal alemão.

Marsílio Ficino (1433-1499) considerava o Pseudo Dionísio Areopagita "o maior dos teólogos" e ainda "o cume da teologia cristã e da filosofia platônica". O diretor da Academia de Florença, que traduziu e comentou Dos nomes divinos e Da teologia mística, julgava que o autor do Corpus era superior até mesmo a Platão. "Se é certo que Dionísio era discípulo de Platão como piedoso filósofo, cremos que deve ser preferido não só aos outros platônicos, pela sublimidade de sua doutrina, mas também ao próprio Platão, pela nova luz da verdade cristã", escreveu Ficino ${ }^{101}$. Por tudo isso, afirma T. H. Martin, Dionísio, graças a Marsílio Ficino e aos humanistas da Academia florentina, veio a ser o modelo de humanismo integral ${ }^{102}$.

Ainda no século XV, o latinista Ambrosio Traversari (1386-1439) fez uma nova tradução do Corpus dionysiacum, apresentada em 1436. Impressa em 1480 em Bruxelas, chegou a ser o texto mais difundido na Europa.

A Reforma protestante do século XVI não sentiu o mesmo entusiasmo pelo autor de Dos nomes divinos. Zwinglio negou autoridade ao Corpus depois das publicações de Erasmo de Roterdã, que apontavam a impossibilidade de ter sido produzido no século I. Melanchthon criticou os ensinamentos de Da hierarquia eclesiástica no que se refere aos sacramentos e às práticas da Igreja. Já Calvino via em Da hierarquia celeste uma pretensiosa tentativa de saber mais do que Deus quis revelar. Sobre o primeiro livro do Corpus dionysiacum, Calvino escreveu:

\footnotetext{
Ninguém negará que esse Dionísio, quem quer que ele haja sido, arguira muitas coisas com sutileza e argúcia em sua obra Da hierarquia celeste. Se, no entanto, alguém a examina mais intimamente, verificará que na absolutamente maior parte é mero palavreado. Ao teólogo, porém, o propósito não é deleitar os ouvidos com o arguir loquazmente, mas firmar as consciências ensinando o verdadeiro, o certo, o proveitoso. Se lês esse livro, pensarás que um homem caído do céu está a referir não coisas que aprendeu, mas o que com os olhos viu. Paulo, entretanto, que fora arrebatado além do terceiro céu, não somente não referiu nada que tal mas, ao contrário, até deu testemunho de que não é lícito ao homem contar os segredos que vira. Portanto, feitas as despedidas a esse frívolo saber, consideremos dos simples ensinos das Escrituras o que o Senhor quis saibamos nós acerca de seus anjos. ${ }^{103}$
}

\footnotetext{
${ }^{101}$ Citado por T. H. Martin, obra citada, p. 33.

102 T. H. Martin, obra citada, p. 33.

103 João Calvino, Instituição da religião cristã I, XIV, 4, tradução de Waldyr Carvalho Luz, Casa Editora Presbiteriana, São Paulo, 1989, p. 181.
} 
Lutero, por sua vez, é o mais ambíguo dos reformadores no que diz respeito à sua posição sobre o Pseudo Dionísio Areopagita. Na juventude, o monge agostiniano tinha os livros de Dionísio entre os seus preferidos e os citava com frequência. Em textos que produziu nessa época, aparecem expressões como "teologia negativa", "êxtase" e "divina treva", de origem claramente dionisiana.

Após a eclosão da Reforma, porém, a visão de Lutero é outra. Agora ele critica o autor do Corpus devido à influência da filosofia grega pagã. Numa frase famosa, ele afirma: "Dionísio é muito prejudicial: mais do que cristianizar, ele platoniza". Em 1537, ele escreve: "Eu também estive algum tempo nesse campo (...). Agora te advirto que deves evitar a praga da Teologia mística de Dionísio e livros desse estilo, que só servem para perder tempo". 104

Com a oposição dos reformadores, a fama e a autoridade do Pseudo Dionísio Areopagita decresceram. Mesmo assim, suas obras não deixaram de ser comentadas nos séculos seguintes, principalmente na França, um tradicional reduto da devoção àquele teólogo. Ali surgiram, entre os séculos XVII e XVIII, grandes comentadores de Dionísio, como Benoît de Canfield, Pierre de Bérulle, Léonard Lessius, Louis Chardon e François Fénelon.

Nos séculos XIX e XX não aconteceu diferente: apesar da confirmação científica de que o Corpus não foi composto pelo discípulo do apóstolo Paulo, os admiradores de Dionísio continuaram a produzir estudos sobre sua obra. Alguns desses autores são J. Dulac, R. Roques e M. Gandillac, na França, J. Stiglmayr, E. Ivanka e Hans Urs von Balthasar, na Alemanha, e P. Scazzoso e V. Gamba, na Itália, entre vários outros.

No Brasil, as primeiras referências ao Pseudo Dionísio Areopagita talvez tenham sido as do padre Antônio Vieira (1608-1697). Em seus sermões, podem-se encontrar pelo menos oito citações que dizem respeito ao autor de Dos nomes divinos. Vieira expressa muita admiração por Dionísio, que ele acredita ser mesmo o membro do Areópago de Atenas convertido através do discurso de Paulo. No Sermão de Nossa Senhora do Ó, ele chama "S. Dionísio Areopagita" de "o mais alumiado de todos os teólogos"105. Em outro sermão, citando os livros que considera "cheios de divina e celestial doutrina", ele relaciona os escritos "dos antiquíssimos padres Clemente Romano, Dionísio Areopagita, Erineu, Justino"106. Vieira comenta o discurso de Paulo

\footnotetext{
${ }^{104}$ Citado por T. H. Martin, obra citada, p. 53.

105 Antônio Vieira, Sermão de Nossa Senhora do Ó I.

${ }^{106}$ Antônio Vieira, Sermão de todos os santos VII.
} 
no Areópago e a conversão de Dionísio ${ }^{107}$, fazendo referência, no mesmo trecho, ao eclipse que o suposto discípulo do apóstolo diz ter presenciado em Heliópolis ${ }^{108}$.

Pode-se perceber, ainda, um perfil mais místico do grande orador português, que busca a semelhança com Cristo - misticismo fundamentado no autor do Corpus dionysiacum, como no parágrafo seguinte:

\begin{abstract}
Isto é o que obra a memória só com a simples apreensão dos mistérios. E o entendimento, que faz? Olha para eles com grande consideração meditandoos, e por meio desta vista considerada e atenta se assemelha ao que vê, que é o efeito da segunda decocção. Assim o diz e ensina S. Dionísio Areopagita: Aperiet enim, si communionem ejus cupimus, in vitam ejus, quam incarne vixit, intueri, et similitudine sanctitatis ad habitum divinae virtutis recurrere. Notai a palavra intueri e a palavra similitudine, porque da vista com que o entendimento na comunhão medita os mistérios de Cristo, nasce a semelhança com que, alterando-se a alma, isto é, mudando-se em outra, os retrata em si, e se assemelha a eles. ${ }^{109}$
\end{abstract}

Uma menção deve ser feita à influência do Pseudo Dionísio Areopagita sobre as artes. A começar da obra máxima de Dante Alighieri (1265-1321), A divina comédia. Esta se encontra estruturada de acordo com a visão hierárquica do mundo exposta no Corpus dionysiacum. Conduzido por Virgílio, Dante faz o caminho de ascensão aos céus, partindo do mais profundo do inferno, onde nenhuma luz brilha, até a plena luz, os céus, onde desponta sua musa inspiradora, Beatriz.

Ao longo do caminho - e de sua obra-prima -, Dante expõe ideias cuja origem é inquestionavelmente a obra do Pseudo Dionísio Areopagita. Por exemplo, ele afirma que "a natureza tem origem no Divino Intelecto e em sua arte"110. Diz também: "Doido é quem considera a razão humana capaz de apreender a infinita grandeza onde vige o ente que é uno em três substâncias" ${ }^{111}$. Fala da hierarquia dos nove céus que, segundo sua concepção orientada pelo sistema ptolomaico do universo, giram em torno da Terra: “Como poderás verificar, esses órgãos do mundo obedecem, em geral, a uma regra invariável: recebem influxos dos imediatamente superiores e transmitem-nos aos imediatamente inferiores" ${ }^{\prime 12}$. E, no início da terceira parte, o Paraíso, Dante exclama:

A glória d'Aquele que é a origem de todas as coisas manifesta-se em todo o universo, em algumas partes resplandecendo mais, e menos em outras. ${ }^{113}$

\footnotetext{
${ }^{107}$ Antônio Vieira, Sermão de Santa Catarina VII.

${ }^{108}$ Carta VII, 2.

109 Antônio Vieira, Sermão Nossa Senhora do Rosário com o Santíssimo Sacramento IV.

${ }^{110}$ Dante, A divina comédia I, Canto XI.

111 A divina comédia II, Canto III.

${ }^{112}$ A divina comédia III, Canto II.

${ }^{113}$ A divina comédia III, Canto I.
} 
O espírito dionisiano está presente não somente na poesia, mas também no teatro e na pintura, entre outras manifestações artísticas. Gil Vicente (1465-1536) faz de Dionísio Areopagita personagem de seu Auto da paixão e as obras de Fra Angélico (1387-1455) e de El Greco e (1541-1614) estão tomadas pelo misticismo e pela teologia negativa do Corpus.

As breves análises feitas neste capítulo são suficientes para mostrar a importância do pensamento do Pseudo-Dionísio para a teologia, para a filosofia e até para a arte. Muitas vezes, essa influência, embora clara, não é percebida ou não é declarada por aqueles que a recebem. Recentemente, por exemplo, num artigo publicado na imprensa, o cardeal-arcebispo de São Paulo, Dom Odilo Pedro Scherer, escreveu, sem se referir ao autor do século VI: "O ser humano é chamado a participar da vida em Deus, fonte do ser e da existência, para receber de sua misericórdia a plenitude da vida" ${ }^{\prime 14}$. Frase que é síntese de boa parte da teologia de Dionísio: o homem é impelido naturalmente a fazer o caminho de ascensão a Deus, origem única de todas as coisas, em quem encontra o máximo bem. O Pseudo Dionísio Areopagita ainda fala ao homem contemporâneo.

\footnotetext{
${ }^{114}$ Dom Odilo Pedro Scherer, "O drama da morte e o sentido da vida", jornal O Estado de S. Paulo, 10 de novembro de 2007, página A2.
} 


\section{NEGATIVIDADE E PARTICIPAÇÃO NO CORPUS DIONYSIACUM}

O pensamento do Pseudo Dionísio Areopagita é uma especulação sobre coisas que não pertencem nem ao mundo sensível nem ao domínio do conhecimento inteligível. É nessa esfera - não material, intelectual ou espiritual - que se instala o que é impossível nomear, mas que nem por isso deixa de existir. Os quatro tratados e as dez cartas que formam o Corpus dionysiacum são justamente o reconhecimento de uma realidade radicalmente transcendente, sequer percebida ou imaginada pelos homens. Deus, Criador, Trindade - nomes utilizados para se referir a essa realidade absolutamente incompreensível - são expressões inadequadas, úteis apenas para sugerir que existe algo além da capacidade de apreensão humana.

Essa realidade incompreensível permanece incognoscível. Isso torna evidente a limitação do conhecimento humano no que se refere à realidade transcendente. Lembrando que, conforme as Escrituras, "ninguém jamais viu Deus",115, o Corpus dionysiacum destaca que o Criador é "um mistério que transcende todo ser", supraessencial a todas as coisas, e que, definitivamente, nada do que existe pode ser comparado a ele ${ }^{116}$. Não existem palavras que possam expressar esse Bem inefável ${ }^{117}$. Nenhuma criatura pode conhecê-lo nem contemplá-lo como é, uma vez que ele transcende tudo, e não há caminhos por onde penetrar em sua infinitude secretíssima ${ }^{118}$.

Sendo causa de todas as coisas, Deus não é nada do que existe, pois está supraessencialmente separado de todo ser. "Está muito longe de qualquer maneira de ser, de todo movimento, vida, imaginação, opinião, nome, palavra, pensamento, inteligência, substância, estado, princípio, união, fim, imensidade. De tudo quanto existe." 119

\footnotetext{
${ }^{115}$ I Timóteo VI, 16: "o único que possui imortalidade, que habita em luz inacessível, a quem homem algum jamais viu nem é capaz de ver".

${ }_{116}^{116}$ Da hierarquia celeste XII, 3.

${ }^{117}$ Dos nomes divinos I, 1.

${ }^{118}$ Dos nomes divinos I, 2.

${ }^{119}$ Dos nomes divinos I, 5.
} 
As realidades secretas de Deus são incomunicáveis, mais profundas do que um abismo, continua o Pseudo Dionísio Areopagita ${ }^{120}$. Ele é Ser que está sobre todo ser, sem que nada o alcance ${ }^{121}$. Não é possível designar seu nome nem seu modo de ser, pois se eleva muito acima de todo entendimento. É um mistério muito distante da realidade das coisas ${ }^{122}$, uma luz inacessível que, por sua claridade imensa, se transforma numa impenetrável treva divina ${ }^{123}$. O Pseudo Dionísio Areopagita acentua a inacessibilidade de Deus, afirmando:

Dizemos, pois, que a Causa universal está por cima de todo o criado. Não carece de essência nem de vida nem de razão nem de inteligência. Não tem corpo nem figura nem qualidade nem quantidade nem peso. Não está em nenhum lugar. Nem a vista nem o tato a percebem. Não sente nem a alcançam os sentidos. Não sofre desordem nem perturbação procedente de paixões terrenas. Não carece de poder nem a alteram acontecimentos imprevistos. Não necessita de luz. Não experimenta mutação nem corrupção nem decaimento. Não se lhe acrescenta ser nem fazer nem coisa alguma que caia sob o domínio dos sentidos. ${ }^{124}$

Deus envolve os seres de tal forma que a mente não pode compreender ${ }^{125}$. Nada consegue explicar o que é supraessencial a todo ser e que excede toda razão e inteligência $^{126}$. Trata-se de uma "ciência secreta" que nem a luz física nem o conhecimento das coisas sensíveis consegue apreender ${ }^{127}$, como diz o autor do Corpus dionysiacum:

O mistério de Jesus está escondido. Não há palavra nem entendimento que o descubram. Inefável por mais que dele digam. Ainda que o entendam, permanece incompreensível. $^{128}$

Para o Pseudo Dionísio Areopagita, nenhuma palavra ou conceito - produto do conhecimento do homem - é capaz de expressar as coisas divinas. O intelecto humano visa a conhecer um objeto, que é um ente, um ser. Uma vez que Deus - causa da inteligência e do conhecimento e criador da sabedoria universal e $\operatorname{particular}^{129}$ - é uma realidade que se eleva muito acima dos seres, segue-se que Ele transcende todo conhecimento. Para conhecê-lo, seria preciso um saber supraessencial ${ }^{130}$. "Não

\footnotetext{
${ }^{120}$ Dos nomes divinos II, 4.

${ }^{121}$ Dos nomes divinos II, 10.

${ }^{122}$ Dos nomes divinos XIII, 3.

${ }^{123}$ Carta 5.

${ }^{124}$ Da teologia mística IV.

${ }^{125}$ Dos nomes divinos IX, 9.

${ }^{126}$ Dos nomes divinos, XIII, 3.

${ }^{127}$ Carta 1.

${ }^{128}$ Carta 3.

${ }^{129}$ Dos nomes divinos VII, 1.

${ }^{130}$ Dos nomes divinos I, 1 e 4.
} 
podemos alcançar com o pensamento nem com palavras o um, o incognoscível, o supraessencial.",131

Não convém empregar a razão, que é uma "auxiliar dos sentidos", para chegar à secreta causa de todas as $\operatorname{coisas}^{132}$. Comparado com a inteligência divina, o entendimento humano é uma espécie de erro ${ }^{133}$, razão por que os mistérios da Trindade não devem ser entendidos conforme nenhuma das formas de pensar humanas ${ }^{134}$. $\mathrm{O}$ máximo que se pode obter com o intelecto é compreender que foi concedido ao homem participar da paternidade e filiação divinas ${ }^{135}$.

Em virtude dessa definitiva e radical incognoscibilidade do divino, é melhor se referir a Deus dizendo o que ele não é do que afirmando o que ele é, afirma o Pseudo Dionísio Areopagita. "Essa maneira é muito mais própria falando de Deus, pois, como a secreta tradição nos ensina, nada de quanto tem existido se parece com Deus e desconhecemos sua supraessência invisível, inefável, incompreensível.”,136

Usar palavras para se referir a Deus significa limitar aquele que é ilimitado e infinito. Ao chamá-lo de Ser, Vida, Luz e Verbo, por exemplo, apreendem-se apenas algumas propriedades do divino ${ }^{137}$. A Afirmação positiva é sempre inadequada para se referir ao mistério inexprimível ${ }^{138}$, daí porque, para chegar a Deus, o homem precisa abandonar toda operação intelectual ${ }^{139}$. Ascender à verdade através da negação libera a alma de tudo que lhe é afim na ordem natural, preparando-a para o desconhecido. "Por fim, transcendendo as fronteiras do mundo, a alma chega à união com Deus, tanto quanto é possível da parte dele como da parte da alma."140

Em Da teologia mística encontra-se delineado esse método de falar de Deus através da negação, em contraposição ao procedimento de fazer afirmações sobre ele. Afirmar, para o Pseudo Dionísio Areopagita, é partir do princípio das coisas e ir acrescentando-lhe afirmações, até chegar aos extremos, à totalidade do que se pode falar sobre esse princípio. Já com a negação se dá o contrário: a partir dos extremos, vão-se retirando as afirmações até chegar ao cume do desconhecido, onde não há palavras nem

\footnotetext{
${ }^{131}$ Dos nomes divinos I, 5.

${ }^{132}$ Dos nomes divinos VI, 2.

${ }^{133}$ Dos nomes divinos VII, 1.

${ }^{134}$ Dos nomes divinos XIII, 3.

${ }^{135}$ Dos nomes divinos II, 8.

${ }^{136}$ Da hierarquia celeste II, 3.

${ }^{137}$ Dos nomes divinos II, 7.

${ }^{138}$ Da hierarquia celeste II, 3.

${ }^{139}$ Dos nomes divinos II, 7.

${ }^{140}$ Dos nomes divinos XIII, 3.
} 
reflexão. Elimina-se, assim, tudo o que envolve o princípio das coisas - e impede o seu conhecimento pelos homens -, para chegar à união com o incognoscível. É como fazem os artistas ao esculpir uma estátua: lapidam o mármore, tirando da peça lascas de pedra que impedem ver a beleza da forma que desejam criar. ${ }^{141}$ Como está escrito em $\mathrm{Da}$ teologia mística:

\begin{abstract}
Quanto mais olhamos para cima, mais os discursos se contraem pela contemplação das coisas inteligíveis; assim também, agora, ao penetrarmos na treva superior do intelecto, já não encontramos discursos breves, mas uma total ausência de palavras e de pensamentos. Ao contrário, seguindo de cima para baixo, o discurso se amplia na proporção da descida; agora, todavia, elevando-se de baixo para cima, contrai-se na proporção da subida, tornandose profundamente mudo, para unir-se totalmente ao inefável. ${ }^{142}$
\end{abstract}

A Carta I volta ao tema da negação afirmando que os conhecimentos humanos tornam invisível a ciência do não-saber. Quanto mais luzes, menos visível é a treva divina. Ressalvando que o não-saber não significa privação, mas transcendência, o Pseudo Dionísio Areopagita diz:

Ele (Deus) ultrapassa todo ser e conhecer. Seu ser está acima de todo ser. A mente não alcança conhecê-lo. Negando a ele, pois, existência como a nossa, negando que nosso conhecimento o conhece, esse perfeito não-saber, no melhor sentido, é conhecer aquele que está acima de quanto se possa conhecer. $^{143}$

Mas, embora incognoscível, essa realidade indizível pode ser objeto de especulação. Para o autor do Corpus dionysiacum, Deus é a causa de todas as coisas. Ele estabeleceu a essência dos seres e lhes deu a existência ${ }^{144}$. Origem, essência e vida de tudo, é o princípio supraessencial de todo princípio ${ }^{145}$. Nada pode existir sem que dependa de algum modo daquele que é fonte de todo $\operatorname{ser}^{146}$. Dele procedem a eternidade e o tempo ${ }^{147}$. Nele os seres encontram seu princípio, conservação e finalidade ${ }^{148}$. Ele limita a expansão do ar, faz a terra descansar sobre o nada e produzir ricamente ${ }^{149}$. É o responsável por que as coisas prossigam sua atividade no mundo e se conservem sem cair no mal ${ }^{150}$.

\footnotetext{
${ }^{141}$ Da teologia mística II.

${ }^{142}$ Da teologia mística III.

${ }^{143}$ Carta 1.

${ }^{144}$ Da hierarquia celeste IV, 1.

${ }^{145}$ Dos nomes divinos I, 3.

${ }^{146}$ Da hierarquia celeste IV, 1.

${ }^{147}$ Dos nomes divinos V, 5.

${ }^{148}$ Dos nomes divinos V, 8.

${ }^{149}$ Dos nomes divinos VIII, 5.

${ }^{150}$ Dos nomes divinos VIII, 9.
} 
Sejam as coisas inanimadas, os seres de vida sensitiva - como as plantas -, os animais irracionais, o homem, dotado de razão, ou os anjos, que têm natureza puramente espiritual, todos são e vivem graças à Causa universal e Fonte de bem ${ }^{151}$. Essa Causa é a medida de todas as coisas ${ }^{152}$. É o motor que tudo conserva. Nela está todo princípio exemplar, final, eficiente, formal e material ${ }^{153}{ }^{154}$

Por isso, afirma o Pseudo Dionísio Areopagita,

devemos atribuir todos os seres a essa Causa e considerá-los unidos em unidade transcendente. É a partir do Ser, por movimento processivo e produtor de essências, como a Causa alcança todas as coisas, dando-lhes plenitude de ser. $^{155}$

A Criação não se deu por mero capricho divino, porém. Ela teve um motivo específico: a bondade superabundante de Deus. Como é próprio da bondade, que nunca se isola egoisticamente, mas sente o desejo amoroso e a necessidade altruísta de compartilhar o bem, Deus - a Bondade supraessencial - não ficou encerrado em si mesmo. Antes, usou seu poder criador para dar a vida e a existência ${ }^{156}$, em que todos os seres se deleitam. Esse Deus é "Princípio e Causa, por sua bondade, de toda vida e essência. Por sua mesma bondade produz e mantém em seu ser todas as coisas". ${ }^{157}$

O Criador permanece separado de suas criaturas. Aquela realidade indizível ultrapassa todo poder, visível e invisível, e é "completamente independente de todas as coisas" ${ }^{, 158}$. Está muito acima de todo $\operatorname{ser}^{159}$. Sendo causa de tudo, está supraessencialmente separado de tudo ${ }^{160}$ e a tudo transcende ${ }^{161}$.

Além de Causa transcendente dos seres, Deus é também a essência desses seres, ou seja, contém em si a essência deles, ainda antes que existam ${ }^{162}$, segundo o Pseudo

\footnotetext{
${ }^{151}$ Dos nomes divinos IV, 2.

${ }^{152}$ Dos nomes divinos II, 10.

${ }^{153}$ Dos nomes divinos IV, 10. racional, os homens.

${ }^{155}$ Dos nomes divinos V, 9.

${ }^{156}$ Dos nomes divinos IV, 10.

${ }^{157}$ Dos nomes divinos I, 3.

${ }^{158}$ Da hierarquia celeste XIII, 4.

${ }^{159}$ Dos nomes divinos I, 1.

${ }^{160}$ Dos nomes divinos I, 5.

${ }^{161}$ Dos nomes divinos I, 7.

${ }^{162}$ Dos nomes divinos I, 4 e 7, IV, 10, VII, 2, VIII, 6.
}

154 Tem-se aqui um exemplo do amplo conhecimento do Pseudo Dionísio Areopagita sobre a cultura grega e do uso que ele faz dela, em favor de suas ideias. A clássica expressão de Protágoras de Abdera, sofista do século V antes de Cristo - "O homem é a medida de todas as coisas" -, é adaptada e passa a se referir a Deus, a verdadeira medida de todas as coisas. O mesmo ocorre com o "primeiro motor" aristotélico e as quatro causas do ser (formal, material, eficiente e final), que o filósofo grego expõe na Metafísica, utilizados agora para designar o Deus cristão. De Aristóteles é também a classificação do mundo físico em seres inanimados, seres com vida vegetativa, seres com vida sensitiva e seres com vida 
Dionísio Areopagita. Todas as coisas se encontram primariamente nele e a partir dele é que passam a existir. Deus é o que dá o ser às coisas inanimadas, às vegetativas, às irracionais, às racionais e às espirituais. Ele é o Ser dos seres ${ }^{163}$.

Como afirma o autor do Corpus dionysiacum:

Deus não é nenhum dos seres. Não. Mas de forma simples e indefinível abarca e contém de antemão em si todo o ser. Por isso se chama Rei dos séculos, pois nele, com Ele e por seu poder todo ser é e subsiste. ${ }^{164}$

Assim, pois, o primeiro atributo da Bondade supraessencial é o dom de ser, e com razão assim se reconhece. Nela e dela mesma é o Ser por si e os princípios das coisas e todas as coisas que são ou venham a ser, de qualquer modo que sejam. ${ }^{165}$

Em Deus estão os "arquétipos" ou "exemplares" das coisas, que são as "razões essenciais" dos seres, aquilo que fundamentalmente os define. Essas razões são determinadas pela vontade divina, que predefine e cria todas as coisas ${ }^{166}$. É também por esse motivo que as Escrituras chamam a divindade de Logos, pois contém em si a causa dos seres, transcendendo-os e penetrando em suas estruturas mais profundas ${ }^{167}$. Na realidade, "Deus é o arquétipo, o único que vive supraessencialmente"168.

Referindo-se ainda a Deus, o Pseudo Dionísio Areopagita afirma:

Em seu poder transcendente, Ele está sobre todas as coisas e na supraessência contém todas as coisas que existem. ${ }^{169}$

Um é seu nome. Isso significa que Deus, por sua unidade supraessencial, é o único onde estão todas as coisas.

E mais:

Nele estão definidas todas as coisas que têm ser e definido o mesmo ser. ${ }^{171}$

O Bem-Formosura, sendo transcendente, acima de todo repouso e movimento, fixa a cada ser sua própria natureza e lhe dá o movimento conveniente. $^{172}$

Tendo Deus como sua causa, as coisas criadas têm participação nele. Esse conceito - participação em Deus - é visto de dois modos principais no Corpus

\footnotetext{
${ }^{163}$ Dos nomes divinos V, 4.

${ }^{164}$ Dos nomes divinos V, 4.

${ }^{165}$ Dos nomes divinos V, 6.

${ }^{166}$ Dos nomes divinos $\mathrm{V}, 8$.

167 Dos nomes divinos VII, 4.

${ }^{168}$ Dos nomes divinos II, 11.

${ }^{169}$ Dos nomes divinos VIII, 6.

${ }^{170}$ Dos nomes divinos XIII, 2.

${ }^{171}$ Dos nomes divinos XIII, 3.

${ }^{172}$ Dos nomes divinos IV, 7.
} 
dionysiacum. $\mathrm{O}$ primeiro deles inclui todas as coisas criadas. $\mathrm{O}$ Universo, as plantas, os animais, o homem, a pedra e a água participam, estão ligados a Deus na medida em que suas essências se encontram nele e receberam dele o ser. Assim como o filho possui algo de seu pai, também as criaturas expressam algo do Criador, pois vieram dele. Daí a visão otimista do mundo cultivada pelo Pseudo Dionísio Areopagita, para quem "em todas as coisas há algo de beleza" ${ }^{173}$, pois procedem daquele que é o máximo bem. "Todas as coisas, pelo mero fato de ser, são boas e procedem do Bem.",174

Deus é a unidade supraessencial, onde se encontram todas as coisas. Por isso é chamado de um. Da mesma forma como todos os números participam da unidade, os seres se reduzem ao princípio único, Deus. "Não pode existir o múltiplo sem participar da unidade", afirma o Pseudo Dionísio Areopagita. "Nada há na natureza das coisas que de alguma maneira não participe na unidade daquele que contém de antemão e em síntese a totalidade universal, incluídas as coisas opostas, que ali se reduzem à unidade.",175

A participação em Deus não se dá diretamente, mas através de dons que procedem dele. Por exemplo, Ele é o Ser e a Vida e concede esses dons às coisas, a fim de que existam e vivam. Os seres que participam desses dons são chamados de "possuidores de essência" e de "viventes". "Por isso, o Bem constitui a base e é o autor dos seres fundamentais." 176

Como afirma o Pseudo Dionísio Areopagita:

Em realidade, nada pode existir sem que dependa de algum modo daquele que é fonte de todo ser. Dele participam as coisas inanimadas pelo mero fato de existir, pois todo ser deve a própria existência à Deidade transcendente. Os viventes, por sua vez, participam do poder que dá a vida e ultrapassa toda vida. Os seres dotados de razão e inteligência participam da Sabedoria, perfeição absoluta, primordial, que ultrapassa toda razão e inteligência. Fica claro, pois, que estes últimos seres estão mais próximos de Deus, porque de muitas maneiras compartilham com Ele. ${ }^{177}$

O segundo modo como o Corpus dionysiacum caracteriza o conceito de participação é mais profundo. Trata-se da obtenção da natureza divina - a “deificação",178 - através da união com Deus. Nesse sentido, participar de Deus é assemelhar-se a Ele. Referindo-se ao hino que, na missa, "celebra tudo quanto Deus fez

${ }^{173}$ Dos nomes divinos II, 3.

${ }^{174}$ Dos nomes divinos IV, 20.

${ }^{175}$ Dos nomes divinos XIII, 2.

${ }^{176}$ Dos nomes divinos XI, 5.

${ }^{177}$ Da hierarquia celeste IV, 1.

${ }^{178}$ A deificação consiste em "fazer-nos semelhantes a Deus e nos unir com Ele o quanto nos é possível" (Da hierarquia eclesiástica I, 3). 
por nós"179, Da hierarquia eclesiástica aponta que esse hino também lembra que Ele "nos fez participantes de suas propriedades divinas, para nos elevar espiritualmente" ${ }^{180}$. O mesmo hino recorda ainda, diz o Pseudo Dionísio Areopagita, que

quando, por nossa loucura, perdemos os dons divinos, Deus se preocupou em restaurar nossa condição primeira oferecendo-nos novos dons. Outorgou-nos a mais perfeita participação de sua natureza divina ao assumir plenamente a nossa. Desse modo, Deus nos concedeu estar em comunicação com Ele e com as realidades divinas. ${ }^{181}$

Quanto mais próximo de Deus ${ }^{182}$, maior a participação em seus dons. Os anjos, seres espirituais, participam mais perfeitamente do divino ${ }^{183}$. Em grau inferior estão os homens. Dotados de alma, estes têm vida espiritual, como os anjos, e podem assim se elevar até o Bem, fazendo-se participantes da sua luz e identificando-se com Ele ${ }^{184}$.

A ideia de que a divinização do indivíduo o transforma num "deus" é descartada. Embora, nesse processo, o homem se torne semelhante a Ele em essência, Deus é o arquétipo, o modelo supraessencial, que não se confunde com suas criaturas, ainda que se encontre nelas. ${ }^{185}$

Além desses dois modos principais de conceituar a participação em Deus, há ainda uma terceira definição no Corpus dionysiacum. É aquela que se refere a participação como finalidade, como desejo, como busca. Segundo o Pseudo Dionísio Areopagita, todos os seres buscam naturalmente o bem e carregam dentro de si o desejo de formosura, o que, na realidade, representa uma busca de Deus, o máximo Bem e Formosura. "Não há nada na natureza que não participe do Bem e da Formosura." 186

Como afirma o Corpus dionysiacum:

Tudo retorna ao Bem como a seu fim. Todas as coisas o desejam: pelo conhecimento, as espirituais e dotadas de razão; pela sensação, as dotadas de sensibilidade, pelo movimento inato do apetite vital, as que não sentem. As que carecem de vida e somente existem propendem a certa participação da essência do um. ${ }^{187}$

\footnotetext{
${ }^{179}$ Da hierarquia eclesiástica III, III, 7. Os críticos acreditam que esse hino citado pelo Pseudo Dionísio Areopagita é o Credo, introduzido na missa em 476, de acordo com opinião de Máximo, o Confessor (T. H. Martin, Obras completas del Pseudo Dionísio Areopagita, p. 216, nota 34).

${ }^{180}$ Da hierarquia eclesiástica III, III, 7.

${ }^{181}$ Da hierarquia eclesiástica III, III, 7.

${ }^{182}$ Lembre-se de que não se trata de proximidade física, como afirma o Pseudo Dionísio Areopagita: "Entendo por proximidade a capacidade maior possível de receber Deus" (Carta VIII, 2).

${ }^{183}$ Da hierarquia celeste VIII, 2.

${ }^{184}$ Dos nomes divinos IV, 2.

${ }^{185}$ Dos nomes divinos II, 11.

${ }^{186}$ Dos nomes divinos IV, 7.

${ }^{187}$ Dos nomes divinos IV, 4.
} 
Embora transcendente, Deus se deixa revelar parcialmente. Isso se dá através das muitas alegorias, figuras, signos e metáforas que, dispersas no mundo sensível e acessíveis ao entendimento, elevam o homem ao conhecimento do divino. Através do símbolo, o divino se transforma em humano, o imaterial se torna material e o indizível é apresentado segundo a maneira de ser dos homens.

Como diz o autor do Corpus dionysiacum:

\begin{abstract}
Não conhecemos Deus por sua natureza, visto que ela é incognoscível e supera toda razão e inteligência. Mas nós o conhecemos pela ordem de todas as coisas, pois estão dispostas por ele mesmo e contêm em si certas imagens e semelhanças de seus exemplares divinos, pelos quais ascendemos ao conhecimento daquele sumo bem e fim de todos os bens, de modo adequado a nossas forças. ${ }^{188}$

Qualquer pessoa, raciocinando, se dá conta de que a formosura aparente é signo de mistérios sublimes. ${ }^{189}$

Todas as coisas podem favorecer a contemplação. ${ }^{190}$
\end{abstract}

Uma das grandes figuras que revelam as coisas divinas é o mundo. Como lembra o Pseudo Dionísio Areopagita, citando o apóstolo Paulo ${ }^{191}$, a reta razão confirma que "todo o mundo visível manifesta os mistérios invisíveis de Deus" $" 192$. Os seres - o céu, o mar, a flor, o homem, a criança, os animais, a pedra - são manifestações do poder e da bondade de Deus. Através do conhecimento das coisas, chega-se - tanto quanto possível - ao conhecimento da Causa dessas coisas, pois elas, inclusive as contrárias entre si, se encontram unidas na mesma origem, assim como as faculdades do corpo se encontram na alma ${ }^{193}$. O que existe no mundo é, de certo modo, um "vestígio" da divina semelhança ${ }^{194}$.

Pode-se recorrer a várias outras metáforas para obter conhecimento das realidades transcendentais. O Corpus dionysiacum cita algumas delas. Em Da hierarquia celeste, o Pseudo Dionísio Areopagita afirma que o fogo, por exemplo, é o símbolo que melhor expressa a maneira como as hierarquias dos anjos transmitem aos homens, espiritualmente, o raio luminoso de Deus. De modo semelhante a esse raio

\footnotetext{
${ }^{188}$ Dos nomes divinos VII, 3.

${ }^{189}$ Da hierarquia celeste I, 3.

${ }^{190}$ Da hierarquia celeste II, 4.

${ }^{191}$ Romanos I, 20: "Desde a criação do mundo, as coisas invisíveis dele (de Deus), como o seu eterno poder e divindade, são observadas pelas obras projetadas"

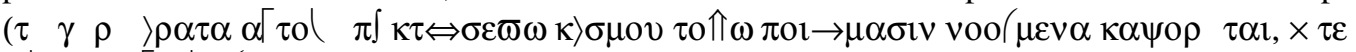

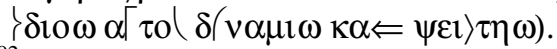

192 Carta IX, 2.

193 Dos nomes divinos V, 7.

${ }^{194}$ Dos nomes divinos IX, 6.
} 
supraessencial, o fogo ilumina todas as coisas sem se manchar ou se confundir com elas. Ninguém pode vê-lo diretamente. Percebido apenas pela matéria onde opera, permanece incognoscível. Renova e transforma tudo quanto alcança, mas é imutável. Penetra em todo lugar, estende-se em todas as direções, sem que ninguém possa detê-lo. De nada necessita. Escondido, parece que não existe, mas aparece de repente, por si só, e se comunica alegremente com seu entorno. ${ }^{195}$

As partes e faculdades do corpo humano também fornecem imagens aplicáveis aos seres celestiais. Os olhos sugerem o poder que os anjos possuem de olhar diretamente as luzes divinas, enquanto o nariz indica a capacidade de sentir plenamente as fragrâncias que o entendimento humano não alcança. E mais:

A faculdade do ouvido significa a capacidade de participar de algum modo na divina inspiração. $O$ gosto faz referência à satisfação do entendimento humano quando bebe até se saciar nos rios da Deidade. O tato significa discernir entre o proveitoso e o nocivo. Sobrancelhas simbolizam o cuidado em guardar o que a mente conhece de Deus. ${ }^{196}$

Ocorre o mesmo na Igreja: as cerimônias e símbolos utilizados na liturgia são expressões sensíveis de realidades inteligíveis ${ }^{197}$. Mesmo os nomes com que Deus é designado servem como metáforas que desvelam características do divino. Quando se diz que Deus é bom, por exemplo, deve-se elevar essa qualidade ao máximo grau possível, e então se sabe que Deus é o sumo bem, a suma bondade. Ao falar que Deus é amor, trata-se do amor máximo, o arquétipo ou modelo de todos os amores. Se se afirma que Ele é vida e paz, está-se falando da verdadeira vida e da verdadeira paz, às quais se subordina tudo o que se pode chamar de vida e de paz, que são só aparência daquelas realidades perfeitas.

Falando do amor, o Pseudo Dionísio Areopagita afirma que Deus "é o verdadeiro amor". Dele derivam os vários desejos amorosos presentes no mundo. Sobre eles tem primazia a Causa de todo desejo amoroso, que todas as coisas se esforçam por alcançar. $^{198}$

Para quem escuta com entendimento a palavra de Deus, o simples termo "amor", tal como o empregam os autores sagrados para manifestar os mistérios divinos, tem o mesmo sentido que "enamoramento". Ambos querem dizer o mesmo: união, aliança, com especial referência ao Bem e Formosura eternos. Procede do Bem-Formosura, graças ao mesmo Bem-

\footnotetext{
${ }^{195}$ Da hierarquia celeste XIII, 2.

${ }^{196}$ Da hierarquia celeste XIII, 3.

${ }^{197}$ Da hierarquia eclesiástica II, III, 2.

${ }^{198}$ Dos nomes divinos IV, 16.
} 
Formosura. Entrelaça as coisas iguais, inclina as superiores a cuidar das inferiores e faz que estas tendam às mais altas. ${ }^{199}$

Assim, aquela realidade indizível chamada Deus, ainda que se encontre completamente fora do alcance da reflexão e até da imaginação do homem, está bem presente no mundo sensível e impregna as coisas criadas, entre elas, os seres humanos. Embora seja mais fácil designá-la pelo que não é do que pelo que é, faz-se revelar parcialmente através de imagens e metáforas - como o mundo, cuja beleza reflete o Belo perfeito - e constitui a principal aspiração dos seres, ainda que estes não se dêem conta disso.

${ }^{199}$ Dos nomes divinos IV, 12. 
PARTE II: TOMÁS DE AQUINO 


\section{TOMÁS LEITOR DE DIONÍSIO}

O filósofo alemão Josef Pieper $^{200}$ faz, a respeito da recepção de Aristóteles por Tomás de Aquino, afirmações que são válidas também para a forma como o Aquinate leu as obras do Pseudo Dionísio Areopagita. Segundo Pieper, ao contrário do que sugerem os manuais tomistas - que persistem em classificar o mais original pensador medieval com a desgastada e equivocada fórmula "o fundador do aristotelismo cristão da Idade Média" -, Tomás não aceita as ideias aristotélicas passivamente, como se elas fossem verdadeiras exclusivamente porque foram ditas pelo mestre grego.

Bem diferente disso, Tomás busca em Aristóteles e em qualquer outro pensador aquilo que possa contribuir para esclarecer um dado assunto. Muitas vezes, diz Pieper, o Aquinate defende Platão contra Aristóteles. Conceitos tipicamente platônicos, como o de participação, marcam profundamente o pensamento tomasiano.

Para Pieper, a expressão sempre repetida por Tomás - "como disse o Filósofo" (“sicut patet per Philosophum") - não significa dizer que algo é verdadeiro porque Aristóteles o disse, mas sim que o filósofo mostrou que é evidente, e por isso é válido. É válido porque é verdadeiro. "Quem cita dessa maneira não cita, em sentido estrito, uma autoridade. Não se liga ao autor”, acrescenta Pieper. “Tomás nunca supôs que a doutrina de Aristóteles fosse sempre de acordo com a doutrina cristã, ainda que certamente houvesse tais opiniões entre os aristotélicos medievais."

O que importa para Tomás é encontrar "a verdade das coisas", seja lá qual for o pensador que consiga trazê-la à luz. É o que ele afirma, por exemplo, num de seus comentários a Aristóteles:

O estudo da filosofia não é para saber o que disseram os homens, mas sim a verdade das coisas. $^{202}$

Para Tomás, o argumento de autoridade é o mais débil dos argumentos, uma vez que se apoia sobre o limitado entendimento humano, enquanto aquele que se fundamenta na revelação divina é o mais forte, como ele diz na Suma teológica ${ }^{203}$. "Os

\footnotetext{
200 Josef Pieper, Filosofia medieval y mundo moderno. Madrid: Ediciones Rialp, 1973.

${ }^{201}$ Josef Pieper, obra citada, p. 262-263.

202 In libros De caelo et mundo, lib. 1 1. 22 n. 8.

${ }^{203}$ Suma teológica I, q. 1, a. 8.
} 
argumentos filosóficos são válidos não por causa da autoridade daqueles que os dizem, mas por causa do que é dito.”204

Assim, Aristóteles não é o mestre incontestável de Tomás, e este não aceita acriticamente as ideias daquele. Porém, é preciso reconhecer que uma característica originária do aristotelismo marca indelevelmente a teologia e a filosofia do Aquinate: trata-se da recusa em se distanciar do real concreto, em se deixar afastar do que está diante dos olhos ${ }^{205}$. É precisamente essa atitude fundamental que é aceita por Tomás com toda a veemência. É a decidida aproximação ao concreto, à realidade experimentável do mundo. As coisas concretas que se podem ver, ouvir, experimentar, cheirar e tocar são tomadas como algo propriamente real, como realidade por direito próprio, não como mero reflexo ou sombra, não como mero símbolo de outra cousa invisível, do que está além, não como algo espiritual - diz o filósofo alemão.

O visível e também o ver, o conhecimento sensível e a faculdade desse conhecimento, tudo isso é afirmado e reconhecido como algo válido em si mesmo, e isso quer dizer: o mundo corpóreo da realidade material, também no próprio homem - o corpo, os sentidos e o que eles chegam a perceber, tudo isso se toma a sério de uma forma inaudita até então. ${ }^{206}$

Como foi dito, o que Pieper fala a respeito de Aristóteles vale também para a assimilação do Pseudo Dionísio Areopagita por Tomás de Aquino. Da mesma forma como acontece com o Estagirita, o Aquinate não aceita passivamente as ideias do autor de Da teologia mística. Antes, dá-se uma criativa e original leitura da obra dionisiana, sempre com o objetivo de descobrir nela a veritas rerum, a verdade das coisas.

Assim como Aristóteles é responsável pela atitude fundamental de aceitação da realidade concreta, assumida por Tomás, Dionísio é também responsável por uma postura fundamental do Aquinate, que marca profundamente sua teologia e filosofia. Referimo-nos ao elemento negativo do pensamento tomasiano - a ideia de que a existência está envolta em mistério e que o intelecto humano é incapaz de compreender a essência mais profunda das coisas, muito menos a Causa primeira de tudo. Essa atitude de negatividade, o Aquinate deve-a inegavelmente ao Pseudo-Dionísio Areopagita, como será mostrado no próximo capítulo.

Assim, percebe-se claramente qual foi a principal contribuição de cada um dos três pensadores de maior influência sobre Tomás: Aristóteles, Santo Agostinho e o Pseudo Dionísio Areopagita. De Aristóteles e de Dionísio, como foi mostrado, o

\footnotetext{
${ }^{204}$ In Trin. 2, 3, ad 8.

${ }^{205}$ Josef Pieper, obra citada, p. 255.

${ }^{206}$ Josef Pieper, obra citada, p. 255-256.
} 
Aquinate herdou a valorização do concreto e a negatividade. Já de Santo Agostinho, pode-se dizer, ele tomou a espiritualidade, a sincera aceitação do Evangelho, que o levou, jovem ainda, a entrar na ordem dos dominicanos.

A atitude de apego ao concreto, à realidade visível - marca aristotélica do pensamento tomasiano - moldará a leitura que Tomás faz do Pseudo Dionísio Areopagita. Explique-se. Como foi analisado nos capítulos anteriores, a teologia dionisiana aponta para a radical transcendência do divino. Este é tão transcendente, está tão distante do entendimento humano que se encontra acima até mesmo acima do ser. Deus não é ser, mas o criador dos seres, e por isso não pode ser confundido com nenhum deles.

Tomás aceita essa transcendência Deus, mas com uma importante diferença. Para ele, Deus é o Ser transcendente que dá o ser, que transfere ser às criaturas para que elas sejam. É o Ser dos seres. Ou seja, fiel à atitude aristotélica de valorização do real, Tomás como que faz "baixar à terra" a teologia radicalmente espiritualista do Pseudo Dionísio Areopagita. Da mesma forma como se diz que Aristóteles trouxe para o terreno do real a filosofia de Platão, vendo na essência das coisas concretas a "forma" das Ideias eternas platônicas, Tomás também tornou mais concreto o pensamento de Dionísio, apontando nos seres do cotidiano um reflexo - infinitamente precário e deficiente - do Ser superior ao máximo grau. Com isso, evitou a transcendência radical do Deus dionisiano, que poderia se confundir com uma concepção agnóstica do divino, tão desconhecido e inalcançável que se confunde com o não-ser.

Alguns autores notaram essa diferença entre as concepções dionisianas e tomasianas do divino. Bogdan G. Bucur ${ }^{207}$, por exemplo, cita esta passagem de Tomás:

"Deve-se dizer que Deus não é um existente, como se de nenhum modo fosse
existente, mas que está acima de todo e qualquer existente, pois Ele é seu ser.
Portanto, daí não se segue que não possa ser conhecido de maneira nenhuma,
mas que excede todo conhecimento, isto é, que não pode ser
compreendido.

Bucur comenta que esse trecho da Suma teológica contém duas ideias de extrema importância. A primeira delas se refere ao fato de que Tomás opera uma mudança fundamental no status do ser em relação a Deus. Enquanto Dionísio coloca Deus além do ser, postulando-o como radicalmente diferente - apesar de causa do ser -,

\footnotetext{
${ }^{207}$ Bogdan G. Bucur, "The theological reception of Dionysian apophatism in the Christian East and West: Thomas Aquinas and Gregory Palamas", p. 135-136 (www.bgbucur.com/PDFuri/DionysiusApophatismDownsideReview.pdf).

${ }^{208}$ Suma teológica I, q. 12, a. 1, ad 3.
} 
para o Aquinate "Deus é o superesse porque ele é ser superlativamente: o Esse puro e simples", escreve Bucur, citando Ettienne Gilson.

A outra ideia que sobressai do texto extraído da Suma teológica, continua Bucur, diz respeito à epistemologia. Tendo em vista que Deus é o superesse, o nosso conhecimento das coisas não é meramente um conhecimento de alguma coisa que Deus não é. Podemos dizer que Ele é preeeminente a todas as coisas, que o ser das coisas pertence a Ele antes de pertencer às criaturas. É a maneira de ser de Deus que nos escapa. As coisas invisíveis de Deus continuam a transcender nosso conhecimento, mas elas transcendem na própria linha do ser. A diferença entre Deus e as criaturas é como uma diferença entre duas ordens de coisas. Há uma continuidade metafísica e epistemológica entre Deus e os seres que está fundamentada na analogia do ser e se estende à essência. "Estamos claramente num sistema diferente do original

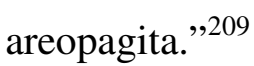

Rudi A. te $\operatorname{Velde}^{210}$ fala de uma "pequena mas significativa" mudança do pensamento dionisiano trazida pela interpretação de Tomás de Aquino. Segundo Velde, para Dionísio Deus é o "ser em si", a causa de todos os seres, mas é também chamado de "causa do ser em si", na medida em que se encontra acima de todos os seres, até mesmo acima do ser em si, ou seja, no oculto centro da deidade. Em contraste, compara Velde, para Tomás, o termo "ser em si" se aplica a Deus não como causaliter, como causa de todos os seres, mas como substantialiter, nome que designa a transcendência de Deus acima de todas as coisas. E quando Dionísio cita Deus como a "causa do ser em si", Tomás dá a essa expressão o significado de "causa do ipsum esse commune", o ser que é comum a todas as coisas.

Para Tomás, é preciso fazer uma distinção entre o ipsum esse que é Deus e o ipsum esse que procede de Deus nas criaturas. O primeiro é algo subsistente, distinto por si mesmo das outras coisas, e o segundo é comum a todos os seres, acrescenta Velde. Em contraste com Dionísio, cuja aproximação com a transcendência divina permanece negativa, Tomás afirma a positiva identidade em Deus do Ser em si, da Vida em si e da Inteligência em si. "Para Tomás, de Deus não se diz propriamente que está 'acima' do ser, a menos que se restrinja o significado de 'ser' ao ser finito das criaturas. Deus é a infinita plenitude do ser."211

\footnotetext{
${ }^{209}$ Bogdan G. Bucur, obra citada.

${ }^{210}$ Rudi A. te Velde, Participation and substantiality in Thomas Aquinas. Leiden: Brill, 1995.

${ }^{211}$ Rudi A. te Velde, obra citada, p. 265.
} 
Fran O’Rourke ${ }^{212}$ faz uma precisa comparação entre a metafísica de Dionísio e a de Tomás de Aquino. Segundo ele, Dionísio, de acordo com a tradição platônica, afirma o primado do Bem. Deus é o Bem absoluto, ultrapassando o Ser em dignidade e poder, e, como infinita perfeição e amor o Bem é a fonte de difusão da criação. Diferente de seus predecessores, porém, Dionísio reduz todas as perfeições da realidade finita à penetrante presença e poder do bem, eminente e imanente, que é o primeiro efeito da ação criadora de Deus. A unidade da causalidade faz do Bem a primeira perfeição criada, e restaura a universal e absoluta transcendência de Deus como única causa criadora. O Ser, de acordo com Dionísio, é portanto a perfeição primária da realidade finita, sua primeira e imediata participação no absoluto.

Tomás - aponta O’Rourke - adota inteiramente a prioridade do Ser na realidade finita, mas, aprofundando a noção de ser como perfeição, estabelece seu caráter transcendental de modo a aplicá-la a Deus num sentido preeminente. Para Tomás, portanto, o Ser não é simplesmente a primeira participação da realidade finita em um Bem transcendente, mas é a própria perfeição ilimitada - a essência mesmo de Deus e, desse modo, seu próprio nome. Bondade é um aspecto co-extensivo do Ser, idêntico a ele na realidade, mas teoricamente secundário em significação. Portanto, continua O’Rourke, pode-se dizer que Tomás faz sua a noção dionisiana do Ser, mas a aprofunda à luz da noção de bondade de Dionísio, adotando o primado do Bem afirmado por Dionísio, ao mesmo tempo em que restaura o significado implícito do Ser, que numa reflexão mais profunda, é visto como primário. O’Rourke completa:

Estabelecendo o primado do Ser num sentido absoluto, Tomás de Aquino,
por sua vez, dedica a ele a excelência do Bem neoplatônico, atribuindo ao Ser
a difusão geradora da perfeição. Ele une, portanto, no interior de uma mais
profunda teoria do Ser, a visão de Dionísio do primado da existência no
domínio do finito e o caráter transcendente do Bem. Assim, a transformação
efetuada por Tomás pode até ser vista como uma mais profunda e persistente
aplicação de um insight sobre o radical caráter do Ser, que Dionísio tinha
restringido à realidade finita.

A diferença fundamental entre Dionísio e Tomás - o predomínio da abstração e da transcendência no primeiro, a ênfase dada ao real concreto, no segundo -, verificada no que se refere à discussão sobre o ser, está presente também num dos mais fascinantes temas abordados pelos dois pensadores: a questão do mal.

\footnotetext{
${ }^{212}$ Fran O'Rourke, Pseudo-Dionysius and the metaphysics of Aquinas. Notre Dame: University of Notre Dame Press, 2005.

${ }^{213}$ Fran O'Rourke, obra citada, p. 276.
} 
Como foi citado antes ${ }^{214}$, para Dionísio, o mal não tem essência nem existência própria, pois tudo o que existe é criação de Deus, o suprabem, o Bem máximo, que não pode dar origem ao mal - o que seria uma contradição, já que o bem não cria o mal. Porém, esse Bem está presente nas coisas de acordo com certa gradação: está mais num ser e menos em outro. Tudo o que existe é mais ou menos ser, tem mais ou menos bem, conforme está mais perto ou mais distante da fonte do bem, que é Deus. Sem essência nem existência, o mal tem como fundamento o bem, pois mesmo quando se pratica o mal é o bem a que se visa. O ladrão, por exemplo, não vê o mal ao roubar e assassinar outra pessoa, e sim busca o bem que o valor roubado the proporcionará. O mal, portanto, não existe, não tem materialidade. Ele se dá na ausência do bem.'

A natureza não contém o mal, que consiste na incapacidade de alcançar o mais alto grau de perfeição a que as coisas criadas estão chamadas ${ }^{215}$. Como já foi apontado, se algo está completamente distante do Bem, esse algo não existe, pois sem o Bem não há essência nem vida. Até os demônios têm algo de bem, uma vez que existem. Se não tivessem pelo menos uma centelha da bondade divina, não teriam ser e, portanto, não existiriam. Tudo o que existe é mais ou menos ser na medida em que participa do Bem. Isso vale para a matéria e o espírito, para o corpo e a alma.

Basicamente, é isso o que afirma o Pseudo-Dionísio Areopagita a respeito do mal no mundo. Percebe-se nitidamente, nesse discurso, a principal característica da teologia dionisiana: um pensamento voltado para o abstrato, para as dimensões infinitas da transcendência. Passemos agora a analisar o que Tomás de Aquino afirma sobre o mesmo tema - e logo perceberemos o contraste entre os dois pensadores. Ou melhor, notaremos como Tomás se utiliza das ideias de Dionísio, assimilando-as de forma criativa e dotando-as de um caráter mais concreto.

Já no início da Questão disputada sobre o mal, Tomás demonstra sua tendência a se voltar para o concreto. Ele afirma que há dois modos de se referir ao mal. Num modo, fala-se do mal em si, e nesse sentido não é algo, e sim privação de algum bem particular. Noutro modo, o mal pode ser entendido como o que é sujeito do mal, e nesse sentido é algo. Por exemplo, o ser cego não é algo, mas o que acontece com o cego é algo. Ou seja, embora o mal não seja algo em si, ele se manifesta no sujeito concreto do mundo real, assim como o branco não é nada por si mesmo, mas está presente no que é sujeito da brancura.

\footnotetext{
${ }^{214}$ Cf. capítulo 1, "O filósofo do não-saber".

${ }^{215}$ Dos nomes divinos IV, 26.
} 
Uma das razões que Tomás dá para mostrar que é impossível o mal ser algo é o fato de que tudo o que há nas coisas possui alguma inclinação e o desejo natural daquilo que lhe convém. Ora, diz o Aquinate, tudo o que tem razão de apetecível tem caráter de bem. Logo, tudo o que há nas coisas se encontra de acordo com algum bem. O mal, porém, enquanto tal, não está de acordo com o bem, mas se opõe a ele. Logo, o mal não é algo nas coisas. "Mas, se o mal fosse alguma coisa, não apeteceria nem seria apetecido por algum outro; e, por conseguinte, não teria nenhuma ação nem movimento, posto que nada atua nem se move a não ser por causa do apetite do fim." ${ }^{216}$

Outra das razões da não existência do mal, segundo Tomás, é manifestada pelo fato de que o ser mesmo tem caráter de apetecível, uma vez que cada coisa apetece naturalmente conservar seu ser: por um lado, afasta-se das coisas destrutivas do seu ser e, de outro, resiste a elas na medida de suas possibilidades. Assim, o ser mesmo, na medida em que é apetecível, é bom. Logo, é necessário que o mal, que universalmente se opõe ao bem, se oponha ao que é ser. Mas o que é oposto ao que é ser não pode ser algo, diz Tomás, que afirma ainda, numa das respostas às objeções da Questão:

\begin{abstract}
Cada coisa possui mais mal do que outra não por acercar-se a algo sumamente mal nem por sua diversa participação de alguma forma, como se diz que algo é mais ou menos branco, segundo sua diversa participação da brancura; mas se diz eu algo é mais ou menos mal segundo seja mais ou menos privado de um bem, não certamente de um modo efetivo, e sim de um modo formal. Com efeito, o homicídio se diz maior pecado que o adultério não porque corrompa mais o bem natural da alma, e sim porque remove mais a bondade do ato mesmo: efetivamente, é mais contrário ao bem da caridade pelo que deve ser informado um ato virtuoso o homicídio do que o adultério. ${ }^{217}$
\end{abstract}

O mal se dá, diz Tomás, quando ocorre uma perversão ou uma debilidade do bem. O bem que é uma perfeição está privado de mal, e nele, portanto, não pode existir o mal. Entretanto, o bem que está composto de sujeito e perfeição pode ser debilitado pelo mal e, quando a perfeição é eliminada, permanece o sujeito, assim como a cegueira priva a capacidade de ver, debilita o olho que vê e existe na substância do olho. "De onde, se existe algum bem que é ato puro, sem mescla de nenhuma potência, do modo como é Deus, em tal bem de nenhum modo pode existir o mal."218

No seu Comentário aos nomes divinos de Dionísio, Tomás se expressa assim:

Analogamente, não se pode afirmar que o mal seja a causa eficiente de qualquer coisa. De fato, o que pertence à essência do bem não pode pertencer ao mal. Mas produzir e salvar pertencem naturalmente ao bem e são da sua

\footnotetext{
${ }^{216}$ Questão disputada sobre o mal, q. 1, a. 1.

${ }^{217}$ Questão disputada sobre o mal, q. 1 a. 1 ad 13.

${ }^{218}$ Questão disputada sobre o mal, q. 1, a. 2
} 
essência, porque a geração e a salvação são obras boas, enquanto destruir e arruinar pertencem à essência do mal. Do que deriva a consequência de que somente o bem é causa dos seres existentes e que o mal não é causa de nenhum ser existente. E ainda que, se o mal não vem do bem como sua própria causa, ele não tem uma causa e não é causado. ${ }^{219}$

Mas há ainda um outro tema - tão ou mais fascinante do que a questão do mal em que Tomás “corrige" Dionísio. Muitas vezes ao longo dos séculos, o autor de Dos nomes divinos foi acusado de defender um imanentismo tipicamente neoplatônico, em lugar do relato bíblico da Criação divina. Essa crítica foi é assim exposta por Guido de Ruggiero:

\begin{abstract}
A inspiração mística desse imanentismo, o caráter natural, físico, no qual é concebida a ação divina, dão à doutrina do Areopagita uma entonação panteísta, que ofusca um dos maiores princípios da especulação cristã: o da personalidade. O Deus dessa filosofia não se pode mais chamar uma pessoa, um sujeito absoluto, uma causa livre. Uma necessidade natural e fatal domina a sua ação e faz do ciclo dialético da sua proodos e da sua epístrofe quase um fluxo e refluxo de um agente natural. Sente-se a mais estreita dependência do Areopagita da fonte neoplatônica, e não da cristã, apesar de a veste exterior da doutrina cristã ser cuidadosa e habilmente preservada. ${ }^{220}$
\end{abstract}

Em outras palavras, na filosofia do Pseudo-Dionísio Areopagita, na visão de Ruggiero, poderia ser identificado, à maneira da filosofia neoplatônica, um Deus que cria graças a um impulso natural, uma necessidade irrefreável, como característica do seu ser, Bondade suprema, que precisa difundir sua bondade transbordante para todas as coisas da natureza. Deus seria, assim, como o sol - uma comparação freqüente na obra de Dionísio -, que ilumina todas as coisas por necessidade de sua natureza.

No Comentário aos nomes divinos, Tomás corrige essa ideia. Ali ele afirma:

\begin{abstract}
O ser do sol não é o seu conhecer nem o seu querer, ainda que suponhamos que seja dotado de inteligência e de vontade, e por isso tudo o que faz com seu ser não faz com o intelecto e com a vontade. Mas o ser divino é o seu conhecer e o seu querer e isso que ele faz com o seu ser faz com o seu intelecto e com sua vontade. ${ }^{221}$
\end{abstract}

Deus é a causa de toda vida e todo ser, não por um processo de emanação necessária, comenta O’Rourke ${ }^{222}$, lembrando que, para Tomás, a vontade divina transcende as categorias de necessidade e contingência, "natural" e "não natural". Como causa Ele se situa fora da ordem dos seres e produz todo ser e todas as suas diferenças, incluindo a possibilidade e a necessidade. A origem da necessidade e da contingência é

${ }^{219}$ Comentário aos nomes divinos IV, 14, 24.

${ }^{220}$ Guido de Ruggiero, La filosofia del cristianesimo, Roma: Laterza, 1967, vol. 1, p. 365.

${ }^{221}$ Comentário aos nomes divinos IV, 1, 11.

${ }^{222}$ Fran O'Rourke, Pseudo-Dionysius and the methaphysics of Aquinas. Notre Dame: University of Notre Dame Press, 2005. 
a vontade divina, que, como causa primária transcende a ordem da necessidade e da contingência. "Como Ser subsistente, não há nada que venha a constranger Deus. Uma vez que ele é perfeitamente simples, não existe nele nenhuma distinção que pudesse ocasionar oposição inerente ou interna. Até a distinção 'natural' e 'não natural' é inapropriada." 223

Bastam os exemplos citados para dar uma ideia da assimilação criativa e original - e não passiva e subserviente - de Dionísio por Tomás.

Uma assimilação que foi notada por Ignácio Andereggen ${ }^{224}$, num estudo sobre o Comentário aos nomes divinos de Tomás, que vale perfeitamente para descrever toda a postura do Aquinate frente ao legado dionisiano. Segundo Andereggen,

O resultado global do nosso estudo conduz a constatar a fidelidade profunda de Santo Tomás às intuições mais importantes de Dionísio. Mas uma fidelidade atenta e inteligente, que permite pôr em relevo a grandeza de cada um dos dois pensadores: o véu místico e profundo do Areopagita e sua suposição por parte do Aquinate na inteligência estrita da realidade. A posição de ambos se completa, se ilumina e se compenetra. ${ }^{225}$

O conceito de negatividade e a ideia de participação - esta intimamente relacionada ao elemento negativo do pensamento tomasiano - são ótimos exemplos da forma "atenta e inteligente" como Tomás trata as intuições de Dionísio, para usar as palavras de Andereggen. É o que se verá com mais detalhes nos capítulos a seguir.

\footnotetext{
${ }^{223}$ Fran O'Rourke, obra citada, p. 254.

${ }^{224}$ Ignacio Andereggen, "La originalidad del comentário de Santo Tomás al De divinis nominibus de Dionísio Areopagita", in Denys l'Aréopagite et sa posterité em Orient et en Occident - Actes du Colloque International, Paris 21-24 septembre 1994, editado por Ysabel de Andia. Paris: Institut d'Études Augustiniennes, 1997, p. 439-455.

${ }^{225}$ Ignacio Andereggen, obra citada, p. 451.
} 


\section{O PENSAMENTO NEGATIVO DE TOMÁS DE AQUINO}

O pensamento de Tomás de Aquino sempre exerceu profunda influência em diferentes áreas do conhecimento - como a teologia, a filosofia e a educação -, desde quando foi concebido, no século XIII, até hoje, em pleno século XXI. Entretanto, essa influência se deu sem que fosse considerado o elemento negativo da obra tomasiana, que permaneceu praticamente ignorado ao longo do tempo. Trata-se de um equívoco monumental, pois esse elemento - cuja fonte é o Pseudo Dionísio Areopagita - afeta profundamente toda a estrutura do pensamento do Aquinate. Sem considerá-lo, altera-se de tal forma a sua obra que já não se pode mais falar propriamente em "teologia ou filosofia de Tomás de Aquino", mas sim, talvez, apenas em ideias sob inspiração de Tomás de Aquino - ou “tomismo", como é mais comum.

Um dos poucos pensadores que perceberam a importância fundamental do elemento negativo na obra tomasiana foi o alemão Josef Pieper (1904-1997). Ele explica o que é a negatividade em Tomás de Aquino num ensaio publicado em Unaustrinkbares Licht, já traduzido no Brasil ${ }^{226}$. Segundo Pieper, as doutrinas tomasianas do ser e da verdade - e, de resto, todo o pensamento do Aquinate - só podem ser devidamente compreendidas caso se leve em conta o decisivo papel que tem, na filosofia de Tomás, o conceito de Criação - ou seja, a ideia de que todas as coisas são creaturas. Esse conceito, por sua vez, está intimamente relacionado com o elemento negativo de incognoscibilidade e de mistério.

Para Tomás - explica Pieper -, o ser e a verdade estão indissoluvelmente ligados. As coisas são verdadeiras porque são pensadas por Deus. Elas possuem um "quê", uma quididade, um determinado conteúdo essencial porque são fruto de um pensamento projetador e criador. A diferença entre essa ideia e a afirmação de que só se pode chamar de verdadeiro o que é pensado - repetida pelos pensadores modernos, de Bacon a Kant - é que, para Tomás, as coisas reais são, de fato, algo pensado, pensado criadoramente pelo Logos.

\footnotetext{
${ }^{226}$ Josef Pieper, "O elemento negativo na filosofia de Tomás de Aquino - a propósito de uma sentença de Avicena”, tradução de Gabriele Greggersen Bretzke, Revista de Estudos Árabes, Centro de Estudos Árabes da Faculdade de Filosofia, Letras e Ciências Humanas da Universidade de São Paulo, número 5/6, janeiro/dezembro de 1995, p. 53-75.
} 
Isso é confirmado até mesmo pelo moderno existencialismo, aponta Pieper. Em sua radical tentativa de "extrair todas as consequências de uma posição ateia coerente", como afirma em L'existentialisme est un humanisme, o filósofo francês Jean-Paul Sartre (1905-1980) disse que "não há essência do homem, porque não há Deus para concebêla" ${ }^{227}$. Em outras palavras, é o mesmo que dizer: "As coisas têm uma essência porque são pensadas. Os objetos fabricados pelo homem têm uma essência porque foram concebidos por uma mente criadora. Como não há Deus para pensar o homem, este não tem uma essência". Embora negue a Criação, Sartre raciocina sobre a mesma base, sobre a mesma ideia de que a essência de um ser depende de uma inteligência criadora, que dê a ele um conteúdo de significado através do pensamento criador - ideia que, para Pieper, representa o fundamento da clássica metafísica ocidental do ser.

Segundo Tomás, a realidade natural está situada entre dois cognoscentes, o intelecto divino - o conhecimento criador de Deus, que pensa o ser - e o intelecto humano, que se dirige ao $\operatorname{ser}^{228}$. Ela é, portanto, uma estrutura articulada entre "Projetador" e "apreensão do projeto, realizado no ente". "De acordo com essa dupla referência das coisas é que Tomás desenvolve sua doutrina. Há, assim, um dúplice conceito de 'verdade das coisas': o primeiro afirma o ser-pensado por Deus; o segundo, a inteligibilidade para o espírito humano." 229 Dessa forma, acrescenta Pieper, afirmar que "as coisas são verdadeiras" significa dizer que as coisas são pensadas por Deus e que as coisas são acessíveis ao conhecimento humano.

Porém, embora o fato de serem pensadas fundamente a inteligibilidade das coisas para o homem, esse mesmo fato determina também a impossibilidade de o ser humano compreender cabalmente a essência das coisas. Acontece que, para Tomás, pode-se falar de "verdade das coisas" de duas maneiras: uma delas consiste na correspondência entre o intelecto humano e as criaturas; a outra se refere à correspondência entre a criatura e o pensamento criador que a projetou.

Entre essas duas correspondências existe uma diferença fundamental: a primeira (pensamento humano para com a realidade) pode tornar-se objeto de conhecimento do homem, enquanto a segunda (realidade para com o Pensamento) não pode ${ }^{230}$. Em outros termos, o homem tem a potência de conhecimento das coisas, mas não lhe é possível

\footnotetext{
227 "Il n'y a pas de nature humaine, puisqu'il n'y a pas de Dieu pour la concevoir" (Jean-Paul Sartre, Le existentialisme est un humanisme, Paris, 1946, p. 22). Citado por J. Pieper, obra citada, p. 60.

${ }_{228}^{28}$ Quaestiones disputatae de veritate I, 2.

${ }^{229}$ J. Pieper, obra citada, p. 61-62.

${ }^{230}$ J. Pieper, obra citada, p. 64.
} 
conhecer formalmente a sua verdade. $\mathrm{O}$ ser humano conhece a imagem imitativa dos seres, mas não a sua correspondência com o arquétipo, a relação existente entre o serpensado e o seu projeto. Como explica Pieper:

A relação de correspondência existente entre a imagem arquetípica em Deus e a imagem criada que a segue - e nisso consiste formal e primariamente a verdade das coisas - não poderá jamais, como dizíamos, ser diretamente apreendida pelo nosso olho; não podemos alcançar um ponto de vista a partir do qual nos seja possível comparar a imagem arquetípica com a sua imagem imitativa; somos simplesmente incapazes de assistir, por assim dizer, como espectadores à emanação das coisas "do olho de Deus". 231

A ideia de que Deus está muito acima do entendimento humano é clara na obra de Tomás de Aquino. Tomem-se, por exemplo, as seguintes frases, que aparecem no início da Suma teológica:

Mas como de Deus não podemos saber o que é, mas o que não é, não podemos considerar de Deus como é, mas podemos como não é. ${ }^{232}$

Não podemos conhecer o ser de Deus nem sua essência. ${ }^{233}$

Claramente, a fonte desse pensamento tomasiano é o Pseudo Dionísio Areopagita, que fala de Deus nos mesmos termos. Observando a inadequação de se referir ao divino tanto com nomes mais "nobres" - como Verbo, Inteligência, Vida e Luz - como com expressões que designam meros seres criados - como Rocha -, o autor de Dos nomes divinos destaca que a melhor maneira de se referir a Deus é através da negação:

Ocorre, por isso, que as mesmas Escrituras louvam a Deidade com expressões totalmente dessemelhantes. Chamam-na invisível, infinita, incompreensível e outras coisas que dão a entender não o que é, mas o que não é. Esta segunda maneira, a meu entender, é muito mais própria falando de Deus, pois, como a secreta e sagrada tradição nos ensina, nada de quanto existe se parece com Deus e desconhecemos sua supraessência invisível, inefável, incompreensível. ${ }^{234}$

Não compreendemos quanto se refere à natureza sobrenatural de Jesus. ${ }^{235}$

Nelas (nas Escrituras), Deus mesmo se dignou nos ensinar que nenhuma criatura pode chegar a conhecê-lo e a contemplá-lo tal como é, já que Ele transcende tudo supraessencialmente. ${ }^{236}$

\footnotetext{
${ }^{231}$ J. Pieper, obra citada, p. 68-69.

${ }^{232}$ Suma teológica I, 3, prólogo.

${ }^{233}$ Suma teológica I, 4.

${ }^{234}$ Da hierarquia celeste II.

${ }^{235}$ Dos nomes divinos II.

${ }^{236}$ Dos nomes divinos I.
} 
No Comentário ao De Trinitate de Boécio ${ }^{237}$, Tomás afirma que há três graus do conhecimento humano a respeito de Deus: o mais fraco deles é o que reconhece Deus através das obras da Criação; o segundo é o que o reconhece refletido nos seres espirituais; e o terceiro, o grau superior, reconhece Deus como o Desconhecido. O Aquinate também diz:

Este é o máximo grau de conhecimento humano de Deus: saber que não o conhecemos. $^{238}$

Essa ideia tomasiana se aproxima muito do pensamento do Pseudo Dionísio Areopagita, que afirma:

Mas a maneira mais digna de conhecer a Deus se alcança não sabendo, pela união que ultrapassa todo entender. Quando a inteligência, afastando-se de todas as coisas e esquecendo-se inclusive de si mesma, se une aos raios que brilham do alto, fica iluminada naquele imperceptível abismo da Sabedoria. $^{239}$

Ele ultrapassa todo ser e conhecer. Seu Ser está mais além de todo ser. A mente não alcança conhecê-lo. Negando-lhe, pois, existência como a nossa, negando que nosso conhecimento o conhece, esse perfeito não-saber é o melhor sentido, é conhecer aquele que está mais além de quanto se pode conhecer. $^{240}$

Na Suma contra os gentios, Tomás lembra que existem verdades a respeito de Deus que ultrapassam totalmente as capacidades da razão humana. Para ele, o conhecimento intelectual tem seu ponto de partida nos sentidos corporais, de modo que tudo o que não cai sob o domínio dos sentidos não pode ser apreendido pela inteligência humana. Embora os objetos sensíveis conduzam a um certo conhecimento de Deus, pois são criação dele, não podem permitir o acesso à substância ou essência divina, pois há uma diferença de nível entre a causa e o efeito. "Por conseguinte, existem em Deus verdades inteligíveis, as quais são acessíveis à razão humana: em contrapartida, há outras que superam totalmente as forças da razão humana."241 Como diz Tomás, "a inteligência humana é incapaz, pelas suas próprias forças, de apreender a substância ou a essência íntima de Deus" ${ }^{242}$.

O Pseudo Dionísio Areopagita diz a mesma coisa em vários trechos da sua obra:

\footnotetext{
${ }^{237} \mathrm{I}, 2$ ad 1.

${ }^{238}$ Quaestiones disputatas de potentia Dei q. 7, a. 5 ad 14.

${ }^{239}$ Dos nomes divinos VII.

${ }^{240}$ Carta I. Nessa mesma carta, o Pseudo Dionísio Areopagita afirma que considera o não-saber não como uma privação, mas como transcendência.

${ }^{241}$ Suma contra os gentios III.

${ }^{242}$ Suma contra os gentios III.
} 
Qualquer palavra ou conceito resultam inadequados para expressar o desconhecido da supraessência, que está muito acima de todo ser. Necessitamos, para isso, de um conhecimento supraessencial. ${ }^{243}$

O corpóreo não aprisiona o intangível e incorpóreo. Do mesmo modo, e com toda verdade, aquela infinita supraessência transcende toda essência; aquela Unidade está mais além de toda inteligência. Nenhum raciocínio pode alcançar aquele Uno inescrutável. Não há palavras com que se possa expressar aquele Bem inefável, o Uno, fonte de toda unidade, ser supraessencial, mente sobre toda mente, palavra sobre toda palavra. Transcende toda razão, toda intuição, todo nome. ${ }^{244}$

Ninguém o pode imaginar nem há palavras com que dar a entender o que Ele é, pois nada de quanto existe se pode comparar com Ele. (...) Todo conhecimento, em realidade, tem um ser como objeto. Aquele que é superior a todo objeto transcende também todo conhecimento. ${ }^{245}$

Não podemos alcançar com o pensamento nem com palavras o Uno, o Incognoscível, Supraessencial. ${ }^{246}$

Porque Deus é incognoscível, as essências dos seres também escapam ao conhecimento humano, pois estas se encontram no pensamento de Deus, que é a causa, origem e princípio de todas as coisas. É o que afirma Tomás em diferentes obras:

As essências das coisas nos são desconhecidas. ${ }^{247}$
Os princípios essenciais das coisas nos são ignorados. ${ }^{248}$

As formas essenciais por si mesmas são ignoradas. ${ }^{249}$

As diferenças essenciais nos são ignoradas. ${ }^{250}$

A ideia de que Deus contém em si as essências das coisas - que, portanto, escapam à capacidade de apreensão do homem - também é uma das marcas do pensamento do Pseudo Dionísio Areopagita. É por isso, diz, que as Escrituras chamam Cristo de Logos, o princípio de tudo, aquele por intermédio de quem todas as coisas foram feitas, como diz o Evangelho de João ${ }^{251}$. Sobre esse tema, Dionísio afirma:

Nosso conhecimento está longe de abarcar todos os mistérios divinos, muitos dos quais não estão ao alcance do entendimento. Somente as ordens superiores à nossa condição humana conhecem esses mistérios que são dignos de sua natureza divina. Muitos deles ultrapassam os seres mais elevados, de maneira que os conhece plenamente somente a Deidade, fonte de toda sabedoria. ${ }^{252}$

\footnotetext{
${ }^{243}$ Dos nomes divinos I.

${ }^{244}$ Dos nomes divinos I.

${ }^{245}$ Dos nomes divinos I.

${ }^{246}$ Dos nomes divinos I.

${ }^{247}$ Quaestiones disputatas de veritate q. 10, a. 1.

${ }^{248}$ In de anima $1,1,15$.

${ }^{249}$ Quaestiones disputatas de spiritualibus crituris, q. 11 ad 3.

${ }^{250}$ Quaestiones disputatas de veritate q. 4, a. 1 ad 8.

251 João I, 3.

${ }^{252}$ Da hierarquia eclesiástica VII.
} 
Ele que é o princípio supraessencial de toda ordem. ${ }^{253}$

Em resumo, é vida dos viventes, essência dos seres. Princípio e causa, por sua bondade, de toda vida e essência. Por sua mesma bondade produz e mantém em seu ser todas as coisas. ${ }^{254}$

Essa Bondade Sem Nome contém em si de maneira simples e indefinida todas as coisas antes que existam. ${ }^{255}$

Os arquétipos existem previamente em Deus como supraunidades. Ele é autor de todas as essências. O que chamamos "arquétipos ou exemplares" são em Deus as razões essenciais das coisas, que preexistem em Deus simplesmente. A teologia as chama "predefinições", vontades divinas e boas, definidoras e criadoras das coisas, segundo as quais aquele que é Supraessência predefiniu e produziu todas as coisas que são. ${ }^{256}$

As Santas Escrituras louvam a Deus como Logos não só porque é dispensador da razão, da inteligência e da sabedoria, mas também porque existem nele previamente as causas de todas as coisas e Ele as transcende por todas as partes, penetrando, como diz a Escritura, até o fim de todas as coisas. $^{257}$

Em seu poder transcendente, Ele está sobre todas as coisas e na supraessência contém todas as coisas antes que existam. ${ }^{258}$

No Comentário ao Credo dos Apóstolos, Tomás de Aquino, ao defender a necessidade da fé, fala do estado imperfeito do entendimento humano. Segundo ele, se o homem tivesse a capacidade de conhecer todo o visível e o invisível, poderia prescindir da fé. Porém, o intelecto humano é de tal maneira débil que nenhum filósofo pode conhecer perfeitamente sequer a natureza de uma mosca ${ }^{259}$.

Fica evidente, assim, que, para Tomás de Aquino, o homem não pode conhecer todas as coisas nem obter respostas para seus mais profundos questionamentos, como querem os intérpretes que, ao longo dos séculos, transformaram o Aquinate num filósofo racionalista, autor de um sistema filosófico acabado e defensor da autosuficiência da razão - algo como um pensador pré-iluminista ainda no século XIII. E é exatamente isso o que sugere o equívoco termo "tomismo"260. Bem diferente dessa

${ }^{253}$ Da hierarquia celeste IV.

${ }^{254}$ Dos nomes divinos I.

${ }^{255}$ Dos nomes divinos $\mathrm{I}$.

${ }^{256}$ Dos nomes divinos V.

${ }^{257}$ Dos nomes divinos VII.

${ }^{258}$ Dos nomes divinos VIII.

${ }^{259}$ Tomás de Aquino, Comentário ao Credo dos Apóstolos, prólogo.

${ }^{260}$ Pieper aponta esse erro: "Não pode haver um 'tomismo' porque a grandiosa afirmação que representa a obra de S. Tomás é grande demais para isso (...). S. Tomás nega-se a escolher algo; empreende o imponente projeto de 'escolher' tudo (...). A grandeza e a atualidade de Tomás consistem precisamente em que não se lhe pode aplicar um 'ismo', isto é, não pode haver propriamente um 'tomismo' ('propriamente', isto é, não pode haver enquanto se entenda por 'tomismo' uma especial direção doutrinária caracterizada por asserções e determinações polêmicas, um sistema escolar transmissível de 
imagem, porém, Tomás reconhece os limites da razão e a radical transcendência de Deus.

Recolhemos a seguir algumas considerações de Fran O'Rourke ${ }^{261}$, por serem bastante pertinentes em relação ao tema da negatividade em Tomás de Aquino.

Segundo O’Rourke, a teologia negativa assume, para Tomás de Aquino, uma função muito superior para o conhecimento de Deus. Ele indica as limitações da teologia positiva e apresenta como sua consequência a necessidade da teologia negativa e transcendente. A intenção não é de nenhum modo negativa: o propósito não é diminuir nossa apreciação do conhecimento já obtido, mas colocar Deus acima das nossas estimativas. Nós conhecemos Deus, de acordo com Tomás, apenas como primeiro princípio de todas as perfeições e como causa por sua bondade em todas as participações. O que Ele é em si mesmo permanece inescrutável e inefável. Deus difunde suas perfeições por via de similitude, mas permanece imparticipado, além de todas as coisas, em sua singularidade única. Como afirma Tomás:

Deus é maior do que tudo o que podemos afirmar, maior do que tudo o que podemos conhecer. E não apenas transcende nossa linguagem e conhecimento, mas está além da compreensão de qualquer mente, até das mentes angélicas, e além do ser de toda substância. ${ }^{262}$

Sob o entendimento do nosso intelecto - continua O'Rourke, interpretando Tomás -, apenas é possível captar o ser criado e finito, que é totalmente deficiente, em contraste com o Ser infinito e incriado. Devemos, portanto, compreender que Deus está além de tudo o que pode ser apreendido pelo intelecto. A via da negação se impõe, portanto, como mais válida, diz O’Rourke, citando frases de Tomás que se encontram no Comentário aos Nomes divinos de Dionísio:

O mais perfeito que nós podemos alcançar nesta vida a respeito do conhecimento de Deus é que ele transcende tudo o que pode ser concebido por nós e que nomear Deus através da remoção é o mais próprio (...). O modo primário de nomear Deus é através da negação de todas as coisas, uma vez que ele está além de tudo, e o qualquer coisa que é significada por qualquer nome é menos do que Deus é. ${ }^{263}$

As negações são absolutamente verdadeiras, enquanto as afirmações, embora não sejam falsas, são verdadeiras apenas relativamente, comenta O'Rourke. A perfeição

princípios doutrinais" (J. Pieper, Thomas Von Aquin: Leben und werk, citado por J. Lauand em "Método e linguagem no pensamento de Josef Pieper" (disponível em www.hottopos.com/videtur29).

${ }^{261}$ Fran O'Rourke, Pseudo-Dionysius and the metaphysics of Aquinas. Notre Dame: University of Notre Dame Press, 2005.

${ }^{262}$ Comentário aos Nomes Divinso I, 3

${ }^{263}$ Comentário aos Nomes Divinos I, 3. 
significada está de algum modo presente em Deus, mas, para ser afirmada verdadeiramente, ela deve ser concebida em seu mais supremo grau, livre de sua condição finita. De um lado, dizemos que Deus é em sua essência bom, sábio etc. De outro lado, removemos esses nomes a respeito do seu modo de significação. Cada uma dessas palavras ("sabedoria", "bondade" etc.) expressa, de acordo com a nossa maneira de conceber, uma definida maneira de ser que, limitada e separada, é imprópria no que se refere a Deus, em quem todas as perfeições subsistem na unificada e absoluta subsistência da divina essência.

\section{O’Rourke acrescenta:}

Através da dialética de afirmação e negação, emerge o sentido transcendente dos nomes aplicados a Deus. Como causa de todas as coisas, e de acordo como elas possuem uma semelhança com sua origem, os nomes de todas as coisas podem ser atribuídos a Ele, mas, na medida em que elas falham em representá-lo, nós removemos de Deus os nomes que nós impusemos e pronunciamos os seus opostos. Nomes afirmativos, Tomás enfatiza, são aplicados a Deus não de acordo com a mesma medida das criaturas, mas num sentido preeminente, como causa. E, por outro lado, os nomes são removidos de Deus não em razão de qualquer deficiência, mas per quemdam excessum, porque Ele possui as suas perfeições numa mais excelente maneira (...). A teologia positiva e a negativa são, portanto, propriamente destinadas à absoluta transcendência de Deus. No pensamento e na fala humana, esse valor eminentemente positivo da transcendência é mais efetivamente expressado pela predicação negativa. ${ }^{264}$

É importante destacar - como faz Pieper - que o elemento negativo da filosofia de Tomás de Aquino não conduz ao agnosticismo. Apesar das limitações do intelecto humano, Tomás afirma que "a inteligência penetra até a essência das coisas"265. Para Pieper, esses dois fatores - a insuficiência da razão e a sua capacidade de penetrar nas essências - são correlatos: "O fato de que o intelecto atinge as coisas manifesta-se em que ele se precipita em insondáveis profundezas de luz. Porque o espírito atinge o ser das coisas, experimenta a inesgotabilidade delas" 266 .

Pieper acrescenta:

O cognoscente é visto como "viator", um ser que está a caminho. Isso significa, por um lado: os seus passos têm sentido, não são, por princípio, vãos, mas aproximam-se de um objetivo. Isso, porém, não pode ser pensado sem o outro elemento: enquanto durar para o homem, na condição de ser existente, o "estar a caminho", permanecerá igualmente infindável o seu caminho de conhecimento. E essa estrutura de esperança do que indaga pelo ser das coisas, do conhecimento filosófico, funda-se, afirmemo-lo uma vez mais, no fato de o mundo ser creatura; o mundo, tanto quanto o próprio ser humano cognoscente ${ }^{267}$

\footnotetext{
${ }^{264}$ Fran O'Rourke, obra citada, p. 51-52.

265 Suma teológica I-II, 31, 5.

${ }^{266}$ J. Pieper, obra citada, p. 73.

${ }^{267}$ J. Pieper, obra citada, p. 74.
} 
Seja como for, ainda que consiga percorrer um longo trecho do caminho do conhecimento e apreender profundas verdades sobre Deus, o homem não pode chegar aos limites desse caminho e contemplar os seres tal como são em sua mais íntima estrutura. Uma importante consequência disso é que, dessa forma, cai por terra todo projeto racionalista radical, que exalta a onipotência da razão e confere a esta o poder de discernir todas as coisas. $\mathrm{O}$ aspecto negativo da filosofia de Tomás de Aquino é um "antídoto" contra essa tendência típica do pensamento ocidental, iniciada com a própria Escolástica: presente implicitamente já no De Trinitate de Boécio (480-524) 268 , passando por Anselmo (1033-1109), foi explicitada nos tempos modernos e consagrada pelo Iluminismo, encontrando a falência no século XX, quando duas guerras mundiais colocaram em dúvida a capacidade da razão de garantir o bem-estar da humanidade.

Curiosamente, esse caráter incognoscível de Deus - ao mesmo tempo luz imensa e mistério profundo - encontra-se perfeitamente expresso numa canção composta por Beto Guedes e Caetano Veloso, Luz e mistério, gravada na bela voz de Zizi Possi:

Oh, meu grande bem

Pudesse eu ver a estrada

Pudesse eu ter a rota certa

\footnotetext{
268 "Os opúsculos de Boécio - dos quais o principal é precisamente o De Trinitate - são as 'primícias do método escolástico' - e, por isso, Boécio é considerado 'um precursor de S. Tomás' (Steward e Rand). Já o título de seu livro (Como a Trindade é um único Deus e não três deuses) expressa o propósito de esclarecer racionalmente a verdade de fé. Certamente isso não é algo de novo. Agostinho e outros tinham escrito textos com o mesmo intuito. Aliás, Agostinho havia afirmado a necessidade de cooperação entre fé e razão com a célebre sentença do Sermão 43: 'Intellige ut credas, crede ut intelligas' ('Entende a fim de que creias, crê a fim de que entendas'). Para Boécio, o lema era: 'Fidem, si poteris, rationemque cojunge' ('Conjuga a fé e a razão'), conselho com que encerra uma carta ao papa João I. À primeira vista, nada de novo. A novidade, porém, está em que esse propósito tenha sido assumido explicitamente, programaticamente: aquilo que antes podia ser unicamente uma atitude fática tornava-se agora um princípio. Nova é também a radicalidade do projeto. No seu De Trinitate, encontram-se várias concepções platônicas e neoplatônicas; as dez categorias, os gêneros, as espécies e diversos outros conceitos de Aristóteles; todo tipo de análises filosóficas e de linguagem. Mas não hã nem sequer uma única citação ou referência à Bíblia, e isso num tratado teológico sobre a Santíssima Trindade. A novidade, porém, está em que esse propósito tenha sido assumido explicitamente, programaticamente: aquilo que antes podia ser unicamente uma atitude fática tornava-se agora um princípio. Nova é também a radicalidade do projeto. No seu De Trinitate, encontram-se várias concepções platônicas e neoplatônicas; as dez categorias, os gêneros, as espécies e diversos outros conceitos de Aristóteles; todo tipo de análises filosóficas e de linguagem. Mas não hã nem sequer uma única citação ou referência à Bíblia, e isso num tratado teológico sobre a Santíssima Trindade. Não que a Escolástica se caracterize por ser racional, não-bíblica, mas é preciso frisar aqui a especial importância dada à tarefa de conjugar razão e fé. Esse caráter inovador racional não passou despercebido a Tomás de Aquino. Na Introdução do seu comentário ao De Trinitate de Boécio, Tomás, a propósito do tema da Trindade, explica que há dois modos fundamentais de procedimento teológico: per auctoritates e per rationes. E que, se Ambrósio e Hilário enveredaram pelo primeiro, e se Agostinho mistura os dois procedimentos, Boécio segue decididamente o segundo: a radicalidade da investigação racional" (Jean Lauand, "Boécio e o De Trinitate" (disponível em www.hottopos.com/convenit5).
} 
Que levasse até dentro de ti

Oh, meu grande bem

Só vejo pistas falsas

É sempre assim

Cada picada aberta

Me tem mais fechado em mim

És um luar

Ao mesmo tempo luz e mistério

Como encontrar a chave

Desse teu riso sério?

Doçura de luz

Amargo e sombra escura

Procuro em vão

Banhar-me em ti

E poder decifrar teu coração

Oh, grande mistério

Meu bem, doce luz

Abrir as portas desse império teu

E ser feliz

Tomás afirma que é impossível conhecer plenamente o absoluto, o eterno, o necessário - ou seja, as coisas referentes a Deus. Afirma também a impossibilidade, para o entendimento do homem, de abarcar aquilo que é contingente, passageiro e instável, que faz parte das coisas humanas, do dia a dia da sociedade. Ou seja, não há como apreender a existência num conjunto de regras que determinem o modo certo de agir num determinado momento. Não existe um manual com princípios racionalmente elaborados que estabeleçam que a pessoa deve ou não dar esmolas em tal ocasião, que o governante tome esta ou aquela medida, que o professor use esta ou aquela metodologia, que o jogador chute a bola por cima ou por baixo do goleiro.

Daí que nos ocuparemos, a seguir, de alguns aspectos da doutrina da prudência no Aquinate, pois esta tem o dom de manifestar de modo privilegiado todo seu posicionamento filosófico. A brutal omissão da negatividade do pensamento tomasiano por parte de comentadores e epígonos caminha pari passu com o - também "incrível" silêncio sobre a principal das virtudes cardeais.

Tudo é contingente e depende da hora e do lugar em que ocorre a ação. Isso acontece até mesmo com aqueles valores considerados em si mesmos bons, como o amor e a justiça. Pois pode acontecer, como diz Tomás ${ }^{269}$, que o amor demonstrado a uma pessoa não seja conveniente num dado momento - por exemplo, se essa pessoa for tomada pela soberba ou pela desconfiança de que está sendo adulada. No que se refere à

\footnotetext{
${ }^{269}$ Suma teológica II-II, questão 49, artigo 7
} 
justiça, classicamente definida como o dar a outrem o que lhe é devido, ela não pode ser obedecida caso alguém se encontre na situação em que deve restituir uma faca ou um revólver a seu legítimo dono, estando este dominado pela fúria, por exemplo.

E mais: ainda segundo Tomás, nas ações contingentes, o verdadeiro pode se misturar ao falso, assim como o mal pode se mesclar ao bem, "por causa da variedade de situações em que se dão essas ações, nas quais o bem frequentemente está obstruído pelo mal e o mal se apresenta com aspecto de bem"270.

Isso mostra que o homem se encontra num mar de incertezas diante da instabilidade da existência, sem ter a segurança definitiva de que aquilo que faz é absolutamente certo e bom e sem saber se o que realiza terá consequências boas ou más. Essa condição humana é confirmada pela sabedoria de todos os tempos, a começar pelo Eclesiastes, que afirma:

Pois quem sabe o que é bom para o homem durante os poucos dias da sua vida de vaidade, os quais gasta como sombra?

Quem pode declarar ao homem o que será depois dele debaixo do sol? ${ }^{271}$

No dia da prosperidade, goza do bem; mas, no dia da adversidade, considera em que Deus fez tanto este como aquele, para que o homem nada descubra do que há de vir depois dele. ${ }^{272}$

Porque este (o homem) não sabe o que há de suceder; e, como há de ser, ninguém há que lho declare. ${ }^{273}$

Deveras me apliquei a todas essas coisas para claramente entender tudo isto: que os justos e os sábios e os seus feitos estão nas mãos de Deus; e, se é amor ou se é ódio que está à sua espera, não o sabe o homem. Tudo lhe está oculto no futuro. ${ }^{274}$

Também nesse ponto o islamismo concorda com o Eclesiastes, ao afirmar:

Por certo, junto de Allah está a ciência da Hora, e Ele faz descer a chuva; e sabe o que há nas matrizes. E pessoa alguma se inteira do que logrará amanhã, e pessoa alguma se inteira de em qual terra morrerá. Por certo, Allah é Onisciente, Conhecedor. ${ }^{275}$

Outra tradição filosófico-religiosa, iniciada com o Tao te ching - livro fundador do taoísmo, atribuído a Lao-tsé, pensador chinês do século VI antes de Cristo -, se refere à mesma instabilidade e incerteza das coisas humanas:

Desgraça! Em ti apóia-se a felicidade

\footnotetext{
${ }^{270}$ Suma teológica II-II, questão 49, artigo 8. Tradução de Jean Lauand.

${ }^{271}$ Eclesiastes 6:12.

${ }^{272}$ Eclesiastes 7:14.

${ }^{273}$ Eclesiastes 8:7.

${ }^{274}$ Eclesiastes 9:1.

${ }^{275}$ Alcorão 31:34, tradução de Helmi Nasr.
} 
Felicidade! Em ti encosta-se a desgraça

Quem lhe conhece os limites?

$\mathrm{Na}$ anomia... o normal passa por anormal

O bom passa por simulacro

O desvio do homem... teus dias teimosamente duram. ${ }^{276}$

E também:

Coragem com ousadia então morte

Coragem sem ousadia então sobrevivência

Ambas... ora benéficas ora maléficas

Aquilo que o céu abomina alguém sabe a razão? ${ }^{277}$

Não apenas as religiões, mas também a arte revela a perturbadora condição humana de incerteza diante da vida. O poeta português Fernando Pessoa (1888-1935) sentiu esse drama e assim o expressou:

Vê de longe a vida.

Nunca a interrogues.

Ela nada pode

Dizer-te. A resposta

Está além dos deuses. ${ }^{278}$

Exatamente para enfrentar a incerteza e a insegurança da existência humana condição que atinge todos os homens em todas as épocas, desde a Antiguidade até hoje - é que Tomás de Aquino elabora a doutrina da prudência ${ }^{279}$, que ele define como "a reta razão aplicada ao agir". Segundo Tomás, à prudência corresponde não apenas a consideração racional, mas também a aplicação à ação, daí por que o Aquinate a considera uma virtude da razão prática, e não da razão especulativa, que busca o conhecimento teórico. "Prudência é ver a realidade e, com base nessa visão, tomar a decisão certa”, ensina Jean Lauand ${ }^{280}$.

Enquanto a virtude da sabedoria ou da ciência se ocupa do que é necessário e a virtude da arte ou da técnica se dedica à matéria exterior - a construção de uma casa, por exemplo -, a virtude da prudência diz respeito às ações humanas. Não cabe a ela determinar o fim das virtudes morais, tarefa própria da razão, mas sim definir os meios para chegar àquele fim, meios que são indeterminados e variados, de acordo com as

\footnotetext{
${ }^{276}$ Lao-tsé, Escritos do curso e sua virtude (Tao te ching), 58, tradução de Mário Bruno Sproviero.

${ }^{277}$ Lao-tsé, obra citada, 73.

${ }^{278}$ Fernando Pessoa, Poesias, organização de Sueli Barros Cassal, Porto Alegre, L\&PM, 2008, página 108.

${ }^{279}$ Tomás de Aquino expôs a doutrina da prudência nas questões 47 a 56 da segunda parte da Segunda Parte da Suma teológica. Essas questões - mais o artigo 1 da questão 120, que trata do mesmo tema estão reunidas em A prudência - A virtude da decisão certa (Martins Fontes, 2005), tradução de Jean Lauand, de que foram extraídos os trechos citados neste capítulo.

${ }^{280}$ Jean Lauand, "A prudentia em Tomás de Aquino: atualidade de uma análise medieval”, em Filosofia, linguagem, arte e educação, p. 153.
} 
pessoas e as circunstâncias ${ }^{281}$. "Este é o papel da prudência: aplicar os princípios universais às conclusões particulares do âmbito do agir.",282

Esse agir se refere às realidades singulares. Nesse campo, diz Tomás, o homem não pode se guiar por verdades absolutas e necessárias, mas somente pelo que acontece na maioria dos $\operatorname{casos}^{283}$. No mundo dos particulares e contingentes, dá-se uma diversidade de situações tão grande que é impossível estabelecer uma lei que não falhe em algum caso concreto ${ }^{284}$. O homem "não pode abarcar com certeza num simples olhar a verdade das coisas, especialmente se se trata de suas ações, que são contingentes",285.

Diante do contingente, do instável e do precário, o homem, a fim de se conduzir bem, precisa recorrer à prudência ${ }^{286}$. Como afirma Lauand, embora haja um certo e um errado objetivos, a condição humana é tal que, muitas vezes, "não dispomos de regras operacionais concretas para decidir" ${ }^{, 287}$. A prudência ajuda o homem a encontrar essa ação certa, à semelhança de um jogo de xadrez, em que a melhor jogada deve ser decidida no instante em que se dá o lance, diante da "visão da realidade" da particular situação de determinado tabuleiro ${ }^{288}$.

\footnotetext{
${ }^{281}$ Suma teológica II-II, 47, 15.

${ }^{282}$ Suma teológica II-II, 47, 6.

${ }^{283}$ Suma teológica II-II, 49, 1.

${ }^{284}$ Suma teológica II-II, 120, 1

${ }^{285}$ Suma teológica II-II, 51, 1.

286 Jean Lauand nota que prudência (prudentia, em latim) é uma das tantas palavras que sofreram "desastrosas transformações semânticas" ao longo dos séculos. Segundo Lauand, atingida pelo subjetivismo metafórico e pelo gosto do eufemismo, prudência deixou de significar a grande virtude celebrada pelos pensadores antigos para se transformar na temerosa cautela, muitas vezes guiada por interesses oportunistas e egoístas, com que uma pessoa reage a uma situação, levando-a até mesmo a não tomar nenhuma decisão. "Se hoje a palavra prudência tornou-se aquela egoísta cautela da indecisão (em cima do muro), em Tomás, ao contrário, prudentia expressa exatamente o oposto: é a arte de decidir corretamente" (Tomás de Aquino, A prudência - A virtude da decisão certa, introdução, páginas VII-X). 287 Jean Lauand, em Tomás de Aquino, A prudência - A virtude da decisão certa, Introdução, página XIII.

${ }^{288}$ Lauand cita uma reflexão do jagunço Riobaldo, personagem de Grande sertão: veredas, de Guimarães Rosa, que ilustra perfeitamente a ideia de que existe um agir correto, que o homem deve buscar a cada momento, embora seja difícil encontrá-lo, e para isso é necessária a prudentia: "Só o que eu quis, todo o tempo, o que eu pelejei para achar, era uma só coisa - a inteira - cujo significado e vislumbrado dela eu vejo que sempre tive. A que era: que existe uma receita, a norma dum caminho certo, estreito, de cada uma pessoa viver - e essa pauta cada um tem - mas a gente mesmo, do comum, não sabe encontrar; como é que sozinho, por si, alguém ia poder encontrar e saber? Mas, esse norteado, tem. Tem que ter. Se não, a vida de todos ficava sendo sempre o confuso dessa doideira que é. E que: para cada dia, e cada hora, só uma ação possível da gente é que consegue ser a certa. Aquilo está no encoberto: mas, fora dessa consequência, tudo o que eu fizer, o que o senhor fizer, o que o beltrano fizer, o que todo-o-mundo fizer, ou deixar de fazer, fica sendo falso, e é o errado. Ah, porque aquela outra é a lei, escondida e vivível mas não achável, do verdadeiro viver: que para cada pessoa, sua continuação, já foi projetada, como o que se põe, em teatro, para cada representador - sua parte, que antes já foi inventada, num papel" (Guimarães Rosa, Grande sertão: veredas, Rio de Janeiro, José Olympio, $5^{\text {a }}$ edição, página 366.). Citado por Jean Lauand, em Tomás de Aquino, A prudência - A virtude da decisão certa, Introdução, páginas XIII e XIV.
} 
Para que a virtude da prudência - que não é inata, mas procede do ensino e da experiência $^{289}$ - seja praticada adequadamente, é preciso cultivar e acionar as suas oito partes (ou funções), que, uma vez ativas, levam o indivíduo a ter - na medida do possível - um "límpido conhecimento"290 da realidade e, com base nesse conhecimento, a agir corretamente. Essas partes ou funções são: memória, inteligência, docilidade, sagacidade, razão (que se referem à dimensão cognoscitiva da prudência, ligada ao conhecimento), previdência, circunspecção e prevenção (relacionadas à dimensão de comando, que aplica o conhecimento à ação).

Concebida com o objetivo de orientar o ser humano em meio à instabilidade típica da vida terrena, a doutrina tomasiana da prudência constitui um instrumento especialmente importante para o homem do século XXI, que - talvez mais do que em qualquer outro momento da história - vive a desorientação e as incertezas de uma época marcada pelo relativismo, a superficialidade e a perda de identidade. Esse último aspecto - a perda de identidade - é descrito com precisão pelo sociólogo Stuart Hall ${ }^{291}$. Ao discutir a concepção de identidade do sujeito pós-moderno, ele cita que, na pósmodernidade, o sujeito - que no passado vivia com uma identidade unificada e estável se torna fragmentado, composto não de uma única, mas de várias identidades, algumas vezes contraditórias ou não-resolvidas. O próprio processo de identificação, através do qual os indivíduos se projetam em suas identidades culturais - diz Hall - tornou-se mais provisório, variável e problemático:

\footnotetext{
Esse processo produz o sujeito pós-moderno, conceitualizado como não tendo uma identidade fixa essencial ou permanente. A identidade torna-se uma "celebração móvel": formada e transformada continuamente em relação às formas pelas quais somos representados ou interpelados nos sistemas culturais que nos rodeiam. É definida historicamente, não biologicamente. $\mathrm{O}$ sujeito assume identidades diferentes em diferentes momentos, identidades que não são unificadas ao redor de um "eu" coerente. Dentro de nós há identidades contraditórias, empurrando em diferentes direções, de tal modo que nossas identificações estão sendo continuamente deslocadas. Se sentimos que temos uma identidade unificada desde o nascimento até a morte, é apenas porque construímos uma cômoda estória sobre nós mesmos ou uma confortadora "narrativa do eu". A identidade plenamente unificada, completa, segura e coerente é uma fantasia. Ao invés disso, à medida em que os sistemas de significação e representação cultural se multiplicam, somos confrontados por uma multiplicidade desconcertante e cambiante de identidades possíveis, com cada uma das quais poderíamos nos identificar ao menos temporariamente. ${ }^{292}$
}

\footnotetext{
${ }^{289}$ Suma teológica II-II, 47, 15.

290 Jean Lauand, em Tomás de Aquino, A prudência - A virtude da decisão certa, Introdução, página X.

${ }^{291}$ Stuart Hall, A identidade cultural na pós-modernidade, tradução de Tomaz Tadeu da Silva e Guacira Lopes Louro, Rio de Janeiro, DP\&A, 2005, 10ª edição.

${ }^{292}$ Stuart Hall, obra citada, p. 12-13.
} 
Num meio como esse - em que toda forma de pensamento e de comportamento parece legítima -, o homem tende a ter esmaecida a sua visão da realidade e enfraquecido o "límpido conhecimento" do ser das coisas, com base no qual deve tomar suas decisões. A atitude "politicamente correta", por exemplo, faz com que as pessoas ajam não por si mesmas, mas movidas por um conceito abstrato que, dada a natureza instável das situações humanas, às vezes pode ser adequado e outras vezes, inadequado. Da mesma forma, a piedade é má conselheira, pois agir com base nela pode produzir o mal - como ocorre quando se dá esmolas para um menino de rua, que as usará para comprar drogas ou as entregará para um adulto que a explora.

Para agir adequadamente, não servem o "politicamente correto", a piedade ou qualquer outro sentimento, mas sim a visão correta da realidade, diria Tomás. E a essa visão têm acesso aqueles indivíduos que desenvolvem a virtude da prudência. Esses, sim, exercem plenamente sua autonomia e sua liberdade, pois não agem ao sabor da ocasião ou de acordo com nenhum preceito preestabelecido, mas unicamente segundo sua própria consciência, firmada na realidade.

Lauand $^{293}$ afirma que renunciar à prudência - ou seja, agir não com base no conhecimento da realidade, mas segundo qualquer outro critério - significa uma despersonalização do indivíduo, que deixa de exercer sua autonomia, rebaixa-se à condição de "menor de idade", incapaz de tomar decisões, e transfere a direção de sua vida para outra instância, como a igreja e o estado. Tal processo de despersonalização, cita Lauand, é descrito pelo Grande Inquisidor - personagem de Dostoiévski em $O s$ irmãos Karamázovi -, que vê "o homem esmagado sob essa carga terrível: a liberdade de escolher" e apresenta o povo que se deixou escravizar, preferindo "até mesmo a morte à liberdade de discernir entre o bem e o mal". "Reduzi-nos à servidão, contanto que nos alimenteis", suplicam os subjugados, abdicando da prudência ${ }^{294}$.

\footnotetext{
Uma das mais perigosas formas de renúncia a enfrentar a realidade (ou seja, a renúncia à prudentia) é trocar essa fina sensibilidade de discernir o que, naquela situação concreta, a realidade exige por critérios operacionais rígidos, como num "Manual de escoteiro moral" ou, no campo do direito, num estreito legalismo à margem da justiça. É também o caso do radicalismo adotado por certas propostas religiosas. Tal como o Ministério do Vício e da Virtude do regime Taliban, algumas comunidades cristãs - em vez de afirmar o direito (e o dever) do fiel de discernir o que é bom em cada situação pessoal
}

\footnotetext{
${ }^{293}$ Tomás de Aquino, A prudência - A virtude da decisão certa, Introdução, página XXIII.

294 Fiódor Dostoiévski, Os irmãos Karamázovi, citado por Jean Lauand em Tomás de Aquino, A prudência - A virtude da decisão certa, Introdução, página XV.
} 
concreta - simplificam grosseiramente: em caso de dúvida, é pecado e pronto! $!^{295}$

Como dissemos, curiosamente, a pregação da Igreja Católica Apostólica Romana - que canonizou Tomás de Aquino em 1323 e até tornou seus ensinamentos oficiais - tem ignorado a doutrina tomasiana da prudência, e nem sequer dispomos de uma palavra para denominá-la, uma vez que a palavra "prudência" perverteu-se. Esse comportamento da Igreja é compreensível, tendo em vista que o indivíduo autenticamente autônomo e livre está menos sujeito a se submeter às diretrizes estabelecidas pela hierarquia eclesiástica, que dessa forma perde importância e poder. Ao contrário, interessa a essa hierarquia enfatizar exatamente o pretenso racionalismo de Tomás de Aquino, que seria fonte de verdades acabadas e certezas absolutas. O mesmo vale para todas as demais denominações religiosas - e não apenas para o catolicismo -, sempre ávidas por ditar normas e padrões de vida para seus seguidores. Porém, o elemento negativo do pensamento de Tomás descarta o racionalismo, revela o caráter de mistério e de inesgotabilidade das coisas e, diante disso, convoca o homem a cultivar a prudência, ou seja, a plena autonomia.

No dizer de Lauand, tal é a especificidade de Tomás de Aquino entre os santos católicos - esta também esquecida pela Igreja. Assim como santo Antônio é conhecido por promover casamentos e santo Expedito socorre os fiéis nas causas urgentes, Tomás é o santo que ensina o homem a viver sem medo e com liberdade, assumindo os seus atos praticados com plena autonomia, sem nenhuma dependência externa. "Afirmar a prudentia é afirmar que cada pessoa é protagonista de sua vida, só ela é responsável, em suas decisões livres, por encontrar os meios de atingir seu fim: a sua realização", destaca Lauand ${ }^{296}$.

Além de proteger o homem contra a ingerência da igreja no âmbito de sua autonomia, a doutrina da prudência é também um freio a todo tipo de totalitarismo praticado pelo estado. Dada a instabilidade das coisas humanas, nenhum governante pode pretender ter certeza absoluta de que a sociedade deve ser conduzida desta ou daquela forma. Qualquer medida tomada com base em certezas absolutas do governo será sempre um atentado contra a autonomia dos cidadãos. Diante das incertezas típicas de comandar, cabe também ao governante cultivar a prudência, a fim de agir

\footnotetext{
${ }^{295}$ Jean Lauand, "A prudentia em Tomás de Aquino: atualidade de uma análise medieval”, em Filosofia, linguagem, arte e educação, p. 154.

${ }^{296}$ Obra citada, página XXI.
} 
corretamente em cada caso específico. Por isso Tomás considera que "a prudência de reinar está entre as espécies de prudência"297.

A prudentia tomasiana é, assim, um convite ao homem contemporâneo para que exerça plenamente sua autonomia e liberdade e não se despersonalize diante do relativismo pós-moderno. Ela oferece a possibilidade de um agir seguro em meio a tantas incertezas. Permite também o livramento em relação às várias formas de totalitarismos e autoritarismos que diariamente tentam dominar mentes e consciências.

Mas o elemento negativo do pensamento de Tomás de Aquino - que está na origem da doutrina da prudência - não apenas traz importantes reflexões para o homem contemporâneo. Ele implica também sérias consequências para a teologia, a filosofia e a educação.

$\mathrm{Na}$ área da teologia, a negatividade em Tomás de Aquino representa uma reação contra um movimento que, estranho ao cristianismo original, sempre de novo ameaça o pensamento teológico - o racionalismo. Traduzido em doutrinas que expressam as certezas da teologia, esse racionalismo dominante no meio cristão é responsável, em boa medida, pela intransigência e intolerância de pensadores e líderes, que resultaram em desastrosos acontecimentos ao longo dos séculos, desde as Cruzadas e a Inquisição até as atuais divisões entre as denominações cristãs.

Entretanto, a Bíblia está repleta de exemplos que corroboram a ideia de que o cristianismo está muito distante do racionalismo, de que não é possível estabelecer certezas absolutas e de que o Evangelho não autoriza ninguém a impor regras e determinações aos outros - ao contrário, incentiva o indivíduo a exercer livremente sua autonomia.

No Evangelho de Lucas, por exemplo, está registrado o diálogo de Jesus Cristo com um intérprete da lei ${ }^{298}$, que, a fim de testá-lo, lhe perguntou o que é preciso fazer para herdar a vida eterna. Cristo responde com outra pergunta: "O que está escrito na lei?". O homem se refere ao mandamento "Amarás o teu próximo como a ti mesmo" e Cristo diz: "Respondeste corretamente. Faze isso e viverás". Mas o intérprete da lei insiste com novo questionamento: "Quem é o meu próximo?".

Precisamente aqui se nota o caráter antirracionalista de Cristo. Diante da pergunta objetiva, ao invés de dar pormenorizadas explicações sobre as características

\footnotetext{
${ }^{297}$ Suma teológica II-II, 50, 1. Além da prudência de reinar, as outras "partes subjetivas" da prudência são a prudência política (a conduta do homem diante dos governantes), a prudência doméstica (referente à condução da família) e a prudência militar (que diz respeito à defesa contra os ataques dos inimigos).

${ }^{298}$ Lucas 10:25-37.
} 
que definem "o próximo" - como faria um Aristóteles, por exemplo -, Cristo conta uma história, uma singela parábola desprovida de dados cientificamente comprováveis, a famosa parábola do samaritano. Narrou que um homem descia de Jerusalém para Jericó e foi abordado por ladrões, que o roubaram e o espancaram, deixando-o semimorto. Passando pelo caminho, um sacerdote viu o homem e não se incomodou. O mesmo ocorreu com um levita, que também não se importou com o estado da vítima. Já um samaritano, de passagem pelo mesmo caminho, se compadeceu do infeliz, aplicou-lhe óleo e vinho nas feridas e levou-o para uma hospedaria, a fim de que se recuperasse. Ao final da narrativa, Cristo sugeriu que o intérprete da lei fizesse o mesmo, sem dar sequer uma conceituação sobre o que é "o próximo"299.

Outra passagem valiosa para mostrar o caráter antirracionalista do cristianismo se encontra no mesmo Evangelho de $\operatorname{Lucas}^{300}$. Nela, um homem pede que Cristo interfira na divisão de uma herança de família e ordene que o irmão a divida com ele. A resposta de Cristo foi breve mas reveladora: "Homem, quem me constituiu juiz ou partidor entre vós?”. Ao invés de usar sua autoridade para fazer prescrições e impor regras, o fundador do cristianismo deixou a tarefa de distribuição da herança por conta dos homens, que têm autonomia para fazer isso, sem necessitar de uma iluminação especial e de mandamentos específicos. É uma demonstração de que o Evangelho não estabelece certezas para o cotidiano dos seres humanos, mas deixa que estes descubram por si mesmos a ação mais adequada para cada situação específica ${ }^{301}$.

O Evangelho de João relata um episódio em que Jesus Cristo restituiu a visão a um cego de nascença ${ }^{302}$. As autoridades religiosas da época condenaram a atitude, considerando que Cristo pecara porque operara o milagre num dia de sábado - o que seria proibido pela lei judaica. E chegaram a expulsar da sinagoga o ex-cego. Sabendo disso, Cristo encontrou o homem e revelou: "Eu vim a este mundo para juízo, a fim de

\footnotetext{
${ }^{299}$ Cf. Jean Lauand, "Os 'se' das línguas semitas e o Evangelho revisitado - O bom samaritano, o bom estalajadeiro ou o bom assaltante? (www.hottopos.com/notand16/lauand.pdf).

${ }^{300}$ Lucas 12:13-14.

${ }^{301}$ Jean Lauand usa a mesma passagem bíblica para apontar uma diferença essencial entre o cristianismo e o islamismo. Enquanto Cristo se recusa a estabelecer regras para a divisão da herança, o Alcorão traz uma série de cálculos para resolver justamente a mesma questão. A sura 4, por exemplo, diz, entre outras determinações: "Allah vos ordena o seguinte no que diz respeito a vossos filhos: que a porção do varão equivalha à de duas mulheres. Se estas são mais de duas, corresponder-lhes-ão dois terços da herança. Se é filha única, a metade". Lauand acrescenta que os cálculos para a partilha da herança determinados pelo Alcorão são tão intrincados que deram origem à álgebra, uma ciência tipicamente árabe, criada no século IX por Muhammad Ibn Musa Al-Khwarizmi, membro da Casa da Sabedoria, uma academia científica situada em Bagdá, e autor do Al-Kitab al-muhtasar fy hisab al-jabr wa al-muqabalah ("Livro breve para o cálculo da jabr e da muqabalah"), livro fundador da álgebra (Jean Lauand, "Ciência e Weltanschauung - A álgebra como ciência árabe”, em Filosofia, linguagem, arte e educação, páginas 85-99).

302 João 9:1-41.
} 
que os que não vêem vejam e os que vêem se tornem cegos",303. Ouvindo essa declaração, um dos religiosos perguntou: "Por acaso também nós somos cegos?". A resposta de Cristo foi: "Se fôsseis cegos, não teríeis nenhum pecado, mas, porque agora dizeis 'nós vemos', subsiste o vosso pecado"304.

Deve-se refletir bem nessa alegoria de Cristo. A expressão "os que vêem" pode muito bem ser traduzida por "os que têm certezas absolutas", que por isso prescrevem normas de comportamento para seus semelhantes. As pessoas que "enxergam" tendem a achar que estão acima das que "não enxergam" e podem conduzi-las segundo suas próprias convicções, gerando o autoritarismo, a intolerância e o totalitarismo. Já "os que não vêem" são aqueles que reconhecem a insuficiência da razão para obter certezas que levem à prescrição de regras de conduta para cada questão do dia a dia. Estes são tratados por Cristo com benevolência, enquanto aqueles que dizem enxergar são classificados, em outro trecho das Escrituras, como "cegos guias de cegos"305.

Acrescente-se a isso que Cristo sempre ensinou seus discípulos falando por meio de parábolas, alegorias e metáforas. Comparou o reino de Deus a um tesouro escondido no campo, a uma árvore, a uma rede de pesca, por exemplo, e nunca deu explicações racionais sobre os mistérios divinos. Evidenciou, com isso, que certas realidades não podem ser percebidas pelos homens, que devem sempre ter consciência de suas limitações e não ficar buscando respostas lógicas para tudo.

Como se não bastassem essas evidências, pode-se lembrar ainda outras passagens das Escrituras que também expressam - contra a tendência racionalista da teologia contemporânea - a insuficiência do intelecto humano para compreender as coisas divinas e estabelecer certezas. Em Eclesiastes, por exemplo, lê-se:

Tudo fez Deus formoso no seu devido tempo; também pôs a eternidade no coração do homem, sem que este possa descobrir as obras que Deus fez desde o princípio até ao fim. ${ }^{306}$

Tudo isso experimentei pela sabedoria; e disse: tornar-me-ei sábio, mas a sabedoria estava longe de mim. O que está longe e mui profundo, quem o achará? $?^{307}$

Então, contemplei toda a obra de Deus e vi que o homem não pode compreender a obra que se faz debaixo do sol; por mais que trabalhe o homem para a descobrir, não a entenderá; e, ainda que diga o sábio que a virá a conhecer, nem por isso a poderá achar. ${ }^{308}$

\footnotetext{
303 João 9:39.

304 João 9:41.

${ }^{305}$ Mateus 15:14.

${ }^{306}$ Eclesiastes 3:11.

${ }^{307}$ Eclesiastes 7:23-24.

${ }^{308}$ Eclesiastes 8:17.
} 
O profeta Isaías transmite a mesma ideia:

Porque os meus pensamentos não são os vossos pensamentos nem os vossos caminhos, os meus caminhos, diz o Senhor, porque assim como os céus são mais altos do que a terra, assim são os meus caminhos mais altos do que os vossos caminhos e os meus pensamentos, mais altos do que os vossos pensamentos. $^{309}$

No Novo Testamento, o apóstolo Paulo compõe um canto em que manifesta claramente o caráter de negatividade e de mistério das coisas divinas:

Ó, profundidade da riqueza da sabedoria e do conhecimento de Deus; como são insondáveis as suas decisões e inescrutáveis os seus caminhos. Quem, pois, conheceu a mente do Senhor? Ou quem se tornou seu conselheiro? Ou quem deu a Ele e restituiu a Ele? $?^{310}$

Constata-se, assim, que a teologia, ao se deixar influenciar por um racionalismo que exige certezas absolutas, não só se afasta do caráter de mistério e de incognoscibilidade do cristianismo original como também é a fonte do radicalismo religioso tão presente no mundo atual. A pretensa convicção de que tal doutrina é a certa gera a arrogância, a intolerância e, em casos extremos, o preconceito e o ódio. Nada mais distante da perspectiva cristã, fundada na paz, na concórdia, no amor e no antirracionalismo, que é contrário a convicções radicais. Nesse sentido, a obra de Tomás de Aquino, com seu elemento negativo, contribui para revestir o pensamento teológico atual de uma roupagem menos lógica e científica e mais alegórica e metafórica, com o que ele poderá fazer avanços seguros no conhecimento do sagrado.

Tomás, tantas vezes acusado injustamente de racionalismo, assume uma theologia negativa, destaca Lauand:

Esse caráter "negativo" informa seu modo de fazer teologia, uma teologia essencialmente bíblica. Contra as rationes necessariae de um Anselmo, contra a pretensão de deduzir logicamente as verdades da fé, Tomás afirma o mistério para o homem, contraponto da liberdade de Deus: "Não há nenhum argumento de razão naquelas coisas que são de fé" (In III Sent. d. 1, q. 1, a 3). E, na questão "Se Deus teria se encarnado se não tivesse havido o pecado do homem", Tomás recolhe como objeções os argumentos tradicionais na Escolástica: "Sim, a Encarnação necessariamente ocorreria, pois a perfeição pressupõe a união do primeiro - Deus - com o último, o homem"; ou "Seria absurdo supor que o pecado tivesse trazido para o homem a vantagem da Encarnação e que, portanto, necessariamente teria havido a Encarnação, mesmo sem o pecado". Tomás, porém, em sua resposta, refuta categoricamente a pretensão de clareza no bojo dessas objeções, afirmando:

\footnotetext{
${ }^{309}$ Isaías 55:8-9.

${ }^{310}$ Romanos 11:33-35.
} 
"A verdade sobre essa questão só pode conhecê-la Aquele que nasceu e se entregou porque quis". 311

Com boa dose de ironia, Pieper, no capítulo IV de Scholastik, afirma que, em contraste com o pensamento negativo de Tomás, Anselmo pretende elaborar a teologia dos "tinha que". Em seu livro Cur Deus homo?, o arcebispo da Cantuária - que, nota Pieper, não leu o Pseudo Dionísio Areopagita, pois em toda sua obra o cita uma única vez, e ainda assim para criticá-lo - explica que havia um número perfeito de criaturas adoradoras de Deus e que, com a queda dos anjos, esse número de caídos tinha que ser substituído pelo homem, que, portanto, tinha que ser redimido. Para isso, Jesus Cristo tinha que encarnar, tinha que morrer na cruz, tinha que ressuscitar, tinha que... Já para Tomás, as rationes necessariae são impossíveis simplesmente porque tudo se apoia na liberdade de Deus: Deus fez a encarnação e a redenção porque quis e como quis.

No contraste entre Tomás e Anselmo, percebe-se a diferença que faz o pensamento do Pseudo Dionísio Areopagita. Os pensadores influenciados por ele como Tomás de Aquino - trazem a marca da negatividade, do mistério e da incognoscibilidade. Por sua vez, aqueles que não leram a obra do Pseudo Dionísio Areopagita, a exemplo de Anselmo, tendem ao racionalismo e à tentativa de explicar todas as coisas, mesmo as insondáveis.

Note-se que o racionalismo exacerbado conduz tanto à racionalidade da fé, com suas desastrosas consequências, como ao ceticismo. Trata-se da mesma postura de inconformidade diante do desconhecido, com uma pequena variação: enquanto o racionalista cristão nega o mistério e a todo custo tenta enquadrar a fé dentro de moldes lógicos, o racionalista cético, uma vez que não é capaz de dominar racionalmente as coisas e compreendê-las totalmente, suspende o juízo e sequer considera a possibilidade da transcendência.

Já na área da filosofia, o racionalismo também fez estragos, contra os quais o pensamento negativo de Tomás de Aquino - o "lado Dionísio" do Aquinate representa, assim como ocorre na teologia, um excelente "antídoto". A tal ponto se desenvolveu o racionalismo que o homem contemporâneo é levado a pensar que pode conhecer todas as coisas com a força do seu entendimento, como sugerem os

\footnotetext{
311 Jean Lauand, "S. Tomás de Aquino e o Logos Criador, fundamento do conhecimento e do mistério" (disponível em www.jeanlauand.com/dominicanos.doc). Conferir também Josef Pieper, Scholastik, München, DTV, 1978. O capítulo XI é indispensável para este tema).
} 
racionalistas mais radicais, e a considerar inexistente tudo o que ultrapassa o seu entendimento, não admitindo nada que não consiga apreender ${ }^{312}$.

No entanto, a filosofia negativa de Tomás de Aquino está a mostrar que, embora possa conhecer muitas coisas, o filósofo jamais chegará ao conhecimento cabal de qualquer objeto de estudo, que sempre permanecerá inesgotável ${ }^{313}$. Mostra também um equívoco da filosofia contemporânea. Esta, ao desconsiderar o sagrado, impôs uma barreira diante de si mesma, que a impede de conhecer mais profundamente o mundo.

Deliberadamente limitada apenas ao que o homem pode apreender com a razão, a especulação filosófica se tornou incapaz de refletir sobre o sobrenatural e, dessa forma, atingir o que Martin Buber chama de "realidade inteira, sem cortes nem abreviações" ${ }^{\text {314 }}$. Ou seja, ao mesmo tempo em que busca conhecer todas as coisas, o racionalismo exacerbado do século XXI se encontra limitado nesse objetivo, porque não ultrapassa os limites da razão para avançar no conhecimento do imaterial, onde se encontram as respostas mais profundas para o mundo, a vida e os seres. Por mais que investigue as coisas terrenas, ele jamais se aproximará do princípio de todas as coisas uma das mais intrigantes questões filosóficas -, pois esse princípio não está matéria, e sim naquele que deu origem à matéria e que subsiste acima do temporal e do material.

Portanto, a filosofia contemporânea, se deseja conhecer "todas as coisas", deve atentar também para aquela dimensão abandonada e esquecida pelos filósofos de hoje o supra-racional -, que, embora radicalmente transcendente e incognoscível, pode ser

\footnotetext{
${ }^{312}$ Numa entrevista à revista Veja, o matemático norte-americano John Allen Paulos, da Universidade de Temple, na Filadélfia, nos Estados Unidos, criticou a teologia porque esta não segue o mesmo rigor das provas lógicas. "A lógica tem que ser rigorosa. Os argumentos teológicos não seguem esse rigor. Eles pulam de A para B, mas há um grande abismo entre os dois termos", ele declarou (revista Veja, edição 2065, ano 41, número 24, de 18 de junho de 2008, páginas 11, 14 e 15, entrevista a Jerônimo Teixeira). Certamente, o Pseudo Dionísio Areopagita e Tomás de Aquino responderiam que, sem dúvida, é inegável que existe um abismo entre Deus, absolutamente transcendente, e o homem. No entanto, isso não quer dizer que Deus não exista, mas sim que é inalcançável ao pensamento humano. Diriam ainda que, embora acima da razão humana, Deus pode ser objeto da especulação do homem e pode até ser parcialmente conhecido, através das obras criadas. É curioso que o ser humano discuta se Deus existe ou não, porque Deus, de acordo com Dionísio e Tomás, é a pura existência, é a existência em si, enquanto o homem existe apenas porque participa daquela existência, recebe de Deus a existência. Ou seja, o homem não existe por si, mas tem a existência porque esta lhe foi concedida por aquele que é a existência.

${ }^{313} \mathrm{Em}$ contraste com os racionalistas que confiam na capacidade da razão de conhecer todas as coisas, há cientistas que reconhecem a limitação do conhecimento humano. Em entrevista ao jornal $O$ Estado de $S$. Paulo, o neurocientista brasileiro Miguel Nicolelis, da Universidade Duke, nos Estados Unidos, comparou a ciência a uma longa corrida de revezamento, em que o "bastão" é passado de geração em geração, sem que quem está no meio da prova veja o final. "Do ponto de vista filosófico, na realidade (essa corrida) não tem (um final), porque estamos tentando explicar questões muito profundas, muito complexas. Dificilmente vamos chegar de uma maneira rápida a essas explicações" ("Uma longa corrida de revezamento", $O$ Estado de S. Paulo, caderno "Aliás", 12 de outubro de 2008, páginas J4 e J5, entrevista a Mônica Manir).

${ }^{314}$ Martin Buber, Eclipse de Deus - Considerações sobre a relação entre religião e filosofia, p. 7.
} 
perscrutada por uma razão equilibrada e aberta para o todo, o que constitui a autêntica postura da filosofia, desde suas origens ${ }^{315}$.

Com outras palavras, é isso o que declara Pieper num texto ${ }^{316}$ em que corrige esta agressiva sentença de Martin Heidegger: "Uma filosofia cristã é um círculo quadrado", ou seja, uma contradição em termos. Pieper inverte a rotunda afirmação de Heidegger e pergunta: Gibt es eine nicht-christliche Philosophie? (Existe uma filosofia não-cristã?), no sentido de que não pode haver uma voraussetzungslosigkeit, pois todo filosofar remete, de modo consciente ou inconsciente, a uma teologia pré-existente, a exemplo da já citada afirmação de Sartre - "não há essência do homem, porque não há Deus para concebê-la" -, que remete ao primeiro capítulo do Evangelho de João.

Para Pieper, a interpretação racionalista-secular do mundo - portanto, não cristã - não pode ser considerada uma "filosofia" do mesmo modo como esse conceito era entendido pelos fundadores da tradição ocidental de pensamento, como Platão e Aristóteles, por exemplo. Ao usar a palavra grega philosophía, nota Pieper, Platão se refere literalmente a um dito de Pitágoras, segundo o qual só Deus é sábio (sophós), enquanto o homem, na melhor das hipóteses, é somente alguém que busca amorosamente a filosofia, que ama o saber (um philo-sophós). A mesma ideia é transmitida por Sócrates, no Banquete, quando diz que nenhum dos deuses filosofa.

Nessa questão, o realista Aristóteles concorda com o idealista Platão, lembra Pieper. Para o Estagirita, à clássica pergunta filosófica - o que é isto? - corresponde uma resposta conhecida unicamente por Deus. "As questões verdadeiramente filosóficas (por exemplo: 'O que é o conhecer? 'O que ocorre, do ponto de vista da totalidade, quando morre um ser humano?"') impelem-nos a um confronto com o todo da realidade e da existência. Quem as formula vê-se, com efeito, obrigado a falar 'de Deus e do mundo', e isto é precisamente o que marca a diferença entre a filosofia e a ciência”, escreve Pieper, acrescentando que um médico não tem necessidade de falar "de Deus e do mundo" ao investigar a causa de uma doença, mas, no momento em que pergunta "o

\footnotetext{
${ }^{315}$ Perguntar pelo todo é uma característica que define o espírito humano, a filosofia e a universidade, nota Pieper. Platão afirma que "o espírito é de certo modo todas as coisas e deve travar relação com tudo o que existe (República 486c). Foi essa ideia que presidiu à fundação das primeiras universidades, como as de Paris, Bolonha e Oxford. Foi também o que filósofo e matemático britânico Alfred North Whitehead (1861-1947) expressou quando disse que a filosofia se ocupa da questão "What is it all about?", ou seja, indaga a respeito do todo, não de algo particular (conferir Josef Pieper, Abertura para o todo - A chance da universidade, tradução de Gilda Naécia Maciel de Barros e Jean Lauand, São Paulo, Apel, 1989).

316 Josef Pieper, "O caráter problemático de uma filosofia 'não-cristã”, tradução de Gabriele Greggersen e Jean Lauand (disponível em www.hottopos.com/mirand12/pieper.htm\#2).
} 
que é a doença em si?", necessariamente precisa refletir sobre a natureza humana em relação à realidade como um todo.

Outro exemplo citado por Pieper: no diálogo Menon, de Platão, quando se torna evidente que não é mais possível avançar no caminho da argumentação racional, Sócrates afirma que a partir desse momento é necessário apoiar-se naqueles "que são sábios nas coisas divinas". Mais uma vez, destaca Pieper, Sócrates se volta para um dado proveniente de fonte sobre-humana, cuja interpretação pode ser chamada de teologia. Por fim, a metafísica fria e crítica de Aristóteles não exclui essa fonte, afirma Pieper, lembrando que a fundamental análise de Werner Jaeger sobre o tema mostrou que a doutrina aristotélica do ser está, em última análise, determinada pelo pressuposto anterior de uma fé que transcende o pensamento. "Enquanto, pois, não se entenda por filosofia algo inteiramente diverso do que significava o conceito em sua primeira definição no Ocidente, permanecerá implícita e inerente à filosofia a exigência de um dado anterior, suprarracional", resume Pieper.

Com isso, Pieper não apenas questiona a possibilidade de que uma interpretação puramente racionalista da existência seja chamada de filosofia. Ele também considera difícil uma filosofia não ser chamada de "cristã", porque tudo o que, na concepção de mundo platônica, é chamado de "sabedoria dos antigos" e "conhecimento das coisas divinas", por exemplo, "encontra-se preservado (ainda que depurado, elevado e, ao mesmo tempo, infinitamente ultrapassado) na mensagem anunciada pelo Logos divino".

Pieper ainda acrescenta que seria impossível uma filosofia sem nenhum elemento de teologia. Mesmo Descartes, ao responder à questão central da dúvida metódica - "Como podemos ter certeza de não estar apenas sonhando?" -, apela para a veracidade de Deus, que não poderia, de forma nenhuma, nos enganar. "Ou seja, Descartes apóia-se explicitamente na própria tradição da fé, que, no entanto, pretendia excluir por princípio." Kant - diz Pieper -, no seu ensaio sobre a religião, em que cita a Bíblia mais de setenta vezes, não permanece “dentro dos limites da razão pura”, como anuncia no título da obra. "Evidentemente, não podemos só por isso falar numa 'filosofia cristã'. Contudo, é igualmente evidente que não se pode considerar esse tratado como totalmente 'não-cristão'."

Finalmente, na área da educação, o pensamento negativo de Tomás de Aquino tem muitas contribuições a dar à pedagogia contemporânea. Esta, como um reflexo do racionalismo exacerbado, encontra-se fundada no conhecimento lógico-científico do mundo e na busca de certezas - ou seja, na ciência mais profunda possível do objeto de 
estudo, seja uma substância química, um acidente geográfico, uma característica linguística ou um fato histórico. Isso traz consequências também para a avaliação dos alunos, feita de maneira rigorosamente lógica, como se a formação humana pudesse ser medida por números ${ }^{317}$.

As escolas de ensino médio, que buscam preparar os alunos para o vestibular, são a expressão mais acabada da educação exageradamente racionalista em vigor hoje. Nelas, os estudantes são submetidos a um processo mecânico de aprendizagem, em que o importante é dominar intelectualmente os conteúdos ministrados. Quanto mais dados apreendidos racionalmente e acumulados no intelecto - dados que corresponderiam fielmente à realidade dos objetos e dos conceitos -, mais preparado o indivíduo está para o exame de admissão na universidade.

Também para essa educação moldada pelo racionalismo radical, o pensamento negativo de Tomás de Aquino representa um poderoso "antídoto". Diante da negatividade, Tomás lembra que não é possível atingir a mais profunda essência das coisas - o que já pode ajudar o educador a desprezar a ilusória e desgastante obrigação de apreender e ensinar as realidades últimas de sua disciplina ${ }^{318}$.

Mas há outras revelações proporcionadas pela negatividade, ainda mais instigantes. Como afirma Lauand ${ }^{319}$, o caráter de mistério do mundo leva o homem a desenvolver uma humildade antirracionalista e um senso de humor que pode conduzi-lo ao conhecimento mais profundo das coisas criadas. "O riso pressupõe o reconhecimento e aceitação da condição de criatura, de que o homem não é Deus, do mistério do ser, da

\footnotetext{
317 Por exemplo, numa das mais importantes instituições de ensino do Brasil, o Instituto Presbiteriano Mackenzie, em São Paulo, a média dos alunos da disciplina de Química do ensino médio, na segunda etapa de 2008, foi definida por esta fórmula: (( (nota A x $2+\operatorname{nota} \mathrm{B} \times 3+\operatorname{nota} \mathrm{C} \times 5) / 10$ x 9) + (nota do simulado $\mathrm{x}$ 1)) / 10 + nota de participação). Isso se deu em todas as disciplinas, e não somente às ligadas às ciências exatas. Em História, a fórmula era um pouco mais simples: (( (nota $\mathrm{A} \times 1+$ nota $\mathrm{B} \times 1+$ nota $\mathrm{C} \times 1+$ nota $\mathrm{D} \times 1) / 3 \times 9)+($ nota do simulado x 1)) / 10 + nota de participação). Há vários anos, essa é a maneira como os alunos daquele colégio são avaliados - através de complicadas fórmulas matemáticas. Trata-se de um dos exemplos mais evidentes da influência - e dos estragos - do racionalismo exacerbado na educação.

${ }^{318}$ Em contraste, os antigos tinham seu próprio modo de ver o conhecimento: para eles, a realidade e o homem são tais que não se pode pretender a clareza da ciência a não ser que se trate de assuntos de menor importância. Em Tomás encontra-se esta afirmação: "O pouco que se pode obter no conhecimento das realidades elevadíssimas é muito mais importante do que o conhecimento claríssimo que se tem das coisas menores" 318 . A dignidade de um conhecimento não advém da clareza, mas do objeto. E, em filosofia, os objetos não devem ser analisados de um ponto de vista limitado como nas ciências (daí lhes advém a clareza), mas pergunta-se pela totalidade. E dessa forma fomos conduzidos a uma súbita inversão do cientificismo: só podemos ter precisão e clareza e expressar protocolar ou numericamente realidades de menor importância. Já o pouco conhecimento que podemos ter na filosofia é sumamente importante.

${ }^{319}$ Jean Lauand, "Deus ludens - O lúdico no pensamento de Tomás de Aquino e na pedagogia medieval", em Filosofia, linguagem, arte e educação, páginas 15-37.
} 
não pretensão de ter o mundo absoluta e ferreamente compreendido e dominado pela razão humana."320

Ocorre que esse bom humor encontra-se nos fundamentos da realidade, afirma Lauand, citando a interpretação que Tomás de Aquino faz dos seguintes textos extraídos dos livros de Provérbios e do Eclesiástico:

Com Ele estava eu, compondo tudo, e eu me deleitava em cada um dos dias, brincando diante dele o tempo todo, brincando no orbe da terra e as minhas delícias são estar com os filhos dos homens. ${ }^{321}$

Corre para tua casa, e lá recolhe-te e brinca e realiza tuas concepções. ${ }^{322}$

Do versículo de Provérbios, Tomás - no livro I do seu Comentário às sentenças - extrai a ideia de que o ato de Criação está permeado pelo lúdico, pelo brincar de Deus. No início do mundo, a Sabedoria - identificada com Cristo, que é o Logos, o Verbo, o Princípio da Criação, como afirma o Evangelho de João $o^{323}$ - estava com Deus, brincando e compondo as coisas. "A sabedoria de Deus cria brincando, pois é próprio da sabedoria o ócio da contemplação, tal como se dá nas atividades do brincar, que não se buscam por um fim que lhes é extrínseco, mas pelo prazer que dão por si mesmas", diz Lauand $^{324}$.

Já no versículo registrado no Eclesiástico, Tomás vê um convite ao homem para que exerça seu conhecimento seguindo os padrões lúdicos de Deus e um programa pedagógico que aponta para o fim por excelência da educação: a contemplatio, segundo Lauand $^{325}$. No prólogo do Comentário ao De hebdomadibus, o Aquinate interpreta o imperativo "corre para tua casa, e lá recolhe-te" como um convite ao recolhimento, ao entrar em si mesmo, afastando-se de tudo que possa desviar o homem da sabedoria. Dessa forma, ele pode "brincar e realizar as suas concepções", através das quais contempla a verdade.

\footnotetext{
${ }^{320}$ Jean Lauand, obra citada, p. 16.

${ }^{321}$ Provérbios 8:30-31. Tradução de Jean Lauand a partir da versão latina utilizada por Tomás de Aquino: "Cume o eram cuncta componens ET delectabar per singulos dies ludens coram eo omni tempore, ludens in orbe terrarum et deliciae meae esse cum filiis hominum".

322 Eclesiástico 32:15-16. Tradução de Jean Lauand a partir da versão latina utilizada por Tomás de Aquino: "Praecurre prior in domum tuam, et illuc advocare et illic lude, et age conceptiones tuas".

${ }^{323}$ João 1:1: "No princípio era o Logos e o Logos estava diante de Deus, e o Logos era Deus".

${ }^{324}$ Jean Lauand, obra citada, página 31. O caráter de criatura, de design de Deus - como exposto no início deste capítulo - é o que torna as coisas cognoscíveis ao intelecto humano. Por isso, assim como é possível conhecer algo da estrutura interna das coisas, pode-se também tentar captar o senso lúdico do Verbum ao criar cada ser, propõe Lauand. Para ele, a água de coco, um precioso isotônico encapsulado num revestimento colocado no alto de uma árvore, e a girafa, com seu grande pescoço e jeito desengonçado, são sinais claros do bom humor do Criador ao projetar o mundo.

325 Jean Lauand, obra citada, página 33.
} 
Tomás não diz como se dá esse "lude et age conceptiones tuas" (brinca e realiza tuas descobertas); seja como for, trata-se de um convite ao homem com sua limitada inteligência - a entrar no jogo do Verbum (na Suma I, 37, 1, diz que verbum é vocábulo ad significandum processum intellectualis conceptionis, "para significar o processo intelectual de concepção"), a descobrir suas peças, seu sentido: a "lógica lúdica" do Logos ludens. Certamente, trata-se da contemplação da sabedoria (o que inclui a contemplação "terrena", da maravilha da criação), mas nada impede que estendamos esse convite ao exercício racional-lúdico a outros campos: num tempo como o nosso, em que alguns antevêem o fim da sociedade do trabalho, o fim da burocracia, o fim da racionalidade sem imaginação, Domenico de Masi, o profeta da sociedade do lazer - não por acaso napolitano; Tomás também era da região de Nápoles - nos vem anunciar "a importância do espírito lúdico, sem o qual não se constrói a ciência" ${ }^{326}$

O homem medieval, moldado pelo cristianismo, percebe essa realidade, e por isso tem uma relação com o mundo muito mais lúdica do que o homem moderno, que, ao longo dos séculos, foi se distanciando cada vez mais do brincar, envolvido por sucessivas camadas de racionalismo. Não à toa, os maiores educadores medievais ensinavam brincando. Lauand cita uma carta de Alcuíno (735-804) ao imperador Carlos Magno, em que afirma: "Deve-se ensinar divertindo"327. Petrus Alfonsus (1062-1110) usa anedotas para a formação do clero e dos intelectuais. Em sua obra Disciplina clericalis, por exemplo, para ensinar os eruditos e futuros padres sobre o caráter efêmero e ilusório das riquezas, ele conta a seguinte anedota:

\begin{abstract}
Um pastor sonhou que tinha mil ovelhas. Um mercador quis comprá-las para revendê-las com lucro e queria pagar duas moedas de ouro por cabeça. Mas o pastor queria duas moedas de ouro e uma de prata por cabeça. Enquanto discutiam o preço, o sonho foi se desvanecendo. E o vendedor, dando-se conta de que tudo não passava de um sonho, mantendo os olhos ainda fechados, gritou: "Uma moeda de ouro por cabeça e você leva todas". 328
\end{abstract}

Essa dimensão lúdica do educar perdeu-se hoje. Ignorando a ideia de que o brincar dá acesso às realidades mais profundas, a racionalista educação contemporânea prioriza um ensino baseado no acúmulo de informações, em prejuízo da alegria do aprender.

Note-se que isso ocorre até mesmo nas escolas de tradição católica, que têm justamente Tomás de Aquino como seu inspirador, desde que o papa Leão XIII promulgou, em 1879, a encíclica Aeterni Patris, estimulando a educação fundada na filosofia do Aquinate. É mais uma demonstração de que o autor da Suma teológica foi mal interpretado: jamais uma pedagogia inspirada no legítimo pensamento de Tomás -

\footnotetext{
${ }^{326}$ Jean Lauand, obra citada, página 35.

327 Jean Lauand, obra citada, página 19.

${ }^{328}$ Petrus Alphonsus, Disciplina clericalis, em Cultura e educação na Idade Média, organização de Jean Lauand, Martins Fontes, 1998, páginas 249-250.
} 
profundamente marcado pela negatividade - poderia resultar em metodologias racionalistas como as praticadas nas instituições de ensino católicas atuais. Antes, produziria uma educação mais lúdica, atraente e eficiente, que ainda está para ser desenvolvida.

Bem diferente do que sugere o "tomismo" tradicional é a visão de Tomás de Aquino que surge quando se considera o elemento negativo do seu pensamento. Como foi mostrado neste capítulo, a negatividade elimina qualquer traço de racionalismo na obra do Aquinate. Isso altera de modo drástico a forma de ver a existência humana, a teologia, a filosofia e a educação: o homem fica sabendo que não dispõe de certezas absolutas para se conduzir no dia a dia, e por isso precisa fazer uso da virtude da prudência; os teólogos e religiosos são chamados a ver o cristianismo como uma religião não de regras a serem cumpridas, mas de estímulo à liberdade e à autonomia individual; aos filósofos é feito o convite para especular sobre o que está acima da razão e, assim, chegar ao conhecimento, ainda que parcial, do princípio de todas as coisas; e aos educadores, finalmente, é dada a oportunidade de refletir sobre um ensino que priorize o lúdico, fonte do entendimento da realidade mais profunda. É tudo isso que o pensamento negativo de Tomás de Aquino ensina ao homem contemporâneo. 


\section{O CONCEITO TOMASIANO DE PARTICIPAÇÃO}

O conceito de participação - expresso pela palavra grega $\mu \Upsilon \psi \varepsilon \varphi \iota \omega$ (métheksis) - foi introduzido na filosofia por Platão (427-347 a.C. $)^{329}$. Com ele, o pensador grego buscou explicar as relações entre as coisas do mundo sensível, que se encontram em constante mudança, e as Ideias ou Formas eternas e imutáveis localizadas no lugar inteligível $^{330}$. Para Platão, os seres sensíveis não têm propriamente realidade, mas dependem da sua Ideia correspondente, que lhes dá o ser por participação. Uma árvore, por exemplo, é uma mera cópia, uma imagem da Ideia real de árvore, assim como um homem, um cachorro e uma pedra não são reais por si, mas participam da Ideia de homem, cachorro e pedra, respectivamente.

No diálogo Fédon, o Sócrates platônico está a procurar a causa dos seres. Recusando-se a admitir, como os filósofos naturalistas, que a origem de todas as coisas encontra-se no mundo material, Sócrates reflete que deve "buscar refúgio nas ideias e procurar nelas a verdade das coisas",331, e faz a seguinte afirmação: "Suponho que há um

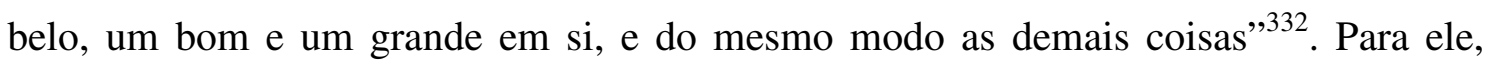
"quando, além do belo em si, existe um outro belo, este é belo porque participa daquele, apenas por isso e por nenhuma outra causa",333.

No mesmo diálogo, Sócrates enfatiza:

Quanto a mim, estou firmemente convencido, de um modo simples e natural, e talvez até ingênuo, que o que faz belo um objeto é a existência daquele belo em si, de qualquer modo que se faça a sua comunicação com este. O modo por que essa participação se efetua, não o examino neste momento; afirmo, apenas, que tudo o que é belo é belo em virtude do Belo em si. ${ }^{334}$

\footnotetext{
329 Aristóteles afirma que Platão apenas mudou o nome do conceito então já usado pelos filósofos pitagóricos, que chamavam de "imitação dos números" o que os platônicos viriam a denominar "participação" nas Ideias (Metafísica I, VI).

${ }^{330}$ A famosa expressão "mundo das Ideias" platônico - que dá a entender tratar-se de um universo separado, onde se encontrariam as Ideias eternas e imutáveis - é resultado de um erro de tradução cometido na época helenística e reproduzido nos séculos seguintes. No texto grego original de $A$ república (509d), a palavra usada por Platão é tópos (lugar) e não kósmos (mundo). Assim, as Ideias ou Formas, que podem ser alcançadas pela intelecção, estão no pensamento, e não num mundo físico separado.

${ }^{331}$ Platão, Fédon 99e (tradução de Jorge Paleikat e João Cruz Costa).

${ }^{332}$ Fédon 100b.

${ }^{333}$ Fédon 100c.

${ }^{334}$ Fédon 100d.
} 
Entre as Ideias eternas, a que exerce um papel preponderante é a Ideia do Bem. É por ela que as coisas do mundo sensível existem, têm uma essência e podem ser conhecidas, como se lê na República de Platão:

Logo, para os objetos do conhecimento, dirás que não só a possibilidade de serem conhecidos lhes é proporcionada pelo bem, como também é por ele que o Ser e a essência lhes são adicionados, apesar de o bem não ser uma essência, mas estar acima e para além da essência, pela sua dignidade e poder. $^{335}$

A Ideia, para Platão, é não somente um princípio de inteligibilidade, mas também um princípio de existência, nota Simone Manon ${ }^{336}$. "É por ela que as coisas sensíveis podem ser o que são." 337

Reconhecendo o caráter obscuro da participação dos seres na sua Ideia correspondente, S. Manon destaca que a participação é às vezes definida como imitação. A Ideia é o modelo eterno, imutável, o paradigma que a coisa sensível imita de maneira mais ou menos semelhante, diz a autora.

Ainda que sejam meras cópias da realidade perfeita das Ideias, as coisas do mundo sensível derivam delas e revelam algo delas. "As imagens são tanto o que nos distancia como o que nos reconduz àquilo de que elas são a manifestação”, acrescenta a autora. "Elas nos desviam do real na qualidade de simulacros, mas podem despertar em nós a sua lembrança na qualidade de imagens-retrato.”,338

Há em Platão uma mística da Ideia, em nome da qual ele se impõe como um desprezador do sensível. Mas ele afirma, por outro lado, que a imagem é um signo, a aparência, uma aparição, um misto de ser e não-ser e, como tal, uma mediação. Platão jamais foi até o fim da tendência que o conduzia a anular o grau ontológico do sensível. Mesmo a sombra mais vaporosa é a sombra de algo. O sensível é assim salvo na medida em que manifesta aquilo de que procede, ou seja, aquilo que lhe confere sentido e realidade: o inteligível. ${ }^{339}$

Por isso, aponta a autora, a participação é também definida como uma presença da Ideia na coisa. Isso fica claro num outro trecho do Fédon:

Em consequência, jamais estariam de acordo com quem te viesse dizer que um é maior do que outro pela cabeça, e que o menor é menor pelo mesmo motivo; mas continuarias firmemente a afirmar que tudo aquilo que é maior do que outro não o é por nenhuma outra causa senão pela Grandeza; e que o que é menor não o é por nenhuma outra causa senão pela Pequenez. ${ }^{340}$

\footnotetext{
${ }^{335}$ Platão, República 509b (tradução de Maria Helena da Rocha Pereira).

${ }^{336}$ Simone Manon, Platão, tradução de Flávia Cristina de Souza Nascimento, São Paulo, Martins Fontes, 1992.

${ }^{337}$ Simone Manon, obra citada, página 93.

338 Simone Manon, obra citada, página 94.

${ }^{339}$ Simone Manon, obra citada, página 94.

${ }^{340}$ Platão, Fédon 101a.
} 
Esse pensamento idealista de Platão foi criticado pelo filósofo grego Aristóteles (384-322 a.C.), que explica a existência do mundo sensível de maneira bem diferente da noção de participação platônica. Em sua Metafísica, o Estagirita estabelece as quatro "causas e princípios primeiros" que condicionam o ser: a causa formal, a causa material, a causa eficiente e a causa final. As duas primeiras se referem à forma e à matéria, que estruturam todas as coisas sensíveis. A causa eficiente é aquilo de que provêm a mudança e o movimento das coisas. Já a causa final diz respeito ao propósito, à finalidade dos seres. ${ }^{341}$

Aristóteles distingue quatro formas de significado do ser. Segundo ele, o ser pode ser conhecido "por acidente", "por si mesmo", "como verdadeiro e como falso" e "em potência ou em ato" 342 . Entre essas quatro grandes distinções, Aristóteles desconsidera o ser "por acidente" - que se refere apenas a um atributo da coisa, como quando se diz "Sócrates é músico", mas não à coisa em si - e o ser "como verdadeiro e como falso", que revela somente a veracidade ou não do objeto. O mais profundo sentido do ser, diz Aristóteles, reside nos dois outros tipos de significado - o ser "por si mesmo" e "em potência ou em ato".

Conhece-se o ser "por si mesmo" através de dez "categorias", como diz Aristóteles, que são: substância, qualidade, quantidade, relação, ação, paixão, lugar, tempo, situação e posse. Dessas, a mais importante é a primeira. Substância - que traduz a palavra grega $\circ \sigma \Leftrightarrow \alpha$ (ousía) - é o fundamento primeiro das coisas, de que tudo o mais decorre. Para Aristóteles, nenhuma das outras categorias existe por si e "separadamente" da substância e só a substância é "separada", autônoma, independente das outras.

O que é primariamente, isto é, não em sentido determinado, mas sem determinações, deve ser a substância. ${ }^{343}$

Substância parece se confundir com matéria, mas ambas se distinguem porque, enquanto a substância possui determinações - o que a faz ser uma coisa e não outra -, a matéria é desprovida delas. Matéria sem substância não passa de um ser sem significado, sem determinações. Pode-se dizer que substância possui matéria, mas não somente ela. É preciso algo mais para dar conta desse conceito. Esse algo é a forma.

\footnotetext{
${ }^{341}$ Aristóteles, Metafísica I.

${ }^{342}$ Metafísica V, 7.

${ }^{343}$ Metafísica VII, 1.
} 
A forma - definida por Aristóteles como "a essência de cada coisa e a sua substância primária"344 - pode ser entendida como a substância desprovida de matéria. É ela que faz da substância aquilo que ela é e dá à matéria as suas determinações. Matéria e forma, porém, são separadas apenas no pensamento. Na realidade do mundo, estão sempre unidas. É inconcebível, para Aristóteles, haver matéria sem forma e viceversa. Separadas, cada uma perde o estatuto de substância. Enfim, substância é um composto de forma e matéria.

Graças a esse composto é que se pode conceber o ser "em potência ou em ato". "Em potência" se refere à matéria indeterminada, pronta a ser passivamente determinada pela forma. "Em ato" significa a ação da forma sobre a matéria. Como ocorre quando se constrói uma casa, exemplifica Aristóteles: os tijolos e pedras representam a casa "em potencial", a matéria, que passam a ser uma casa quando sofrem a ação da forma. Assim, enquanto a matéria sofre deteriorações, a forma é eterna, pois a forma que dá determinações à matéria para a formação do homem, por exemplo, nunca mudará: o homem, mesmo sendo mortal, sempre será um animal bípede.

Com essas ideias, Aristóteles mostrou que o conhecimento do ser está mesmo nas coisas sensíveis da natureza - e não nas alturas quase inalcançáveis do inteligível. É ali, na estrutura interna das coisas, na sua matéria e na sua forma, que se encontram as respostas sobre o que é o ser, qual é a sua forma e qual é a sua finalidade.

Mais tarde, os conceitos de participação, originário de Platão, e de substância, tomado de Aristóteles, foram utilizados por Boécio (480-525) para discutir a questão do Bem, como mostra Rudi A. te Velde, no seu excelente livro Participation and substantiality in Thomas Aquinas ${ }^{345}$. No tratado De hebdomadibus, Boécio faz a seguinte pergunta: tendo como pressuposto que todas as coisas existentes são boas em si mesmas - uma vez que todas buscam o bem, o que seria impossível se não fossem boas -, elas são boas por participação ou por substância? Se as criaturas fossem boas em razão de sua substância, elas seriam idênticas ao primeiro Bem, ou seja, Deus, e então o mundo estaria habitado por uma infinidade de deuses, o que evidentemente não é verdade. Já se as coisas fossem boas por participação, ocorreria que elas não seriam boas por si mesmas, como está pressuposto, mas receberiam essa qualidade de algo externo a elas.

\footnotetext{
${ }^{344}$ Metafísica VII, 7.

${ }^{345}$ Leiden: E. J. Brill, 1995. Parte deste capítulo está baseada nessa obra.
} 
Boécio propõe uma solução para essa questão. Para o autor do De hebdomadibus, não pode haver identidade entre o ser substancial de algo e o fato de ser bom. As coisas podem ser boas, mas sua bondade não é a mesma coisa que o seu ser. Ser bom é acidental, assim como ser branco, redondo ou qualquer outra propriedade da substância. Mas, na medida em que as coisas vêm do primeiro Bem, a elas deve ser atribuído um certo bem. Assim, o ser substancial é bom não em virtude de sua essência, mas em virtude da relação com o primeiro Bem. "Somente Deus é bom em virtude da sua essência. Todas as criaturas são boas, mas não em razão de sua essência, uma vez que em nenhum ser a essência consiste no bem em si, mas consiste em algo mais, por exemplo, humanidade ou algo semelhante. $\mathrm{O}$ ser das coisas criadas pode ser chamado bem por causa da sua relação com o primeiro Bem como sua causa."

Essa solução proposta no De hebdomadibus é menos importante do que as consequências da pergunta feita por Boécio. Foi a partir dela que Tomás de Aquino começou a elaborar com mais profundidade a doutrina da participação dos seres em Deus, sempre no contexto da criação ${ }^{347}$. Velde destaca que o uso do termo "participação" se faz paulatinamente mais frequente na obra do Aquinate e vem a ocupar, nos textos tardios - entre eles, a Suma teológica -, um lugar mais importante do que nos primeiros tratados, como $O$ ente e a essência e o Comentário às Sentenças.

Ao mesmo tempo, o conceito de participação dos seres - continua Velde - ganha mais peso filosófico gradualmente e recebe sua formulação final passo a passo. Por exemplo, na questão disputada Sobre a Verdade, ele não possui um papel significativo, aparecendo apenas na questão 21. Já na Suma teológica, a noção de participação é usada de modo tecnicamente consistente e num sentido sistematicamente bem-elaborado, referindo-se à derivação dos seres a partir da primeira causa. Embora Tomás conceba a criação em termos de participação desde o início de sua carreira de professor e pensador, esse conceito atingiu, mais tarde, uma maturidade e precisão que não se encontram em suas obras de juventude. Para Velde, se os únicos textos disponíveis de Tomás hoje fossem $O$ ente e a essência, o Comentário às Sentenças e De veritate, a

\footnotetext{
${ }^{346}$ Rudi A. te Velde, obra citada, p. 18-19.

347 Raeymaker observa: "A ideia de participação ocorre de maneira apenas esporádica nas obras de S. Tomás. O De hebdomadibus fornece ao Doutor Angélico a ocasião de uma reflexão sistemática sobre a participação e sobre sua aplicação ao ser (...). A partir daí, essa doutrina da participação se torna mais e mais fundamental na metafísica do Aquinate" (De Raeymaker, "L'être selon Avicenna et selon S. Thomas d'Aquin", em Avicenna Commemoration Volume, Calcutta, 1954, p. 128-129, citado por Rudi A. te Velde, obra citada, p. 5).
} 
noção de participação não poderia ser considerada de suprema importância para seu pensamento.

Como foi dito, o início dessa reflexão mais profunda de Tomás sobre a participação se verifica no Comentário ao De hebdomadibus de Boécio e na questão 21 de De Veritate - a chamada "questão do Bem" -, compostos na mesma época, entre 1256 e 1259, que corresponde ao primeiro período do magistério de Tomás na Universidade de Paris.

Em De Veritate, por exemplo, ao falar sobre a bondade essencial dos seres, Tomás afirma que há uma diferença entre a bondade de Deus e a bondade das criaturas. A bondade essencial não se encontra em algo quando se considera a sua natureza, mas apenas na medida em que esse algo tem ser. Ou seja, a bondade essencial encontra seu fundamento formal no ser de uma essência. A essência de Deus é idêntica ao seu ser. Ele é "puro ser" auto-subsistente, não recebido numa essência distinta. Em cada criatura, porém, a essência difere do ser: ela não é seu ser, mas recebe ser de algo externo a ela (esse participans ab alio). O que é criado tem ser participado (esse participatum). Esta é a razão por que a criatura é boa por participação: ela é boa por participação porque tem ser por participação.

Como explica Velde:

Tomás busca uma bondade com respeito à substância que é mais do que
meramente uma (extrínseca) relação com o primeiro bem, uma bondade
substancial que é, entretanto, per participationem. A resposta é "participação
do ser": algo é bom como uma substância e como um ser precisamente
porque e na medida em que, como substância, tem ser por participação.
Tomás reconcilia a oposição em Boécio entre substância e participação ao
estender a participação ao ser (esse) da substância. Assim, ele vai além do
caráter acidental de participação e da equação de participação com
"acidentalmente".

Depois das considerações iniciais feitas em De Veritate e no Comentário ao De hebdomadibus, Tomás desenvolve e refina o conceito de participação em obras posteriores, como o Comentário aos Nomes Divinos do Pseudo Dionísio Areopagita e a Suma teológica. Como se verá, Tomás não dirá mais - como faz nas primeiras obras em que cita o tema - que cada coisa participa seu próprio ser (e sim que cada coisa tem ser como resultado da participação no ser) nem que, estritamente falando, uma coisa participa no ser divino (mas sim na semelhança do ser divino) ${ }^{349}$.

\footnotetext{
${ }^{348}$ R. A. te Velde, obra citada, p. 29.

${ }^{349}$ R. A. te Velde, obra citada, p. 5, nota 5.
} 
Também nesse aspecto, Tomás de Aquino recebe profunda influência do Pseudo Dionísio Areopagita, que muito antes do Aquinate uniu a teoria das Ideias do mestre da Academia - na forma como foi transmitida pelo neoplatonismo - e a noção de matéria e forma do Estagirita, a fim de elaborar uma visão cristã sobre a existência das coisas. Dionísio contribui decisivamente para Tomás de Aquino refletir sobre a questão da participação, de modo que o pensamento mais profundo do Aquinate sobre esse tema tem como base a obra daquele pensador.

Em Dos nomes divinos - tratado escrito com o propósito deliberado de celebrar o processo pelo qual a fonte de toda essência "dá ser a todo ser" ${ }^{350}$-, Dionísio se refere a Deus como "o que é" 351 , numa referência explícita ao termo com que Deus é designado no livro bíblico do Exxodo (3:14).

No capítulo 5, o autor propõe uma série de definições da divindade que apontam para a ideia de que Deus é “o ser em si” que dá o ser, que transfere o ser às coisas. Estas vêm à existência graças a essa doação, a essa "transferência" de ser, responsável pela presença dos seres no mundo, sem a qual nada existiria. Deus é o que "existe por si", 352 , o "ser dos seres",353, e seu primeiro atributo é o ser"

Como afirma Dionísio, referindo-se a Deus:

É o ser em que se apóiam o tempo e a eternidade que abraça os seres. O ser de tudo o que de algum modo é. Vir a ser de tudo quanto sucede. Daquele que é vêm a eternidade, essência, ser, tempo, vir a ser e efeitos do vir a ser. É aquele que é e o que a tudo sustenta, o que de algum modo existe e o que por si existe. ${ }^{35}$

Não está contido no ser, mas sim ele contém o ser. Ele é a eternidade do ser, origem e medida do ser. Ele é anterior à essência, à existência e à eternidade. Ele é fonte criadora, o meio e o fim de todas as coisas. ${ }^{356}$

Essa mesma concepção encontra-se em Tomás de Aquino. Na Suma teológica ${ }^{357}$, Tomás afirma que o nome mais próprio para designar Deus é "Aquele que é”. E isso por três razões: porque essa expressão não designa uma forma, mas o próprio ser; porque ela não determina nenhum modo de ser - como convém a Deus, que é sem

\footnotetext{
${ }^{350}$ Dos nomes divinos $\mathrm{V}, 1$.

${ }^{351}$ Dos nomes divinos $\mathrm{V}$.

352 Dos nomes divinos $\mathrm{V}$.

${ }^{353}$ Dos nomes divinos $\mathrm{V}$.

${ }^{354}$ Dos nomes divinos $\mathrm{V}$.

${ }^{355}$ Dos nomes divinos $\mathrm{V}$.

${ }^{356}$ Dos nomes divinos V.

${ }^{357}$ Suma teológica q. 13, a. 11.
} 
determinação em todos os modos -; e, finalmente, porque ela significa ser no presente, próprio de Deus, cujo ser não conhece nem passado nem futuro. Diz Tomás:

\begin{abstract}
Não é necessário que todos os nomes divinos impliquem uma referência às criaturas; basta que sejam tomados de perfeições comunicadas por Deus às criaturas. Entre estas, a primeira de todas é o próprio ser, de onde se tomou o nome Aquele que é..$^{358}$
\end{abstract}

Assim, participar, para Tomás, indica um "ter com”, um “co-ter" ou um "ter" em oposição a "ser", um "ter" pela dependência (participação) com outro que "é”, afirma Jean Lauand ${ }^{359}$. Um exemplo simples facilita a compreensão desse conceito tão importante: diz-se que um ferro em brasa tem calor porque participa do fogo, que "é calor" ${ }^{, 360}$, e um objeto iluminado "tem luz" porque participa da fonte luminosa, que "é luz". Afastem-se o ferro do fogo e o objeto da fonte de luz e eles deixam de ser quente ou luminoso, respectivamente. Para Tomás, da mesma forma como um objeto é iluminado graças à sua participação na fonte de luz, também as coisas possuem ser, têm ser, exercem o ato de ser, porque participam da fonte de ser, participam daquele que é o ser, Deus. E é exatamente nisso que consiste a participação. Trata-se da mesma ideia de $\mu \Upsilon \psi \varepsilon \varphi ı \omega$ platônica, mas acrescida de noções aristotélicas e revestida de um sentido cristão. Em Tomás, essa noção recebe um tratamento originalíssimo e se encontra na base de dois conceitos fundamentais na obra do Aquinate: a criação, que se refere ao mundo natural, e a graça, relacionada à natureza divina do cristão.

É interessante notar, antes de tudo, uma diferença entre a concepção dionisiana e o pensamento de Tomás a respeito do ser, como já foi citado neste trabalho ${ }^{361}$. Para Dionísio, Deus está acima do Ser. Nem pode ser nomeado Ser. Já para Tomás, Deus é o Ser acima dos seres, um Ser concebível. Quando fala que Deus é o Ser, Dionísio está no campo da teologia simbólica e da teologia conceitual. Quando passa para a teologia negativa, ele nega que Deus é o ser e atinge a máxima transcendência. Já Tomás, com o seu característico apego à realidade concreta, torna a ideia de Deus mais próximo ao considerá-lo o Ser no mais alto grau ontológico.

Fundamentalmente, é o conceito de participação que se aplica à criação do mundo - tanto quanto é possível à razão humana saber sobre esse tema inesgotável -, segundo Tomás. Todas as coisas existem e se mantêm graças à participação no ser em

\footnotetext{
358 Idem.

359 Tomás de Aquino, Verdade e conhecimento. São Paulo, Martins Fontes, 1999, p. 56.

360 Esse exemplo, independentemente do que afirme a física atual, é útil ao leitor comum para a compreensão do conceito de participação em Tomás de Aquino, salienta Lauand.

${ }^{361}$ Cf. o capítulo 4, "Tomás leitor de Dionísio".
} 
si. Nada existe que não dependa dele, que não participe dele. Isso está claro na obra do Aquinate:

E assim como depende da vontade de Deus que as coisas sejam criadas, assim também dessa vontade depende que sejam conservadas no ser. Com efeito, Deus as conserva no ser dando-lhes o ser continuamente, a tal ponto que, se Ele lhes subtraísse sua ação, como observa Agostinho, todas as criaturas seriam reduzidas ao nada. Assim, como dependia do poder do Criador a existência das coisas, antes que elas existissem, também depende de seu poder, quando já existem, que deixem de existir. ${ }^{362}$

Como não poderia deixar de ser, também nesse aspecto Tomás de Aquino é devedor do Pseudo Dionísio Areopagita, que igualmente enfatiza a dependência de todas as coisas em relação ao Ser. Dionísio afirma, por exemplo:

Todo ser e todas as idades derivam sua existência daquele Ser que foi anterior a todos. Dele procedem toda eternidade e tempo. Ele é anterior ao princípio e causa de toda a eternidade, do tempo e de todas as coisas. Todas participam dele e Ele nada abandona. "Ele é antes que tudo e tudo subsiste nele." Em resumo, anterior a tudo quanto existe, nele tudo tem seu fundamento e se conserva. ${ }^{363}$

A vida enquanto tal é o princípio de todo ser vivente. A Semelhança de tudo que é semelhante, a Unidade do unido, a Ordem do ordenado. E assim tudo o mais. Verás que todas as demais coisas participam de uma ou outra qualidade ou de muitas. O que elas têm primariamente é a existência, a qual lhes assegura de sua permanência e de que são fundamento de tal ou qual coisa. Existem somente por participação no Ser. Com muito mais razão, pois, participam do Ser as coisas que existem graças a essas participações. ${ }^{364}$

Como algo que é dado, transferido por Deus, o ser constitui o ato mais fundamental e radical, destaca Lauand, interpretando o pensamento de Tomás de Aquino. "O ser não é uma atividade a mais que deriva da natureza de cada coisa. O ser no sentido de ser-real - está fora e acima da série de características que compõem a essência." 365

O ato de ser é anterior a tudo, como afirma Tomás de Aquino:

O ser é aquilo que há de mais íntimo em cada coisa, e o que mais profundamente está inserido em todos os entes ${ }^{366}$

Por tudo isso, o ser não pode ser definido. Anterior a qualquer ideia, não é passível de ser transformado num conceito. Pode-se apenas concebê-lo como atividade, como ato. "Todas as coisas, todos os entes, são, antes de mais nada, aqueles que

\footnotetext{
${ }^{362}$ Suma teológica, questão 9, artigo 2.

${ }^{363}$ Dos nomes divinos $\mathrm{V}$.

${ }^{364}$ Dos nomes divinos V.

${ }^{365}$ Jean Lauand, obra citada, página 61.

${ }^{366}$ Suma teológica I, 8, 1.
} 
'exercem o ato' de ser”, diz Lauand ${ }^{367}$, recorrendo, mais uma vez, à linguagem comum: se o presidente é aquele que exerce o ato de presidir e o gerente, o ato de gerir, o ente exerce $\mathrm{o}$ ato de ser.

Essa ideia de Tomás - que aproveita a distinção aristotélica entre a potência e o ato - é bastante diferente da noção cultivada pela tradição platônica-agostiniana, na qual não há uma distinção clara entre João da Silva e um homem simplesmente pensado, ideal, analisa Lauand.

O Aquinate remete ao ensino de Aristóteles de que existem diversos modos de ser, sendo a potência um modo fraco de ser e o ato, um modo forte. Ao contrário do pensamento essencialista, Tomás não parte das essências, mas das coisas, dos entes, da realidade, continua Lauand. Isso faz com que o Aquinate conceba uma grande novidade metafísica: para ele, em oposição ao binômio essência/existência, o binômio fundamental a ser considerado é ato de ser/essência (esse, actus essendi/essentia), sendo que a essência é a limitação da recepção do ser, a limitação do recebimento do ser.

Todo ente é e é algo: é homem, é cão, é pedra. Nessa composição, se o responsável pelo é do ente é o ato de ser, seu complemento necessário, a essência, corresponde ao "quê" que o ente é. ${ }^{368}$

Ao afirmar a composição essêncialato de ser - afirma ainda Lauand -, Tomás não considera o ser como algo justaposto, acrescentado a uma essência ideal, como algo separado a que se agrega o ser. "O ato de ser é que é o ponto de partida, o elemento mais fundamental de todos os entes. E a essência é a medida da recepção do ato de ser."369

A essência também não diz respeito a uma realidade isolada, à qual se justaporia o existir, acrescenta Lauand. Em Tomás, ela é entendida como algo intrinsecamente unido ao ente real e concreto, que estabelece os limites, o fim, o término da recepção do ato de ser pelo ente. "Este ente tem uma essência (é pedra, árvore, cão ou homem) por receber o actus essendi em tal e tal forma, em tal medida., ${ }^{, 370}$ A essência tem um princípio de operações a que Tomás dá o nome de natureza: o homem pensa e a árvore dá frutos porque têm uma essência das quais procedem essas capacidades. Sendo o ato puro de ser, Deus não possui essência, pois Ele não tem nenhuma limitação na sua posse de ser.

\footnotetext{
${ }^{367}$ Obra citada, página 61.

368 Jean Lauand, obra citada, página 62.

369 Jean Lauand, obra citada, página 63.

${ }^{370}$ Jean Lauand, obra citada, página 64.
} 
Para Dionísio,

Deus é supraessencial e causa de todas as essências. ${ }^{371}$

Segundo Tomás,

Como toda forma criada assim subsistente tem o ser e não é seu ser, é necessário que seu próprio ser seja recebido e por conseguinte restrito a uma determinada natureza. ${ }^{372}$

Todas as atividades dos entes - falar, germinar, dar frutos - decorrem de sua natureza. Entretanto, isso não acontece com o ser, que não decorre da sua natureza, mas é anterior a ela. Daí por que Tomás considera que "o ser que está presente nas coisas criadas pode somente remontar-se ao ser divino" 373 .

Velde explica essas considerações. Segundo ele, em cada criatura o esse (ser) é algo praeter essentiam e entra em composição com a essência. Nenhuma criatura é seu esse, mas meramente tem esse. Isso significa que algo mais deve estar presente em adição ao esse que é recebido nessa criatura ou participado por ela. Portanto, em cada criatura deve ser feita uma distinção entre a criatura que tem esse e o esse mesmo. Participação evidentemente envolve composição no participante de um princípio recebedor e daquilo que é recebido. Ao mesmo tempo, porém, esse "algo mais" não pode ser um sujeito pressuposto. Sem esse não existe nada, nem mesmo um princípio recebedor. Se a criação é um meio universal de vir a ser, sem nenhum pressuposto para isso (ex nihilo), então o sujeito recebedor deve vir ao ser ao mesmo tempo em que o ser que é recebido. ${ }^{374}$

Lauand nota as importantes consequências dessas afirmações para o pensamento e para a vida. Enquanto as correntes "espiritualistas" da época de Tomás consideravam a matéria como uma limitação e, por isso, recomendavam a negação do mundo como uma atitude necessária para atingir Deus, o Aquinate via exatamente nas coisas criadas o caminho para chegar a Ele, uma vez que elas são "reflexo da divina bondade" ${ }^{375}$. Como diz Lauand:

Tomás é, portanto, decididamente também "materialista". No entanto, essa atitude não se opõe nele à fé; pelo contrário, ajuda a compreendê-la melhor, e vem reforçar um aspecto central que desde sempre esteve afirmado pelo cristianismo: o mundo material é criatura de Deus, não algo oposto a Ele. ${ }^{376}$

\footnotetext{
${ }^{371}$ Dos nomes divinos 2, 11 .

${ }^{372}$ Suma teológica I, 7, 2.

${ }^{373}$ De potentia 3, 5 ad 1. Tradução de Jean Lauand.

${ }^{374}$ Rudi A. te Velde, obra citada, p. 87.

${ }^{375}$ De veritate 22,2 ad 2.

${ }^{376}$ Jean Lauand, obra citada, p. 66.
} 
Em Tomás, a participação aparece sempre associada com a causalidade e apresenta algumas características distintas. Uma delas diz respeito ao fato de que o efeito é menor que a causa. Como mostra Velde, esse tipo de participação causal é ilustrado com o seguinte exemplo: o ar participa na luz do sol, porque o ar é iluminado pelo sol num grau menor de claridade do que a luz do sol em si mesma. A razão de falar em "participação" é o fato de que o efeito recebe algo da causa num modo reduzido. $O$ efeito é insuficiente para sua causa, recebe apenas parcialmente o que a causa tem plenamente e não reduzido.

O participado é maior do que participante, assim como a causa é maior do que o efeito que ela produz. Para Dionísio,

Os atributos são melhores que os sujeitos participantes. Assim é superior a toda participação e a todas as coisas o Autor imparticipável de todos quantos o participam. ${ }^{377}$

Em Tomás, essa tese expressa-se nas seguintes formulações:

$\mathrm{O}$ efeito preexiste virtualmente em sua causa eficiente; mas preexistir na causa eficiente não quer dizer preexistir sob um modo menos perfeito; pelo contrário, mais perfeito. ${ }^{378}$

Sendo Deus a primeira causa eficiente das coisas, as perfeições de todas as coisas devem preexistir em Deus de maneira mais eminente. ${ }^{339}$

Participar significa também receber algo de outrem, mas a coisa recebida não é recebida totalmente. Trata-se de um receber parcial de algo de outro, de acordo com a capacidade do recipiente. É o que diz Dionísio:

(Deus) se dá a todos igualmente em participação, segundo a capacidade receptiva de cada um. ${ }^{380}$

Igualmente para Tomás, há uma medida certa de recebimento do ser:

Mas tudo o que é participado é recebido segundo a capacidade do participante, pois nada pode receber algo além da sua medida. ${ }^{381}$

A participação dos seres envolve graus - eis mais uma característica da participação. Um objeto é mais ou menos quente conforme esteja mais perto ou mais longe da fonte de calor. Da mesma forma, o ente possui mais ser à medida que se

\footnotetext{
${ }^{377}$ Dos nomes divinos XII.

${ }^{378}$ Suma teológica I, questão 4, artigo 2.

379 Suma teológica I, questão 4, artigo 2.

${ }^{380}$ Dos nomes divinos IX.

${ }^{381}$ Comentário às Sentenças I, d. 8, q. 1, a. 2, s.c. 2.
} 
aproxima de Deus e possui menos ser à medida que se afasta de Deus. Dionísio e Tomás concordam também nesse ponto.

Dionísio, por exemplo, afirma:

Há coisas que participam plenamente do Bem, outras mais ou menos privadas dele, algumas participam debilmente e, por último, estão as que recebem apenas um vestígio do Bem. ${ }^{382}$

A Deidade supraessencial estabeleceu a essência de todas as coisas e lhes deu a existência. É próprio da Causa universal, Bondade suprema, chamar à comunhão consigo todas as coisas enquanto a estas é possível. Por isso, todo ser participa de certo modo da Providência que vem da Deidade supraessencial, Causa de tudo. Em realidade, nada pode existir sem que dependa de algum modo daquele que é fonte de todo ser. Dele participam as coisas inanimadas pelo mero fato de existir, pois todo ser deve a própria existência à Deidade transcendente. Os viventes, por sua vez, participam do poder que dá a vida e ultrapassa toda vida. Os seres dotados de razão e inteligência participam da Sabedoria, perfeição absoluta, primordial, que ultrapassa toda razão e inteligência. Fica claro, pois, que estes últimos seres estão mais próximos a Deus, porque de muitas maneiras compartilham com Ele. $^{383}$

Tomás ratifica o pensamento do autor de Dos nomes divinos ao dizer, na famosa passagem em que expõe a "quarta via" para o conhecimento da existência de Deus:

Encontra-se nas coisas algo mais ou menos bom, mais ou menos verdadeiro, mais ou menos nobre etc. Ora, mais e menos se dizem de coisas diversas conforme elas se aproximam diferentemente daquilo que é em si o máximo. Assim, mais quente é o que mais se aproxima do que é sumamente quente. Existe em grau supremo algo verdadeiro, bom, nobre e, consequentemente, o ente em grau supremo, pois, como se mostra no livro II da Metafísica, o que é em sumo grau verdadeiro é ente em sumo grau. Por outro lado, o que se encontra no mais alto grau em determinado gênero é causa de tudo que é desse gênero: assim o fogo, que é quente no mais alto grau, é causa do calor de todo e qualquer corpo aquecido, como é explicado no mesmo livro. Existe então algo que é, para todos os outros entes, causa de ser, de bondade e de toda a perfeição: nós o chamamos Deus. ${ }^{384}$

Outra característica da participação - talvez a mais importante e com mais profundas implicações filosóficas - é que ela permite um certo conhecimento da causa divina através dos efeitos criados. Segundo Velde, o pressuposto básico em Dionísio, assim como em Tomás, é que um efeito manifesta de algum modo a sua causa, uma vez que ele procede da causa de acordo com um modelo inteligível. Uma causa comunica algo da sua perfeição ao efeito, expressa a si mesma no efeito, que deve ser de algum grau similar à sua causa.

\footnotetext{
${ }^{382}$ Dos nomes divinos IV, 20.

${ }^{383}$ Da hierarquia celeste IV, 1.

${ }^{384}$ Suma teológica I, 2, 3.
} 
De acordo com Dionísio, a causa divina produz todas as coisas ao fazê-las participar em perfeições como o Ser, Vida e Sabedoria, perfeições que são chamadas participações da divina bondade. Por meio dessas participações, o mundo criado manifesta de algum modo a divina causa. As participações da bondade de Deus nas criaturas são como que manifestationes da origem divina no mundo, são as divinas processões (processiones) para as criaturas que recebem esses dons da bondade de Deus, sustenta Velde ${ }^{385}$.

Ou seja, embora o participante não seja igual ao participado - assim como um efeito não possui a mesma potência da causa que lhe dá origem -, existe alguma semelhança entre ambos. As criaturas se assemelham de algum modo ao Criador, uma vez que todo efeito traz em si algo de sua causa. Assim, todo e qualquer ente espelha a Deus, pela essência e pelo ato de ser.

\section{Como afirma Dionísio:}

(As coisas) são semelhantes a Ele no sentido de que participam de certo modo daquele que não pode ser participado. ${ }^{386}$

\section{Com palavras diferentes, Tomás de Aquino expressa o mesmo conceito:}

Como os efeitos não têm a plenitude de suas causas, não lhes compete o mesmo nome e definição. No entanto, é necessário encontrar entre uns e outros alguma semelhança, pois é da própria natureza da ação que o agente produza algo semelhante a si, já que todo agente age segundo o ato que é. Daí que a forma do efeito encontra-se a outro título e segundo outro modo na causa. Assim, o sol causa o calor nos corpos inferiores agindo segundo o calor que ele é em ato: então é necessário que se afirme alguma semelhança entre o calor gerado pelo sol nas coisas e a virtude ativa do próprio sol, pela qual o calor é causado nelas. Daí que se acabe dizendo que o sol é quente, se bem que não segundo o mesmo título pelo qual se afirma que as coisas são quentes. Assim também Deus, que distribui todas as suas perfeições entre as coisas, é-lhes semelhante e, ao mesmo tempo, dessemelhante. ${ }^{387}$

A criatura é trevas na medida em que provém do nada; mas, na medida em que provém de Deus, participa de uma certa semelhança com Ele e conduz à semelhança com Ele. ${ }^{388}$

Todas as coisas, na medida em que são, assemelham-se a Deus, que é o ser primeiro e principal. ${ }^{389}$

Todas as coisas, na medida em que são, reproduzem de algum modo a essência divina; mas não a reproduzem todas da mesma maneira, mas de modos diferentes e em diversos graus. Assim, o protótipo e o original de cada

\footnotetext{
${ }^{385}$ Obra citada, p. 93.

${ }^{386}$ Dos nomes divinos IX.

${ }^{387}$ Suma contra os gentios I, 29, 2.

${ }^{388}$ De veritate 18,2 ad 5. Tradução de Jean Lauand.

${ }^{389}$ Contra os gentios 1, 80. Tradução de Jean Lauand.
} 
criatura é o próprio Deus, na medida em que este é reproduzido de determinada maneira por determinada criatura. ${ }^{390}$

Essa visão tomasiana da participação dos seres em Deus recebe sua forma poética na obra da poetisa brasileira Adélia Prado. Poucos autores conseguiram, como ela, expressar tão bem a ideia de que as mais simples e comezinhas coisas do cotidiano estão impregnadas do divino - ainda que remotamente, como diz Tomás -, em razão de sua origem divina. Tome-se como exemplo este verso:

De vez em quando Deus me tira a poesia.

Olho pedra e vejo pedra mesmo ${ }^{391}$

Com fina sensibilidade, a poetisa nota que pedra é mais do que apenas pedra. Onde a maioria das pessoas vê apenas um objeto inanimado, Adélia sente que esse objeto participa da sua causa primeira e, por isso, está marcada pela transcendência algo que ela só deixa de perceber quando Deus lhe tira a poesia e a inspiração. Participação que se dá na criação, mas também na elevação à graça e na Redenção:

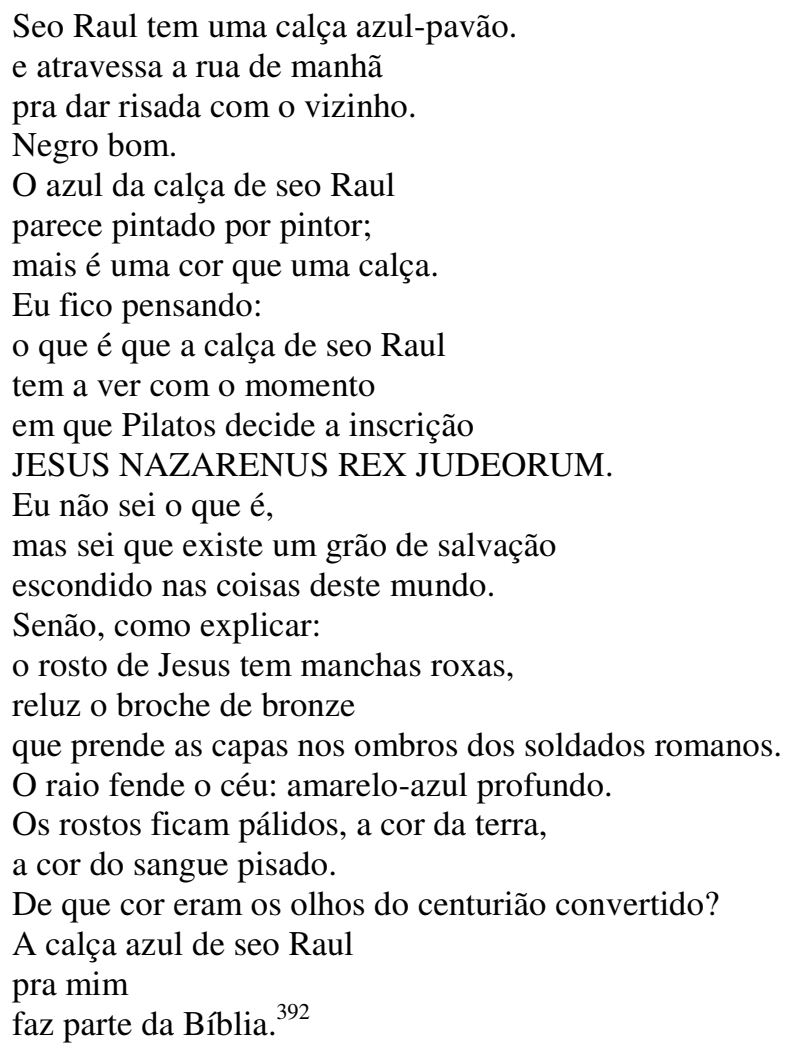

Em, em outro momento:

Frigoríficos são horríveis

\footnotetext{
${ }^{390}$ Quodl. 4, 1.

391 Adélia Prado, Poesia reunida, p. 199.

392 Adélia Prado, "A poesia, a salvação e a vida", Poesia Reunida, São Paulo, Siciliano, 1991, p.216.
} 
mas devo poetizá-los

para que nada escape à redenção

Frigorífico do Jibóia

Carne fresca

Preço jóia ${ }^{393}$

A presença da transcendência no cotidiano é reproduzida em vários outros poemas de Adélia, como "Casamento":

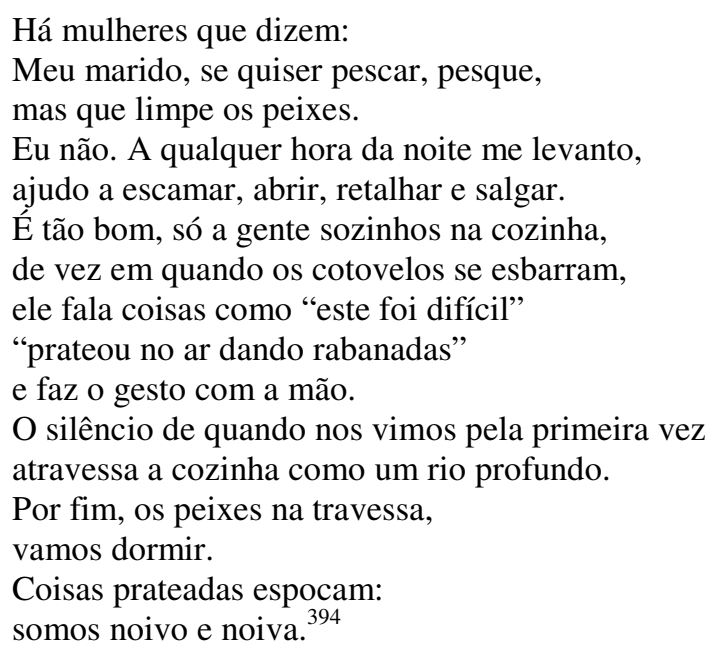

A mística presente nas mais triviais coisas do dia a dia - como limpar peixes de madrugada - tornou-se inacessível ao homem contemporâneo, que, ofuscado por um racionalismo exacerbado, se vê incapaz de perceber nelas a origem divina, como aponta Lauand:

\begin{abstract}
...a realidade deixou de ser objeto de contemplativa admiração e passou a ser considerada meramente como opaca matéria-prima. Pois a discreta simplicidade dos valores da poesia escapa à sufocante mentalidade consumista e massificada, amarga e reivindicatória do homem que se pretende auto-suficiente num mundo tecnologicamente domesticado, que, quando muito, só se deixa atingir por "efeitos especiais". 395
\end{abstract}

Outro poeta que soube expressar com beleza artística o tema da participação foi o modernista Murilo Mendes. No "Poema espiritual"396, ele afirma:

Eu me sinto um fragmento de Deus ${ }^{397}$

Como sou um resto de raiz

Um pouco de água dos mares

\footnotetext{
393 Adélia Prado, "Duas horas da tarde no Brasil”, Poesia Reunida, São Paulo, Siciliano, 1991, p.326.

${ }^{394}$ Adélia Prado, Poesia reunida, São Paulo, Siciliano, 1991, p. 252.

395 Jean Lauand, "Tomás de Aquino e os fundamentos do Belo (a mística poética de Adélia Prado), em Revista Dominicana de Teologia, $\mathrm{n}^{\circ}$ 8, jan-jun 2009, p.7-30

${ }^{396}$ Esse poema foi-me indicado pelo estudante Jonathas Ramos de Castro, a quem agradeço por ter-me apontado nele o tema deste capítulo.

${ }^{397}$ Essa expressão dá margem a uma acusação que desde sempre o Pseudo-Dionísio Areopagita foi vítima: a de panteísmo. Mas pode-se lê-lo dentro dos estritos parâmetros da doutrina da participação: as coisas participam de Deus e, nesse sentido, revelam algo dele, apesar do abismo entre criatura e Criador. Ou, como o poeta mesmo diz, elas são "formas visíveis do invisível”.
} 


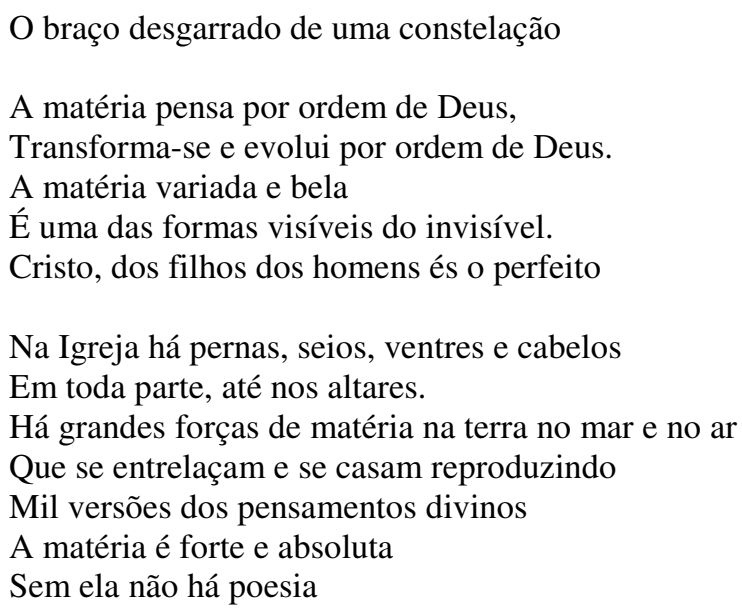

Tão bem intuída por Adélia Prado e Murilo Mendes, a similaridade entre causa e efeito - entre os seres criados e sua origem divina - conduz à pergunta sobre em que consiste exatamente essa similaridade e de que maneira Deus, como Criador, é expresso em sua obra. Como mostra Velde, Tomás enfatiza que a semelhança que cada criatura traz do seu criador é "deficiente", está aquém de como Deus é em si mesmo. A inteligível conexão entre criatura e criador não é tal que a forma da criatura nos capacita a dizer positivamente qual é a "forma" de Deus. Portanto, nenhum nome pode ser predicado univocamente, de acordo com o mesmo significado, a partir da semelhança entre criatura e Deus. Por conta da deficiência da semelhança no efeito, Tomás costuma falar de um agens analogicum ${ }^{398}$, um agente para o qual o efeito tem apenas uma semelhança de acordo com uma certa analogia. A criatura é, somente num reduzido modo, similar à sua causa divina. ${ }^{399}$ Os próprios termos com que Tomás descreve a inteligível conexão entre Deus e as criaturas são depreciativos. É apenas num remoto e deficiente modo ${ }^{400}$ (remote et deficienter) que a criatura tem uma semelhança com a divina bondade. Essa deficiência é mostrada pela multiplicidade na criação do que é unificado e simples em Deus. Criação parece ser como uma dispersão na multiplicidade de diversos "fragmentos" de uma divina plenitude de perfeição.

Se a relação entre a causa e seus efeitos dá-se remote e deficienter, como, então, a criatura revela o Criador? Para resolver essa questão, aponta Velde, Tomás cita ${ }^{401}$ as palavras do primeiro capítulo do livro de Gênesis: "Façamos o homem à nossa imagem e semelhança". A partir disso, ele conclui que uma criatura não pode ser totalmente

\footnotetext{
${ }^{398}$ Suma teológica I, 13, 5, ad. 1.

${ }^{399}$ Rudi A. te Velde, obra citada, p. 96.

${ }^{400}$ Suma teológica I, 6, 4: "Portanto, deste primeiro que é ente e bom por essência, cada coisa pode ser dita boa e ente, enquanto dele participa por certa assimilação, mesmo remota e deficiente".

${ }^{401}$ Suma teológica I, 4.
} 
dessemelhante a Deus, uma vez que é feita por Deus. Por esse ato de criação, Deus estabelece uma relação positiva de algo mais consigo mesmo. Porque a criatura tem o que é de Deus, diz-se corretamente que é similar a Deus. Mas o contrário não é verdadeiro: porque Deus não tem nada que é da criatura, Deus não pode ser dito ser similar à criatura. O seu relacionamento de similaridade não é, portanto, recíproco.

Recolho, nos próximos parágrafos, mais considerações de Rudi A. te Velde sobre esse aspecto da participação dos seres na causa divina ${ }^{402}$.

A similaridade das criaturas com Deus está fundada na relação causal da criação. O ponto de partida é o princípio de que causa e efeito devem ser de algum modo similares. Porém, o grau em que o efeito é similar à sua causa pode variar. A mais perfeita similaridade existe onde causa e efeito correspondem nas mesmas espécies. Nesse caso, a forma da causa retorna no efeito de acordo com a mesma ratio, de modo que ambos, causa e efeito, são chamados univocamente. Esse tipo de causalidade unívoca (agens univocum) é característica do processo natural de geração. Fogo gera fogo e homem gera homem (homo generat hominem). Aí existe completa sinonímia entre causa e efeito.

Se o efeito não é similar à causa de acordo com a mesma espécie, ele pode corresponder a ela num sentido remoto, por exemplo, em gênero (secundum similitudinem generis). Tomás menciona o sol como um exemplo dessa causalidade genérica. O que é gerado pelo poder do sol não recebe a forma do próprio sol, como se fosse outro sol, mas algo do calor do sol, pela razão que a natureza gerada tem uma certa afinidade e semelhança com o sol.

Tomás continua: se existe uma causa que não se dá sob um gênero, o grau de similaridade entre causa e efeito será até menos perfeito e determinado. Nesse caso, o efeito é similar à sua causa não de acordo com a mesma espécie ou gênero, mas meramente de acordo com uma certa analogia ${ }^{403}$. Precisamente por conta dessa similaridade reduzida, diz-se que o efeito "participa na similaridade da causa" ${ }^{\star 404}$. Tudo o que é causado por Deus participa por modo de uma certa semelhança em Deus, não de acordo com a mesma espécie ou até o mesmo gênero, mas em relação ao ser que é comum a todas as coisas. Assim, todas as criaturas, na medida em que são seres, são similares a Deus como o primeiro e universal princípio de todo ser. Portanto, embora a

\footnotetext{
${ }^{402}$ Rudi A. te Velde, obra citada, p. 98-100.

${ }^{403}$ Suma teológica I, 4, 3.

${ }^{404}$ Comentário às Sentenças II, 16, 1, a. 2.
} 
similaridade seja remota e reduzida, até no caso da criação existe uma certa sinonímia entre causa e efeito, que marca a conexão inteligível entre eles: cada criatura é de algum modo similar a Deus no sentido de que "seres procedem do (primeiro) ser". Mas essa similaridade é permeada por uma diferença fundamental, pois o primeiro ser difere dos outros seres por sua diferente relação consigo mesmo: Deus é ser por sua essência, a criatura é ser por participação. ${ }^{405}$

A recorrente utilização, por Dionísio e Tomás, da imagem do sol como uma metáfora do poder criador de Deus pode trazer alguns problemas de interpretação, como também nota Velde. Comparada ao poder universal do sol de produzir uma multiplicidade de efeitos, a criação é pensada em termos de emanação ou diffusio. Criação seria como que um jorro da infinita bondade de Deus numa multiplicidade de vários seres, cada um deles refletindo, ao seu modo, a simples e perfeita bondade de Deus. Trata-se de um clássico conceito neoplatônico, em que a causalidade por emanação está inextricavelmente ligada ao caráter de necessidade, de acordo com o qual um efeito emana de sua causa em virtude da natureza dessa causa.

Segundo essa imagem neoplatônica, a criação é considerada um necessário transbordamento da superabundância da divina bondade, uma "queda ontológica" da original unidade até a multiplicidade dispersa e sem ordem. Tal ideia se encontra em Dionísio, para quem a participação ocorre também como um ato da bondade de Deus, que se deixa participar. Dionísio transmite a ideia de que a Criação é consequência do extravasamento, do transbordamento da bondade de Deus. Sumamente bondoso, Deus não poderia ficar encerrado em si mesmo - atitude tipicamente egoísta, portanto contrária à generosidade própria de quem é bom -, mas, justamente em virtude de sua bondade, fez transbordar esse sentimento na forma da dádiva da Criação, doando ser, vida, respiração e toda a estupenda maravilha e beleza presentes no mundo ${ }^{406}$. Dionísio diz assim:

O autor de todas as coisas, por superabundância de bondade, ama todas as coisas, faz todas as coisas, aperfeiçoa todas as coisas, mantém unidas todas as coisas e volta-se para todas as coisas, e também o amor divino é o bem, a partir do bem, através do bem. Pois Ele, o amor benfeitor dos seres,

\footnotetext{
405 Suma teológica I, 4, 3, ad. 3: "Não se afirma haver semelhança entre Deus e a criatura em razão da comunicação de uma forma segundo a mesma razão genérica e específica, mas apenas segundo uma analogia, pois Deus é ente por essência, os outros por participação".

${ }^{406}$ Para aclarar essa ideia, pode-se fazer um paralelo entre a visão neoplatônica do mundo e a figura do verdadeiro professor. O professor que é mestre de verdade possui profunda e autêntica bondade e generosidade. Ao invés de encerrar em si os seus conhecimentos, faz transbordar esse saber a seus alunos, com o sincero desejo de que estes aprendam com prazer. Essa parece ser uma boa metáfora para assinalar a bondade de Deus ao criar o mundo.
} 
preexistindo no bem, por superabundância, não o permitiu permanecer estéril nele mesmo, mas moveu-o para operar segundo a superabundância geradora de tudo. ${ }^{407}$

\section{Afirma também Dionísio:}

(A Deidade) se entrega como dom, transbordando, de modo que todas as coisas participem de sua bondade. ${ }^{408}$

O problema dessa imagem, porém, é que ela se torna incompatível com o modo bíblico de falar em termos da sabedoria ordenadora de Deus, que dispõe todas as coisas em "número, peso e medida". A imagem da diffusio, dado seu caráter de necessidade, falha em explicar como a multiplicidade dos efeitos pode ser planejada criativamente pela causa primeira.

A resposta a essa questão se encontra em Dionísio, segundo a interpretação que Tomás oferece de um trecho de Dos nomes divinos. Nesse livro, Dionísio afirma que o sol ilumina por si mesmo, sem deliberação ou preferência por uma sobre a outra, todas as coisas visíveis, cada uma das quais participa na luz de acordo com sua própria medida; da mesma forma o Bem, superior ao sol como o arquétipo é superior a uma imagem obscura, emite os raios da sua inteira bondade por sua essência para todos os seres, cada um de acordo com sua própria maneira. ${ }^{409}$

Em seu comentário - destaca Velde -, Tomás observa que significativamente Dionísio não repete a frase "sem deliberação ou preferência" com respeito a Deus. Como o sol age em virtude de seu ser, Deus dá bondade para todas as coisas per suam essentiam, mas não necessitado por sua natureza. Mesmo que o sol tenha uma vontade, ainda assim irradiaria pela espontaneidade de sua natureza, desconsiderada a vontade do sol. Mas para Deus o ser é idêntico a conhecer e desejar: o que ele faz per suum esse ele faz, portanto, conscientemente e espontaneamente. Que Deus age por sua essência não exclui, e sim implica, a liberdade. A esse respeito, a imagem da difusão natural do sol é inadequada. Assim, ainda que uma criatura possa ser chamada uma "emanação" de Deus, não se trata de uma emanação natural. O que é produzido por um agente consciente e espontâneo é como ele é conhecido (e planejado) pelo agente, não como o agente é de acordo com o seu ser. O efeito do Deus eterno, portanto, precisa não ser eterno por si mesmo. Como um agente inteligente, Deus produz a criação como ele

\footnotetext{
${ }^{407}$ Dos nomes divinos IV, 10.

${ }^{408}$ Dos nomes divinos II.

${ }^{409}$ Dos nomes divinos IV, 1.
} 
pretende que ela seja, de acordo com suas próprias condições e como distinta do modo de ser de Deus. ${ }^{410}$

Retomo a seguir mais análises de Velde sobre essa questão, que por sua clareza e exatidão merecem ser fixadas. ${ }^{411}$

Para explicar como uma pluralidade de efeitos pode ser planejada por um ato singular de Deus, Tomás faz uma distinção entre um agens per artem e um agens per naturam. Por exemplo, a geração natural (como no caso em que homo generat hominem) se refere à ação um agente natural. Nesse caso, a forma do efeito assimila o agente em sua natureza. Porém, se um homem, ao invés de gerar outro homem, faz uma obra de arte, ele age como um agens per artem. O efeito de um agente por arte é similar ao conceito que existe na mente desse agente. Uma obra de arte, por exemplo, não é simplesmente uma auto-expressão do artista, e sim uma expressão do que o artista concebeu em sua mente.

Ambos, natureza e arte, têm um papel no ato de criação de Deus. Deus cria as coisas por seu intelecto, portanto, em virtude da sua arte, mas não sem a ação da sua natureza (actio naturae). Quando um artífice humano produz uma coisa, o exercício dessa sua habilidade requer uma ferramenta de natureza externa a si mesmo. Deus, em contraste, exercita sua habilidade em virtude da sua própria natureza. A arte e a natureza de Deus estão envolvidas em sua ação criativa.

Do ponto de vista do modelo emanação somente, a divisão e multiplicação no efeito podem ser tomadas como um sinal de uma "queda" da unidade original da causa. Porém, do ponto de vista de uma emanação criativa, de acordo com sabedoria e arte, a diversidade ordenada na criação caracteriza seu status como uma obra bem feita, que representa a bondade da sua causa, não na forma da própria causa, mas em sua maneira distinta, como planejada e pré-concebida pela causa. As criaturas formam uma realidade substancial com uma consistência própria e, existindo em si mesmas. elas têm sua própria verdade específica, que não pode ser simplesmente reduzida à mais alta verdade em sua origem.

Deus é um agens per artem e, portanto, é capaz de produzir diretamente, de acordo com a concepção de sua sabedoria, uma multiplicidade de coisas. Mas ele também permanece um agens per naturam. As criaturas têm semelhança com o Criador não somente no sentido que eles se parecem com sua ideia na mente de Deus. "É por

\footnotetext{
${ }^{410}$ Tomás de Aquino, Comentário aos Nomes divinos IV, lect. 1.

${ }^{411}$ Rudi A. te Velde, obra citada, p. 103-108.
} 
causa da perfeição da divina natureza que, pelo poder da divina natureza, uma similaridade da sua natureza é comunicada às criaturas, embora essa comunicação aconteça pelo desejo de Deus" (De pot. q. 3, a. 15 ad 2). A criação, assim, não se dá sem uma actio naturae de Deus. Pois apenas com base nessa actio naturae, que resulta numa similitude da divina natureza em todas as coisas criadas por Deus, a relação de origem de todas as coisas ao princípio universal único é inteligível.

O que é exatamente a actio naturae de Deus? E o que é a semelhança da divina natureza comunicada a todas as criaturas? Deus não necessita de nada externo a ele para realizar sua criação. A perfeição contida em sua natureza é mais do que suficiente para produzir cada coisa de acordo com a "porção" de perfeição que ela requer para se tornar como Deus a concebeu. Pois a natureza de Deus (ou essência) é puro ato (actus purus) e compreende na unidade a plenitude de ser; por isso Deus está em ato com relação a cada ser possível. Qualquer que seja seu determinado modo de ser e apesar de muito diversos e desiguais, na medida em que todas as coisas compartilham no ser, elas podem ser entendidas como derivadas do único princípio e origem comum. $\mathrm{O}$ efeito próprio de Deus, de acordo com o qual cada coisa assimila sua natureza, é ser; e portanto, Tomás afirma, é esse "ser" em que consiste a natureza ou substância de Deus. Conceder ser é a ação própria do que é ser em si mesmo. E o ser que Deus concede para todas as coisas pela ação da sua natureza é recebido em cada coisa determinada de acordo com a concepção da sua sabedoria, de acordo com o modo específico como ele quer que cada coisa seja. A semelhança comum das criaturas em virtude do seu ser é, por assim dizer, "especificada" em cada coisa de acordo com sua própria natureza. A arte de Deus é o princípio dessa especificação e determinação como as coisas recebem ser.

Em resumo, além da comparação dionisiana com a natural generosidade do sol, Tomás emprega outro modelo, de acordo com o qual a criação é entendida como uma obra de arte. Deus é como um artifex que produz uma obra segundo uma ideia préconcebida. Na base da sua ars, Deus produz, consciente e voluntariamente, um efeito de acordo com sua própria ideia, que determina como esse particular efeito deve ser feito. Por isso, pode-se falar de dois modelos diferentes de criação - por emanação e por arte.

Essas análises de Velde sobre a criação de Deus per artem, e não apenas per naturam, coincidem com a intuição de Lauand a respeito do Logos ludens, o Deus que cria brincando. Abordando a questão do lúdico no pensamento de Tomás de Aquino, Lauand observa que o Aquinate analisa esse tema sob dois pontos de vista - o ético e o teológico. No primeiro caso, Tomás, seguindo a Ética de Aristóteles, lembra que o 
brincar é uma virtude moral necessária à vida humana, que leva os homens a ter graça, bom humor, jovialidade e leveza no falar e no agir, tornando o convívio humano descontraído, acolhedor, divertido e agradável. ${ }^{412}$

Mas é no que se refere à teologia da Criação que o pensamento de Tomás sobre o lúdico se torna ainda mais profundo. Citando um versículo do livro bíblico de Provérbios - "Com Ele estava eu, compondo tudo, e eu me deleitava em cada um dos dias, brincando diante dEle o tempo todo, brincando no orbe da terra e as minhas delícias são estar com os filhos dos homens" ${ }^{\star 13}$, conforme a tradução latina de que dispõe -, o Aquinate afirma que o mundo é o resultado de uma brincadeira do Logos. Este, conforme o Evangelho de João, não é só imagem do Pai, mas também princípio da Criação, que é uma obra inteligente de Deus, projeto, design das formas da realidade, feita por Deus por meio de seu Verbo, o Logos - o que permite ao homem o conhecimento das coisas criadas, pois, como projeto, são passíveis de ser apreendidas pela razão humana.

Esse Logos estava com Deus no princípio, brincando enquanto compunha todas as coisas. Daí que a Criação adquire, ao mesmo tempo, um caráter lúdico e, por isso, não possui necessariamente uma lógica e uma finalidade. Da mesma forma como se dá nas atividades do brincar, que não se buscam por um fim extrínseco, mas pelo prazer que dão em si mesmas, também o ato da Criação pode ser concebido como algo voltado para o mero deleite da contemplação, sem que se sujeite à férrea lógica do utilitarismo.

Numa entrevista publicada recentemente, Lauand explicou esse tema de forma simples e coloquial:

O brincar é uma das poucas atividades humanas que têm um fim em si mesmas, como o filosofar, a arte e a poesia. Tem a ver com o imprevisível. Não segue a lógica férrea do Logos. Como o brincar das crianças, não há nele uma razão aparente. Ele implica o mistério das coisas, a incognoscibilidade. Isso significa que não temos que ficar tentando encontrar razões lógicas para todas as coisas, porque elas estão envoltas nesse caráter lúdico que resgata o mistério, o imprevisível, o incognoscível. ${ }^{414}$

Se pensássemos na Criação apenas como ação do Logos, correríamos o risco de cair num racionalismo frio e duro. Como há também o elemento lúdico,

\footnotetext{
412 Jean Lauand, "Deus ludens - O lúdico no pensamento de Tomás de Aquino e na pedagogia medieval", em Em diálogo com Tomás de Aquino - Conferências e ensaios, São Paulo, Mandruvá, 2002, p. 19. Lauand lembra que a moral, na concepção de Tomás, está relacionada com o ser do homem, com o que o homem é e está chamado a ser, ou seja, com a sua auto-realização. Assim, a norma moral "não matar", por exemplo, se refere ao fato de que o homem é um ser constituído de tal forma que é incompatível com tirar a vida de uma pessoa. Portanto, tratando-se de uma virtude moral, o lúdico adquire uma importância fundamental, porque ele contribui para que o homem se aproxime dessa auto-realização. Em sentido inverso, pode-se pensar também que o homem não dado ao lúdico, ao brincar, está se afastando desse objetivo.

${ }^{413}$ Provérbios 8:30-31.

${ }^{414}$ In Roberto C. G. Castro, O intérprete do Logos - Textos em homenagem a Jean Lauand, 2009, p. 24.
} 
devemos mais é admirar a Criação, reconhecendo o bom humor de Deus ao fazer as coisas. A atitude mais razoável é aceitar o mundo com muito humor, eu diria com uma boa gargalhada, sabendo que jamais poderemos apreendêlo na estrutura férrea da lógica. ${ }^{415}$

Acrescente-se, que, ainda que os seres revelem algo de Deus, a essência divina, como diz Dionísio, permanece oculta e como tal não é manifestada pelas participações em seus efeitos. Velde lembra que Tomás considera a criação como uma revelação a respeito de Deus, um tipo de divina "distinção" (divina discretio) numa multiplicidade de efeitos distintos, mas essa discretio não considera a divina essência em si mesma, mas sua semelhança (similitude), que, como tal, difere da essência. A essência de Deus permanece "imparticipada e incomunicada" (imparticipata et incommunicata). As criaturas não resultam de uma diferenciação da essência divina em muitas partes, explica Velde. Elas são as muitas parciais "semelhanças" nas quais a semelhança da essência de Deus é distinguida e multiplicada. É através da sua similitude que a divina causa é "propagada e multiplicada" em suas criaturas. ${ }^{416}$

Para Velde, essa passagem do comentário de Tomás sobre o De divinis nominibus ensina dois importantes aspectos da participação. Primeiro, o efeito não participa na causa em si, mas em sua similitude. Se as criaturas procedem de Deus através da participação, isso não significa que a divina causa é participada pelas criaturas. Como já foi dito, criação não é um tipo de expansão divina, como se as criaturas fossem uma realidade semi-divina. Como afirma Tomás:

Deus permanece imparticipado acima de todas as coisas pela singularidade de sua substância. ${ }^{417}$

Que Deus não é participado diretamente é uma ideia que também se encontra no Pseudo Dionísio Areopagita:

Não participamos diretamente de Deus. Nós o fazemos por meio de dons que
procedem dele; nós os chamamos efeitos da substância por si, vida por si,
deificação por si. Os seres que participam desses dons, segundo suas
possibilidades, são e se chamam "possuidores de substância", "viventes",
"divinos" e de modo semelhante.

O segundo aspecto da participação que sobressai do comentário de Tomás é que a similitude da divina essência é multiplicada e distinguida em muitos e diversos efeitos, cada um deles trazendo uma semelhança em um modo distinto e parcial. Portanto,

\footnotetext{
${ }^{415}$ Idem, obra citada, p. 25.

${ }^{416}$ Comentário aos Nomes divinos II, lect. 3.

${ }^{417}$ Comentário aos Nomes divinos II, lect. 4.

${ }^{418}$ Dos nomes divinos XI.
} 
nenhuma criatura recebe a plena e indivisível semelhança de Deus, de modo que expressasse a causa divina adequadamente. Junto com a diferenciação em muitos efeitos, cada efeito possui apenas uma reduzida semelhança da sua causa.

Essa é a razão pela qual, apesar da presença fundante do Criador em todas as coisas, a participação dos seres em Deus não implica o panteísmo. A Criação, tendo sido feita ex nihilo (a partir do nada), provoca uma separação abissal entre as criaturas e o Criador. Lauand lembra que, ao tratar da Criação, Tomás enfatiza este conceito: a criatura tem o ser por participar do ser de Deus, que é ser $^{419}$. "Fica excluída qualquer possibilidade de um Universo divino, e fica excluída, portanto, qualquer visão do ser humano como simples 'gota d'água' nesse 'oceano de divindade', sem liberdade e sem responsabilidade. $" 420$

Lauand acrescenta:

\begin{abstract}
A criação não é entendida por Tomás como um começo, mas como uma situação: a presença fundante do Criador no ente criado. Ou seja, se somos, é porque Deus nos mantém continuamente no ser. Dependemos dele, da forma mais profunda e absoluta, e tudo nos vem deste primeiro ato "fundacional". Mesmo quem se volta contra Deus está sendo por Ele mantido no ser, amparado em cada instante e em cada ato que realiza. ${ }^{421}$
\end{abstract}

Contra o panteísmo, Dionísio afirma:

A Deidade, causa de todo ser, supera infinitamente esses exemplos. É imparticipável. Seus participantes não têm ponto de contato nem mescla alguma com a Deidade, que tudo transcende. ${ }^{42}$

Poderia parecer haver uma multiplicação de deuses pela divinização de almas, cuja participação de Deus as faz semelhantes a Ele. Mas, na realidade, Deus é o Arquétipo, o Único que vive supraessencialmente. ${ }^{423}$

Na realidade, não há perfeita e absoluta semelhança entre causa e efeitos. Estes levam consigo a marca de suas origens somente como podem, enquanto que as causas, independentes dos efeitos, os transcendem por sua própria natureza de princípios. ${ }^{424}$

Depois de conhecer as essas concepções de Tomás sobre o ser e a participação, torna-se fácil entender o conceito de graça segundo o Aquinate. Para ele, se o ser se dá por participação no puro ato de ser, que é Deus, a graça é "ter - por participação na filiação divina que é em Cristo - a vida divina que é na Santíssima Trindade"425.

\footnotetext{
419 Jean Lauand, obra citada, p. 56-57.

${ }^{420}$ Jean Lauand, obra citada, p. 65.

${ }^{421}$ Jean Lauand, obra citada, p. 65.

${ }^{422}$ Dos nomes divinos II.

${ }^{423}$ Dos nomes divinos II.

${ }^{424}$ Dos nomes divinos II.

${ }^{425}$ Jean Lauand, obra citada, p. 56-57.
} 
É o que sustenta Tomás de Aquino:

A graça é uma certa semelhança com Deus de que o homem participa. ${ }^{426}$

O primeiro efeito da graça é conferir um ser de alguma forma divino. ${ }^{427}$

Pela graça santificante, toda a Trindade passa a morar na alma. ${ }^{428}$

Essa concepção de graça como participação do cristão na vida divina está em Dionísio, que afirma:

Ele (Deus) nos criou à imagem de sua eterna formosura e fez-nos partícipes de suas propriedades divinas, para nos elevar espiritualmente. ${ }^{429}$

Nossa salvação só é possível por deificação, que consiste em fazer-nos semelhantes a Deus e nos unir com Ele o quanto nos é possível ${ }^{430}$

A filiação à vida divina se dá com a entrada na vida cristã através do batismo, como diz Tomás:

O batismo consiste em certa regeneração espiritual. Assim como a vida do corpo não a temos senão nascendo corporalmente, assim também a vida do espírito, a vida da graça, não a podemos obter senão mediante um renascimento espiritual. Esse renascimento espiritual se efetua por meio do batismo: "Quem não nascer da água e do Espírito Santos não pode entrar no reino de Deus" (João 3:5). ${ }^{431}$

Por sua vez, Dionísio refere-se à cerimônia do batismo como "iniciação simbólica ao santo nascimento de Deus na alma"432

Novamente é Lauand quem detalha a questão:

A graça nos dá uma união íntima com Cristo: pelo batismo somos como que enxertados em Cristo e principia em nós a in-habitação da Trindade, que se chama vida sobrenatural. Essa nova vida não é que elimina a vida natural nem a ela está justaposta; pelo contrário, empapa-a, informa-a, estrutura-a por dentro. A espiritualidade cristã (...) dirige-se a que descubramos e cultivemos essa vida interior, também e principalmente em nossa vida cotidiana. Pois, pelo batismo, Cristo habita em nós e a vida cristã (...) nada mais é do que a busca da plenitude desse processo - realizado pelo Espírito Santo - de identificação com Cristo, que principia no batismo (...). ${ }^{433}$

E prossegue dizendo que o cristão é aquele que recebeu e tem a própria vida de

Cristo. Mais do que um seguidor de normas e preceitos, ele está chamado a ser um outro

${ }^{426}$ Suma teológica III, 2, 10 ad 1.

${ }^{427}$ Suma teológica III, 2, d. 26, 155.

${ }^{428}$ Suma teológica I, 43, 5.

${ }^{429}$ Da hierarquia eclesiástica III, III, 7.

${ }^{430}$ Da hierarquia eclesiástica I, 3.

${ }^{431}$ Comentário ao Credo dos Apóstolos X.

${ }^{432}$ Da hierarquia eclesiástica II, III, 1.

${ }^{433}$ Jean Lauand, "A filosofia da educação no novo Catecismo Católico" em Filosofia, linguagem, arte e educação, Factash/Cemoroc, São Paulo, 2007, p. 113. 
Cristo no mundo. Estar presente nos cristãos é uma das formas de Cristo perpetuar sua presença no mundo, em todos os lugares e em todas as épocas, acrescenta Lauand. "É isto o que se chama graça: a participação da vida divina em nós."

Assim, ainda de acordo com Lauand, a graça recebida pelo batismo é uma realidade nova, uma vida nova, uma luz nova, uma qualidade nova que capacita a alma a acolher dignamente, para nela habitar, as três pessoas da Trindade. É uma participação na vida íntima de Deus. A alma passa a ter uma vida nova: nela habita a Trindade.

Da mesma forma como ocorre na doutrina do ser, também no que se refere à graça Tomás descarta qualquer tipo de panteísmo, nota Lauand. O cristão não é um "pequeno deus". Persiste a oposição entre ter e ser: Deus é a vida divina, enquanto o cristão tem, por participação nele, essa vida.

Nota-se, assim, que Tomás de Aquino utiliza os mesmos conceitos para explicar tanto a doutrina do ser como a doutrina da graça. A diferença reside no fato de que a primeira diz respeito ao mundo natural e a segunda se refere ao relacionamento sobrenatural do homem com Deus. Lauand cita a interessante comparação que Tomás de Aquino faz entre Criação e graça:

\begin{abstract}
Ambos são dom, favor e amor gratuito de Deus; mas a criação é, como diz S. Tomás, o amor comunnis (o amor geral) de Deus às coisas: o amor com que Deus ama as plantas, a formiga, a estrela; entes que são por um ato de amor e volição divina. Mas, além desse "amor comum", há ainda (formulação também de Tomás) um amor specialis, pelo qual Deus eleva o homem a uma vida acima das condições de sua natureza (vida sobre-natural) e o introduz numa nova dimensão do viver. ${ }^{435}$
\end{abstract}

No plano natural, diz ainda Lauand ${ }^{436}$, todas as criaturas participam do ser e, portanto, da natureza divina. Elas refletem, por isso, a bondade, a verdade e a beleza de Deus. Já no plano sobrenatural, ocorre uma participação na natureza divina como divindade, uma participação em Deus enquanto Deus, um “tornarmo-nos Deus". "Passamos a ser divinae naturae consortes (...), participantes da própria vida íntima de Deus. E isto, diz Tomás, é a graça." 437

Esse conceito de graça como participação na vida íntima de Deus - tal como expresso por Tomás de Aquino - está claro no Novo Testamento. Na Carta aos Hebreus, por exemplo, lê-se:

\footnotetext{
${ }^{434}$ Jean Lauand, obra citada, p. 113.

435 Jean Lauand, Filosofia, linguagem, arte e educação, p. 113-114.

${ }^{436}$ Jean Lauand, Oriente \& Ocidente: razão, natureza e graça - Tomás de Aquino em sentenças, Centro de Estudos Árabes da USP/Edix Edições, sem data.

${ }^{437}$ Jean Lauand, obra citada, p. 30-31.
} 
(...) porque temos nos tornado participantes de Cristo (...). ${ }^{438}$

Mas Deus nos disciplina para aproveitamento, a fim de sermos participantes da sua santidade. ${ }^{439}$

A mesma ideia aparece nos textos do apóstolo Pedro, para quem Deus concedeu aos cristãos "preciosas e grandes promessas" com o objetivo de torná-los "coparticipantes da natureza divina" 440 .

No Evangelho segundo João, encontra-se um discurso de Cristo aos seus discípulos que faz referência direta à participação do cristão na vida divina. Como é comum, Cristo utiliza uma metáfora. Ele se compara a uma videira e os discípulos, os cristãos, aos ramos dessa videira. E afirma a importância de eles estarem "enxertados", de estarem participando dessa árvore. Ele diz:

Permanecei em mim e eu permanecerei em vós. Como não pode o ramo
produzir fruto de si mesmo se não permanecer na videira, assim nem vós o
podeis dar se não permanecerdes em mim. ${ }^{441}$
Eu sou a videira, vós, os ramos. Quem permanece em mim e eu nele, esse dá
muito fruto, porque sem mim nada podeis fazer.

Que a graça é a presença da Trindade no ser humano - de acordo com a doutrina tomasiana -, isso fica claro no famoso episódio da conversão de Saulo, até então um temível perseguidor dos cristãos. Conforme narra o Novo Testamento, Saulo estava a caminho de Damasco, na Síria, a fim de prender os cristãos ali instalados. De repente, viu uma luz que brilhava ao seu redor. Caindo no chão, ouviu uma voz: "Saulo, Saulo, por que me persegues?”. Ele ainda perguntou: “Quem és tu, Senhor?”. E a resposta foi: "Eu sou Jesus, a quem tu persegues". 443

Certamente Saulo ficou muito confuso. Ele perseguia cristãos, homens e mulheres que se diziam seguidores de Cristo, mas não o próprio Cristo. Ao dizer "Por que me persegues?", o Verbo estava se identificando com aqueles seres humanos comuns que depositavam sua fé nele, o que demonstra claramente a presença da divindade no cristão pela graça - ou seja, a participação do cristão na natureza divina.

A partir daquele encontro, teve início o processo de filiação divina de Saulo, que se transformou no apóstolo Paulo, o missionário responsável, mais tarde, pela evangelização de boa parte do mundo conhecido. Esse processo tem como ápice a plena

\footnotetext{
${ }^{438}$ Hebreus 3:14.

${ }^{439}$ Hebreus 12:10.

${ }^{440} 2^{a}$ Pedro 1:4.

441 João $15: 4$.

442 João 15:5-6.

${ }^{443}$ Atos dos apóstolos 9:3-5.
} 
participação do cristão na vida divina, expressa por Paulo numa frase célebre, incluída numa de suas epístolas: "Vivo, não mais eu, mas Cristo vive em mim"444.

Em outra epístola, Paulo é ainda mais claro quanto aos efeitos da graça, que faz com que o ser humano participe intimamente da vida divina, de tal forma que Deus mesmo habita nele:

Acaso não sabeis que o vosso corpo é santuário do Espírito Santo, que está em vós, o qual tendes da parte de Deus, e que não sois de vós mesmos? $?^{445}$

Essa concepção da graça como participação do homem na vida divina teve poucos adeptos ao longo da história. Em geral, os principais teólogos da Igreja consideraram a graça como um "favor não merecido", que nada tinha a ver com a matéria, com o corpo, com a vida cotidiana, mas com o espírito. Um desses teólogos foi Santo Agostinho. Sua concepção da graça é assim explicada por Louis Berkhof:

\begin{abstract}
Agostinho distingue vários estágios na obra da graça divina, aos quais ele denomina de "graça preveniente", "graça operante" e, finalmente, "graça cooperadora". No primeiro estágio, o Espírito de Deus emprega a lei para produzir o senso de culpa e de pecado; no segundo, Ele usa o evangelho para produzir aquela fé em Cristo e na sua obra expiatória que floresce na justificação e na paz com Deus; e, no terceiro, a vontade renovada do homem coopera com Ele na obra de santificação, que se prolonga pela vida inteira. Inclusas na obra da graça estão a inteira renovação do homem à imagem de Deus e a transformação espiritual do pecador num santo. ${ }^{446}$
\end{abstract}

\title{
Lauand acrescenta:
}

\begin{abstract}
A teologia agostiniana, na medida em que tinha em pouco a realidade material e objetiva do mundo, tendia a considerar a graça não como uma realidade, um fato objetivo, mas como uma simples benevolência divina um "cair nas graças de Deus" - que, no homem, não corresponderia a nada de real. Tomás, pelo contrário, mesmo afirmando que o mundo é mundo; o corpo, corpo; o homem, homem, lembra que estas são realidades distintas de Deus, e que a graça não destrói nem altera essencialmente nenhuma delas, permite-nos compreender que elas são, na íntegra e completamente, assumidas por Deus e elevadas a uma realidade superior. ${ }^{447}$
\end{abstract}

Talvez porque a graça de Deus tenha sido entendida como algo externo ao cristão - e não como a presença transformadora da própria Trindade nele - , o cristianismo se tornou, em boa medida, uma religião de regras, mandamentos e proibições. Isso é bastante evidente na Igreja Católica Apostólica Romana, em que os

\footnotetext{
${ }^{444}$ Carta aos Gálatas 2:20.

$4451^{a}$ Carta aos Coríntios 6:19.

${ }^{446}$ Louis Berkhof, A história das doutrinas cristãs, tradução de João Marques Bentes e Gordon Chown, São Paulo, PES, 1992.

${ }^{447}$ Jean Lauand, Oriente e Ocidente: razão, natureza e graça - Tomás de Aquino em sentenças, São Paulo, Centro de Estudos Árabes da USP/Edix, página 31.
} 
fiéis se obrigam a cumprir uma série de preceitos para se sentir aceitos por Deus. Mas também as Igrejas protestantes - originárias de um movimento que, no século XVI, buscava exatamente reintroduzir no cristianismo a ideia da salvação pela graça de Deus, e não pelas obras humanas - têm a mesma tendência. Nelas, o comportamento predominante tende, quase imperceptivelmente, a equacionar a vida cristã, de forma que esta se transforma não no gozo da presença de Deus no cristão, mas sim na obediência a padrões de conduta racionalmente estabelecidos.

Tais posturas de católicos e protestantes se originam possivelmente na maneira equivocada de conceber a graça de Deus. Pois quando se percebe que a graça significa a participação do cristão na vida divina que é na Trindade, tudo se transforma, e o cristianismo deixa de ser uma religião de regras e proibições para se tornar um meio de obter a "vida abundante" prometida por Cristo aos cristãos ${ }^{448}$.

Ao concluir esta breve análise sobre a participação em Tomás de Aquino, podese afirmar que esse conceito tomasiano - ou, melhor dizendo, dionisiano-tomasiano - é uma originalíssima clave de interpretação da existência e uma forma de lançar novas luzes sobre a teologia e a prática cristã.

No que se refere ao mundo, ele restitui às coisas criadas a dignidade que haviam perdido por conta de séculos de predomínio de uma visão por demais espiritualista da vida, que sempre valorizou o espírito e desprezou a matéria, considerada má. Esta, afinal, é também criação de Deus e revela, ainda que de modo muito deficiente e remoto, um pouco do Criador. Além disso, o conceito oferece profundas respostas para uma das mais instigantes questões filosóficas - a origem de todas as coisas, que, como já afirmava o Sócrates platônico, não se encontra nas coisas materiais, mas no mundo supra-sensível.

Já no que diz respeito à teologia, a participação tende a conferir dignidade ao próprio cristão - constantemente induzido ao legalismo por teologias e doutrinas excessivamente racionalizadas -, visto agora como aquele que participa (que possui parte) da infinita essência divina.

A participação é, portanto, uma forma de conferir o mais alto valor às coisas criadas - a matéria, os animais, as plantas, o homem, o planeta -, que, hoje como no passado, sofrem agressões de todos os tipos (ambientais, sociais, psicológicas) e estão sempre à procura de algo que lhes resgate a dignidade.

${ }^{448}$ João 10:10: "Eu vim para que tenham vida, e vida em abundância". 


\section{DA METÁFORA COMO FONTE DO CONHECIMENTO}

Nos capítulos anteriores, analisamos dois conceitos fundamentais da filosofia de Tomás de Aquino - negatividade e participação - que, enraizados no pensamento do Pseudo Dionísio Areopagita, constituem uma clave originalíssima para o entendimento da realidade. Como vimos, a primeira constatação oferecida por esses conceitos é a de que o mundo é inapreensível ao entendimento humano. A Causa primeira das coisas onde se acha a explicação mais profunda da existência -, sendo suprarracional, encontra-se infinitamente afastada da inteligência e da imaginação do homem, numa transcendência radical, absoluta e incompreensível. Daí por que é preciso negar qualquer qualidade e característica a essa Causa, que não se confunde com nada do que existe. Pelo mesmo motivo, descobre-se a inutilidade de tentar subjugar a realidade sob a férrea lógica da razão humana, como fazem os racionalistas mais exaltados.

Ao mesmo tempo, porém, como também foi observado, as coisas criadas "falam" de alguma maneira a respeito da Causa primeira, justamente porque têm origem nela e participam dela. Para dizer com Tomás de Aquino, elas existem porque o Ser dá ser, transfere ser para que as coisas sejam. Da mesma forma como todo efeito revela algo da sua causa, o mundo criado, as coisas sensíveis - das mais simples às mais sofisticadas, seja uma pedra, um inseto, um organismo complexo ou o Universo transmitem algo do Criador, ainda que de modo "remoto e deficiente", também segundo as palavras do Aquinate.

Justamente porque a Causa de todas as coisas possui esses dois aspectos - talvez até antagônicos -, ou seja, porque essa Causa é, simultaneamente, totalmente inapreensível e parcialmente revelada, ocorre a necessidade de se falar dela utilizando um discurso distinto da insuficiente linguagem tradicional, moldada pela lógica. Ao invés de descrições que buscam aproximar as palavras o máximo possível da realidade, deve-se, ao falar das coisas suprarracionais e da essência mais íntima dos seres, usar as metáforas, as alegorias e as analogias, que podem nos conduzir com mais propriedade ao conhecimento daquilo que, afinal, é incognoscível.

É isso o que indicam o Pseudo Dionísio Areopagita e Tomás de Aquino, que, cientes da incapacidade da razão humana para conhecer o mais profundo da essência das coisas, concordam a respeito da necessidade de buscar o conhecimento através da metáfora. Para Dionísio, o homem é simplesmente incapaz de, por si mesmo, chegar ao 
conhecimento dos bens divinos, que estão muito além de seu entendimento. Para isso, é preciso que ele recorra à ajuda das coisas sensíveis, através das quais, de algum modo, alcançará as realidades espirituais. Em Da hierarquia celeste, Dionísio afirma:

\begin{abstract}
Mas as hierarquias imateriais têm se revestido de múltiplas figuras e formas materiais, a fim de que, conforme nossa maneira de ser, nos elevemos analogicamente desde esses signos sagrados à compreensão das realidades espirituais, simples, inefáveis. Nós, homens, não poderíamos de modo nenhum nos elevar por via puramente espiritual a imitar e contemplar as hierarquias celestes sem a ajuda de meios materiais que nos guiem como requer nossa natureza. ${ }^{449}$
\end{abstract}

O homem necessita que o raio divino, partindo da Causa hiper-luminosa de todos os seres, chegue acomodado ao seu modo natural e próprio de perceber as coisas, sem o que ele estaria para sempre separado dessa Causa. Daí por que a iluminação divina encontra-se velada em variadas figuras ${ }^{450}$.

Dionísio dá duas razões pelas quais é preciso que as imagens representem o que não tem figura e dêem corpo ao incorpóreo. Uma delas se refere a essa incapacidade do ser humano de se elevar diretamente à contemplação mental. "Necessitamos de algo que nos seja conatural, metáforas que sugerem as maravilhas que escapam ao nosso entendimento." 451 A outra razão diz respeito ao fato de que as metáforas servem para ocultar aos incrédulos os enigmas e as verdades sagradas que elas contêm. Ou seja, a metáfora, para Dionísio, serve tanto para revelar como esconder as realidades espirituais, que são percebidas ou ignoradas de acordo com a sensibilidade de cada um.

Percebe-se, assim, que o método usado por Deus para dar ao homem entendimento das coisas espirituais é a metáfora. Falando da linguagem figurada das Sagradas Escrituras, Dionísio diz que as alegorias e símbolos contidos nos textos do Antigo e do Novo Testamento servem para nos elevar espiritualmente desde o sensível e o conceitual até os mais altos cumes das hierarquias celestes ${ }^{452}$. "Pela matéria podemos nos elevar até os arquétipos imateriais" ${ }^{" 453}$, afirma Dionísio. Ainda se referindo aos escritores sacros, o autor de Da hierarquia celeste lembra que eles se valeram de imagens sensíveis para falar do transcendente, transmitiram o mistério da unidade por

\footnotetext{
${ }^{449}$ Da hierarquia celeste $\mathrm{I}$.

${ }^{450}$ Da hierarquia celeste I.

${ }^{451}$ Da hierarquia celeste II.

${ }^{452}$ Da hierarquia celeste I.

${ }^{453}$ Da hierarquia celeste II.
} 
meio da variedade e da multiplicidade e transformaram o divino em humano e o imaterial em material. ${ }^{454}$

Também em Dos nomes divinos, Dionísio destaca a importância de se valer de símbolos para entender as realidades divinas, tanto quanto é possível ao homem. Através deles, nos elevamos à verdade una, quando então as imagens do divino são abandonadas, pois não são mais necessárias ${ }^{455}$. Na realidade, todo o Universo e a natureza estão ordenados com o fim último de permitir que o ser humano, desde as pequenas e insignificantes imagens e exemplos, se eleve à única Causa de todas as coisas e contemple tudo o que existe unido e uniforme, até mesmo as coisas contrárias entre si, pois aquela Causa é o princípio de todas as coisas. "Mediante o conhecimento que temos das coisas somos levados, tanto quanto é possível, ao conhecimento da Causa de todas as coisas em particular.,"456

Deus não é percebido pelos sentidos nem pela inteligência humana. Ele não é nada do que existe. É impossível conhecer Deus por sua natureza, uma vez que esta é incognoscível e supera toda razão e inteligência. Como, então, podemos falar de conhecimento de Deus? Como podemos conhecê-lo, ainda que de forma parcial? A resposta a essas questões é dada por Dionísio:

Nós o conhecemos pela ordem de todas as coisas, enquanto estão dispostas por Ele mesmo e contêm em si certas imagens e semelhanças de seus exemplares divinos, pelas quais ascendemos ao conhecimento daquele sumo Bem e fim de todos os bens, por caminho acomodado a nossas forças. ${ }^{457}$

É correto utilizar a linguagem simbólica para falar de Deus, diz Dionísio, porque todas as coisas o louvam em sua relação de efeitos que são dele. A sabedoria divina é cognoscível "a partir das coisas" 458 . E, em Da teologia mística, lê-se:

As coisas mais santas e sublimes percebidas pelos nossos olhos e razão são apenas meios pelos quais podemos conhecer a presença daquele que tudo transcende. Através delas, faz-se manifesta sua inimaginável presença. ${ }^{459}$

A Carta 9 do Pseudo Dionísio Areopagita é toda dedicada a explicar a conveniência e necessidade de usar metáforas para se referir a Deus. Ela começa ressalvando que, por si mesmos, os símbolos não têm valor. Eles são apenas a parte visível através da qual a pessoa comum pode compreender o inefável e invisível.

\footnotetext{
${ }^{454}$ Da hierarquia eclesiástica $\mathrm{I}$.

${ }^{455}$ Dos nomes divinos I.

${ }^{456}$ Dos nomes divinos $\mathrm{V}$.

${ }^{457}$ Dos nomes divinos VII.

${ }^{458}$ Dos nomes divinos VII.

${ }^{459}$ Da teologia mística I.
} 
Embora possa dar a impressão de ser uma "incrível e monstruosa fantasia", a variedade de símbolos sagrados "põe de manifesto o que está oculto" e, ao mesmo tempo voltando ao tema da metáfora como velação, como forma de ocultar as coisas espirituais -, impede que os profanos abusem e escarneçam dos santos mistérios. Mas, enquanto os símbolos materiais afastam os infiéis do conhecimento de Deus, este é descoberto àqueles que de coração buscam a santidade. Somente estes, segundo Dionísio, sabem como desembaralhar os signos sagrados de seu imaginário infantil. Só eles desfrutam de mente apta e poder de contemplação para penetrar na simples, maravilhosa e transcendente verdade dos símbolos.

Existe um duplo aspecto na tradição teológica, diz Dionísio: um se refere ao que é evidente e cognoscível e outro está relacionado ao que é inefável e misterioso. O primeiro se serve da filosofia, da demonstração e do raciocínio e se vale da persuasão. Já o segundo requer o símbolo, opera misteriosamente, sem que possa ser demonstrado, e "põe as almas ferventes na presença de Deus". Segundo Dionísio, "o arcano se entrelaça com o manifesto".

A elevação do homem às realidades espirituais, através dos símbolos, é possível porque a alma, no que tem de puramente espiritual, sintoniza com o aspecto interior das imagens, com aquilo que elas têm de divino. Dionísio insiste em que é preciso se aprofundar no sentido dos símbolos sagrados, dizendo:

\footnotetext{
Não devemos menosprezá-los, porque têm sua origem nas realidades divinas e levam sua impressão. São imagens claras de espetáculos inefáveis e maravilhosos. Certamente as realidades supraessenciais, puramente intelectuais, as luzes divinas em geral adquirem visível colorido através de símbolos. ${ }^{460}$
}

A imagem do fogo, por exemplo, é uma ótima maneira de explicar através do sensível a ideia de que Deus é causa de todas as coisas e até mesmo o conceito de participação - assim como as coisas quentes participam do fogo, os seres participam do Ser, que é Deus. Já quando se fala sobre embriaguez, referindo-se a Deus ela tem o sentido não de saciedade indevida, mas de superabundância incomensurável dos bens de Deus. A imagem do Deus que dorme, por sua vez, indica que Ele é absolutamente transcendente e os seres são incapazes de se comunicar diretamente com a Causa de todas as coisas.

Na Carta 10, Dionísio escreve uma frase que se tornaria famosa: "O visível é realmente imagem do invisível".

${ }^{460}$ Carta 9. 
Já o mundo é uma grande metáfora reveladora do divino, diz Dionísio, reproduzindo e adaptando um clássico tema neoplatônico. Citando, na Carta 9, o apóstolo Paulo - que na Carta aos Romanos considera "as obras projetadas" uma expressão dos atributos invisíveis de Deus ${ }^{461}$-, o autor de Dos nomes divinos afirma que "a formosura aparente é signo de mistérios sublimes"462. Todas as coisas boas observadas na natureza, afirma ainda Dionísio, podem favorecer a contemplação ${ }^{463}$. As coisas existem como um "certo vestígio" da divina semelhança ${ }^{464}$.

Da mesma forma como o mundo visível põe de manifesto os mistérios invisíveis de Deus ${ }^{465}$, também a Igreja, com seus ritos e símbolos, é uma metáfora que desvela parcialmente o divino. A cerimônia da eucaristia, o batismo e as imagens, por exemplo, contêm profundo significado, que conduz os fiéis à contemplação do sagrado. Como afirma Dionísio:

\footnotetext{
Nossa hierarquia é por si mesma símbolo e adaptação à nossa maneira de ser. Precisa se servir de signos sensíveis para nos elevar espiritualmente às realidades do mundo. ${ }^{466}$

Os símbolos sagrados são realmente expressão sensível de realidades inteligíveis. Mostram o caminho que leva aos inteligíveis, que são o princípio e a ciência de quanto a hierarquia representa sensivelmente. ${ }^{467}$
}

Mas, apesar do acesso às realidades espirituais que oferece ao homem, a metáfora sempre permanecerá uma forma insuficiente de chegar ao conhecimento de Deus, uma vez que este é inesgotável, lembra Dionísio. Assim como não há uma perfeita semelhança entre uma causa e seus efeitos - que levam consigo a marca de suas origens somente como podem, segundo sua capacidade limitada - e uma causa sempre transcende os efeitos por sua própria natureza, também o mundo natural não pode ser comparado a Deus, que o transcende infinitamente. Daí por que Dionísio afirma que é impróprio dizer que Deus está presente em todas as coisas, pois assim "limitamos sua infinitude, que excede e contém tudo" 468 .

Reduz-se a infinitude divina também pela linguagem, que, extremamente limitada, ao utilizar termos como Deus, Vida, Ser, Luz e Verbo, indica apenas certas

\footnotetext{
461 Romanos I, 20: "Desde a criação do mundo, as coisas invisíveis dele (de Deus), como o seu eterno poder e divindade, são observadas pelas obras projetadas".

${ }^{462}$ Da hierarquia celeste I.

${ }^{463}$ Da hierarquia celeste II.

${ }^{464}$ Dos nomes divinos IX.

${ }^{465}$ Carta 9.

${ }^{466}$ Da hierarquia eclesiástica $\mathrm{I}$.

${ }^{467}$ Da hierarquia eclesiástica II.

${ }^{468}$ Dos nomes divinos III.
} 
propriedades que dimanam da fonte primordial até os seres humanos, sem chegar à essência ou à totalidade daquilo a que se refere. "A verdade é que as realidades divinas nos chegam por conhecimento indireto, por via de participação. O que são em si, em sua fonte e fundamento, escapa ao alcance do entendimento, de todo ser e conhecer."469

Essa postura de Dionísio - a incapacidade humana de conhecer as realidades espirituais; a necessidade de utilizar metáforas para falar de Deus etc. - é assumida no pensamento de Tomás de Aquino, que assimila essas ideias e lhes dá novo e original formato. Ao tratar do tema da metáfora, Tomás cita explicitamente textos de Dionísio, tornando ainda mais evidente sua filiação ao pensamento dionisiano.

Isso acontece logo no início da Suma teológica. Na questão 1, Tomás - para quem usar metáforas é "apresentar uma verdade mediante imagens" conveniente que a Bíblia se refira a Deus utilizando metáforas. Após expor três argumentos contrários a esse recurso, ele responde que "é natural ao homem elevar-se ao inteligível pelo sensível, porque todo o nosso conhecimento se origina a partir dos sentidos". Por isso, convém que nas Sagradas Escrituras as realidades espirituais nos sejam transmitidas por meio de metáforas corporais. E completa: "É o que diz Dionísio, capítulo 1 de Da hierarquia celeste: 'O raio da luz divina só pode refulgir para nós envolvido na diversidade dos véus sagrados"”.

Além disso, continua Tomás, como as Escrituras são dirigidas a todas as pessoas - cultas ou ignorantes -, é conveniente apresentar as realidades espirituais mediante imagens corporais, a fim de que as pessoas simples, que "não estão aptas a apreender por si mesmas as realidades inteligíveis", possam compreendê-las. Nas objeções aos argumentos contrários ao uso das metáforas pela Bíblia, ele afirma que a doutrina sagrada utiliza esse recurso por necessidade e utilidade - ou seja, a fim de ser entendida por todos - e não simplesmente para sugerir uma representação deleitável ao homem, como ocorre na poesia.

A respeito da ideia de que a metáfora esconde a verdade, Tomás cita Dionísio novamente. Afirma que, “diz Dionísio”, o fulgor da divina revelação não é suprimido pelas figuras sensíveis que o velam. Antes, permanece em sua verdade, de modo a impedir que mentes às quais é feita a revelação se limitem às imagens. "Ele as eleva até o conhecimento das coisas inteligíveis e, por seu intermédio, os outros são igualmente instruídos." A obscuridade das imagens é até mesmo útil, tanto para exercitar os

\footnotetext{
${ }^{469}$ Dos nomes divinos II.

${ }^{470}$ Suma teológica I, I, 9.
} 
estudiosos como para evitar as zombarias dos infieis, acrescenta Tomás, reproduzindo outra noção de Dionísio - a de que a metáfora serve também para esconder as realidades espirituais e livrá-las do escárnio dos zombadores.

Finalmente, em resposta ao argumento de que Deus deve ser referido através das criaturas mais nobres e sublimes - e não das mais ínfimas, como acontece com a metáfora -, Tomás volta a se referir ao autor de Da hierarquia celeste:

\begin{abstract}
Dionísio explica por que nas Escrituras é preferível que as coisas divinas sejam apresentadas sob a figura dos corpos mais vis, e não dos mais nobres. Dá três razões para isso. Em primeiro lugar, desse modo afasta-se mais o espírito humano do erro. Fica claro que essas coisas não se aplicam com propriedade às coisas divinas: o que poderia provocar dúvidas se estas fossem apresentadas sob a figura dos corpos mais nobres, sobretudo para os seres humanos que nada imaginam de mais nobre do que o mundo corporal. Em segundo lugar, essa maneira de agir se encontra em maior conformidade com o conhecimento que alcançamos de Deus nesta vida, porque de Deus sabemos mais o que Ele não é do que o que é. Assim, as semelhanças mais distantes de Deus nos levam a melhor compreender que Ele está acima de tudo o que podemos dizer ou pensar a seu respeito. Enfim, graças a esse caminho, as coisas divinas aparecem mais bem veladas aos indignos. ${ }^{471}$
\end{abstract}

Na questão 12 do mesmo livro I da Suma teológica, que discute se é possível conhecer Deus pela razão natural, Tomás oferece um importante argumento a favor do uso das metáforas e analogias para entender as coisas divinas. Ele afirma que, uma vez que nosso conhecimento natural se origina nos sentidos, esse conhecimento só poderá chegar até onde pode ser conduzido pelos objetos sensíveis. A partir daí, não há possibilidade de alcançar a visão da essência divina, pois as criaturas sensíveis são efeitos de Deus que não se igualam ao poder da causa. Mas, embora não possamos conhecer todo o poder de Deus através das coisas sensíveis, estas - uma vez que são efeitos que dependem da causa - podem pelo menos nos conduzir a conhecer de Deus "se é" e a conhecer aquilo que é necessário que lhe convenha como causa primeira universal. Assim, é possível conhecer a relação entre Deus e as criaturas, ou seja, que é causa de todas elas, e a diferença que há entre as criaturas e Deus, que não é nada do que são seus efeitos.

Em resposta à argumentação exposta no início do artigo, Tomás, depois de considerar que a razão não pode captar a forma simples ao máximo que é Deus, afirma que "deve-se dizer que Deus é conhecido naturalmente por meio das representações imaginativas de seus efeitos". Ou seja, os efeitos da Causa primeira permitem a formulação de metáforas e analogias que conduzem o homem à ciência de Deus, que de

${ }^{471}$ Suma teológica I, 9, ad 3. 
outra forma é inacessível, visto que o conhecimento humano só chega aonde os objetos sensíveis alcançam.

Em outras passagens de sua vasta obra, Tomás discute se os nomes atribuídos a Deus são unívocos ou equívocos ${ }^{472}$. Ou seja, trata-se de saber como se pode falar adequadamente sobre Deus.

Para o autor da Suma teológica, os nomes atribuídos a Deus e aos outros entes não são nem totalmente unívocos nem totalmente equívocos. Não se pode dizer que são unívocos porque a definição do que se diz da criatura não é a definição do que se diz de Deus, e os nomes unívocos precisam ter a mesma definição. Também não são de todo equívocos porque, nos casos equívocos, os nomes são atribuídos a uma coisa sem nenhuma referência a outra, mas, no que se refere a Deus e às outras coisas, os nomes são atribuídos a Deus segundo uma certa relação que Ele tem com essas coisas, de forma que, conhecendo-as, pode-se raciocinar a respeito do divino.

Portanto, diz Tomás, os nomes são atribuídos a Deus não univocamente ou equivocamente, mas segundo a analogia, ou seja, segundo a relação que têm a uma mesma coisa. Ele afirma:

Quando nós colocamos a coisa em relação a Deus como à sua origem primeira, os nomes que significam a perfeição das coisas são atribuídas a Deus. Disso resulta com evidencia que, embora quanto à imposição do nome esses nomes se dizem antes de tudo das criaturas (...); todavia, se se olha para a realidade significada do nome, os nomes se dizem antes de tudo de Deus, do qual descem as perfeições nas outras coisas. ${ }^{473}$

Na Questão Disputada De Potentia, Tomás aborda o mesmo tema. Ali, ele afirma que é impossível alguma coisa ser predicada univocamente de Deus e das criaturas. Isso porque qualquer efeito de um agente unívoco igualaria a capacidade do agente. Mas nenhuma criatura, sendo finita, pode igualar a capacidade do primeiro agente, que é infinita. "Por isso, é impossível que a semelhança com Deus seja recebida na criatura univocamente." 474

É evidente - continua Tomás - que, embora seja única a noção da forma existente no agente e no efeito, o seu diverso modo de existir impede a predicação unívoca. Por exemplo, embora a noção de casa que existe na matéria e na mente do

\footnotetext{
${ }^{472}$ Nome unívoco é aquele que expressa um significado absolutamente idêntico a respeito dos diversos sujeitos dos quais se predica. Por exemplo, quando se diz "homem", em referência a Pedro, Paulo e João. Nome equívoco é aquele que indica um significado absolutamente diverso entre os sujeitos dos quais se predica, como ao falar "manga", que pode tanto ser uma fruta como uma parte do vestuário.

${ }^{473}$ Compêndio de teologia, 27.

${ }^{474}$ De Potentia, questão 7, artigo 7.
} 
arquiteto seja a mesma, a casa não é predicada univocamente de ambos, pois a espécie da casa na matéria tem um ser material, enquanto na mente do artista possui um ser imaterial.

Mas também não se fala de Deus de maneira equívoca, repete Tomás. Uma vez que todo o conhecimento que o homem possui de Deus vem das criaturas, se estas fossem comuns a Deus apenas pelo nome, não se saberia nada a respeito do divino, exceto expressões vãs a que nada corresponderia na realidade. Além disso, todas as demonstrações dos filósofos acerca de Deus seriam meros sofismas.

É necessário que o efeito seja de algum modo similar à causa; por isso, nada é predicado de modo puramente equívoco da causa e do efeito, como se diz da medicina e do animal. ${ }^{475}$

E Tomás completa:

Deve-se adotar, portanto, uma outra opinião, pois de Deus nada vem dito de modo puramente unívoco; e todavia o que é dito comumente não é predicado nem em modo puramente equívoco, e sim em modo análogo.

Essa predicação, de que fala Tomás, pode ter duas formas. Uma delas se dá quando um nome é predicado de duas coisas com relação a uma terceira. A outra forma ocorre quando um nome é predicado de duas coisas em relação uma à outra. No primeiro caso, é necessário que haja algo anterior às duas coisas a que se refere o nome, a que ambas estão relacionadas. No segundo caso, não há nada anterior, sendo necessário que um proceda do outro. Como nada precede Deus, que precede toda criatura, é esse segundo modo de predicação que deve ser aplicado a Ele. ${ }^{476}$

Basta um rápido percurso pela Bíblia para perceber que as metáforas, alegorias e analogias parecem ser a principal maneira como o divino se comunica com o humano. Tanto que levou um estudioso do assunto como Herbert Lockyer a afirmar que "em todo o âmbito literário não há livro mais rico em material alegórico e em parábolas do que a Bíblia" ${ }^{\text {477. }}$.

Nas Escrituras hebraicas as metáforas são abundantes, sempre a serviço de revelar algum traço de Deus, uma realidade espiritual ou uma dimensão da vida humana. Nelas, Deus é comparado a uma rocha, a uma cidadela fortificada, a um escudo $^{478}$, para dar a ideia da proteção que Ele dispensa. A mais profunda aspiração da

\footnotetext{
475 De Potentia, questão 7, artigo 7.

${ }^{476}$ De Potentia, questão 7, artigo 7.

${ }^{477}$ Herbert Lockyer, Todas as parábolas da Bíblia. São Paulo: Vida, 2006, página 7.

${ }^{478}$ Salmo 18:2-3.
} 
alma - a contemplação do divino - é comparada a uma corça sedenta ${ }^{479}$ e a uma "terra árida, exausta, sem água" ${ }^{480}$. Para lembrar ao homem que deve louvar o Criador, o salmista sugere essa atitude aos elementos da natureza: "Alegrem-se os céus e a terra exulte, ruja o mar e a sua plenitude. Folgue o campo e tudo o que nele há; regozijem-se todas as árvores do bosque" ${ }^{, 481}$.

Conselhos práticos também são dados com a ajuda de metáforas. A prostituta deve ser evitada porque seu fim é "amargo como o absinto, agudo como a espada de dois gumes" ${ }^{\prime 42}$. Aceitar ser fiador de outrem é o mesmo que a gazela cair no laço do caçador e a ave, na mão do passarinheiro ${ }^{483}$. O preguiçoso precisa considerar a formiga, que trabalha sem descanso, a fim de escapar da ruína ${ }^{484}$.

Mas não são somente os chamados livros poéticos das Escrituras hebraicas que falam em parábolas e alegorias, como se poderia supor. Os mesmos recursos estão presentes no Pentateuco, nos livros históricos e nos livros proféticos. A começar pelos símbolos que Deus mesmo entregou ao povo hebreu: da circuncisão - sinal da aliança feita com Abraão ${ }^{485}$ - à Páscoa ${ }^{486}$, que representa a libertação em relação ao Egito, todas as cerimônias religiosas do culto hebraico são representações metafóricas de grandes verdades acerca de Deus e de seu relacionamento com os homens.

No livro de Juízes, é narrado um discurso feito por Jotão ao povo de Siquém, que havia sido persuadido por Abimeleque, filho bastardo de Gideão, a matar todos os 70 filhos legítimos de Gideão e proclamá-lo rei. Do massacre, somente Jotão escapara e, do alto do monte Gerizim, contou aos siquemitas a parábola das árvores ${ }^{487}$. Disse que as árvores quiseram ungir um rei para si e pediram que a oliveira reinasse, mas esta recusou o posto. As árvores pediram o mesmo para a figueira, que também se recusou a reinar, e depois para a videira, com o mesmo resultado. Então, as árvores foram ao espinheiro, que disse: “Se, deveras, me ungis rei sobre vós, vinde e refugiai-vos debaixo de minha sombra; mas, se não, saia do espinheiro fogo que consuma os cedros do Líbano”. Seja uma parábola ou uma fábula, como é disputado entre os especialistas ${ }^{488}$,

\footnotetext{
${ }^{479}$ Salmo 42:1.

${ }^{480}$ Salmo 63:1.

${ }^{481}$ Salmo 96:11-12.

${ }^{482}$ Provérbios 5:4.

${ }^{483}$ Provérbios 6:5.

${ }^{484}$ Provérbios 6:6-11.

${ }^{485}$ Gênesis 17:10.

${ }^{486}$ Êxodo $12: 1-28$.

${ }^{487}$ Juízes 9:7-15.

${ }^{488}$ Uma disputa talvez estéril, tendo em vista que o hebraico mashal se aplica a ambas as expressões.
} 
esse texto pode ser interpretado como se as árvores fossem o povo de Siquém, que se recusavam a ter Deus como rei e desejavam um líder visível. O espinheiro seria o próprio Abimeleque, com as desastrosas consequências que seu reinado traria para aquele povo.

O pecado de Davi, que enviara Urias para a morte a fim de desposar a mulher deste, Bate-Seba, foi anunciado ao rei pelo profeta Natã através de uma parábola. Enviado por Deus, Natã disse a Davi que um homem rico possuía muitas ovelhas e gado, enquanto um homem pobre tinha apenas uma cordeira, que estimava como a uma filha. Um dia, o homem rico, ao invés de matar um de seus inúmeros animais para dar de comer a um viajante recém-chegado, tomou a única cordeira do homem pobre e a preparou para o visitante. Davi se enfureceu com a história e ordenou que quem tivesse cometido algo semelhante deveria morrer. Foi quando Natã revelou que havia sido ele mesmo, o próprio rei Davi, quem se comportara como o homem rico, ao tomar a esposa de Urias.

Nos textos do profeta Isaías, prevalecem as metáforas e alegorias que tratam da relação do povo de Israel com Deus. Isaías afirma que o boi conhece o seu possuidor e o jumento sabe quem é o dono da sua manjedoura, mas Israel não tem entendimento ${ }^{489}$. Para mostrar que a antiga nação hebraica, afastada de Deus, estava sem direção, o profeta a compara a uma terra assolada, a cidades consumidas pelo fogo, a lavouras que os estranhos devoram ${ }^{490}$. Mesmo assim, o perdão de Deus está ao seu alcance e, se ele for aceito, os pecados do povo, ainda que sejam como a escarlata, se tornarão brancos como a neve ${ }^{491}$.

Com os textos sagrados cristãos não acontece diferente. Também neles predominam a linguagem figurada, a metáfora, a analogia - e nunca o raciocínio dedutivo, a tentativa de "entender" racionalmente as realidades espirituais. Jesus mesmo se define como "o bom pastor" ${ }^{492}$, "a videira verdadeira"493, "a porta",494, "o pão da vida"495, "o caminho, a verdade e a vida" ${ }^{496}$. O reino de Deus é comparado a um tesouro escondido no campo ${ }^{497}$, a uma pérola ${ }^{498}$, a uma rede de pesca $^{499}$, a um grão de

\footnotetext{
${ }^{489}$ Isaías 1:3.

${ }^{490}$ Isaías 1:7.

${ }^{491}$ Isaías 1:18.

492 João 10:11.

493 João 15:1.

${ }^{494}$ João 10:7.

495 João 6:35.

496 João 14:6.

${ }^{497}$ Mateus 13:44.
} 
$\operatorname{mostarda}^{500}$. Profundas mensagens espirituais são ensinadas por meio de singelas parábolas, como a do credor incompassivo ${ }^{501}$ - que confronta as pequenas dívidas entre os homens com a infinita dívida dos seres humanos para com Deus - e a do filho pródigo $^{502}$, que fala do amor incomensurável de Deus pelo arrependido. Todo o que ouve as palavras de Jesus e as pratica é comparado a um homem que construiu sua casa sobre a rocha, que permanece em pé mesmo que seja atingida por uma enchente, porque está bem construída ${ }^{503}$.

Ao reinterpretar as Escrituras hebraicas, os cristãos ampliaram a visão metafórica de várias passagens do Velho Testamento, venda-as como prenúncio da vinda de Cristo ao mundo. Lockyer, seguindo a tradição, classifica como parábola da Redenção, por exemplo, o episódio em que Abraão oferece seu filho Isaque a Deus, narrado no capítulo 22 de Gênesis. Lembrando que o autor da Carta aos Hebreus afirma que, depois do ato de obediência de Abraão, Deus "em figura o recobrou" (Hebreus $11: 19)^{504}$, Lockyer destaca que o ato de depositar Isaque sobre o altar é uma representação parabólica da morte - parábola em gestos, não em palavras -, e sua libertação foi, portanto, uma representação da ressurreição de Cristo. "É interessante observar que Isaque é o único nas Escrituras, além de Jesus, a ser chamado "unigênito"”, aponta Lockyer. "Essa narrativa é uma figura impressionante da oferta do Filho unigênito de Deus, que foi por escolha própria entregue 'por todos nós' (Romanos 8:32) e foi recebido de entre os mortos pelo Pai ( $1^{a}$ Timóteo 3:16)."

O apóstolo Paulo, citando a lei mosaica, que exarava "Não atarás a boca ao boi, quando pisa o trigo", pergunta, enfatizando o caráter metafórico dessa norma: “Acaso é com bois que Deus se preocupa? Ou é seguramente por nós que Ele o diz?"

O tabernáculo erigido por Moisés no deserto constitui também parábola de uma herança ainda mais gloriosa, continua Lockyer, citando novamente a Carta aos Hebreus, que, referindo-se àquele tabernáculo, afirma: "É isto uma parábola para a época presente" (Hebreus 9:9). Os sacrifícios, as ofertas, as festas e a construção do

\footnotetext{
${ }^{498}$ Mateus 13:45-46.

${ }^{499}$ Mateus 13:47.

${ }^{500}$ Lucas 13:18-19.

${ }^{501}$ Mateus 18:23-35.

${ }^{502}$ Lucas 15:11-32.

${ }^{503}$ Lucas 6:46-49.

${ }^{504}$ Nesse versículo, a palavra traduzida por "em figura” é $\mathcal{N} \pi \alpha \rho \alpha \beta o \lambda \approx$ ("em parábola”).

${ }^{505}$ H. Lockyer, obra citada, p. 30.

${ }^{506} 1^{a}$ Coríntios 9:9-10.
} 
tabernáculo ilustram a pessoa e a obra do Redentor, bem como as bênçãos e os privilégios dos remidos, acrescenta Lockyer, que completa:

A principal característica do tabernáculo estava na sua divisão em três partes - a unidade da trindade: o átrio, com o altar do holocausto e a pia de bronze; o Santo Lugar, com a mesa dos pães da proposição, o candelabro de ouro e o altar do incenso; e o Santo dos Santos, com a arca da aliança sobre a qual estava o propiciatório. Nem precisa muita imaginação para vermos, nessas características expressas, uma parábola sobre a obra de Cristo na ordem em que se deu, desde o seu sacrifício vicário na cruz até a descida do Espírito Santo regenerador e santificador, passando por toda a sua jornada como Luz do mundo, Pão da vida e nosso Intercessor além do véu, na presença de Deus.

Talvez a mais original releitura cristã dos textos hebraicos tenha sido a dedicada ao Cântico dos cânticos, o célebre livro atribuído a Salomão que fala do amor entre um homem e uma mulher. Com cenas de erotismo explícito - "Os meneios dos teus quadris são como colares trabalhados por mãos de artista. O teu umbigo é taça redonda, a que não falta bebida; o teu ventre é monte de trigo, cercado de lírios. Os teus dois seios, como duas crias, gêmeas de uma gazela"507 -, chegou a ser considerado por muitos intérpretes impróprio para figurar entre os textos canônicos da Bíblia. O que o salvou desse destino menos nobre foi justamente o seu caráter metafórico, que revela - ou esconde... -, para os cristãos, a ideia do relacionamento entre Cristo e sua esposa, a Igreja, que será resgatada no final dos tempos. Nesse sentido se explica o pedido ansioso da mulher, no final do livro:

Vem depressa, amado meu, faze-te semelhante ao gamo ou ao filho da gazela, que saltam sobre os montes aromáticos. ${ }^{508}$

Note-se que outra grande religião monoteísta - o islamismo - defende o mesmíssimo ponto de vista: somente em parábolas, alegorias, metáforas e símbolos é possível falar do divino. O Alcorão alerta que Allah estabeleceu sinais através dos quais se comunica com os seres humanos. Esses sinais estão, por exemplo, na natureza, como se depreende dos seguintes versículos:

Por certo, na criação dos céus e da terra, e na alternância da noite e do dia, há sinais para os dotados de discernimento. ${ }^{509}$

Ele faz descer água do céu, e ela flui em vales, conforme a medida destes, então, a torrente carrega uma espuma flutuante. E, parte daquilo sob a qual acendem o fogo, para fazer jóias ou utensílios, é espuma igual. Assim, Allah apresenta em parábola a verdade e a falsidade. Quanto à espuma, vai-se

\footnotetext{
${ }^{507}$ Cântico dos cânticos 7:1-3.

${ }^{508}$ Cântico dos cânticos 8:14.

${ }^{509}$ Alcorão 3:190.
} 
embora. E, quanto ao que beneficia aos homens, permanece na terra. Assim, Allah propõe os exemplos. ${ }^{510}$

Até os menores seres são usados como fonte do conhecimento de Allah:

Por certo, Allah não se peja de propor um exemplo qualquer, seja de um mosquito ou de algo superior a este. ${ }^{5}$

A julgar pela forma metafórica de falar do divino dessas três grandes tradições religiosas - a hebraica, a cristã e a islâmica -, pode-se dizer que a metáfora está no centro mesmo do que Jean Lauand chama de "pedagogia de Deus",512.

Lauand lembra que, na cultura semita, o provérbio, a parábola, a metáfora, o exemplo - os meios como Deus ensina os homens, todos eles compreendidos na mesma expressão árabe mathal (plural: amthal) ou na hebraica mashal (plural: mashalim) servem, ao mesmo tempo, para esclarecer os fiéis e para ocultar verdades espirituais aos que insistem em recusar o caminho divino. Isso fica claro nos Evangelhos. Em Mateus, ora a parábola serve para encobrir um ensinamento - como quando Jesus diz aos seus discípulos: "Por isso lhes falo por parábolas, porque vendo, não vêem e ouvindo, não ouvem nem entendem" ${ }^{, 513}$-, ora concorre para fazer revelações, como nesta passagem: “Todas essas coisas disse Jesus às multidões por parábolas e sem parábolas nada lhes dizia; para que se cumprisse o que foi dito por intermédio do profeta: 'Abrirei em parábolas a minha boca; publicarei coisas ocultas desde a criação",514 .

A mesma dupla função da parábola surge no Alcorão, nota Lauand. O texto completo do já citado versículo 26 da sura 2, diz:

\begin{abstract}
Por certo, Allah não se peja de propor um exemplo qualquer, seja de um mosquito ou de algo superior a este. Então, quanto aos que crêem, eles sabem que ele é a verdade de seu Senhor. E, quanto aos que renegam a fé, dizem: "Que deseja Allah com este exemplo?". Com ele, Allah descaminha a muitos e, com ele, guia a muitos. E não descaminha, com ele, senão os perversos. ${ }^{515}$
\end{abstract}

Para Lauand, o sentido dos amthal de Cristo não se mede pelo seu atrativo poético nem pela sua eficácia pedagógica. A forma externa simples da parábola pode distrair o leitor de uma outra "leitura", mais profunda. Mas é precisamente esse outro nível - continua Lauand -, o da manifestação de Deus, o que interessa a Cristo, da

\footnotetext{
${ }^{510}$ Alcorão 13:17.

511 Alcorão 2:26.

512 Jean Lauand, "A pedagogia de Deus: mathal no Alcorão e na Bíblia”, Notandum 19 (janeiro-abril de 2009), Cemoroc-Feusp/IJI-Universidade do Porto).

${ }^{513}$ Mateus 13:13.

${ }^{514}$ Mateus 13:34-35.

515 Alcorão 2,26.
} 
mesma forma como Ele não cura doentes meramente para obter resultados médicos, e sim para anunciar a vinda do Reino de Deus. E quando o ouvinte não capta a realidade de Deus e de sua obra, a parábola é inócuo para ele:

Tal captação depende, em última instância, das disposições interiores: para aquele que não quer crer, a parábola, precisamente por sua forma literária, obstrui o caminho da compreensão do sentido espiritual; já para os corações simples e bem dispostos, os amthal são revelação ("A vós foi dado conhecer o mistério do Reino de Deus"). No próprio Jesus que, como Verbo encarnado, é Ele mesmo um mathal, muitos não viam senão um mero homem, o "filho do carpinteiro". ${ }^{516}$

Acrescente-se que Deus, ao falar pela boca do profeta Oseias (ele mesmo um mashal), anunciou essa sua pedagogia fundamentada na parábola, na alegoria, nos exemplos:

Falei aos profetas e multipliquei as visões; e, pelo ministério dos profetas, propus símiles. ${ }^{517}$

É curioso notar que o intelecto humano parece mesmo inclinado para a metáfora. Explique-se. Para Tomás de Aquino, o ser humano, por ter um corpo material unido a uma alma espiritual, situa-se como que no limite entre o mundo sensível e as realidades espirituais. O Aquinate explica essa estrutura ontológica do homem neste trecho fundamental da Suma contra os gentios:

\begin{abstract}
Sempre se verifica o fato de que o ínfimo de uma ordem de ser superior é limítrofe ao supremo da ordem inferior. Assim, certos ínfimos do gênero animal mal superam a vida das plantas, como é o caso da ostra, que é imóvel, só tem tato e está fixa como as plantas. Daí que S. Dionísio diga que 'a sabedoria divina enlaçou os fins dos superiores com os princípios dos inferiores'. No âmbito corporal há também algo, o corpo humano, harmoniosamente disposto, que também se enlaça com o ínfimo do superior, a alma humana, que está no último grau das realidades espirituais. Tal enlace manifesta-se no próprio modo de conhecer da inteligência humana. Daí que a alma espiritual humana seja como que um certo horizonte e fronteira entre as realidades corporais e as incorpóreas: ela mesma é incorpórea e, no entanto, é forma do corpo. ${ }^{518}$
\end{abstract}

Comentando essa passagem, Lauand ${ }^{519}$ afirma que precisamente a afirmação de que a alma é a forma do corpo constitui uma declaração de profunda unidade entre o espiritual e o material, no ser humano, e unidade entre o intelectual e o sensível, no conhecimento. Acontece que a unidade da filosofia de Tomás se manifesta não só ao

\footnotetext{
516 Jean Lauand, “A pedagogia de Deus: mathal no Alcorão e na Bíblia”.

517 Oseias $12: 10$.

${ }^{518}$ Suma contra os gentios 2,68. Tradução de Jean Lauand.

519 Jean Lauand, Provérbios e educação moral - A filosofia de Tomás de Aquino e a pedagogia árabe do mathal. São Paulo: Hottopos, 1997.
} 
tratar da constituição fundamental do homem, em que se dá a integração de espírito e matéria, mas também no que se refere às operações da alma, como o conhecimento.

O ser humano não opera diretamente pela alma, mas por meio das potências da alma, diz Tomás, seguindo Aristóteles ${ }^{520}$. O homem vê uma árvore, por exemplo, não por meio da alma, mas por meio de uma de suas potências, a visão. Da mesma forma, captam-se aromas pelo olfato. Assim, cada potência da alma está relacionada a seu objeto próprio, de forma que a potência auditiva não capta cores, mas sons, nem a potência visual atua sobre aromas, mas sim sobre imagens.

No caso da potência espiritual da alma chamada intelecto, a questão é mais complexa. Para Tomás, o intelecto pode conhecer "todas as coisas", ou seja, é capaz de uma abertura sem limites para o real - o que corresponde à clássica definição de espírito, que remonta a Platão e Aristóteles -, como ele afirma em diferentes partes de sua obra:

\begin{abstract}
As naturezas intelectuais, porém, têm maior afinidade com o todo do que as outras naturezas; pois uma substância intelectual qualquer é, de certo modo, todas as coisas, já que pode apreender a totalidade do real pelo seu intelecto; ao passo que qualquer outra substância participa apenas de um setor particular do ser. ${ }^{21}$
\end{abstract}

Diz-se que a alma é de certo modo todas as coisas, porque é naturalmente apta para conhecer tudo. E, desse modo, é possível que num único ente esteja toda a perfeição do universo. Daí que esta seja, segundo os filósofos (pagãos), a plenitude de perfeição a que a alma pode aspirar: reproduzir em si a ordem do universo como um todo e suas causas. ${ }^{522}$

A alma espiritual está essencialmente disposta a se relacionar com todos os entes $^{523}$

O ser espiritual é capaz de apreender a totalidade do real. ${ }^{54}$

Essa "abertura para o todo" da existência, de que a alma é capaz, se faz a partir do sensível, da experiência. Partindo das coisas sensíveis, o homem pode chegar ao conhecimento das essências, das realidades imateriais. É o que Tomás quer dizer ao afirmar, na citada passagem da Suma contra os gentios, que o enlace entre espírito e matéria, no ser humano, se manifesta "no próprio modo de conhecer da inteligência

\footnotetext{
${ }^{520}$ Aristóteles afirma que a alma "é o ato primeiro do corpo físico organizado que tem vida em potência" (II De Anima I, 230) e "pelo que primeiro vivemos, sentimos, nos movimentamos e inteligimos (II De Anima 4 273).

${ }^{521}$ Suma contra os gentios 3,112 .

${ }_{522}$ De Veritate 2,2. Tradução de Jean Lauand.

${ }_{523}^{523}$ Suma contra os gentios III,112.

${ }^{524}$ De Veritate $1,1$.
} 
humana", que é uma inteligência espiritual integrada ao sensível, como explica Lauand $^{525}$. Nesse sentido, o Aquinate afirma explicitamente:

É conatural ao homem atingir o conhecimento do inteligível pelo sensível. E é pelo signo que se atinge o conhecimento de alguma outra coisa. ${ }^{526}$

Todo conhecimento tem, para nós, origem no sensível. ${ }^{527}$

Justamente essa apreensão do inteligível através do sensível é o "objeto próprio" do intelecto, assim como a imagem é o objeto próprio da visão e o som é o objeto próprio da audição. Em outras palavras, "próprio da inteligência humana - potência de uma forma ordenada à matéria - é atingir a essência a partir da sensação: seu objeto próprio são as essências das coisas sensíveis", como diz Lauand, citando uma passagem fundamental da Suma teológica:

O intelecto humano, porém, que está acoplado ao corpo, tem por objeto próprio: a essência, a natureza das coisas existentes corporalmente na matéria. E mediante a natureza das coisas visíveis, ascende a algum conhecimento das invisíveis". ${ }^{528}$

Em outros trechos da obra do Aquinate tem-se a mesma ideia:

Ora, tudo o que nesta vida conhecemos é conhecido por comparação com as coisas sensíveis naturais. ${ }^{529}$

Conhecemos as realidades incorpóreas, das que não possuímos imagens, por comparação com os corpos sensíveis, dos que possuímos imagens. ${ }^{530}$

Para Tomás, o pensamento de um homem está oculto para os outros homens. Por isso, é necessário, para a manifestação do pensamento, a mediação do signo sensível. "Daí que também, quando queremos fazer alguém entender algo, propomos-lhe exempla", afirma o Aquinate, usando um termo que pode ser traduzido por "exemplos", “comparações”, “fábulas”, "parábolas” e "metáforas”, entre tantas outras expressões.

Portanto, uma vez que todo conhecimento tem origem no sensível e tendo em vista que o objeto próprio do intelecto é chegar à essência através da sensação, pode-se mesmo dizer que o intelecto está como que inclinado para a metáfora, já que esta é o meio mais adequado de atingir seu objeto próprio.

\footnotetext{
${ }^{525}$ Provérbios e educação moral, p. 72.

${ }^{526}$ III, 60, 4.

${ }^{527}$ I, 1,9 .

${ }^{528}$ Suma teológica I,84,7.

${ }^{529} \mathrm{I}, 84,8$.

${ }^{530} \mathrm{I}, 84,8$, ad 3.
} 
Essa inclinação é reforçada pela existência de um sentido interno associado à razão que Tomás chama de vis cogitativa. Tomás atribui a esse sentido a função de intermediar a passagem do conhecimento sensível para o intelectual. Como também mostra Lauand ${ }^{531}$, a cogitativa age sobre uma série de impressões sensíveis, realizando uma "pré-abstração": a collatio. Antes de o conceito se formar no intelecto, a collatio é a ordenação, agrupamento e comparação dessas sensações, como que se preparando para a abstração. "Pela collatio, a cogitativa volta-se para a massa informe de sensações, ordena-as e apresenta-as ao intelecto com o fim de descobrir a lei ou o princípio comum que as rege e que está neles latente", diz Lauand, citando novamente uma importante passagem do Aquinate a esse respeito:

Pois a experiência é resultado da comparação de muitos singulares retidos na memória. Ora, essa comparação é própria do homem e pertence à cogitativa, chamada de razão particular, porque realiza a comparação das intenções particulares, como a razão universal o faz para as intenções universais. ${ }^{532}$

Para esclarecer o significado de collatio, Lauand dá como exemplo o surgimento do conceito de kitsch. Antes de surgir esse conceito - e a palavra correspondente a ele -, a razão humana, através da collatio, agrupa e compara impressões aparentemente tão diversas como um pinguim sobre a geladeira, uma caneta de múltiplos usos e um anãozinho de jardim. "Só a partir dessa ação da cogitativa, o intelecto pode radiografar a ratio comum - latente a cada elemento dessa série de sensações - e chegar, no caso, ao conceito (e à palavra) kitsch., ${ }^{, 53}$

Não é preciso muito esforço para perceber a importância desse sentido da razão para a produção de conhecimentos sobre Deus. A imensa variedade do mundo material pode ser usado pela vis cogitativa para, através de impressões sensíveis e comparações, chegar à apreensão de realidades abstratas - ainda mais que, como vimos no capítulo anterior, todas as coisas participam daquela Causa que está acima do sensível.

Com base no que o Aquinate afirma sobre a possibilidade do conhecimento - só acessível por meio das coisas sensíveis -, pode-se também afirmar, talvez, que o sentido metafórico está presente na linguagem de modo muito mais profundo do que normalmente se supõe. Basta tomar quase aleatoriamente algumas palavras para se constatar essa afirmação. Por exemplo, num curioso artigo publicado em $1990^{534}$,

\footnotetext{
${ }^{531}$ Provérbios e educação moral, p. 88.

${ }^{532}$ In I Metaph., 1,15.

${ }^{533}$ Jean Lauand, obra citada, p. 89.

534 Alfredo Alves, "Board", in Jean Lauand, Filosofia e linguagem comum. Curitiba: Champagnat, 1990, p. 23-26.
} 
Alfredo Alves cita um caso na sua língua materna, o inglês, em que o sentido de uma palavra se amplia a partir do seu significado primário, tendo origem na realidade concreta e chegando a se tornar uma abstração. Trata-se da palavra board, que significa um pedaço de madeira estreito e longo, com espessura menor do que a de uma prancha.

Como mostra Alves, essa palavra passou a ter vários outros significados. Uma board em posição horizontal, com quatro pernas fixadas em sua parte inferior, torna-se uma mesa, e daí surgiram expressões como above board ("abertamente", "jogo limpo") e sweep the board ("limpar", ganhar todas as fichas de apostas). Board também quer dizer mesa de refeições e isso estendeu seu significado para "comida", em expressões como bed and board e board and lodging ("cama e mesa"). A denominação de um grupo de pessoas reunidas em conselho - à mesa - para deliberar sobre assuntos importantes tem essa mesma origem, como Board of Trade (Câmara de Comércio) e Electricity Board (a diretoria da empresa de eletricidade).

Nesse breve exemplo, pode-se perceber como a linguagem utilizada pelo homem comum, no seu dia a dia, está mais impregnada de metáforas. Praticamente todas as palavras que se utilizam remetem ao concreto, origem de seu significado primário, para depois se desdobrar em tantos outros significados, cada vez mais distantes de seu sentido inicial.

Talvez a dificuldade do homem ocidental para compreender a importância da metáfora resida na sua forma de pensamento, tão voltada para a explicação lógicoracional das coisas, diferente da forma de pensamento de outros povos, como os semitas, que se servem com muita naturalidade do discurso simbólico e figurado. Essa diferença entre formas de pensamento - que poderia explicar os distintos meios de se relacionar com a realidade - foi destacada pelo filósofo alemão Johannes Lohmann ${ }^{535}$.

Segundo ele, a estrutura linguística de um povo determina o seu modo de pensar e de entender o mundo. Lohmann designa o sistema linguístico indo-europeu, que deu origem às línguas ocidentais modernas, com o termo grego logos, enquanto o sistema árabe é chamado de ma'na (intencionalidade). O sistema logos busca estabelecer uma exata correspondência entre o pensamento e a realidade e chegar à essência daquilo que é dito. Isso é favorecido pelo fato de que tal sistema está centrado no verbo esti (ser) e na flexão de temas - e não de raízes das palavras. Já o sistema ma’na não está voltado

\footnotetext{
${ }^{535}$ Johannes Lohmann, "Santo Tomás e os árabes - Estruturas linguísticas e formas de pensamento", in Revista de Estudos Árabes, São Paulo: Centro de Estudos Árabes da Faculdade de Filosofia, Letras e Ciências Humanas (FFLCH) da USP, ano III, número 5/6, janeiro/dezembro de 1995, p. 33-51.
} 
para uma exata correspondência entre o real e o pensado. Desprovido do verbo ser como verbo de ligação e com radicais sem uma determinação semântica fixa, o árabe se caracteriza justamente pela intencionalidade ao falar. Lohmann acrescenta:

O árabe, como o semítico em geral, de um lado, e o grego, de outro,
estabelecem relações com o mundo: um, principalmente pelo ouvido e o
outro, pelo olho. Tal fato levou o falante semítico a uma preponderância da
religião, enquanto o grego tornou-se o inventor da teoria. Daí decorre (ou
procede...?) uma diferença análoga das respectivas línguas, quanto a seu tipo
de expressão. Cada um desses dois tipos caracteriza-se por um procedimento
gramatical específico: flexão de raízes no semítico e flexão de temas no indo-
europeu antigo. ${ }_{536}$

Além de conhecer o sistema ma'na, talvez fosse útil ao homem ocidental contemporâneo - a fim de lidar melhor com as metáforas e utilizar-se delas como fonte de conhecimento de todas as coisas - voltar-se aos antigos, aos cristãos da primeira Idade Média, que como ninguém souberam se inspirar nas alegorias para conduzir suas existências. Embora às vezes possam ter exagerado na sua concepção simbólica da vida, eles podem servir como um importante contraponto para o homem de hoje, que tende a desenvolver uma visão extremamente racionalista do mundo. Dos sermões de Santo Agostinho ao Livro da interpretação dos nomes bíblicos, de Jerônimo, da poesia de Rusticos Helpidus às etimologias de Isidoro de Sevilha, a alegoria, a metáfora e o simbolismo sempre estarão presentes nos autores medievais, como a mostrar o caminho para o conhecimento.

O que se afirmou até aqui implica importantes consequências para a educação, para a filosofia e para a teologia. Na área da educação, as implicações são óbvias e já sabidas, embora nem sempre postas em prática: como já indicava Tomás de Aquino, é necessário que o ensino não seja fastidioso ${ }^{537}$ para o espírito dos ouvintes, mas leve, agradável e atraente. Para isso, nada melhor do que ensinar através de metáforas, histórias e analogias.

$\mathrm{Na}$ área da filosofia, deve-se reter que talvez a metáfora seja uma maneira muito mais eficaz de se aproximar da essência mais profunda das coisas do que o discurso lógico-racional. Pois a vida humana está envolvida em mistérios tão insondáveis que, diante deles, os recursos da razão e da lógica se tornam precários e insuficientes. Tomese como exemplo o amor. Como é possível ao filósofo e ao cientista descrever, definir

\footnotetext{
${ }^{536}$ Johannes Lohmann, obra citada, p. 36. Confirmando as ideias de Lohmann, Jean Lauand destaca, em "Ciência e Weltanschauung - A álgebra como ciência árabe", que, não por acaso, a álgebra surgiu na cultura árabe, enquanto a geometria é produto da racionalidade grega.

${ }^{537}$ Suma teológica, prólogo.
} 
concretamente essa realidade? Como explicar o que é esse sentimento? Ele escapa inapelavelmente ao entendimento humano. Nesse caso, o melhor a fazer é recorrer à sensibilidade dos poetas, que, não através da fria consideração racional, mas da fina intuição, através de belíssimas metáforas, nos aproximam do sentido mais profundo do amor, como faz o português Luis Vaz de Camões:

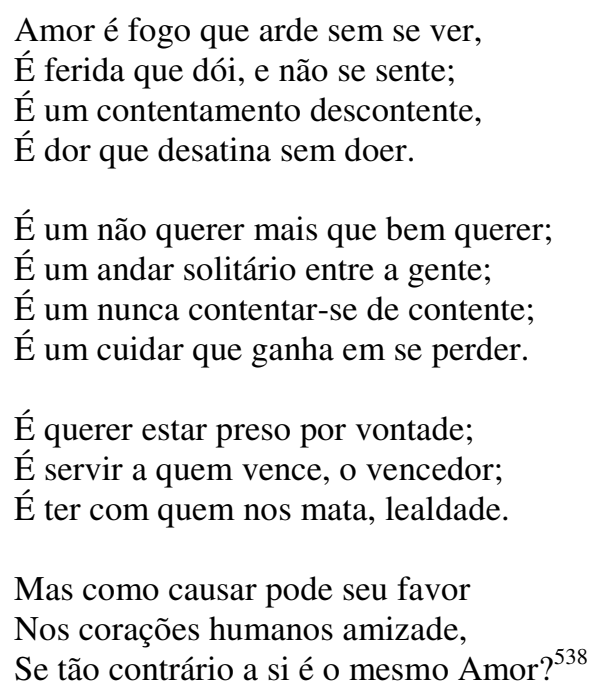

Finalmente, na área da teologia, é preciso questionar: se boa parte da Bíblia foi escrita em forma de parábolas e, nela, todas as maneiras de se referir a Deus são analogias - como foi visto neste capítulo -, por que a teologia se afastou do discurso figurado e se tornou por demais racionalista e descritivista, tentando explicar cabalmente a essência e os atributos divinos? Há que se apontar aí claramente uma influência do movimento racionalista secular, que se acentuou nos tempos modernos, com o chamado Renascimento, e se radicalizou com o Iluminismo, no século XVIII.

Talvez fosse útil para o teólogo contemporâneo aprofundar-se na metáfora e considerá-la não apenas um mero recurso didático, capaz de fazer com que as pessoas compreendam uma mensagem de conteúdo espiritual, como geralmente se imagina. Ela é muito mais do que isso. As metáforas, as analogias, as parábolas são, na realidade, o único modo de conhecer Deus, tanto quanto possível. Por isso, recorrer ao discurso metafórico é uma premente necessidade para aqueles que desejam saber um pouco mais profundamente sobre o que é insondável, inesgotável e incognoscível.

${ }^{538}$ Luis Vaz de Camões, Soneto 11. 


\section{MÍSTICA E CIÊNCIA}

O sentido original do termo "mística" diz respeito a uma forma superior de experiência, de natureza religiosa ou religioso-filosófica, que normalmente se desenrola num plano transrracional - não aquém, mas além da razão, isto é, onde cessa o discurso racional - e mobiliza as mais poderosas energias psíquicas do indivíduo, como define Henrique C. de Lima Vaz ${ }^{539}$. Segundo o autor, essas energias elevam o ser humano às mais altas formas de conhecimento e de amor, que convergem na fina ponta do espírito - o apex mentis -, numa experiência inefável do Absoluto. Ou seja, a aceitar essa definição, a experiência mística conduz a um tipo de ciência sumamente especial, acessível somente através dela - a contemplação de Deus e das coisas divinas -, daí a importância dessa forma de conhecimento tão distinta dos modos de saber tradicionais, como a lógica e a dialética.

De acordo com Lima Vaz, o Ocidente assistiu ao surgimento de três grandes formas de experiência mística, que podem ser classificadas como mística especulativa, mística mistérica e mística profética. "As duas primeiras são comuns aos misticismos grego e cristão, levando-se em conta a profunda diferença do conteúdo doutrinal das duas tradições. Já a mística profética é própria da tradição cristã, sendo essencialmente uma mística cristológica."

A mística profética se constituiu em torno da Palavra da Revelação, tal como é comunicada, recebida e vivida ao longo da tradição bíblico-cristã, afirma ainda Lima Vaz. É uma mística da audição da Palavra, isto é, que floresce no terreno da Palavra de Deus, ouvida e obedecida, que cresce até alcançar o caminho mais perfeito, o caminho do amor (agape $)^{541}$. "A mística profética pode ser assim considerada como fruto amadurecido da ação transformante da Palavra de Deus no espírito daquele que recebe essa Palavra pela Fé e que, pelo Batismo, renasce a uma vida nova." ${ }^{542}$ Ela faz o cristão participar da "sabedoria de Deus no mistério" ( $1^{a}$ Coríntios 2:7), ou seja, na revelação e conhecimento do mistério, fruto do dom do Espírito que "tudo investiga, mesmo as

\footnotetext{
${ }^{539}$ Henrique C. de Lima Vaz, Experiência mística e filosofia na tradição ocidental. São Paulo: Loyola, 2000, p. 9-10.

${ }^{540}$ Idem, obra citada, p. 30.

${ }^{541}$ Lima Vaz nota que o conceito de "mística profética", definida como "mística da Palavra", é considerado simplesmente contraditório por teólogos que vêem o cristianismo como hostil a toda espécie de mística, entre os quais se incluem K. Barth e E. Brunner.

${ }^{542}$ Idem, obra citada, p. 58.
} 
profundezas de Deus" ( $1^{a}$ Coríntios 2:10), e cuja ação se exerce na Igreja segundo a ordem dos dons e carismas ( $1^{a}$ Coríntios 12), acrescenta Lima Vaz, notando que a passagem de $1^{a}$ Coríntios 2:6-16 pode ser considerada um dos principais fundamentos neotestamentários da mística profética ${ }^{543}$.

Por sua vez, a mística mistérica se caracteriza por ser uma forma de mística em que o espaço onde se desenrola a experiência de Deus é o espaço sagrado de um rito de iniciação ou de um culto, continua Lima Vaz. A própria denominação "mistérica" é atribuída a uma forma de experiência do divino que floresceu nos antigos cultos mistéricos ou iniciáticos da tradição grega - as primeiras manifestações da mística mistérica, das quais as mais célebres são os mistérios de Elêusis e de Dionísio e o orfismo. "A experiência de Deus no mistério cristão (sacramental ou litúrgico) apresenta analogias com esses cultos, fundadas em algumas influências históricas, o que explica em parte a presença de certa forma de mística mistérica na tradição cristã." ${ }^{, 544}$ Para Lima Vaz, era inevitável que algo da linguagem e da temática do mystérion helenístico viesse a ser assimilado no anúncio do que o apóstolo Paulo chama de "o mistério de Deus revelado em Jesus Cristo", que inspirará uma mística mistérica autenticamente cristã. O autor acrescenta:

\begin{abstract}
A mística mistérica cristã organiza-se, pois, em torno das categorias de Batismo, Ressurreição e Vida nova - categorias fundamentais em Paulo e João -, em que a vida verdadeira é tanto a vida revelada e oferecida no mystérion de Cristo quanto a vida recebida e vivida pelo cristão na sua participação ou incorporação a esse mystérion. A primeira constitui a dimensão objetiva de mística mistérica cristã; a segunda, sua dimensão subjetiva. Por sua vez, a dimensão objetiva do mystérion cristão pode ser considerada sob dois aspectos que permitem, de resto, estabelecer com maior exatidão suas relações com o mystérion helenístico: o primeiro diz respeito à revelação do mystérion segundo o modelo do kérygma paulino e joanino; o segundo refere-se à dimensão cultual do mystérion, que se desenvolve e enriquece ao longo do desenvolvimento da liturgia cristã até atingir o esplendor da ação litúrgica descrita e alegorizada pelo Pseudo Dionísio em seu De ecclesiastica hierarchia. ${ }^{545}$
\end{abstract}

Apesar da importância dessas duas formas de experiência mística, queremos deixá-las de lado neste momento e nos deter na chamada mística especulativa, mais diretamente relacionada com os objetivos deste capítulo. Para Lima Vaz, a mística especulativa pode ser considerada um prolongamento da experiência metafísica em termos de intensidade experencial. Ela se apresenta, diz o autor, como a face do pensamento filosófico voltada para o mistério do Ser, tentando mergulhar seu olhar nas

\footnotetext{
${ }^{543}$ Idem, obra citada, p. 58.

${ }^{544}$ Idem, obra citada, p. 47.

${ }^{545}$ Idem, obra citada, p. 52.
} 
profundidades propriamente insondáveis e inefáveis que assinalam a fronteira última do pensamento distinto e da palavra - do logos. Ela é, assim, “o esforço mais audaz e o apelo mais radical para que o espírito humano, seguindo o roteiro do logos, penetre no domínio do translógico", afirma Lima Vaz, lembrando que o domínio da mística não é o domínio do alógico ou do irracional, mas do translógico: a realidade que se alcança com um passo além do lógico ou do pensamento conceitual ${ }^{546}$.

Ainda a respeito da mística especulativa, Lima Vaz destaca:

\begin{abstract}
Ela floresce, assim, historicamente, nas proximidades dos grandes surtos do pensamento metafísico que marcaram a história da filosofia de Parmênides a Hegel. Nesse sentido, pode-se dizer que, em sua versão ocidental, a mística especulativa é originariamente grega, não obstante o vigoroso crescimento que conheceu em terras cristãs. Situa-se na vertente noética da consciência, desabrochando como que no seu vértice. É, portanto, uma mística do conhecimento, e essa é a feição original que a distingue na história da Mística. $^{547}$
\end{abstract}

Os estudiosos reconhecem em Platão a fonte primeira da mística especulativa. Segundo Lima Vaz, os temas e conceitos platônicos irão constituir um organismo teórico que será animado por correntes sucessivas de vida mística na antiguidade grega e no cristianismo dos primeiros séculos. "A mística especulativa será, pois, fundamentalmente uma mística platônica, e será sob o patrocínio de Platão que mística e filosofia se unirão por estreitos laços na tradição do Ocidente." ${ }^{548}$

Fiel às suas origens platônicas, a mística especulativa apresenta-se dotada de uma estrutura fundamental, que permanecerá constante ao longo da história, continua Lima Vaz. Essa estrutura é sustentada por dois grandes eixos: o subjetivo e o objetivo. O eixo subjetivo se refere a uma ordenação vertical e hierárquica das atividades cognoscitivas da alma e das formas de conhecimento, culminando com a inteligência no seu ato mais elevado. Nesse caso, admite-se que o conhecimento humano pode se elevar até o cimo da mente, onde se dá a intuição do divino. Já o eixo objetivo diz respeito à pressuposição de que, à capacidade do ser humano de conhecer e amar o Absoluto, corresponde a realidade objetiva desse mesmo Absoluto.

De um lado, aí se manifesta o supremo esforço do espírito humano para alcançar, pelo conhecimento e pelo amor, o vértice da pirâmide do ser, tal como parece elevar-se aos olhos da sua inteligência. De outro, esse vértice do ser, apenas entrevisto, distancia-se ao infinito, mergulhado numa profundidade insondável, para além de toda intuição distinta."549

\footnotetext{
${ }^{546}$ Idem, obra citada, p. 30.

${ }^{547}$ Idem, obra citada, p. 30.

${ }^{548}$ Idem, obra citada, p. 31.

${ }^{549}$ Idem, obra citada, p. 32-33.
} 
A tradição da mística especulativa se desdobra em duas grandes faces: a mística neoplatônica e a mística cristã. Para Lima Vaz, o neoplatonismo é a matriz teórica e linguística da mística especulativa, tendo os textos de Plotino como que suas "escrituras canônicas".

Os traços fundamentais da mística plotiniana dizem respeito, de um lado, à estrutura da alma e da inteligência e aos degraus correspondentes para a subida contemplativa; de outro, referem-se à natureza da união final no ápice da theoria entre a inteligência e o Uno. "Nesses dois temas da mística plotiniana estão presentes aqueles que serão os tópicos clássicos da mística especulativa: estrutura do espírito, degraus de ascensão mística, contemplação terminal, natureza do Absoluto e linguagem da contemplação." ${ }^{, 50}$

Se Plotino é o grande patrono da mística neoplatônica, no que se refere à mística cristã esse papel cabe ao Pseudo Dionísio Areopagita, responsável mesmo pela introdução definitiva da expressão "teologia mística" na literatura cristã. Isso se deve basicamente ao seu curto mas tão influente livro Da teologia mística - expressão máxima da busca pelo conhecimento das coisas divinas através da experiência transrracional -, que, dada sua importância, passamos a comentar.

Da teologia mística é escrito em forma de conselhos para Timóteo, em mais uma fina ironia do Pseudo Dionísio Areopagita ${ }^{551}$. O primeiro capítulo começa com uma oração à "Trindade supraessência, supradivindade, suprabem". Nela, o autor pede que "a guardiã da sabedoria divina dos cristãos" o guie até além do não-saber e da luz, até além dos discursos místicos, onde os mistérios da Palavra de Deus são simples, absolutos e imutáveis. Ali as trevas mais que luminosas do silêncio mostram segredos que transbordam em meio às mais negras trevas. Ali as mentes são inundadas por mistérios de fulgores formosíssimos, absolutamente intangíveis e invisíveis.

Nessa oração, o Pseudo Dionísio Areopagita expõe o objetivo do livro e o seu projeto: atingir o Absoluto e conhecer mistérios inacessíveis ao ser humano, a não ser através da experiência mística.

Em seguida, ao aconselhar Timóteo a buscar esse conhecimento, o autor sugere como que um "método" para chegar à contemplação mística. Segundo ele, é preciso

\footnotetext{
${ }^{550}$ Idem, obra citada, p. 34.

551 Timóteo foi discípulo de Paulo, a quem o apóstolo escreveu duas cartas, hoje inseridas no cânon do Novo Testamento. A referência a Timóteo em Da teologia mística é mais uma tentativa do autor do Corpus dionysiacum de se fazer passar pelo membro do Areópago de Atenas convertido através do discurso de Paulo, citado em Atos dos apóstolos 17: 34.
} 
renunciar aos sentidos, às operações intelectuais, ao sensível e ao inteligível, despojar-se de tudo o que existe, deixar de lado o entendimento e distanciar-se de si mesmo e de todas as coisas. Aqui é revelado o estado místico, ou seja, o estado da alma que deseja unir-se a Deus, que está "além de todo ser e de todo saber" - algo muito bem definido, que não se confunde com uma mera meditação ou uma oração, visto que estas são sensações que também devem ser abandonadas. Trata-se, como o Pseudo Dionísio Areopagita dirá em seguida, de um absoluto silêncio.

Enfatizando o caráter de mistério iniciático da experiência mística cristã, o autor recomenda a Timóteo que mantenha esses segredos longe dos profanos, dos nãoiniciados. Entre estes estão incluídos aqueles que consideram nada existir além do mundo sensível, aqueles que supõem conhecer o divino através de sua sabedoria humana e ainda aqueles que confundem a divindade com os ídolos fabricados por eles mesmos.

É lícito atribuir à Causa de todas as coisas tudo o que se diz a respeito dos seres, pois estes são efeitos daquela. Mas, ao mesmo tempo, deve-se negar ao Absoluto os atributos vistos nos seres, pois Ele transcende supraessencialmente tudo o que existe. Afirmar e negar, porém, não estão em contradição, pois a Causa está acima de toda afirmação e negação.

Referindo-se ao apóstolo Bartolomeu ${ }^{552}$ - para quem a Palavra de Deus seria ao mesmo tempo "copiosa e mínima" e o Evangelho, "amplo, abundante", mas também "conciso" -, o Pseudo Dionísio Areopagita destaca que a Causa universal é simultaneamente eloquente e silenciosa, plena de palavras e sem palavra nenhuma. Ela transcende todas as coisas, ocultando-se no infinito, mas se revela aos iniciados. Estes são aqueles que deixam para trás as coisas puras e as coisas impuras, ultrapassam as coisas celestiais, abandonam as luzes, as vozes e as palavras divinas e penetram nas trevas onde se encontra Aquele que está acima de todo ser.

De fato, pode-se dizer que a Causa de todas as coisas é eloquente porque ela "fala" através dos seres criados, sendo o mundo mesmo uma grande metáfora de Deus. Mas isso não quer dizer que, por essa maneira tão fraca e deficiente, se possa conhecer

\footnotetext{
${ }^{552}$ Bartolomeu era um dos apóstolos de Cristo, citado no Novo Testamento (Mateus 10:3, Marcos 3:18 Lucas 6:14 e Atos dos apóstolos 1;13). A ele é atribuído um texto apócrifo intitulado Evangelho de Bartolomeu, em que não se encontram as palavras citadas pelo Pseudo Dionísio Areopagita. Certamente, a referência a Bartolomeu é mais um recurso do autor para se fazer passar por uma pessoa íntima dos apóstolos.
} 
verdadeiramente o Criador, que permanece oculto e só se revela através da experiência mística.

Experiência cujo exemplo perfeito é o episódio de Moisés no Monte Sinai, como relatado no livro do $\hat{E x o d o}{ }^{553}$, em que Deus fala ao líder do povo hebreu. Moisés recebe do Senhor a ordem de se purificar e se afastar dos não-purificados. Retirando-se do meio da multidão, do barulho das trombetas e da visão de luzes, acompanhado dos sacerdotes escolhidos, chega ao cume do monte e contempla não o Invisível - posto que ninguém jamais viu Deus -, mas o lugar onde Ele habita. Para o Pseudo Dionísio Areopagita, esse episódio significa que as coisas mais santas e sublimes percebidas pelos olhos e pela razão são apenas meios pelos quais pode-se conhecer a presença daquele que a tudo transcende. Através deles, faz-se manifesta a sua presença.

Depois dessa visão, Moisés se afasta de tudo o que é visível, para penetrar nas misteriosas trevas do não-saber ${ }^{554}$, como descreve o Pseudo Dionísio Areopagita:

\begin{abstract}
Ali, renunciando a tudo o que a mente pode conceber, entregue totalmente ao que não percebe nem compreende, deixa-se abandonar por completo naquele que está mais além de todo ser. Ali, sem pertencer a si mesmo e a nada, renunciando a todo conhecimento, fica unido pelo mais nobre do seu ser com Aquele que é totalmente incognoscível. Ao mesmo tempo em que nada conhece, entende além de toda inteligência. ${ }^{555}$
\end{abstract}

Nesse relato de Moisés no Monte Sinai encontra-se o modelo e a "regra" para todo místico, que deve abandonar qualquer tipo de sensação para se unir ao Absoluto. Mas isso exige um processo que se inicia com a purificação, passa pela ascensão e chega à contemplação de Deus - o clássico itinerário místico.

No capítulo II de Da teologia mística, o Pseudo Dionísio Areopagita afirma que ver e conhecer Deus, "a supravisão e conhecimento", significa ver e conhecer "na realidade”. Isso leva à ideia já mencionada no início deste capítulo: a experiência mística conduz a um conhecimento sumamente especial, à ciência mais alta possível, só acessível através dessa experiência, e não do discurso racional - a contemplação de Deus e das coisas divinas. Observem-se, de passagem, à luz do pensamento dionisiano, as implicações disso para o filósofo racionalista contemporâneo, que, confiado apenas

\footnotetext{
${ }^{553} \hat{E}$ xodo 19 e 20.

${ }^{554}$ Essa expressão - "trevas do não-saber" -, retirada desta passagem de Da teologia mística, terá longa e frutífera trajetória ao longo da história da mística cristã. Ela está na origem de Cloud of Unknowing, a obra máxima da mística inglesa do século XIV, na ideia de docta ignorância de Nicolau de Cusa e no termo "noite escura" de místicos alemães como Johann Tauler, depois consagrado por Juan de La Cruz, como observa T. H. Martin em Obras completas del Pseudo Dionísio Areopagita, Madrid, BAC, 1990, p. 373 , nota 6.

${ }^{555}$ Da teologia mística I,3.
} 
no que a razão pode conhecer, deixa escapar o "ver e conhecer na realidade", restringindo-se às coisas materiais e sensíveis, infinitamente inferiores ao "saber verdadeiro" oferecido pela mística.

Conhecer através da mística se assemelha ao trabalho dos escultores, compara o Pseudo Dionísio Areopagita. Esses artistas retiram da pedra tudo aquilo que impede a visão da beleza oculta. Da mesma forma, deve-se, na busca pela Supraessência divina, retirar, suprimir todos os seres, ou seja, nada afirmar, calar-se e buscar o silêncio. Como o autor afirma, é um procedimento contrário à afirmação. Ao afirmar, as teses vão se acumulando, desde as mais simples, primordiais, até as últimas, numa multiplicidade de palavras que não atingem o Ser. Ao suprimir as afirmações, faz-se o percurso contrário: a partir da multiplicidade de palavras, chega-se às primordiais, ao princípio de todas as coisas. É assim que se aproxima daquele desconhecido, "que está oculto sob todas as coisas conhecíveis em todas as coisas que existem", e se conhece "aquela treva supraessencial, que está escondida sob toda luz nos que existem"556.

O terceiro capítulo volta a tratar da afirmação e da negação a respeito de Deus. Nele, o Pseudo Dionísio Areopagita faz referência a três livros de sua autoria Representações teológicas, Teologia simbólica e Dos nomes divinos ${ }^{557}$-, que seriam expressão da teologia afirmativa. Essas obras indicariam duas formas de falar de Deus, a conceitual e a simbólica. Em Representações teológicas, discorre-se, por exemplo, sobre em que sentido se diz que Deus é Uno e Trino, como se entendem os conceitos de Paternidade e Filiação, como as luzes de bondade partem do Bem imaterial e indivisível e se difundem pelo mundo, sem que deixem seu eterno fundamento, e de que forma Jesus Cristo, sendo supraessencial, se revestiu substancialmente da verdadeira natureza humana. Em Dos nomes divinos, explica-se o significado de nomes como Bem, Ser, Vida e Sabedoria. Trata-se, enfim, da teologia conceitual. Já Teologia simbólica aborda as analogias que podem ter com Deus os seres observados na natureza e a relação simbólica das coisas sensíveis com a Causa primeira, sejam figuras, lugares sagrados, ornamentos ou quaisquer outras imagens com que se representa o divino.

Tanto uma forma de falar como outra, afirma o autor, exigem muitas palavras para se referir a Deus, razão por que os livros são extensos, enquanto Da teologia

\footnotetext{
${ }^{556}$ Da teologia mística II.

${ }^{557}$ Desses três, somente Dos nomes divinos é conhecido. Representações teológicas e Teologia simbólica certamente são títulos fictícios, numa outra simulação do autor. De qualquer modo, segundo o que ele informa no capítulo 3 de Da teologia mística, o conteúdo de Representações teológicas corresponde a conceitos expostos em Dos nomes divinos, enquanto Teologia simbólica reproduz ideias presentes em $D a$ hierarquia celeste e em Da hierarquia eclesiástica, livros - reais - que compõem o Corpus dionysiacum.
} 
mística ocupa poucas páginas. Quanto mais próximo da Causa, menos palavras são necessárias, porque o inteligível se apresenta cada vez mais simplificado. "À medida que adentramos aquela obscuridade que o entendimento não pode compreender, chegamos a ficar não só sem palavras, mas em perfeito silêncio e sem pensar em nada." 558

Com a teologia afirmativa e simbólica, as palavras se multiplicam, partindo do mais alto - o conceito de Deus - até o mais baixo, as coisas referentes aos homens. Já com a teologia mística, as coisas de baixo vão sendo pouco a pouco abandonadas, chegando-se ao cume das realidades divinas, onde a palavra cessa. "Ao chegar lá em cima reina um completo silêncio. Estamos unidos por completo ao Inefável."

Como que para reforçar o que foi exposto, os capítulos IV e V de Da teologia mística insistem em reafirmar que a Causa suprema da realidade sensível e de todos os conceitos não é nada de sensível e de conceitual. Com eles, o autor parece querer eliminar de uma vez por todas a mais remota ideia de que Deus pode ser comparado a algo pensável ou imaginável. No curtíssimo capítulo IV, ele se expressa assim:

\begin{abstract}
Dizemos, então, como a causa de todas as coisas, essência acima de todas as coisas, não é nenhuma substância, nem um vivente, nem uma razão, nem inteligência, nem corpo, nem tem maneira de ser, nem imagem, nem qualidade ou quantidade ou volume; nem está em um lugar, nem vê nem tem toque sensível; nem sente nem é sensível, nem tem desordem e perturbação, nem é molestada pelas paixões corporais; nem é sem força, nem colocada sob os sintomas sensíveis, nem na insuficiência é luz, nem mudança, ou corrupção, ou partilha, ou privação ou fluir, nem outro algo das coisas sensíveis. ${ }^{560}$
\end{abstract}

Depois de suprimir todas as coisas sensíveis, o capítulo V completa a ascensão a Deus negando tudo o que é conceitual. Ele não é nem sopro de vida nem intelecto, não tem imaginação, opinião ou razão. Não afirma nem pensa. Nem vive nem é vida. Não é ciência nem verdade nem sabedoria. Nem é algo das coisas que não são nem é algo das coisas que são. Não é erro nem verdade. Em resumo, a Causa perfeita de todas as coisas está infinitamente além de toda afirmação e negação, além de todo símbolo e de todo conceito, razão pela qual nada pode ser dito ou negado a seu respeito, sendo a mística a única via de acesso a ela.

Esse rápido percurso pela obra do Pseudo Dionísio Areopagita é suficiente para deixar claro que o termo "mística" não possui, nele, nenhuma relação com magias,

\footnotetext{
${ }^{558}$ Da teologia mística III.

${ }^{559}$ Idem.

${ }^{560}$ Da teologia mística IV.
} 
estigmas e irracionalismos, como se costuma pensar a respeito daquela expressão. Teodoro H. Martin cita com precisão uma definição dada por B. Jiménez Duque: "Mística é viver profundamente o mistério cristão"561. Para Martin, a teologia mística de Dionísio consiste em tomar consciência e adentrar vivencialmente no Mistério, em Deus. Por isso seu livro é tão breve, como quem fala para mandar calar. "O autor se comporta misticamente. Não é um estudo reflexivo sobre o Mistério. Isso seria uma teologia da mística, que poderia ser feita por qualquer teólogo sério, sem que seja necessariamente místico." ${ }^{562}$

Na teologia de Dionísio, afirma Martin, os jogos dialéticos de símbolos, ideias, semelhanças e dessemelhanças, inteligíveis ou ininteligíveis e as referências analógicas do múltiplo ao Deus invisível servem para fazer o homem chegar até os umbrais da união com o divino:

\begin{abstract}
Obter nossa divinização mediante o conhecimento de Deus é o fio de ouro que entretece as obras de Dionísio. É o horizonte das teologias simbólica e discursiva, que progridem por via de afirmação e negação, inseparáveis como método. "Mas a maneira mais digna de conhecer a Deus se alcança não sabendo, pela união que ultrapassa todo entender." Por conseguinte, Deus, enquanto está mais além de nossos saberes, é o objeto da mística, o ponto de mira com que se orienta toda teologia. Da teologia mística, portanto, não é um apêndice ornamental, e sim cabeça que move todo o organismo, como a cúpula de Santa Sofia dá sentido ao edifício. Na realidade, falar de teologia mística é, de certo modo, uma contradição, porque está mais além de tudo o que se pode dizer ou pensar. ${ }^{563}$
\end{abstract}

Se para Plotino e o neoplatonismo o círculo estrutural de saída e retorno se encerra perfeitamente no Bem, culminando o ideal filosófico uma vez alcançada a meta do retorno, para o Pseudo Dionísio Areopagita, como cristão, ele não é um mero término, mas sim plataforma de onde se avança para o Raio divino supraessencial, como afirma Martin. E, ao encontrar o Inefável, nada satisfaz mais do que o silêncio. A multiplicidade de palavras e ideias obstrui a contemplação do Uno, simples, indivisível, Declarar o estado de união com o Invisível - continua Martin - é tormento para o místico. Não há palavras ou ideias adequadas para se referir a ele. "Silêncio é a expressão da teologia mística. O invisível Raio de treva se reflete na via negativa, método indireto, pelo qual se manifesta o segredo intraduzível. É a maneira de dizer

\footnotetext{
${ }^{561}$ T. H. Martin, Obras completas del Pseudo Dionísio Areopagita, p. 84.

${ }^{562}$ Idem, idem, p. 85.

${ }^{563}$ Idem, idem, p. 85.
} 
mais e melhor falando menos e negando tudo. Assim procede Dionísio em Da teologia mística."564

Porém, o método negativo encontra-se em conflito com a teologia mística por ser discursivo - enquanto a mística está acima de todo discurso - e porque a negação supõe a afirmação, que a mística deixa para trás, concorda Martin. Segundo esse autor, quando o místico, sob impulso de Deus mesmo, sente a necessidade de falar a outros, recorrerá ao símbolo, como "divina treva" e "a nuvem de Moisés", por exemplo.

Desse modo, o místico resulta um grande poeta, mais notório se desfruta de formação literária. A mística e seu método consistem em uma experiência imaterial, supracognoscitiva, que nem os sentidos nem o entendimento percebem diretamente, com a firme e filial persuasão de que Deus é "totalmente incognoscível". 565

Martin acrescenta ainda que o "silêncio" e o "não-saber" do Pseudo Dionísio Areopagita não se confundem, de nenhuma maneira, com inércia ou uma preguiçosa passividade. A contemplação ou "mística teologia" é um dom de Deus que entra em plenitude quando o homem se purifica. Como diz Martin:

A capacidade de transcender, como diria Pascal, é a plena realização do homem, nunca mais idêntico consigo mesmo quando sai de si mesmo para descansar no Outro. É o êxtase (...), o coroamento da vida cristã pelo qual vive a alma habitualmente mais em Deus do que em si mesma, entregue por completo à contemplação mística. ${ }^{566}$

Não há dúvida de que a teologia mística do Pseudo Dionísio Areopagita influenciou o maior dos teólogos medievais, Tomás de Aquino. Como de costume, o Aquinate não assimila servilmente o pensamento dionisiano, mas reelabora ideias e conceitos de acordo com seus propósitos, a fim de expor mais claramente uma realidade. Em Tomás, a vida mística consiste na contemplação, é entendida como uma ciência secreta divina - infundida por Deus passivamente na alma através do amor - e constitui a maior plenitude possível para o homem, como afirma Martín $\mathrm{F}$. Echevarría $^{567}$.

Tomás trata da vida contemplativa especialmente em quatro questões da Suma teológica ${ }^{568}$. Ali ele afirma:

\footnotetext{
${ }^{564}$ Idem, idem, p. 88.

565 Idem, idem, p. 89.

${ }^{566}$ Idem, idem, p. 89-90.

${ }^{567}$ Martín F. Echevarría, "La vida mística, perfección del hombre según Santo Tomás”, in E-Aquinas, Revista electrónica mensual del Instituto Univesitario Virtual Santo Tomás (ano I, número 7, julho de 2003).

${ }^{568}$ Suma teológica II, II, q. 179-182.
} 


\begin{abstract}
A vida contemplativa consiste na contemplação da verdade divina; pois tal contemplação é o fim de toda a vida humana. Donde o dizer Agostinho: "Pela contemplação de Deus é-nos prometido o fim de todas as atividades de a perfeição eterna da alegria". A qual será perfeita na vida futuro, quando virmos a Deus face a face; e então ela nos tornará perfeitamente bemaventurados. Nesta vida, porém, a nossa contemplação da verdade divina é imperfeita, como por um espelho, em enigmas; o que já nos constitui um começo de bem-aventurança, iniciada nesta vida e que continuará na futura. Por isso o Filósofo põe a felicidade última do homem na contemplação do ótimo inteligível. ${ }^{569}$
\end{abstract}

A vida contemplativa consiste também na consideração de qualquer verdade - e não apenas na verdade divina -, uma vez que, pelos efeitos divinos, ou seja, pelas criaturas presentes no mundo, somos levados à contemplação de Deus, ressalta Tomás, citando a Carta aos Romanos (1:20), onde se lê que os atributos invisíveis de Deus se vêem na natureza. "Por isso, diz Agostinho que a consideração das criaturas não deve ser para nós o exercício de uma curiosidade vã e estéril, mas um grau para nos elevar ao imortal e permanente." 570

E, comentando o prazer produzido pela contemplação, Tomás afirma que contemplar a verdade convém ao homem por sua própria natureza, como animal racional - o que se refere ao ensino de Aristóteles na Metafísica: "Todos os homens têm por natureza o desejo de saber" e, portanto, se comprazem no conhecimento da verdade. Como a vida contemplativa consiste na contemplação de Deus, a que a caridade nos move, resulta que na vida contemplativa o prazer promana não só da contemplação mesma, mas também do amor divino. Sob esse duplo aspecto, acrescenta Tomás, o prazer inerente à contemplação excede todos os prazeres humanos. ${ }^{571}$

Ainda sobre o prazer que a contemplação - ou seja, a experiência mística oferece ao homem, o Aquinate afirma:

\footnotetext{
Mas a contemplação das coisas divinas, nesta vida, embora imperfeita, é contudo mais agradável que qualquer outra contemplação, por mais perfeita que seja, por causa da excelência do objeto contemplado. Por isso diz o Filósofo: "As nossas teorias são fracas relativamente a essas nobres e divinas substâncias; mas, embora o que delas conhecemos seja pouco, contudo, a elevação mesma desse conhecimento nos causa um prazer maior que tudo o mais que ele possa abranger. E o mesmo ensina Gregório: "A vida contemplativa é muito amável e cheia de doçura, exalta a alma acima de si mesma, abre-nos os tesouros celestes e torna patente o mundo espiritual aos olhos da alma". 572
}

\footnotetext{
${ }^{569}$ Suma teológica II, II, q. 180, a. 4. Tradução de Alexandre Corrêa.

${ }^{570}$ Suma teológica II, II, q. 180, a. 4. Tradução de Alexandre Corrêa.

${ }^{571}$ Idem, II, II, q. 180, a. 7.

${ }^{572}$ Suma teológica II, II, q. 180, a. 7, ad 3.
} 
Percebe-se, em Tomás, o uso de termos emprestados de Dionísio e do neoplatonismo. Os mais notórios deles são "divinização" e "deificação", palavras com que o Aquinate se refere à graça, ou seja, à participação do cristão na natureza divina, transformando-o e fazendo-o assumir a "forma" de Deus. Diferentemente do que ocorre em Da teologia mística do Pseudo Dionísio Areopagita, em que a iniciativa de "abandonar as sensações e as energias intelectuais" parece partir do sujeito, em Tomás a união com o divino é um dom exclusivo do Espírito Santo. Como ele afirma:

O dom da graça está acima das forças de toda natureza criada, pois ele nada mais é do que uma certa participação na natureza divina, que transcende toda criatura. É, portanto, impossível que qualquer criatura possa causar a graça. É, assim, necessário que somente Deus deifique, comunicando a natureza divina sob a forma de uma certa participação por modo de assimilação. ${ }^{573}$

Em outro trecho da Suma teológica, Tomás escreve:

Assim, pois, a não ser a graça santificante, nenhum outro efeito pode ser a razão de um novo modo de presença da Pessoa divina na criatura racional. Portanto, é somente pela graça santificante que há missão e processão temporal da Pessoa divina. Assim também se diz que possuímos somente aquilo de que podemos livremente usar e fruir. Ora, só se pode fruir de uma Pessoa divina pela graça santificante. Entretanto, no próprio dom da graça santificante tem-se o Espírito Santo que habita no homem. Assim, o próprio Espírito é dado e enviado. ${ }^{574}$

Essa "graça santificante" concede dons aos homens através do Espírito Santo, como explica Tomás de Aquino, referindo-se à beatitude da fruição divina:

Para que o homem chegue a ela, é preciso primeiro se tornar conforme a Deus, graças a certas qualidades espirituais, que ele aja de acordo com ela, e assim chegue à beatitude. Ora, os dons espirituais nos vêm pelo Espírito Santo; é, portanto, por ele que nós somos primeiro configurados a Deus, por ele ainda somos feitos aptos a agir, por ele a estrada da beatitude nos está sempre aberta. Tripla etapa evocada pelo apóstolo ( $2^{a}$ Coríntios 1:21-22): "É Deus quem nos deu a unção, que nos marcou com seu selo e colocou nos nossos corações o penhor do Espírito". E ainda (Efésios 1:13): "Vós fostes marcados com o selo do Espírito Santo, penhor da nossa herança". O selo se relaciona à semelhança de configuração; a unção, à atitude do homem a respeito das obras de perfeição; o penhor, à esperança que nos orienta em direção à herança celeste, a beatitude perfeita. ${ }^{575}$

Comentando essa passagem da Suma contra os gentios, Jean-Pierre Torrell ${ }^{576}$ afirma que todos os dons nos vêm pelo Espírito. Segundo o autor, pode-se fazer essa generalização porque nada está fora da influência da terceira Pessoa da Trindade. "Se

\footnotetext{
${ }^{573}$ Suma teológica I, II, q. 112, a. 1.

${ }^{574}$ Suma teológica I, q. 43, a. 3.

${ }_{575}^{5}$ Suma contra os gentios IV, 21, 6.

576 Jean-Pierre Torrell, Saint Thomas d'Aquin, maître spirituel. Fribourg: Éditions Universitaires
} Fribourg, 2002, deuxième edition. 
lembrarmos a maneira como o Mestre de Aquino fala da beatitude como lugar espiritual em que o homem-imagem se torna à semelhança perfeita do Exemplar divino; se recordarmos ainda o papel que exerce no fim último da vida humana e na organização de toda sua teologia, percebe-se imediatamente que ele não pode dizer nada de mais forte sobre a presença do Espírito Santo na vida cristã." ${ }^{577}$

Além do bem definitivo e perfeito da beatitude que nos será concedido ao fim do nosso percurso terrestre, continua Torrell, a benevolência de Deus o levou a nos adotar como filhos, de modo a garantir a certeza da sua herança. "Isso também é atribuído ao Espírito Santo, porque, segundo Romanos 8:15, nós temos recebido o Espírito de adoção, que clama em nós: Abba."578

Em outra passagem, Tomás confirma a função do Espírito Santo na obra beatificadora:

\footnotetext{
Embora a adoção seja comum a toda a Trindade, ela é, porém, apropriada ao Pai como seu autor, ao Filho como seu exemplar, ao Espírito Santo como aquele que imprime em nós a semelhança desse exemplar. ${ }^{579}$
}

Outro dos dons concedidos pelo Espírito Santo é o dom da sabedoria. Segundo Tomás, o dom da sabedoria tem como função considerar a "causa altíssima", por meio da qual todas as coisas são julgadas e ordenadas. Quem conhece a causa altíssima de um gênero - a medicina ou a arquitetura, por exemplo - é considerado sapiente, diz o Aquinate. Já o que conhece a causa absolutamente altíssima, que é Deus, pode ser chamado sábio absolutamente, pois pelas leis divinas pode julgar e ordenar todas as coisas. "O mesmo juízo o homem obtém pelo Espírito Santo, conforme aquilo da Escritura ( $1^{a}$ Cortíntios 2:15): 'O espiritual julga de todas as coisas', porque, como no mesmo lugar ( $1^{a}$ Coríntios 2:10) se diz: 'O Espírito tudo penetra, ainda o que há de mais oculto na profundidade de Deus'. Por onde é manifesto que a sabedoria é um dom do Espírito Santo." ${ }^{580}$ Considerada um dom do Espírito, a sabedoria difere da virtude intelectual adquirida, pois esta é obtida pelo esforço humano, enquanto aquela desce do alto, acrescenta Tomás. Também é distinta da fé, pois a fé está fundada na verdade divina em si mesma, ao passo que o juízo conforme a verdade divina pertence ao dom

\footnotetext{
${ }^{577}$ J.-P. Torrell, obra citada, p. 222.

${ }^{578}$ Idem, obra citada, p. 222.

${ }^{579}$ Suma teológica III, q. 23, a. 2, ad 3.

${ }^{580}$ Suma teológica II, II, q. 45, a. 1. Tradução de Alexandre Corrêa.
} 
da sabedoria. "Por onde, o dom da sabedoria pressupõe a fé, porque cada qual julga bem aquilo que conhece." $" 581$

O artigo 2 da questão 45 da Segunda Parte da Segunda Parte da Suma teológica é o lugar em que Tomás de Aquino fala da retidão do juízo por conaturalidade, próprio da sabedoria enquanto dom do Espírito Santo. Segundo ele, há dois modos de o juízo ter retidão: por causa do uso perfeito da razão ou por uma certa conaturalidade com aquilo que deve julgar. O Aquinate exemplifica esse conceito com a castidade: quem aprende a ciência moral julga retamente pela indagação racional, mas quem tem o hábito da castidade julga retamente tal objeto por uma certa conaturalidade com ele. "Por onde, julgar retamente das coisas divinas pela indagação racional é próprio da sabedoria, que é uma virtude intelectual, mas julgá-las retamente por uma certa conaturalidade com elas é próprio da sabedoria enquanto dom do Espírito Santo." ${ }^{, 52}$ A esse respeito, Tomás cita ainda o capítulo II de Dos nomes divinos, em que o Pseudo Dionísio Areopagita se refere a seu suposto mestre Hieroteo, que era "perfeito nas coisas divinas" não só porque as aprendeu intelectualmente, mas porque as conhecia por conaturalidade.

Acrescente-se que Tomás de Aquino associa o dom da sabedoria à sétima bemaventurança, justificando-o de uma maneira que realça a mística da filiação divina:

\begin{abstract}
A sétima bem-aventurança corresponde perfeitamente ao dom da sabedoria, tanto quanto ao mérito como quanto ao prêmio. Pois ao mérito é relativo o dito "Bem-aventurados os pacíficos". E pacíficos se chamam, por assim dizer, os que estabelecem a paz, tanto em si mesmos como nos outros. O que num e noutro caso se dá reduzindo-se à ordem devida as coisas que constituem a paz. Pois a paz é a tranquilidade da ordem, como diz Agostinho. Ora, ordenar é próprio do sábio, como está claro no Filósofo. Por onde, o atributo de ser pacífica é convenientemente predicado da sabedoria. Por outro lado, ao prêmio se refere o dito: "Serão chamados filhos de Deus". Ora, filhos de Deus se chamam os que participam da semelhança do Filho unigênito e natural, conforme aquilo do Apóstolo - "Os que conheceu na sua presciência para serem conformes a imagem de seu Filho", o qual é a Sabedoria gerada. Portanto, participando do dom da sabedoria o homem alcança a filiação divina. ${ }^{583}$
\end{abstract}

O dom do intelecto ou da inteligência - outra dádiva do Espírito Santo - também está diretamente relacionado com a contemplação. Segundo Tomás, o nome intelecto implica um conhecimento íntimo, como a palavra dá a entender: inteligir é como ler interiormente. Isso fica claro, diz o Aquinate, ao se considerar a diferença entre intelecto e sentido. O conhecimento sensível tem por objeto as qualidades exteriores sensíveis, enquanto o conhecimento intelectual penetra até a essência das coisas, pois o seu objeto

\footnotetext{
${ }^{581}$ Idem. Tradução de Alexandre Corrêa.

${ }^{582}$ Idem, II, II, q. 45, a. 2. Tradução de Alexandre Corrêa.

${ }^{583}$ Suma teológica II, II, q. 45, a. 6. Tradução de Alexandre Corrêa.
} 
é a quididade das coisas, como diz Aristóteles em De anima. Também o inteligível é, de certo modo, interno em relação a sensível, apreendido externamente. Assim, tendo em vista que o conhecimento do homem começa pelos sentidos, pelo que é exterior, quanto mais forte for a luz do intelecto, mais profunda será sua penetração. "Ora, o lume do nosso intelecto, sendo de virtude finita, tem um grau limitado de penetração. Por isso o homem necessita de um lume sobrenatural, para chegar a certos conhecimentos que não pode alcançar só pelo lume natural." ${ }^{584}$ Esse lume sobrenatural dado ao homem chamase dom do intelecto.

E Tomás completa:

Pelo lume natural infuso em nós conhecemos somente certos princípios gerais, naturalmente conhecidos. Mas, como o homem se ordena a uma felicidade sobrenatural, segundo já se disse, é forçoso alcance certas noções mais elevadas. E para isso é necessário o dom do intelecto. ${ }^{585}$

O dom do intelecto, sustenta Tomás, corresponde à sexta bem-aventurança "Bem-aventurados os limpos de coração, porque eles verão Deus" (Mateus 5:8). Segundo o Aquinate, há duas espécies de pureza: uma relativa à depuração das afeições desordenadas, que opera pelas virtudes, e outra referente à visão divina, que é a pureza da mente, depurada dos erros, de modo que as verdades propostas por Deus não sejam deterpadas. Esse segundo tipo de pureza provém do dom do intelecto.

Semelhantemente, continua Tomás, há duas espécies de visões de Deus, ambas ligadas ao dom do intelecto: uma perfeita, pela qual vemos a essência divina - trata-se do dom consumado do intelecto, como existirá na eternidade -, e outra imperfeita, pela qual, embora não vejamos quem é Deus, vemos, contudo, o que não é. "E, nesta vida, tanto mais perfeitamente o conheceremos quanto mais compreendermos que excede a tudo quanto podemos apreender pelo intelecto."

Finalmente, queremos fazer referência ainda a mais um dom do Espírito Santo o dom da ciência. Tomás afirma que, quando homem se vê diante de uma verdade, pela razão natural e segundo o intelecto, ele se aperfeiçoa através dessa verdade de duas formas: pelo aprender e pelo juízo certo que dela faz. Por isso, duas condições são exigidas para o intelecto humano assentir perfeitamente à verdade da fé: uma é compreender bem o objeto proposto - o que pertence ao dom do intelecto - e outra é

\footnotetext{
${ }^{584}$ Suma teológica II, II, q. 8, a. 1. Tradução de Alexandre Corrêa.

${ }^{585}$ Suma teológica II, II, q. 8, a. 1, ad 1. Tradução de Alexandre Corrêa.

${ }^{586}$ Suma teológica II, II, q. 8, a. 7. Tradução de Alexandre Corrêa.
} 
fazer um juízo certo e reto do objeto proposto, discernindo o que deve crer do que não deve. Para esta última é necessário o dom da ciência. ${ }^{587}$

Ao dom da ciência corresponde a terceira bem-aventurança - "Bem-aventurados os que choram, porque serão consolados". Segundo Tomás, à ciência pertence o reto juízo sobre as criaturas. E há criaturas pelas quais os homens ocasionalmente se desviam de Deus. Pensando existir nas coisas criadas o bem perfeito, constituem nelas o seu fim e perdem o verdadeiro bem. "Ora, esse dano, o homem conhece julgando retamente das criaturas, o que faz pelo dom da ciência." ${ }^{588}$ O choro que acompanha a triste descoberta do erro justifica a correspondência entre esse dom e a terceira bemaventurança.

Diante dessas ideias de Tomás de Aquino, não é de estranhar que Torrell dê o nome de "espiritualidade da deificação" à mística tomasiana. Segundo o autor, o Aquinate conhece o vocabulário da deificatio e da deiformitas, que utiliza em seus comentários sobre o Pseudo Dionísio Areopagita e em outras obras. "Mais importante do que as palavras, a realidade da divinização é a da graça, uma estrutura deiforme que assimila e torna conforme a Deus", escreve Torrell. "Disso resulta que - contrariamente à impressão que podem deixar tantos manuais de espiritualidade - ele não acentua o esforço moral do homem - como se a santidade fosse uma conquista forçada -, mas sobre a obra da graça em nós, pela qual o Pai nos configura à imagem do Filho primogênito." 589

Já Lima Vaz comenta que Tomás de Aquino é o artífice de uma "teologia da mística" - distinta da "teologia mística" -, na qual a vida contemplativa e o ato da contemplação recebem seu estatuto teológico e adquirem o perfil conceitual que serão reconhecidos como definitivos na teologia católica. Por outro lado, continua o autor, ao introduzir na análise da contemplação mística, como fruto da sabedoria que acompanha a virtude teologal da caridade, a categoria de origem aristotélica do "conhecimento por conaturalidade", Tomás delineia uma "solução genial" para o problema da mística especulativa cristã, qual seja, o problema do amor que conhece, do conhecimento (ou ciência) que procede do amor ou que conhece amando. "Tomás de Aquino se nos apresenta, assim, como o grande mestre da inteligência espiritual coroada pela

\footnotetext{
${ }^{587}$ Suma teológica II, II, q. 9, a. 1.

${ }^{588}$ Suma teológica II, II, q. 9, a. 4. Tradução de Alexandre Corrêa.

589 J.-P. Torrell, obra citada, p. 498-499.
} 
contemplação mística - sendo ele mesmo um grande místico - ou ainda como o grande doutor do 'saber comunicável' sobre a contemplação.",590

Para ilustrar a mística tomasiana, que enfatiza a contemplação e constitui a única via para o conhecimento das coisas mais profundas sobre Deus, por meio do dom da sabedoria, busquemos na Bíblia exemplos de pessoas que passaram por tal experiência e ascenderam a uma ciência inefável. Isso será suficiente para mostrar que, para a tradição cristã, a experiência mística de que fala o Aquinate não é mera abstração, mas sim uma realidade para aqueles escritores sagrados que, pela contemplação, conheceram verdades transcendentes e as transmitiram ao mundo através dos seus escritos.

Além do já citado episódio de Moisés, que o Pseudo Dionísio Areopagita comenta em sua Da teologia mística, há que se lembrar, por exemplo, no apóstolo João, em seu exílio na ilha de Patmos. "Achei-me em espírito, no dia do Senhor, e ouvi, por detrás de mim, grande voz, como de trombeta" ${ }^{, 51}$, relata João. Em outro momento, ele diz: "Depois dessas coisas, olhei e eis não somente uma porta aberta no céu, como também a primeira voz que ouvi, como de trombeta ao falar coimgo"592. E ainda: "Vi novo céu e nova terra, pois primeiro céu e a primeira terra passaram, e o mar já não existe. Vi também a cidade santa, nova Jerusalém, que descia do céu, da parte de Deus, ataviada como noiva adornada para o seu esposo" ${ }^{\text {.593. }}$.

O profeta Ezequiel teve uma experiência parecida. "Aconteceu no trigésimo ano, no quinto dia do quarto mês, que, estando eu no meio dos exilados, junto ao rio Quebar, se abriram os céus, e eu tive visões de Deus" 594 , ele conta no início de seu livro. "Então entrou em mim o Espírito, quando falava comigo, e me pôs em pé, e ouvi o que me falava." 595

A experiência mística parece ser, assim, a via pela qual podem-se obter os mais sublimes conhecimentos, ao permitir a contemplação das realidades divinas. Realidades que, como foi visto ao longo deste trabalho, escapam completamente ao entendimento e à imaginação humana. Ainda que as coisas criadas tenham participação no ser divino e, graças a isso, mostrem algo dele, essa revelação se dá de modo imperfeito, remoto e deficiente. Estamos separados do Criador. A contemplação pode ser o modo mais eficiente de se aproximar, de se unir e de se conformar ao Absoluto.

\footnotetext{
${ }^{590}$ Henrique C. de Lima Vaz, Experiência mística e filosofia na tradição ocidental, p. 39.

${ }^{591}$ Apocalipse 1:10.

${ }_{592}^{592}$ Apocalipse 4:1.

${ }_{593}^{593}$ Apocalipse 21:1-2.

${ }_{594}^{594}$ Ezequiel 1:1.

${ }^{595}$ Ezequiel 2:2
} 


\section{CONCLUSÃO}

Os estudos realizados ao longo deste trabalho permitem fazer algumas considerações-síntese a respeito de temas ligados à teologia, à filosofia e à educação, relacionadas a seguir.

1) É inegável a influência do Pseudo Dionísio Areopagita sobre Tomás de Aquino. Embora muito clara - como foi mostrada ao longo deste trabalho -, essa influência nem sempre foi percebida pelos estudiosos do Aquinate ao longo dos séculos. É comum apontar a importância do aristotelismo e do agostinianismo para o pensamento de Tomás, enquanto Dionísio, muitas vezes, passa despercebido. Deve-se, contudo, considerar que a teologia e a filosofia de Tomás de Aquino são marcadas principalmente por estes três pensadores: Aristóteles, Santo Agostinho e o Pseudo Dionísio Areopagita.

2) A influência do Pseudo Dionísio Areopagita é fundamental para o pensamento de Tomás de Aquino. Graças a Dionísio, Tomás é marcado pela negatividade - o conceito segundo o qual o entendimento humano não é capaz de alcançar a essência mais profunda de Deus e dos seres criados. Isso afasta Tomás de um possível racionalismo teológico e livra-o da imagem que lhe foi imposta ao longo dos séculos - de pensador convicto do poder ilimitado da razão para compreender todas as coisas.

3) $\mathrm{O}$ discurso racional sobre Deus (enfatizado por setores da teologia contemporânea ocidental) é insuficiente para atingir o conhecimento mais profundo sobre o divino. Na medida em que utiliza conceitos que se encontram sob o domínio do que é conhecido pela razão, a linguagem humana fala mais do homem do que de Deus, pois este está além de todas as coisas conhecidas e imaginadas.

4) Dado que o discurso racional é insuficiente, deve-se recorrer às metáforas ao falar de Deus, que de algum modo podem revelar mais claramente as coisas divinas. Não à toa, a Bíblia e o Alcorão são livros repletos de metáforas, parábolas e símbolos. O falar em metáforas não é um mero recurso pedagógico para atrair a atenção dos ouvintes. Trata-se, antes, da única maneira possível de lidar com as realidades espirituais mais profundas. 
5) Mesmo assim, as metáforas ainda são insuficientes e precárias. O mais profundo conhecimento de Deus se dá através da união mística com o divino - entendida como uma experiência com o Absoluto que se dá num plano além da razão, e não aquém.

6) O mundo visível, a matéria - que em certos discursos teológicos e doutrinários (e, por vezes, mais ou menos conscientemente, em tantas pregações e práticas pastorais) são vistos como intrinsecamente "maus", em contraposição às coisas espirituais, que são "boas" - detêm a mais elevada dignidade, uma vez que são criações de Deus e, como tal, revelam de alguma forma algo do Criador. O homem, a planta, os animais, a pedra, o Universo tudo tem participação no ser divino e traz "vestígios" dele, ainda que de modo remoto e deficiente. A participação não se confunde com o panteísmo, pois há um abismo que separa os seres criados ex nihilo, a partir do nada, do princípio causal de todas as coisas.

7) Os setores do pensamento contemporâneo limitados pelo racionalismo não podem - justamente por causa dessa limitação - atingir o seu objetivo mais alentado: chegar ao conhecimento pleno das coisas. Deve-se, antes, reconhecer que o saber mais profundo se encontra no âmbito suprarracional, como foi percebido já nas primeiras manifestações do pensamento racional, na Grécia antiga. Restringir-se ao que a razão é capaz de compreender cabalmente significa reduzir lamentavelmente o conhecimento humano e renunciar à mais fascinante aventura possível: a contemplação de todas as coisas divinas e humanas, que caracteriza o legítimo filosofar. Deve-se lembrar, porém, que essa aventura, essa viagem do conhecimento é inesgotável, e o homem jamais alcançará seu término nesta vida.

8) Dada a ausência de clareza absoluta no que se refere às coisas divinas e humanas - como se depreende do conceito de negatividade -, é de fundamental importância o conhecimento da doutrina cristã da prudência, a virtude do agir corretamente, com base no conhecimento da realidade concreta, afinal procedente da experiência do homem bom, e sem a certeza de teoremas geométricos.

9) Assim como a filosofia, a educação contemporânea também está sujeita às tentações do racionalismo, com todas as limitações e insuficiências deste. $\mathrm{O}$ pensamento negativo do Pseudo Dionísio Areopagita e de Tomás de Aquino 
pode colaborar para a formulação de uma pedagogia mais acertada, lúdica e sensível e menos apegada à rigidez da certeza lógica.

10) $O$ cristianismo do século $X X I$, se resgatar o pensamento negativo de Dionísio e de Tomás, recuperará o espírito de simplicidade e humildade do Evangelho, e deixará espaço para a "criatividade" do fiel e para uma ampla espiritualidade, em detrimento de igrejas rigorosamente organizadas, com detalhados códigos morais. 


\section{BIBLIOGRAFIA CITADA}

Livros do Pseudo-Dionísio Areopagita

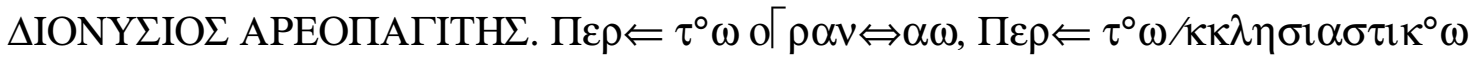

$\Downarrow_{\varepsilon \rho} \alpha \rho \xi \Leftrightarrow \alpha \omega, \Pi \varepsilon \rho \Leftarrow \Psi \varepsilon \Leftrightarrow \varpi \nu \mid v o \mu \quad \tau \varpi \nu, \Pi \varepsilon \rho \Leftarrow \mu v \sigma \tau \iota \kappa^{\circ} \omega \psi \varepsilon \sigma \lambda \circ \gamma \Leftrightarrow \alpha \omega, \mathrm{Pa}$ trologiae

Graecae, tomus 3, Accurante J. P. Migne, Paris, Brepols, 1857 (édition originale), 2002 (réimpression). . Obra completa, tradução de Roque Aparecido Frangiotti. São Paulo:

Paulus, 2004. Oeuvres completes. Paris: Aubier, 1943.

. Obras completas. Madrid: Biblioteca de Autores Cristianos (BAC), 1990. . Teologia mística, tradução de Marco Lucchesi. Rio de Janeiro: Fissus, 2005.

Livros sobre o Pseudo-Dionísio Areopagita

ANDIA, YSABEL DE (ed.). Denys l'Aréopagite et as postérité en Orient et en Occident - Actes du Colloque International, 21-24 septembre 1994. Paris: Institut d'Études Augustiniennes, 1997.

O'ROURKE, FRAN. Pseudo-Dionysius and the metaphysics of Aquinas. Notre Dame: University of Notre Dame Press, 2005.

THÉRY, G. Études dionysiennes I. Paris: Vrin, 1932. . Études dionysiennes II. Paris: Vrin, 1937.

Artigos sobre o Pseudo Dionísio Areopagita

BUCUR, BOGDAN G. "The theological reception of Dionysian apophatism in the Christian East and West: Thomas Aquinas and Gregory Palamas", in www.bgbucur.com/PDFuri/DionysiusApophatismDownsideReview.pdf).

CABALlERO. A. "Las ideas-clave de Los Nombres Divinos de Pseudo Dionísio según el uso léxico", in Temas Medievales, v. 12, n I, 2004).

DEVRESSE, ROBERT. "Denys l'Areopagite et Sévère d'Antioche”, in Archives d'Histoire Doctrinale et Littéraire du Moyen Age. Paris: 1929, p. 159-167. 
Livros de Tomás de Aquino

TOMÁS DE AQUINO. Corpus thomisticum (www.corpusthomisticum.org).

. Sobre a diferença entre a palavra divina e a humana, tradução de Jean

Lauand. São Paulo: GRD, 1993.

. Verdade e conhecimento, tradução de Jean Lauand e Mario Bruno

Sproviero. São Paulo: Martins Fontes, 1999.

. Suma teológica, volume I, vários tradutores. São Paulo: Loyola, 2001.

. Commento ai Nomi Divini di Dionigi, volume 1-2, traduzione a cura di

Battista Mondin. Bologna: Edizioni Studio Domenicano (ESD), 2004.

. A prudência - A virtude da decisão certa, tradução de Jean Lauand. São

Paulo: Martins Fontes, 2005.

. Sobre os anjos (De substantiis separatis), tradução de Luiz Astorga. Rio

de Janeiro: Sétimo Selo, 2006.

. Cuestiones disputadas sobre el mal, traducción de Ezequiel Téllez

Maqueo, Pamplona: Universidad de Navarra, 1997.

Livros sobre Tomás de Aquino

CAMPOS, FERNANDO ARRUDA. Tomismo hoje. São Paulo: Loyola, 1989.

GONZÁLEZ, ÁNGEL LUIS. Ser y participación - Estudio sobre La cuarta via de

Tomás de Aquino. Navarra: Ediciones Universidad de Navarra, 2001.

LAUAND, JEAN. Tomás de Aquino, hoje. São Paulo/Curitiba: GRD/Champagnat, 1993.

. Provérbios e educação moral - A filosofia de Tomás de Aquino e a pedagogia árabe do mathal. São Paulo: Hottopos, 1997.

. Em diálogo com Tomás de Aquino - Conferências e ensaios. São Paulo:

Mandruvá, 2002.

. Razão, natureza e graça - Tomás de Aquino em sentenças. São Paulo:

Centro de Estudos Árabes da Faculdade de Filosofia, Letras e Ciências Humanas (FFLCH) da Universidade de São Paulo (USP), sem data.

TORREL, JEAN-PIERRE. Saint Thomas d'Aquin, maître spiritual. Fribourg: Éditions Universitaires Fribourg, 2002, deuxième edition.

VELDE, RUDI A. TE. Participation and substantiality in Thomas Aquinas. Leiden: E. J. Brill, 1995. 
Artigos sobre Tomás de Aquino

ECHEVARRÍA, MARTÍN F. "La vida mística, perfección del hombre según Santo Tomás”, in E-Aquinas (ano I, número 7, julho de 2003).

LAUAND, JEAN. "S. Tomás de Aquino e o Logos Criador" (www.jeanlauand.com/dominicanos.doc).

. "Tomás de Aquino e os fundamentos do Belo (a mística poética de Adélia Prado)", in Revista Dominicana de Teologia, nº 8, jan-jun 2009, p. 7-30.

LOHMANN, JOHANNES. "Santo Tomás e os árabes - Estruturas lingüísticas e formas de pensamento", in Revista de Estudos Árabes. São Paulo: Centro de Estudos Árabes da Universidade de São Paulo (USP), número 5/6, janeiro/dezembro de 1995, p. 33-51.

PIEPER, JOSEF. "O elemento negativo na filosofia de Tomás de Aquino”, tradução de Gabriele Greggersen Bretzke, Revista de Estudos Árabes, Centro de Estudos Árabes da Faculdade de Filosofia, Letras e Ciências Humanas (FFLCH) da Universidade de São Paulo (USP), número 5/6, jan/dez de 1995, p. 53-75.

Outras obras

ADÉLIA PRADO, Poesia reunida. São Paulo: Siciliano, 1991.

ARISTÓTELES. Metafísica, tradução de Vincenzo Cocco. São Paulo: Abril, 1973. ANÔNIMO. A nuvem do não saber, tradução de Lino Correia Marques de Miranda Moreira. Petróplis: Vozes, 2007.

BERKHOF, LOUIS. A história das doutrinas cristãs, tradução de João Marques Bentes e Gordon Chown. São Paulo: PES, 1992.

BUBER, MARTIN. Eclipse de Deus - Considerações sobre a relação entre religião e filosofia, tradução de Carlos Almeida Pereira. Campinas: Verus, 2007.

CALVINO, JOÃO. As institutas, volume I, tradução de Waldyr Carvalho Luz. São Paulo: Casa Editora Presbiteriana, 1985.

CASTRO, ROBERTO C. G. (org.). O intérprete do Logos - Textos em homenagem a Jean Lauand. São Paulo: ESDC/Factash, 2009.

HALL, STUART. A identidade cultural na pós-modernidade, tradução de Tomaz Tadeu da Silva e Guacira Lopes Louro. Rio de Janeiro: DP\&A, 2005, 10 a edição. JARDÉ. A. A Grécia antiga e a vida grega, tradução de Gilda Maria Reale Starzynski. São Paulo: EPU/Edusp, 1977. 
JONES, PETER V. (org.). O mundo de Atenas, tradução de Ana Lia de Almeida Prado. São Paulo: Martins Fontes, 1997.

LAMARTINE. Méditations poétiques. Paris: Garnier, 1950.

LAO-TSE. Tao te ching, tradução de Mário Bruno Sproviero. São Paulo: Mandruvá, 1997.

LAUAND, JEAN. O que é uma universidade? - Introdução à filosofia da educação de Josef Pieper. São Paulo: Perspectiva, 1987. . Filosofia, linguagem, arte e educação. São Paulo: ESDC/Factasch, 2007. . "Boécio e o De Trinitate" (www.hottopos.com/convenit5). . Cultura e educação na Idade Média. São Paulo: Martins Fontes, 1998. . "A pedagogia de Deus: mathal no Alcorão e na Bíblia”, in Notandum 19 (janeiro-abril de 2009). São Paulo/Porto: Cemoroc/IJI. . Filosofia e linguagem comum. Curitiba: Champagnat, 1990.

LOCKYER, HERBERT. Todas as parábolas da Bíblia. São Paulo: Vida, 2006.

MANON. SIMONE. Platão, tradução de Marina Appenzeller. São Paulo: Martins Fontes, 1992.

NISSA, GREGÓRIO DE. The life of Moses, translation by Abraham J. Malherbe and Everett Ferguson. New York: Paulist Press, 1978.

PIEPER, JOSEF. Scholastik. München: DTV, 1978. . Filosofia medieval y mundo moderno. Madrid: Rialp, 1973. . Abertura para o todo - A chance da universidade, tradução de Gilda Naécia Maciel de Barros e Jean Lauand. São Paulo: Apel, 1989. "O caráter problemático de uma filosofia 'não-cristã'”, tradução de

Gabrielle Greggersen e Jean Lauand

(www.hottopos.com/mirand12/pieper.htm\#2).

PESSOA, FERNANDO. Poesias. Porto Alegre: L\&PM, 2008.

PLATÃO, Fédon, tradução de Jorge Paleikat e João Cruz Costa. São Paulo: Abril, 1972. PROCLUS. Proclus' hymns, translation by R. M. van den Berg. Leiden: Brill, 2001. RUGGIERO, GUIDO DE. La filosofia del cristianesimo. Roma: Laterza, 1967, vol. 1. VAZ, HENRIQUE C. DE LIMA. Experiência mística e filosofia na tradição ocidental. São Paulo: Loyola, 2000.

Obras de referência

The Greek New Testament, edited by Kurt Aland. Münster: 1975 (third edition). 
Nobre Alcorão, tradução de Helmi Nasr. Al-Madinah: Complexo do Rei Fahd.

\section{ANEXO: "DA TEOLOGIA MÍSTICA" (TRADUÇÃO)}

Apresentamos a seguir uma tradução inédita, direta do original grego, de Da teologia mística, do Pseudo Dionísio Areopagita, um dos livros que mais exerceram influência na teologia e na filosofia medieval. Em cinco curtíssimos capítulos, o autor expõe o ideal da teologia mística: a união com Absoluto, além de toda reflexão racional.

O texto grego utilizado foi o publicado no volume 3 de Patrologiae Graecae (Brepols, 2002). 


\section{$\triangle I O N Y \Sigma I O Y$ АРЕОПАГITOY

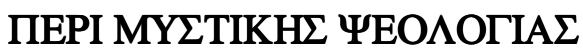

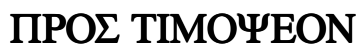

\section{KEФA $\Lambda$ AION Aэ}

$T \Leftrightarrow \omega \mathcal{L} \psi \hat{\varepsilon} \Uparrow \circ \omega \gamma\rangle \phi o \omega$

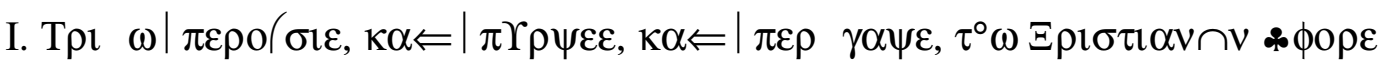

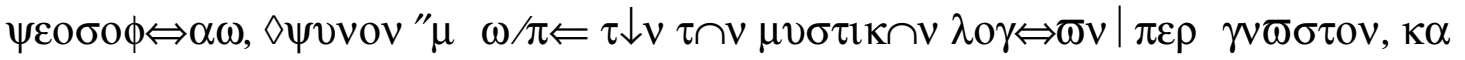
$\Leftarrow$

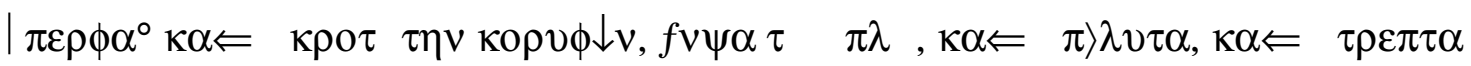
$\tau^{\circ} \omega \psi \varepsilon \delta \lambda \sigma \gamma \Leftrightarrow \alpha \omega \mu v \sigma \tau \rightarrow \rho 1 \alpha, \kappa \alpha \tau \quad \tau \int_{v} \mid \pi \Upsilon \rho \phi \omega \tau o v / \gamma \kappa \varepsilon \kappa \quad \lambda v \pi \tau \alpha l \tau^{\circ} \omega$

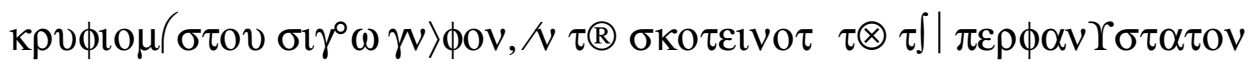

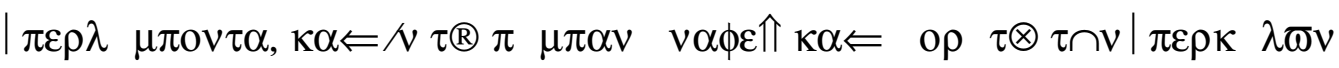

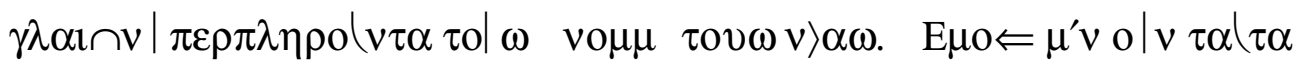
$\left.\left.\eta|\xi \psi \varpi: \sigma| \delta^{\prime}, \notin \phi \Leftrightarrow \lambda \varepsilon \mathrm{T} \imath \mu\right\rangle \psi \varepsilon \varepsilon, \tau \approx \pi \varepsilon \rho \Leftarrow \tau \quad \mu v \sigma \tau \imath \kappa \quad \psi \varepsilon \quad \mu \alpha \tau \alpha \sigma v \nu \tau\right\rangle \nu \otimes \delta 1 \alpha \tau \rho \imath \beta \approx$ $\kappa \alpha \Leftarrow \tau \omega \alpha \Rightarrow \sigma \psi \rightarrow \sigma \varepsilon 1 \omega \quad \pi\rangle \lambda \varepsilon 1 \pi \varepsilon, \kappa \alpha \Leftarrow \tau \quad \omega \operatorname{vo\varepsilon } \rho \quad \omega / \nu \varepsilon \rho \gamma \varepsilon \Leftrightarrow \alpha \omega, \kappa \alpha \Leftarrow \pi \quad \nu \tau \alpha \alpha \Rightarrow$ $\sigma \psi \eta \tau \quad \kappa \alpha \Leftarrow \nu o \eta \tau, \kappa \alpha \Leftarrow \pi \quad \nu \tau \alpha о\lceil\kappa) \nu \tau \alpha \kappa \alpha \Leftarrow) \nu \tau \alpha, \kappa \alpha \Leftarrow \pi \rho \int \omega \tau \downarrow \nu f \nu \sigma \sigma l v, \supset \omega / \phi$ $1 \kappa \tau \uparrow \mathrm{v}$,

$\gamma \nu \oplus \sigma \tau \omega \omega \quad v \alpha \tau \quad \psi \eta \tau \tau \tau o l \mid \pi^{\prime} \rho \pi \quad \sigma \alpha v \circ \circ \sigma \Leftrightarrow \alpha \nu \kappa \alpha \Leftarrow \gamma \cap \sigma \iota v: \tau \approx \gamma \rho / \alpha \nu \tau o l$ $\kappa \alpha \Leftarrow \pi \quad v \tau \sigma \nu \quad \sigma \xi \Upsilon \tau \otimes \kappa \alpha \Leftarrow \pi \mathrm{o} \lambda\left(\tau \otimes \kappa \alpha \psi \alpha \rho \cap \omega / \kappa \sigma \tau \quad \sigma \varepsilon 1 \pi \rho \int \omega \tau \downarrow \nu \mid \pi \varepsilon \rho \mathrm{\sigma} / \sigma 1 \mathrm{ov}\right.$ $\tau o\lfloor\psi \varepsilon \Leftrightarrow \mathrm{ov} \sigma \kappa\rangle \tau \mathrm{O} v \omega \quad \kappa \tau \Uparrow \nu \alpha, \pi \quad v \tau \alpha \quad \phi \varepsilon \lambda \varnothing v \kappa \alpha \Leftarrow / \kappa \pi \quad v \tau \varpi v \quad \pi \mathrm{o} \lambda v \psi \varepsilon \Leftrightarrow \omega$, $v \alpha \xi \psi \rightarrow \sigma \mid$

II. To $\left(\tau \varpi v \delta^{\prime}|\rho \alpha,| \pi \omega \omega \mu \eta \delta \varepsilon \Leftarrow \omega \tau \cap \nu \quad \mu \nu \rightarrow \tau \omega v / \pi \alpha \kappa o(\sigma \mid: \tau o / \tau o v \omega \delta \Upsilon \phi \eta \mu \iota\right.$

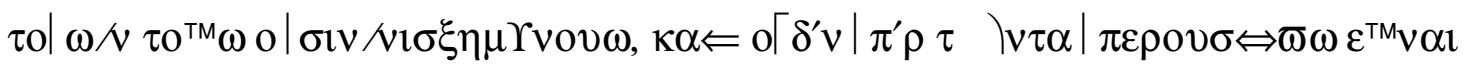

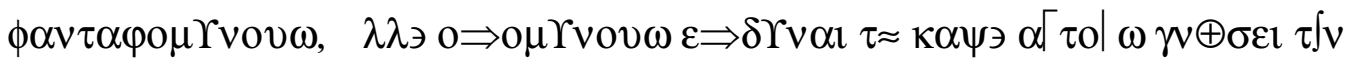

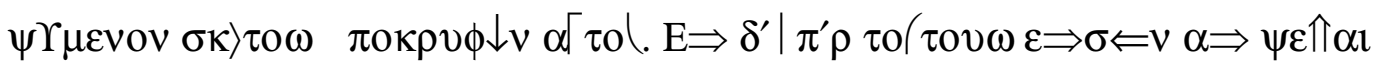
$\mu v \sigma \tau \alpha \gamma \sigma \gamma \Leftrightarrow \alpha l, \tau \Leftrightarrow \quad v \tau \imath \omega \phi \alpha \Leftrightarrow \eta \pi \varepsilon \rho \Leftarrow \tau \cap \nu \mu \lambda \lambda \circ \nu \quad \mu(\sigma \tau \varpi v, \mid \sigma o 1 \tau \downarrow v \pi v \tau \sigma v$ 
$\mid \pi \varepsilon \rho \kappa \varepsilon 1 \mu \Upsilon v \eta \nu \alpha \Rightarrow \tau \Leftrightarrow \alpha \nu \kappa \alpha \Leftarrow / \kappa \tau \cap \nu / \nu \tau o \Uparrow \omega$ o $\mid \sigma \mathrm{vv} / \sigma \xi \tau \sigma v \xi \alpha \rho \alpha \kappa \tau \eta \rho \Leftrightarrow \zeta o v \sigma \mathrm{v}$,

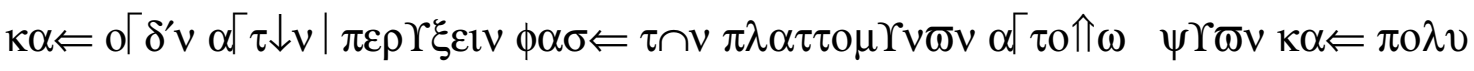

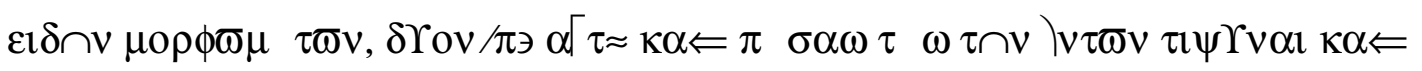

\section{PSEUDO DIONÍSIO AREOPAGITA \\ DA TEOLOGIA MÍSTICA}

\section{Para Timóteo}

\section{CAPÍTULO 1}

O que é a treva divina

I. Trindade Supraessência, Supradivindade e Suprabem, guardiã da sabedoria divina dos cristãos, lança-nos, a partir das palavras místicas, para o cume mais alto, para o supradesconhecido e supraluminoso; aí estão os mistérios simples, acabados e imóveis da teologia; para as supraluminosas e encobertas trevas do silêncio dos iniciados nos mistérios ocultos; para o supraclaríssimo que suprabrilha na máxima escuridão e que, no completamente intangível e invisível, supraplenifica de suprabelos brilhos as inteligências sem olhos. Que eu suplique por mim essas coisas. Mas tu, ó, amado Timóteo, com dedicação intensa às maravilhas místicas, abandona as sensações e as energias intelectuais, todas as coisas percebidas pelos sentidos e pela inteligência, todas as coisas que são e as que não são, e sê elevado inconscientemente para a união, como possível, do que está acima de toda essência e conhecimento; pois pelo êxtase irresistível e livre de todas as coisas e de ti mesmo purificadamente serás libertado para o raio supraessencial da escuridão divina, livrando-te de todas as coisas e de tudo o que é simples.

II. Mas veja que ninguém dos profanos ouça destas coisas; refiro-me a esses que se detêm nas coisas que existem e que se gloriam em não existir nada supraessencialmente acima dos seres, mas pensam saber pelo seu próprio conhecimento o que coloca para a treva o seu secreto. Se os sacerdotes divinos estão acima desses, o que dizer contra os mais profanos, os quais distinguem a causa suprafundamental dos últimos entre os que 
existem, e afirmam não estar ela acima das ateias figuras de variados tipos moldadas por eles. É preciso sobre ela colocar e afirmar todas as teses a respeito dos seres,

$\kappa \alpha \tau \alpha \phi \quad \sigma \kappa \varepsilon \imath \nu \psi \Upsilon \sigma \varepsilon \imath \omega, \supset \omega \pi \quad \nu \tau \sigma \nu \alpha \Rightarrow \tau \Leftrightarrow \&, \kappa \alpha \Leftarrow \pi \quad \sigma \alpha \omega \alpha\lceil\tau \omega \kappa \nu \rho \imath \oplus \tau \varepsilon \rho \circ \nu$

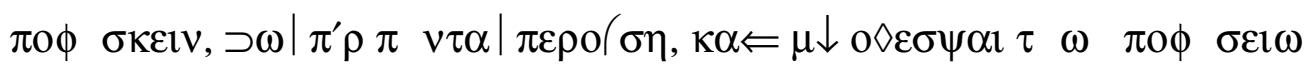

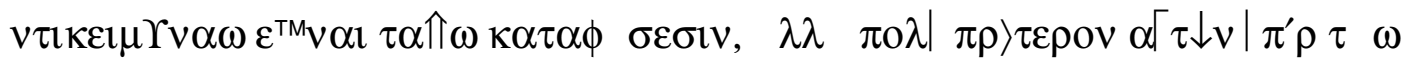
$\sigma \tau \varepsilon \rho \rightarrow \sigma \varepsilon l \omega \varepsilon^{\mathrm{TM}} \nu \alpha l \tau \downarrow \downarrow \mid \pi^{\prime} \rho \pi \quad \sigma \alpha \nu \kappa \alpha \Leftarrow \phi \alpha \Leftrightarrow \rho \varepsilon \sigma l v \kappa \alpha \Leftarrow \psi \Upsilon \sigma \mathrm{lv} ;$

III.

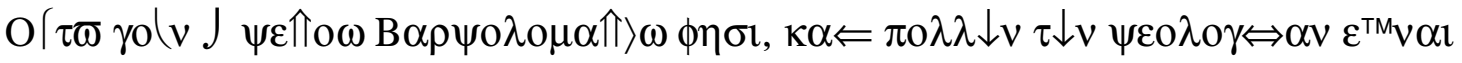
$\kappa \alpha \Leftarrow \lambda \alpha \xi \Leftrightarrow \sigma \tau \eta v: \kappa \alpha \Leftarrow \tau] \mathrm{E}\lceil\alpha \gamma \gamma \Upsilon \lambda \operatorname{lov} \pi \lambda \alpha \tau \mid \kappa \alpha \Leftarrow \mu \Upsilon \gamma \alpha, \kappa \alpha \Leftarrow \alpha \square \psi \imath \omega \sigma v \nu \tau \varepsilon \tau \mu \eta \mu$ rvov.

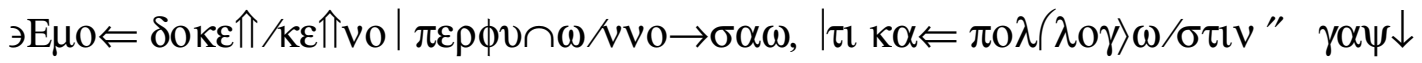

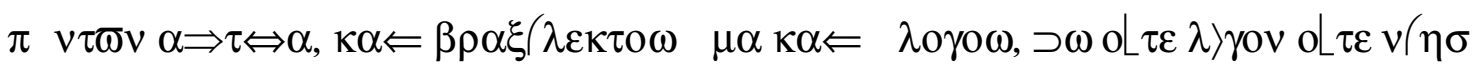
iv

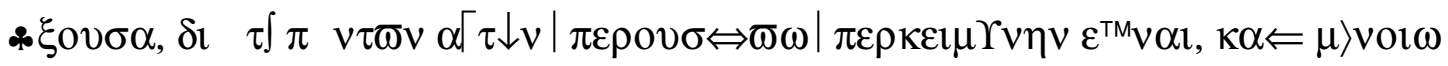
$\pi \varepsilon \rho 1 \kappa \alpha \lambda\left(\pi \tau \varpi \omega, \kappa \alpha \Leftarrow \lambda \eta \psi \cap \omega / \kappa \phi \alpha i v o \mu \Upsilon v \eta \nu \tau o \Uparrow \omega \kappa \alpha \Leftarrow \tau \quad \nu \alpha \gamma^{\circ} \pi \quad v \tau \alpha \kappa \alpha \Leftarrow \tau\right.$

$\kappa \alpha \psi \alpha \rho \quad \delta \mathrm{i} \alpha \beta \alpha \Leftrightarrow v o v \sigma \mathrm{l}, \kappa \alpha \Leftarrow \pi \quad \sigma \alpha \nu \pi \alpha \sigma \cap \nu \quad \gamma \Leftrightarrow \varpi v \quad \kappa \rho о \tau \rightarrow \tau \varpi v \quad v \quad \beta \alpha \sigma \mathrm{lv}$ $|\pi \varepsilon \rho \beta \alpha \Leftrightarrow v o v \sigma \mathrm{l}, \kappa \alpha \Leftarrow \pi \quad v \tau \alpha \psi \varepsilon \uparrow \Uparrow \alpha \cap \tau \alpha, \kappa \alpha \Leftarrow \propto \xi \mathrm{ov \omega}, \kappa \alpha \Leftarrow \lambda\rangle \gamma \mathrm{ov \omega} \mathrm{o}\lceil\rho \alpha v \Leftrightarrow \mathrm{ov \omega}$

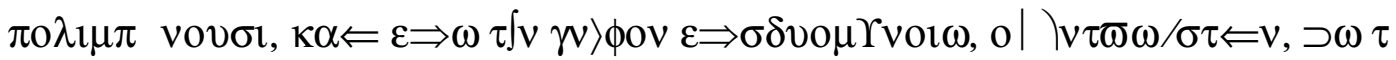

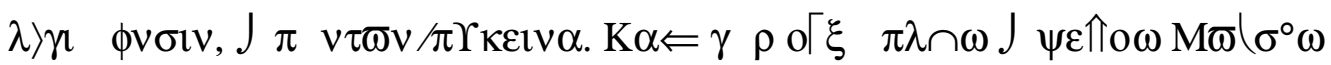

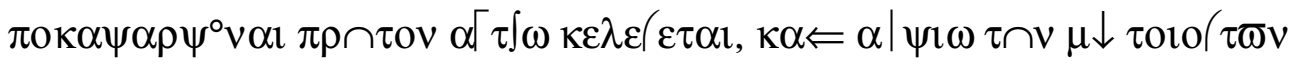

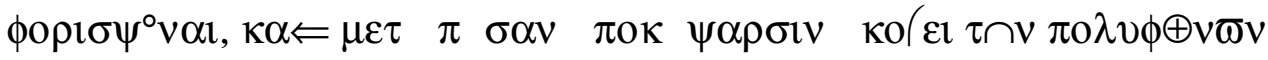
$\sigma \alpha \lambda \pi \Leftrightarrow \gamma \gamma \sigma \nu, J \rho \quad \phi \cap \tau \alpha \pi \circ \lambda \lambda, \kappa \alpha \psi \alpha \rho \quad \omega \pi \alpha \sigma \tau \rho \pi \tau 0 \nu \tau \alpha \kappa \alpha \Leftarrow \pi \mathrm{o} \lambda v \xi(\tau 0 v \omega$

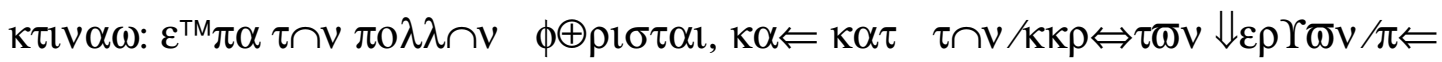

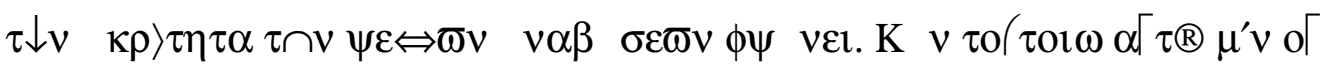




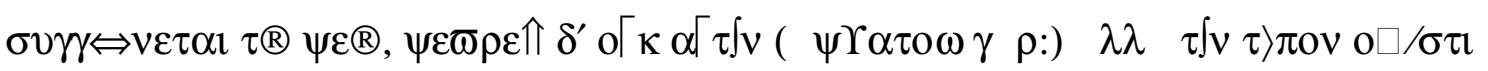

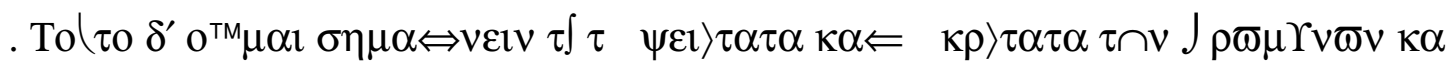

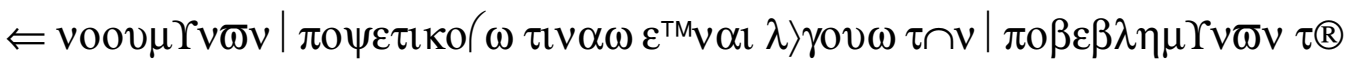

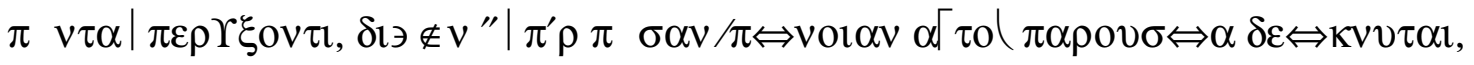

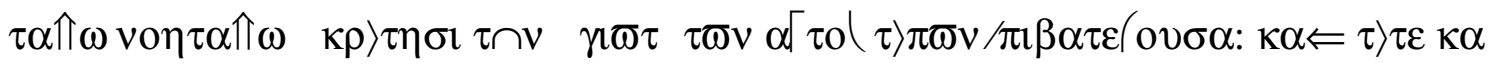

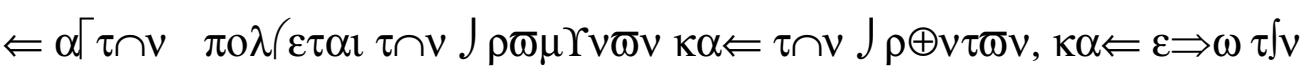

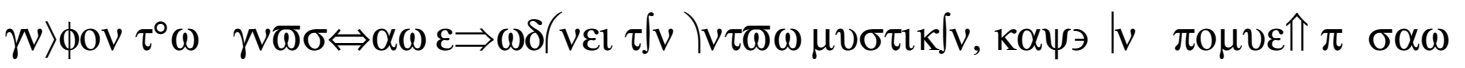

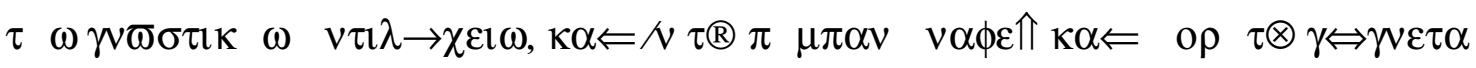
$1, \pi \omega \subset v \tau o\left\lfloor\pi v \tau \varpi v / \pi \Upsilon \kappa \varepsilon l v \alpha, \kappa \alpha \Leftarrow \mathrm{o}\left\lceil\delta \varepsilon v \int \omega \mathrm{o}\lfloor\tau \varepsilon \infty \alpha \nu \tau \mathrm{o} \backslash \mathrm{o} L \tau \varepsilon / \tau \Upsilon \Gamma \rho \nu, \tau \circledR\right.\right.$

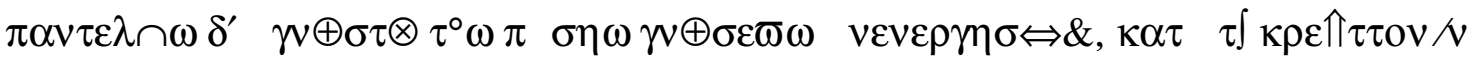
$\mathrm{o} / \mu \varepsilon v o \omega, \kappa \alpha \Leftarrow \tau \circledR \mu \eta \delta^{\prime} v \gamma \nu \oplus \sigma \kappa \varepsilon \imath v, \mid \pi^{\prime} \rho$ volv $\gamma \nu \oplus \sigma \kappa \sigma v$.

como causa de todas as coisas, mas é mais apropriado negar todas essas coisas, como supraessência acima de todas as coisas, e não pensar serem as negações opostas às afirmações, mas muito antes estar ela acima das privações e acima de todo ato de tirar e de colocar.

III. Assim pelo menos disse o divino Bartolomeu ser a teologia numerosa e menos numerosa; e o Evangelho largo e grande e, por outro lado, sintético. Parece-me que pensas extraordinariamente desse, pois a boa causa de todas as coisas é também muitas palavras e ao mesmo tempo breve e sem palavras, como não tendo palavra nem intelecto, por ser o suprafundamento supreessencial de todas as coisas, que se manifesta aberta e verdadeiramente apenas aos que atravessam todas as coisas malditas e puras, elevam-se para toda a subida de todos os santos cumes e abandonam todas as luzes divinas, sons e palavras celestiais, penetrando na treva onde está o que é, como dizem as Escrituras, e mais além de todas as coisas. E assim não simplesmente o divino Moisés foi ele mesmo impelido primeiro a ser purificado e, por outro lado, ser separado das coisas que não essas e, após toda purificação, ouve a polifonia das trombetas, vê brilhando muitas luzes, raios puros e abundantes; fala para ser separado das multidões e, com os sacerdotes escolhidos, alcança o elevadíssimo das subidas divinas. Mesmo com essas coisas, ele não está junto a Deus; vê, porém, não Ele (pois é invisível), mas o lugar onde Ele está. Creio isso sinalizar que as coisas diviníssimas e elevadíssimas das que vemos e pensamos são signos algo hipotéticos das coisas que sugerem do que está 
acima de todas as coisas, pelos quais a sua presença é revelada acima de todo pensamento, subindo aos cumes imaginários dos seus santíssimos lugares; e ele é libertado delas, das coisas que são vistas e das que vêem, e entra para a treva do não saber, para o verdadeiramente místico, onde se anulam todas as contradições conhecíveis e na qual se torna completamente no intangível e invisível, sendo todo do que está além de todas as coisas e não sendo nem dele mesmo nem de outro; no inteiramente desconhecido da ineficácia de todo conhecimento, com o melhor do que é conhecido, e no nada conhecer, conhecendo acima da mente.

\section{KEФA $\Lambda$ AION Bэ}

$\Pi \cap \omega \delta \varepsilon \Uparrow \kappa \alpha \Leftarrow \wedge o\left(\sigma \psi \alpha l, \kappa \alpha \Leftarrow / \mu v o v \omega \quad v \alpha \tau \imath \psi \gamma v \alpha \imath \tau \Theta \pi \quad v \tau \varpi v \alpha \imath \tau \iota \varpi: \kappa \alpha \Leftarrow / \pi^{\prime} \rho\right.$ $\pi v \tau \alpha$.

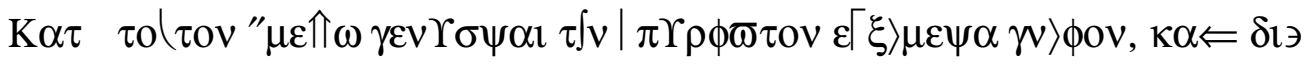
$\beta \lambda \varepsilon \chi \Leftrightarrow \alpha \omega \kappa \alpha \Leftarrow \gamma \nu \sigma \sigma \Leftrightarrow \alpha \omega \Rightarrow \delta \varepsilon \Uparrow \nu, \kappa \alpha \Leftarrow \gamma / \cap v \alpha \mathrm{l} \tau|| \pi^{\prime} \rho \psi \Upsilon \alpha \nu \kappa \alpha \Leftarrow \gamma \nu \cap \sigma \mathrm{l} v \alpha[$ $\tau \int \tau \int$

$\left.\mu \downarrow \Rightarrow \delta \varepsilon \Uparrow \nu \mu \eta \delta^{\prime} \gamma / \cap v \alpha l: \tau o(\tau o \gamma \rho / \sigma \tau l \tau\rfloor\right) \nu \tau \sigma \omega \Rightarrow \delta \varepsilon \Uparrow \nu \kappa \alpha \Leftarrow \gamma \sim \vee v \alpha l, \kappa \alpha \Leftarrow \tau \int_{\nu}$

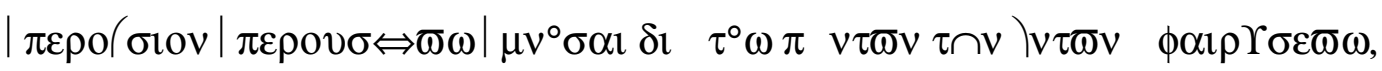
$\not \subset \sigma \pi \varepsilon \rho$ o $\downarrow \alpha\left\lceil\tau o \phi v^{\prime} \omega \quad \gamma \alpha \lambda \mu \alpha \pi \mathrm{olo} \backslash \nu \tau \varepsilon \omega, / \varphi \alpha 1 \rho \mathrm{o} \backslash \nu \tau \varepsilon \omega \pi \quad \nu \tau \alpha \tau\right.$

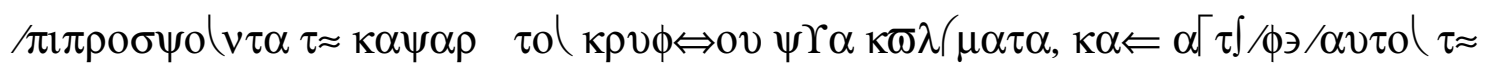

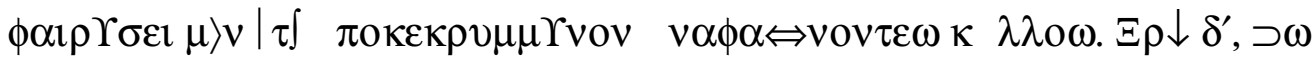

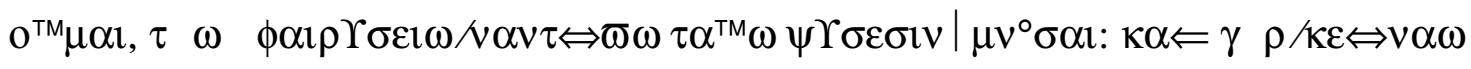

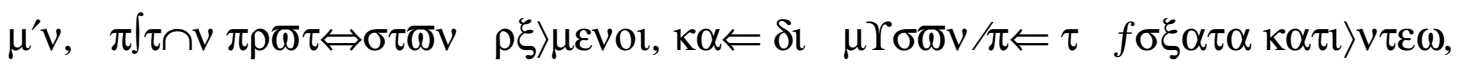
$/ \tau \Leftrightarrow \psi \varepsilon \mu \varepsilon v: N \tau \alpha\left\lceil\psi \alpha \delta^{\prime}, \quad \pi \int \tau \cap v / \sigma \xi \quad \tau \sigma \nu / \pi \Leftarrow \tau \quad \rho \xi_{1 \kappa} \oplus \mu \alpha \tau \alpha \tau \quad \omega\right.$

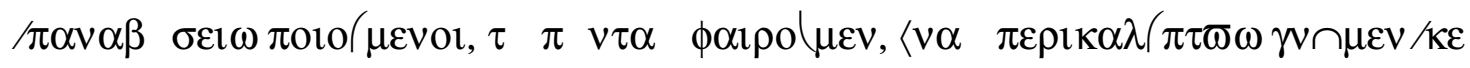

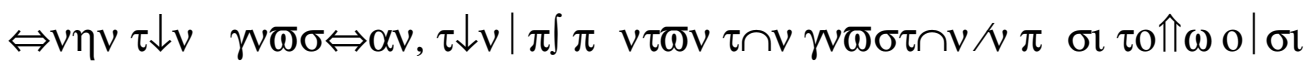

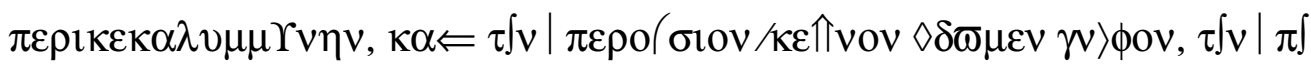
$\pi \alpha \nu \tau \int \omega \tau \mathrm{o} \backslash \mathcal{N} \tau \mathrm{o} \Uparrow \omega \mathrm{o}\left|\sigma \mathrm{l} \phi \omega \tau \int \omega \quad \pi \mathrm{o \kappa} \rho \nu \pi \tau\right\rangle \mu \varepsilon v \mathrm{v}$. 


\section{KEФA $\Lambda$ AION Гэ}

$T \Leftrightarrow v \varepsilon \omega o \downarrow \kappa \alpha \tau \alpha \phi \alpha \tau \imath \kappa \alpha \Leftarrow \psi \varepsilon \delta \lambda o \gamma \Leftrightarrow \alpha l, \tau \Leftrightarrow v \varepsilon \omega \alpha \downarrow \downarrow \quad \pi o \phi \alpha \tau \imath \kappa \alpha \Leftrightarrow$.

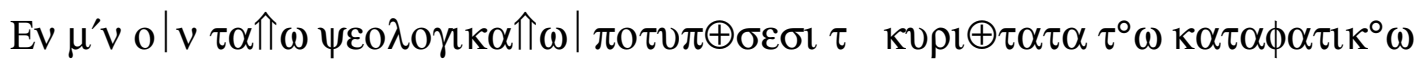
$\psi \varepsilon \sigma \lambda \mathrm{o} \gamma \Leftrightarrow \alpha \omega \mid \mu \nu \rightarrow \sigma \alpha \mu \varepsilon v \pi \cap \omega^{\prime \prime} \psi \varepsilon \Leftrightarrow \alpha \kappa \alpha \Leftarrow \gamma \alpha \psi \downarrow \phi(\sigma l \omega, / \nu 1 \kappa \downarrow \lambda r \gamma \varepsilon \tau \alpha l, \pi \cap \omega$

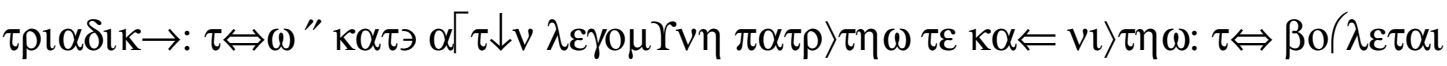

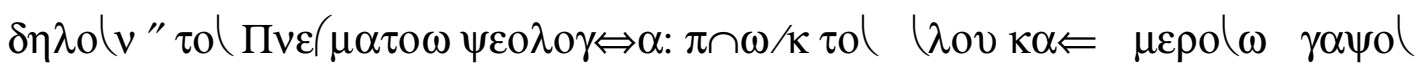

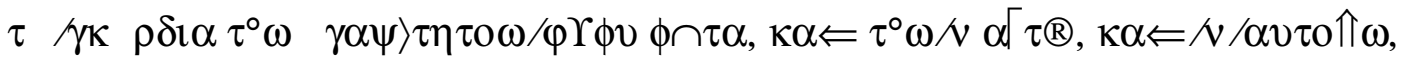
$\kappa \alpha \Leftarrow N \quad \lambda \lambda \rightarrow \lambda \mathrm{ol} \omega \sigma v v \alpha \Uparrow \delta \Leftrightarrow \mathrm{ov} \tau \approx \quad \nu \alpha \beta \lambda \alpha \sigma \tau \rightarrow \sigma \varepsilon 1 \mu \mathrm{ov}^{\circ} \omega \quad \pi \mathrm{o} \mu \varepsilon \mu \Gamma \nu \eta \kappa \varepsilon v$

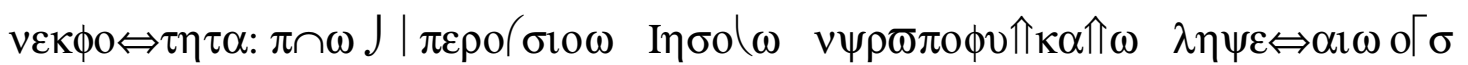

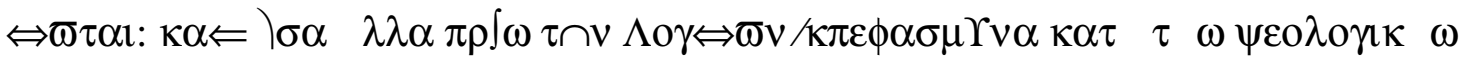
$|\pi \mathrm{o} \tau v \pi \oplus \sigma \varepsilon \mathrm{\omega} \omega| \mu v \varepsilon \Uparrow \tau \alpha \mathrm{l} . \quad$ Ev $\delta^{\prime} \tau \AA \Pi \varepsilon \rho \Leftarrow \psi \varepsilon \Leftrightarrow \varpi v / v o \mu \quad \tau \varpi v, \pi \cap \omega \quad \gamma \alpha \psi \int \omega$ $|v o \mu \zeta \varepsilon \tau \alpha l, \pi \cap \omega \subset v, \pi \cap \omega \zeta \varpi \downarrow \kappa \alpha \Leftarrow \sigma o \phi \Leftrightarrow \alpha, \kappa \alpha \Leftarrow \delta / v \alpha \mu \iota \omega, \kappa \alpha \Leftarrow| \sigma \alpha \quad \lambda \lambda \alpha \tau^{\circ} \omega$

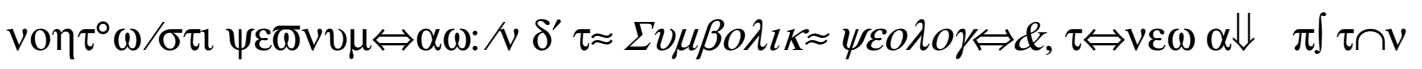
$\alpha \Rightarrow \sigma \psi \eta \tau \cap \nu / \pi \Leftarrow \tau \quad \psi \varepsilon \Uparrow \alpha \mu \varepsilon \tau \varpi v \nu \mu \Leftrightarrow \alpha \mathrm{l}: \tau \Leftrightarrow \nu \varepsilon \omega \quad \alpha \downarrow \psi \varepsilon \Uparrow \alpha \mathrm{l} \mu \mathrm{o} \rho \phi \alpha \Leftarrow, \tau \Leftrightarrow \nu \alpha \tau \quad \psi \varepsilon$ $\Uparrow \alpha$

\section{CAPÍtULO 2}

Como é preciso nos unir e celebrar louvores à causa de todas as coisas; e sobre todas as coisas

De acordo com isso, nós oramos para ser gerada a treva hiper-luminosa e ver a partir da cegueira e da ignorância e conhecer a hiper-visão e conhecimento, Ele, o não ver nem conhecer; pois isso é o ver e conhecer na realidade, e celebrar e hiper-essência hiper-essencialmente através da supressão de todos os seres, como os que fazem imagens naturais, que retiram todos os obstáculos que impedem a visão com pureza do oculto, e revelando por si mesma, pela supressão somente, a beleza escondida. Mas é preciso, como penso, celebrar as supressões contrariamente às teses; e nós colocamos estas, começando das primeiras e, pelas do meio, descendo até as últimas; lá, fazendo as ascensões das últimas até as primordiais, suprimimos todas as coisas, a fim de que desveladamente conheçamos aquele desconhecido, que está oculto sob todas as coisas conhecíveis em todas as coisas que existem, e conheçamos aquela treva hiper-essencial, que está escondida sob toda luz nos que existem. 


\section{CAPITULO 3}

Quais são as divinas afirmações, quais as negações

Assim, nos Esboços teológicos, celebramos as superioridades das teologias afirmativas, como a natureza divina e boa é dita singular e como é trina. O que é dito paternidade e filiação segundo ela; o que a teologia do Espírito quer mostrar; como do bem material e indivisível saem as luzes íntimas da bondade e permanecem indivisíveis nele e nelas mesmas e umas nas outras, a partir do repouso e do renascimento coeterno; como o supraessencial Jesus se fez essência verdadeiramente humana; e quantas outras coisas expressas pelas Escrituras foram celebradas segundo os Esboços teológicos. Em Dos nomes divinos, como o bem é chamado, como o que é, como vida, sabedoria e poder, e quantas outras coisas do que se pode pensar que são denominações divinas; na Teologia simbólica, quais as divinas metonímias, a partir das coisas sensíveis, quais as

$\sigma \xi \rightarrow \mu \alpha \tau \alpha, \kappa \alpha \Leftarrow \mu \Upsilon \rho \eta, \kappa \alpha \Leftarrow) \rho \gamma \alpha \nu \alpha, \tau \Leftrightarrow \nu \varepsilon \omega \mathrm{o} \downarrow \psi \varepsilon \varepsilon \Uparrow o 1 \tau\rangle \pi \mathrm{ol}, \kappa \alpha \Leftarrow \kappa\rangle \sigma \mu \mathrm{ol}, \tau \Leftrightarrow \nu \varepsilon$

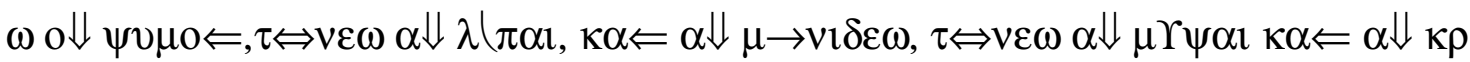
$\alpha 1 \pi \lambda \alpha l, \tau \Leftrightarrow v \varepsilon \omega$ o $\downarrow) \rho \kappa о 1$, $\kappa \alpha \Leftarrow \tau \Leftrightarrow v \varepsilon \omega \alpha \Downarrow \quad \rho \alpha \Leftarrow, \tau \Leftrightarrow v \varepsilon \omega \mathrm{o} \downarrow|\pi v o 1, \kappa \alpha \Leftarrow \tau \Leftrightarrow v \varepsilon \omega \alpha \downarrow / \gamma \rho \eta \gamma\rangle \rho \sigma \varepsilon 1 \omega, \kappa \alpha \Leftarrow \mid \sigma \alpha$

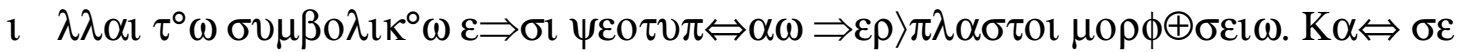
o $\diamond \mu \alpha \imath$

$\sigma v v \varepsilon \varpi \rho \alpha \kappa) v \alpha l, \pi \cap \omega \pi \mathrm{o} \lambda v \lambda \mathrm{o} \oplus \tau \varepsilon \rho \alpha \mu \quad \lambda \lambda\rangle \nu / \sigma \tau \tau \tau \quad f \sigma \xi \alpha \tau \alpha \tau \cap \nu \tau \rho \oplus \pi \varpi v:$ $\kappa \alpha \Leftarrow \gamma \rho \xi \rho^{\circ} v \tau \omega \psi \varepsilon \sigma \lambda \sigma \gamma \kappa \omega|\pi 0 \tau v \pi \oplus \sigma \varepsilon i \omega, \kappa \alpha \Leftarrow \tau \downarrow \nu \tau \cap \nu \psi \varepsilon \Leftrightarrow \varpi v| v o \mu \quad \tau \varpi v$

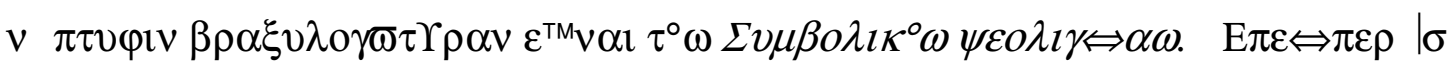

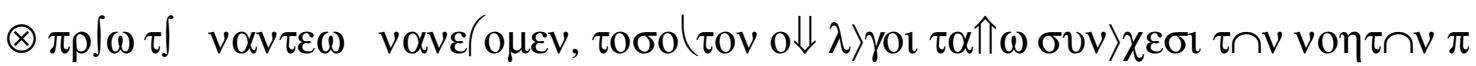

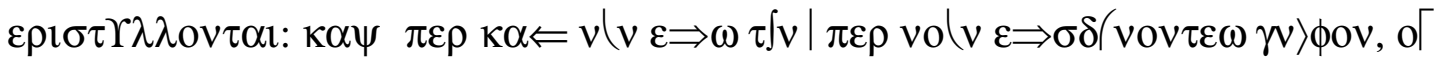

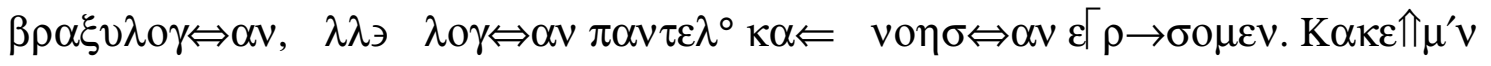
$\left.\left.\pi \int \tau o l \quad v \sigma \pi \rho \int \omega \tau \quad f \sigma \xi \alpha \tau \alpha \kappa \alpha \tau \varnothing \varnothing v \int \lambda\right) \gamma o \omega, \kappa \alpha \tau \quad \tau \int \pi \circ \sigma \int \nu \tau^{\circ} \omega \kappa \alpha \psi\right\rangle \delta o v$,

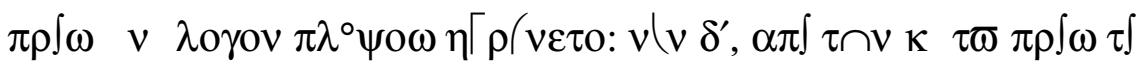
$\left|\pi \varepsilon \rho \kappa \varepsilon \Leftrightarrow \mu \varepsilon v o v \quad v i \varnothing v, \kappa \alpha \tau \quad \tau \int \mu \Upsilon \tau \rho o v \tau^{\circ} \omega \quad v\right\rangle \delta o v \sigma v \sigma \tau \Upsilon \lambda \lambda \varepsilon \tau \alpha l, \kappa \alpha \Leftarrow \mu \varepsilon \tau$ 


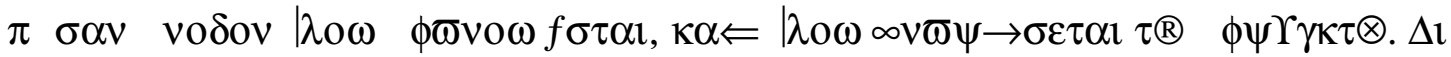

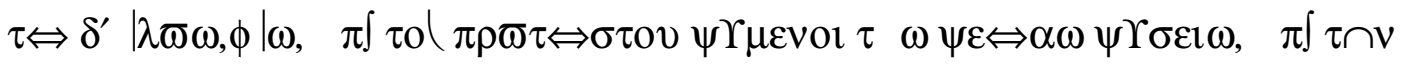
$/ \sigma \xi \quad \tau \varpi \nu \quad \rho \xi\rangle \mu \varepsilon \psi \alpha \tau^{\circ} \omega \psi \varepsilon \Leftrightarrow \alpha \omega \quad \phi \alpha \imath \rho \Upsilon \sigma \varepsilon \omega \omega: \quad$ O $\tau 1, \tau \int \mid \pi^{\prime} \rho \pi \quad \sigma \alpha \nu \tau \imath \psi \Upsilon \nu \tau \alpha \omega$

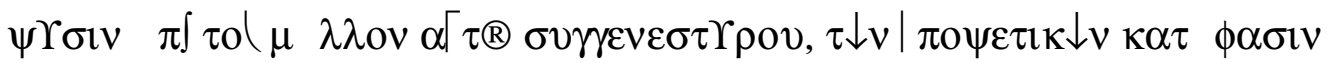
$\xi \rho^{\circ} v \tau \imath \psi \Upsilon v \alpha \mathrm{l}: \tau \int \delta^{\prime} \mid \pi^{\prime} \rho \pi \quad \sigma \alpha v \quad \phi \alpha \Leftrightarrow \rho \varepsilon \sigma \mathrm{lv} \quad \phi \alpha \mathrm{l} \rho \mathrm{l}\left(v \tau \alpha \omega, \quad \pi \int \tau \cap v \mu \lambda \lambda \mathrm{ov}\right.$

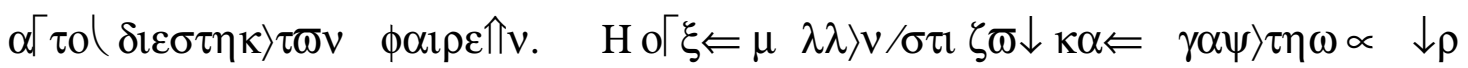

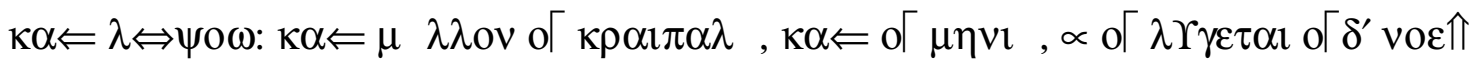
$\tau \alpha \mathrm{l}:$

\section{$\operatorname{KE} \Phi A \Lambda A I O N ~ \Delta \ni$}

$O \tau \iota \propto / \delta^{\prime} v \tau \cap \nu \alpha \Rightarrow \sigma \psi \eta \tau \cap \nu / \pi \alpha v \tau \int \omega \alpha \Rightarrow \sigma \psi \eta \tau o(\kappa \alpha \psi \ni / \pi \varepsilon \rho o \xi \downarrow \nu \alpha \diamond \tau \iota o \omega$.

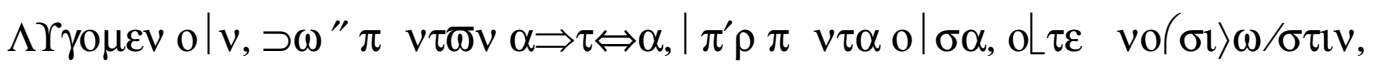

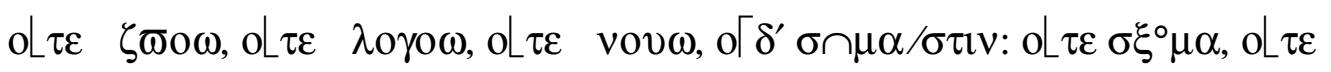

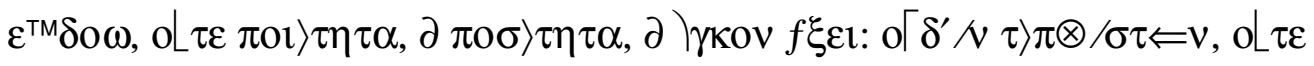

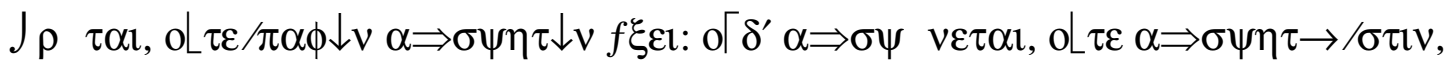

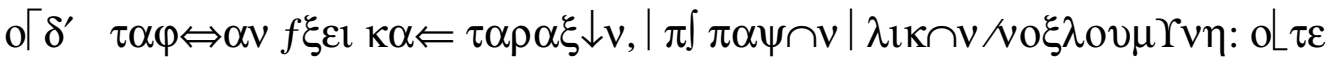

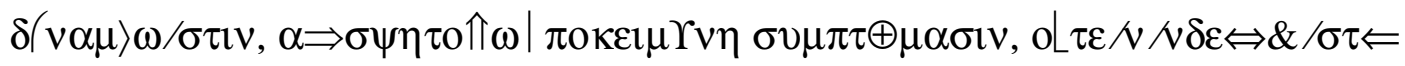

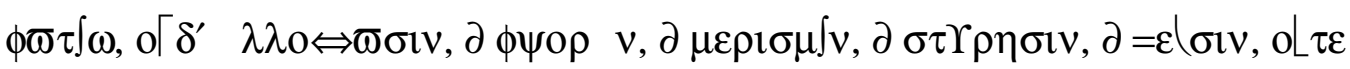
$\lambda \lambda \mathrm{o} \tau \tau \tau \cap \alpha \Rightarrow \sigma \psi \eta \tau \cap \nu, \mathrm{o}\llcorner\varepsilon \varepsilon / \sigma \tau \Leftrightarrow \nu, \mathrm{o}\lfloor\tau \varepsilon f \xi \varepsilon l$.

formas divinas, quais as divinas figuras, partes, instrumentos, quais os lugares divinos, os mundos, quais os desejos, quais as penas, as cóleras, quais as perturbações e as tonturas, quais os juramentos, quais as orações, quais os sonos, quais as vigílias e quantas outras coisas simbólicas são santas modelagens com formas dos tipos divinos. E creio te ter feito ver como os últimos são mais prolixos do que os primeiros; pois era preciso ser a explicação para os Esboços teológicos e para Dos nomes divinos mais lacônica do que a da Teologia simbólica. Quanto nos levantamos, assim as palavras com as visões das coisas pensáveis se fecham. Como também agora, penetrando a treva acima do intelecto, não encontraremos discursos breves, mas a ausência por completo da razão e das palavras. $\mathrm{O}$ discurso procedia do mais alto para baixo, de acordo com a magnitude do caminho de descida, tornando-se maior em proporção. Agora, porém, 
subindo para o suprafundamento, segundo a medida da subida, depois de toda a ascensão haverá a ausência completa de sons, e completamente estaremos unidos ao inefável. Por que, afirmas, a partir do princípio fizemos as afirmações divinas e dos últimos começamos as negações? É que, fazendo afirmações sobre o que está acima de todas as coisas, é preciso fazer afirmações hipotéticas. Mas, negando o que está acima de toda negação, é preciso negar o que lhe é mais distante. Não é Ele mais vida e bondade do que ar e pedra? E não é mais embriaguez ou ira do que não ser dito ou ser pensado?

\section{CAPÍTULO 4}

Por que a causa transcendente do sensível não é nada dos sensíveis

Dizemos, então, como a causa de todas as coisas, essência acima de todas as coisas, não é nenhuma substância, nem um vivente, nem uma razão, nem inteligência, nem corpo, nem tem maneira de ser, nem imagem, nem qualidade ou quantidade ou volume; nem está em um lugar, nem vê nem tem toque sensível; nem sente nem é sensível, nem tem desordem e perturbação, nem é molestada pelas paixões corporais; nem é sem força, nem colocada sob os sintomas sensíveis, nem na insuficiência é luz, nem mudança, ou corrupção, ou partilha, ou privação ou fluir, nem outro algo das coisas sensíveis.

\section{KEФA\AION Еэ}

\section{$O \tau \iota$ o/ $\delta^{\prime} v \tau \cap v v o \eta \tau \cap v / \pi \alpha v \tau / \omega v o \eta \tau o(\kappa \alpha \psi \ni / \pi \varepsilon \rho o \xi \downarrow \downarrow \nu \alpha \diamond \tau \iota o \omega$,}

$\mathrm{A}\left|\psi \imath \omega \delta^{\prime} \quad v \imath\right\rangle \nu \tau \varepsilon \omega \lambda \Upsilon \gamma \gamma \sigma \mu \varepsilon v, \supset \omega \mathrm{o} L \tau \varepsilon \chi v \xi \rightarrow / \sigma \tau \imath \nu, \mathrm{o} L \tau \varepsilon$ vo $\langle\omega: \mathrm{o} L \tau \varepsilon \phi \alpha \nu \tau \alpha \sigma \Leftrightarrow \alpha \nu, \propto$ $\left.\delta\rangle \varphi \alpha v, \propto \lambda\rangle \gamma \circ v, \propto v\rangle \eta \sigma \mathrm{lv} f \xi \varepsilon \mathrm{l}: \mathrm{o}\left\lceil\delta^{\prime} \lambda\right\rangle \gamma \mathrm{\gamma} \omega / \sigma \tau \models v, \mathrm{o} L \tau \varepsilon v\right\rangle \eta \sigma \mathrm{l} \omega: \mathrm{o}\left\lceil\delta^{\prime} \lambda \Upsilon \gamma \varepsilon \tau \alpha \mathrm{l} \mathrm{o}\lfloor\tau \varepsilon v\right.$

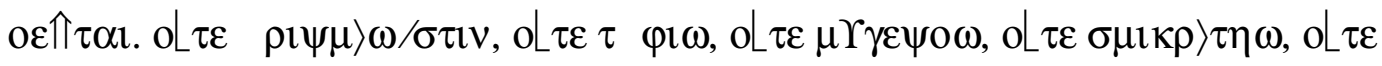

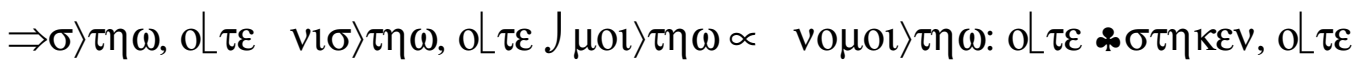

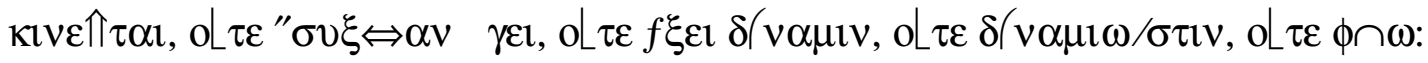

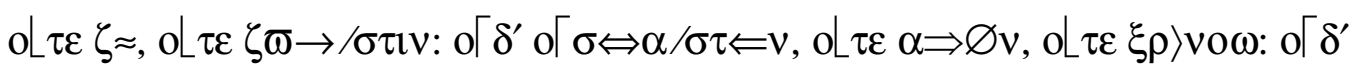




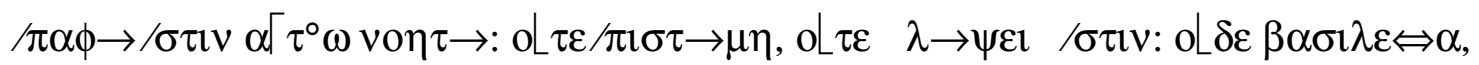
$\mathrm{o}\left\lfloor\tau \varepsilon \sigma o \phi \Leftrightarrow \alpha: \mathrm{o} L \delta \varepsilon \vee v, \mathrm{o}\left\lceil\delta^{\prime} N\right\rangle \tau \eta \omega, \mathrm{o}\left\lceil\delta^{\prime} \psi \varepsilon\right\rangle \tau \eta \omega, \propto \quad \gamma \alpha \psi\right\rangle \tau \eta \omega, \mathrm{o}\left\lceil\delta^{\prime} \pi v \varepsilon \mid \mu \quad / \sigma \tau \iota \nu \supset \omega\right.$ " $\mu \alpha \omega \varepsilon \Rightarrow \delta \Upsilon v \alpha \mathrm{l}: \mathrm{o}\lfloor\tau \varepsilon v \imath\rangle \tau \eta \omega, \mathrm{o}\lfloor\tau \varepsilon \pi \alpha \tau \rho\rangle \tau \eta \omega, \mathrm{o}\left\lfloor\delta \varepsilon \quad \lambda \lambda \mathrm{o} \tau \mathrm{l} \tau \cap v^{\prime \prime} \mu \Uparrow \nu \propto\right.$

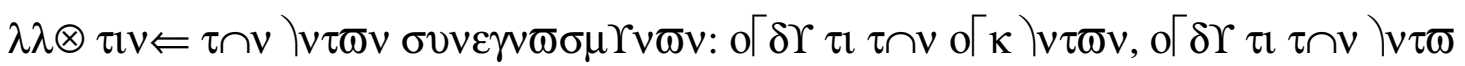

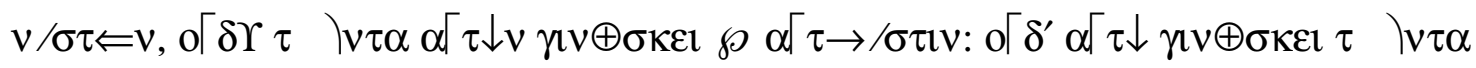

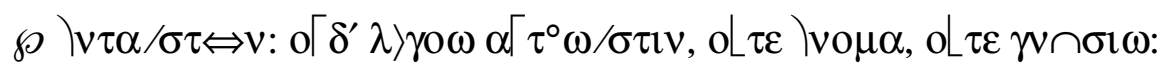

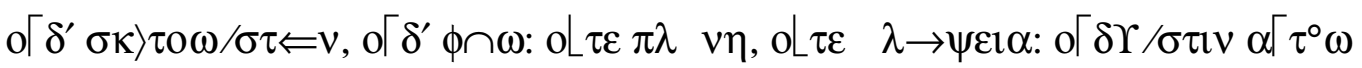

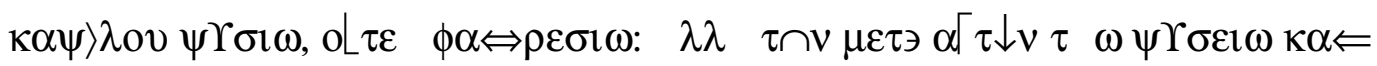

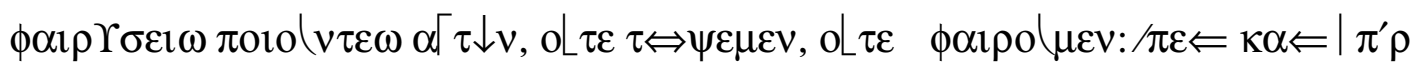
$\pi \quad \sigma \alpha \nu \psi \gamma \operatorname{riv} / \sigma \tau \Leftarrow v^{\prime \prime} \pi \alpha \nu \tau \varepsilon \lambda \downarrow \omega \kappa \alpha \Leftarrow / \nu 1 \alpha \Leftrightarrow \alpha \tau \cap \nu \pi v \tau \sigma \nu \alpha \Rightarrow \tau \Leftrightarrow \alpha, \kappa \alpha \Leftarrow \mid \pi^{\prime} \rho \pi$

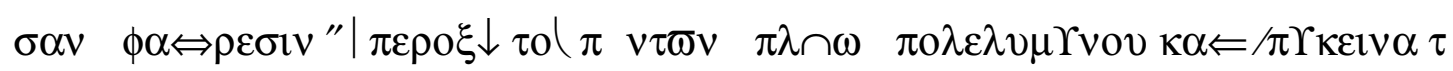
$\cap v$

$\mid \lambda \varpi v$.

\section{CAPÍTULO 5}

Por que a causa do que é pensável não é nada dos pensáveis

De novo, assim, afirmamos, elevando-nos, que não é nem sopro de vida nem intelecto; nem tem imaginação ou opinião ou razão ou o pensar; nem é razão nem pensar; nem afirma nem pensa. Não é nem número nem ordem nem grandeza nem pequenez nem igualdade nem desigualdade nem semelhança nem dessemelhança; nem está fixo nem 
move nem conduz ao repouso nem tem força nem é força nem luz; nem vive nem é vida; nem é essência nem existência nem tempo; dela, nem mesmo é pensável o tocar; nem é ciência nem verdade; nem mesmo reino nem sabedoria; nem mesmo um nem mesmo unidade nem mesmo divindade ou bondade nem mesmo é espírito, como para nós é saber; nem filiação nem paternidade nem outro algo das coisas conhecidas por nós ou por outro algo dos seres; nem é algo das coisas que não são nem é algo das coisas que são, nem as coisas que são a conhecem pelo que é; nem ela conhece as coisas que são pelo que são; nem existe palavra dela nem nome nem conhecimento; nem é escuridão nem luz; nem erro nem verdade; nem há nela uma proposição absoluta nem supressão; mas, das coisas além das afirmações e supressões que a compõem, nem acrescentamos nem suprimimos; uma vez também que a causa perfeita e simples de todas as coisas está sobre toda afirmação, também sobre toda supressão está a proeminência do que está libertado de todas as coisas simplesmente e mais além das coisas todas. 


\section{RESUMO}

Este trabalho sustenta que o teólogo cristão do início do século VI conhecido como Pseudo Dionísio Areopagita exerce profunda influência no pensamento do teólogo e filósofo medieval Tomás de Aquino (1225-1274). Essa influência se dá 
principalmente em dois temas fundamentais da filosofia tomasiana: negatividade e participação. Negatividade diz respeito ao caráter de mistério que envolve as essências mais íntimas dos seres - desde a natureza visível e o homem até o princípio de todas as coisas, Deus - e que, portanto, não são plenamente compreensíveis para o entendimento humano. Participação se refere ao fato de que, por outro lado, o mundo participa do ser de Deus e, por isso, revela traços do divino, ainda que de modo deficiente e remoto. Dada essa influência de Dionísio, Tomás de Aquino não pode ser considerado um pensador racionalista, com respostas definitivas para todos os problemas da existência, como costuma ser visto por epígonos - o que constitui uma deturpação do pensamento tomasiano, marcado pela consciência da insuficiência da razão. Para Tomás, não é possível aos homens ter clareza absoluta sobre qualquer assunto, daí, por exemplo, a necessidade de eles se conduzirem segundo a clássica doutrina cristã da prudência - a virtude de agir corretamente, com base no límpido conhecimento da situação presente. Tendo em vista a negatividade e a participação, para o acesso às realidades mais profundas impõe-se o uso de metáforas, alegorias e símbolos, capazes - de algum modo - de se aproximar do que, afinal, é incognoscível. No que se refere ao conhecimento de Deus, a via de acesso é a mística - entendida como uma experiência com o Absoluto que se dá num plano além da razão, e não aquém -, uma vez que todo discurso racional, afinal, fala mais do homem do que de Deus. Como conclusão, este trabalho propõe que o pensamento negativo do Pseudo Dionísio Areopagita e de Tomás de Aquino precisa ser mais conhecido também por educadores, pois ele permite uma visão diferente da realidade, uma visão menos lógico-racionalista - que tantos problemas tem trazido à sociedade contemporânea - e mais sensível, lúdica e profunda, portanto, mais humana. No anexo, é apresentada a tradução, direta do original grego, do livro Da teologia mística, do Pseudo Dionísio Areopagita.

\section{PALAVRAS-CHAVE}

PSEUDO DIONÍSIO AREOPAGITA - TOMÁS DE AQUINO - NEGATIVIDADE PARTICIPAÇÃO - PRUDÊNCIA - CRISTIANISMO - FILOSOFIA CRISTÃ MÍSTICA 


\begin{abstract}
This dissertation argues that the Christian theologian of the early sixth century known as Pseudo-Dionysius Areopagite exerts profound influence on the thought of medieval theologian and philosopher Thomas Aquinas (1225-1274). This influence is mainly on two major topics of Aquinas' philosophy: negativity and participation.
\end{abstract}


Negativity means the character of mystery that involves the most intimate essence of beings - from the natural world and man to the cause of all things, God - and therefore not fully comprehensible to human understanding. Participation refers to the fact that, on the other hand, the world participates in the being of God and, therefore, shows traces of the divine, even in a poor and remote way. Given the influence of Dionysius, Aquinas can not be regarded as a rationalist thinker, with definitive answers to all problems of existence, as is often seen by followers - which is a perversion of Aquinas's thought, marked by awareness of the insufficiency of reason. For Aquinas, it is not possible for men to have absolute clarity on any issue, then, for example, requiring them to conduct themselves according to the classical Christian doctrine of prudence - the virtue of doing right, based on clear understanding of the current situation. Given the negativity and participation, accessing deeper realities requires the use of metaphors, allegories and symbols, which are able - somehow - to get closer to that, after all, is unknowable. With regard to knowledge of God, the way of access is the mystique - understood as an experience of the Absolute that is given beyond reason, and not short -, since all rational discourse, after all, speaks more about man than about God. In conclusion, this study suggests that the negative thought of Pseudo-Dionysius Areopagite and Thomas Aquinas should be more well known by educators, because it allows a different view of reality, less logical-rationalist - that has brought many problems to contemporary society - and more sensitive, playful and profound, therefore, more human. The annex includes a translation directly from the original Greek of The mystical theology, by Pseudo-Dionysius Areopagite.

\section{KEYWORDS}

PSEUDO-DIONYSIUS AREOPAGITE - THOMAS AQUINAS - NEGATIVITY PARTICIPATION - PRUDENCE - CHRISTIANITY - CHRISTIAN PHILOSOPHY MYSTIQUE 